\title{
The Booker Prize and the Legacy of Empire
}

$$
\text { by }
$$

Luke Strongman

A thesis submitted in fulfilment of the requirements for the degree of Doctor of Philosophy in the University of Canterbury 


\section{Acknowledgments:}

Thanks are due to the following people:

My family: Ken Strongman, Thelma Strongman, Lara Strongman, Neil Semple.

My extended relations: Averil Overton, Fleur Bathurst, Kate Bathurst.

My colleagues, teachers, advisors, and critics: Patrick Evans, John Newton, Anna

Smith, Howard McNaughton, Bill Walker, Kim Worthington, Stuart Murray, Denis

Walker, Rob Jackaman, Phil Wise, Christina Stachurski, Greg O'Brien, Cassandra

Fusco, Andrei Baltakmans, Tony Lee.

My friends: Robin Neate, Matthew Davie, David and Helen Cameron, Margaret Collier. A sincere thank you to Mark Williams for his constant encouragement and support. 


\begin{abstract}
This thesis is about the Booker Prize-the London-based literary award given annually to "the best novel written in English" chosen from writers from countries which are part of or have been part of the British Commonwealth. The approach to the Prize is thematically but not chronologically historical, spanning twenty-six years of award-winning novels from the Prize's inauguration in 1969 to a cut-off point of 1995 . The twenty-nine novels which have won or shared the Prize in this period are examined within a theoretical framework intended to map out the literary terrain which the novels inhabit. More specifically, the thesis is arranged in chapters which explore individually themes that occur within the larger narrative that is formed by this body of novels. The chapters, which are prefaced with thematic introductions and framed by theoretical commentary, explore aspects of the cultures, social trends, and movements that the novels invoke collectively, spanning the stages of British Empire perceived by their authors over the last three decades. Individually and collectively the novels provide a reflection, often in terms of more than a single static image, of British imperial culture after empire, contesting, and reinterpreting perceptions of the historical moment of the British Empire and its legacy in contemporary culture.

It is my thesis that the body of Booker Prize winning novels from 1969 to 1995 narrates the ending of British Empire and the emergence of different cultural formations in its aftermath. This idea is pursued in the seven chapters of the thesis which discretely explore groups of novels which deal with aspects of the transition from empire to a post-imperial culture-the stages from early imperial expansion, to colonisation, to retrenchment, decolonisation and post-colonial pessimism, to the emergence of tribal nationalisms and postimperial nation-states in the aftermath of empire. Throughout this thesis the focus is primarily literary and contingently cultural.
\end{abstract}




\section{Table of Contents}

\section{Introduction}

Chapter One: The Crystal Palace: Novels of the Raj

1. Anglo-India: Nostalgia for the Raj

2. A Minor Victory: J. G. Farrell's The Siege of Krishnapur, 1973

3. India Revisited: Ruth Prawer Jhabvala's Heat and Dust, 1975

4. Anglo-India-Together and Alone: Paul Scott's Staying On, 1978

5. Conclusion: "Orientalism" and inversions of "Self"

Chapter Two: Narratives of Enlightenment and European Expansionism

1. Introduction: The Enlightenment

2. Liberation from History: John Berger's G., 1972

3. Empire at Sea: William Golding's Rites of Passage, 1980

4. Deeds of Empire: Barry Unsworth's Sacred Hunger, 1992

5. Oskar Schindler: Thomas Keneally's Schindler's Ark, 1982

6. Anthem for Doomed Youth: Pat Barker's The Ghost Road, 1995

7. Conclusion: European Expansionism

\section{Chapter Three: Post-colonial Pessimisms}

1. Introduction: Post-colonial Pessimisms

2. Migrant Displacements: V. S. Naipaul's In A Free State, 1971

3. Colonial Dislocations: Nadine Gordimer's The Conservationist, 1974

4. Primordial State: J.M. Coetzee's Life and Times of Michael K, 1983

5. Fantasy and Biculturalism: Keri Hulme's the bone people, 1985

6. Colonial Folly: Peter Carey's Oscar and Lucinda, 1988

7. Conclusion: Visions of Disharmony 
Chapter Four: Post-modernism and History

1. Introduction: The End of the Metanarrative

2. Salman Rushdie, Midnight's Children, and Literary Studies after Empire, 1981

3. A History of the World: Penelope Lively's Moon Tiger, 1987

4. Scholarship and Detective Work: A. S. Byatt's Possession: A Romance, 1990

5. Magic Realism and African Cosmopolitanism: Ben Okri's The Famished Road, 1991

6. Cultural Fragmentations: Michael Ondaatje's The English Patient, 1992

7. Conclusion: Dismantling the Enlightenment

Chapter Five: "Englishness" and "Domestic" Lives

1. Insularities: The Inwardness of Post-Imperial Britain

2. Empire's Others: Bernice Rubens' The Elected Member, 1970

3. Taking a Break: Stanley Middleton's Holiday, 1974

4. Nature or Nurture: David Storey's Saville, 1976

5. Curtain Call: Iris Murdoch's The Sea, The Sea, 1977

6. Empire's Twilight: Kazuo Ishiguro's The Remains of the Day, 1989

7. Conclusion: "Englishness" and "Domestic" Lives

Chapter Six: The English Abroad

1. Excentricity and Eccentricities: The English Abroad

2. Crisis of Commonwealth: P.H. Newby's Something To Answer For, 1969

3. Between Land and Sea: Penelope Fitzgerald's Offshore, 1979

4. Continental Drift: Anita Brookner's Hotel Du Lac, 1984

5. Conclusion: Narratives of Insularity

Chapter Seven: "Post-imperials": The British Post-colonials

1. The British and the New Britain

2. Fakes and Originals: Kingsley Amis's The Old Devils, 1986

3. Towards an Irish Literary Post-modernism: Roddy Doyle's Paddy Clarke Ha Ha Ha, 1993 
4. Grim and Demotic: James Kelman's How Late It Was, How Late, 1994

5. Conclusion: "Post-Imperials": The British Post-colonials

Conclusion: The Booker Prize and the Culture of Post-imperialism Bibliography 


\section{Introduction}

Inaugurated in 1969 as a yearly celebration of the "best novel written in English" authored by a writer from the Commonwealth, over the twenty-six year history of the Booker McConnell Prize and the twenty-nine novels that the prize has singled out for public and critical attention, the "Booker Prize" has become perhaps the most significant annual international award in English letters. The two prizes with which it might be compared are the Nobel Prize for Literature and the Pulitzer Prize. The Booker Prize is distinguished from the first by its yearly focus on a particular novel written in English rather than on a particular author and by its smaller scale, and from the second by its association with England and the Commonwealth rather than with America. However, it is also to be distinguished from a third prize, the Commonwealth Writers' Prize "Best Book Award", by its Anglo-centricity. The Booker Prize is judged by a centralised committee based in London; the judges for the Commonwealth Writers' Prize are appointed regionally, and regional awards are made prior to the award of the overall Prize.

The Booker Prize is sponsored by Booker PLC, an international conglomerate specialising in food and agriculture. During the mid 1960s Booker established a division to purchase the copyright of famous authors who included Agatha Christie and Ian Fleming. This proved profitable and successful for the Booker company and the authors whose copyright they obtained. The chairman of the books division, Charles Tyrell, and the managing director, John Murphy, with the company's chairman, David Powell, aimed to show their appreciation for the success of their authors in the form of support with scholarships and bursaries. Tyrell and Powell were approached by Tom Maschler and Graham C. Greene, then chairman and managing director of Jonathan Cape, who were looking for a sponsor for a major fiction prize that would rival the French Prix Concert. The Publishers' Association supported Maschler, and the Booker Prize was inaugurated in 1969. 
The Prize started at the amount of $\mathfrak{E} 5000$ in 1969 , rose through $\mathfrak{E} 10000$ and $\mathfrak{E} 15000$ to its current value of $£ 20000$ in 1998 . Although arguably the most renowned literary prize in the English-speaking world, the Booker is not the most valuable-the Whitbread, Trask, David Cohen Writer's Prize and the Sunday Express Prize all are worth more than the Booker.

The management of the Prize is carried out by a committee that consists of an author, two publishers (hardback and paperback), a bookseller, a librarian, the chairman of Booker PLC, another senior executive from that company and the Prize's administrator. The administration of the Prize is carried out by Book Trust (called the National Book League until 1986), an independent charitable trust whose aim is to promote reading. Selecting judges is one of the Management Committee's major functions. At the February meeting a standing list of possible judges is proposed, and one of the Committee's first tasks is to find a chairman for the forthcoming year. Three possibilities are normally nominated with the intention of finding a balanced team under each. The team of judges is chosen from a field of disparate although related interests: academics, critics, writers and a reader from the general public. (In the past the organising committee has tried to involve overseas judges, but for reasons of practicality this has usually been decided against.) Five judges are normally chosen.

The largest problem facing the judges lies in the definition of the overall aim of the Prize to find "the best novel of the year". Such a definition is flexible, and each judge will have his or her own interpretation and bring his or her own criteria to the selection of it. The Management Committee's other main task is to amend rules as and when necessary. The Booker Prize is open to citizens of the "former" British Commonwealth, by which is meant the present Commonwealth plus Pakistan, and South Africa. Publishers submit three titles and may submit a further five titles that they want especially to bring to the judges attention. The Booker judges may call in any titles which were not entered or listed but which they feel are of merit. The number of entries approximates between 85 and 105 annually. 
Once the judges are chosen and any of the rules amended, the Management Committee hands the administration of the Prize over to Book Trust. Book Trust is responsible for publicity; the Trust mails entry forms to publishers and announces the Prize in the trade press. Entries start to arrive late April or early May. The closing date for entries is June 30th, extended to July 31 st in special cases. During the third week in August six "frontrunners" are selected by each judge. From the shortlist meetings something like twenty or thirty books emerge from which the winner is ultimately selected. ${ }^{1}$

The novels which win the Booker Prize enjoy widespread public and critical attention within the English-speaking world. Similarly, the focus of literary attention world-wide is in large part directed annually at the qualities of the work selected for the Prize, and thus those qualities which the judging committee seeks to bring to the attention of the reading public and the critical eye. By inference there seem to be two concerns involved in the awarding of the Prize: to direct attention annually at a particular novel and its author; and to attend to the novel as a form and a medium for new voices, styles, and cultures.

The Booker Prize is a crucial prize in English letters because it is perceived as one that from a (former) imperial centre confers literary recognition on novels which reflect and portray the state of culture after empire. This state can be expressed in either of two general ways. Firstly, it can be seen as a post-colonial response in which society is characterised by the attempt to attain independence from the former coloniser or to establish new or hybridised identities separately from the formerly colonising culture. Secondly, it may represent a "post-imperial" response in which the culture of Great Britain is enriched by the disparate ethnicities of its former empire and sets about refashioning its own identity in post-imperial terms. This thesis is concerned with the period after the collapse, at least officially, of the British Empire and traces the changing apprehensions of empire-nostalgia, critique, subversion-noting the emerging signs of post-imperial cultural formations in the body of novels that have won the Prize.

"Post-imperial" here refers to Britain-after empire. It refers to literature which reflects trends in the society of the former imperial nation and is to be distinguished from 
the literature of formerly colonised nations. If post-colonial studies are now concerned with redefining the cultural identities of nations influenced by colonial rule, then the Booker Prize participates in the promotion of the contemporary novel in terms that to some extent agree with that agenda. All of the Booker Prize winning novels have an implied relationship with empire, whether this be writing in the form of counterdiscourse, subscription to imperial rhetoric, nostalgia for empire, or of an articulation of identity in the fluid internationalisms which emerge after empire. This territory is now as much a discursive one as a fixed and demographic or topographical one. As Arif Dirlik has pointed out, "Intellectuals in the flesh may produce the themes that constitute postcolonial discourse, but it is participation in the discourse that defines them as postcolonial intellectuals." 2 In many ways the Booker Prize, awarded in London to novels from former Commonwealth countries including Nigeria, Malaysia and Eire (as well as Britain itself), acknowledges the changed relationship of "Great Britain" towards its former empire and to colonised subjects within Britain-both immigrants and the Irish, Scots, Welsh whose cultures have been long established before. While it is founded, funded, and administered in England and could be said to continue the motives and rhetoric of empire, the Booker has also fostered the movement beyond the old themes of expansion, profit, rule, suppression, and displacement towards a new sense of the energies and relations among various immigrant groups, regions, and peoples within Britain and among its former colonies.

Edward Said writes of the relationship between imperialism and the novel:

I am not trying to say that the novel-or the culture in the broad sense-'caused' imperialism, but that the novel, as a cultural artefact of bourgeois society, and imperialism are unthinkable without each other. Of all the major literary forms; the novel is the most recent, its emergence the most datable, its occurrence the most Western, its normative pattern of social authority the most structured; imperialism 
and the novel fortified each other to such a degree that it is impossible, I would argue, to read one without in some way dealing with the other. ${ }^{2}$

Said's point also applies after empire, during its dismantling. It is not so much that "the Empire is writing back to the imperial centre", as Salman Rushdie has put it, but that the idea of centre and periphery between Great Britain and its colonies is progressively dissolving (although the continued prestige of the London-based Booker Prize remains a tangible measure of the tensions within a literary globalism). In place of an empire centred on a single great city, a multiplicity of metropolitan "centres" appears, each with its own sphere of influence within the wider confluence of globalism and English language usage, and each of which is in turn challenged by those contesting the centreand-periphery model. ${ }^{3}$

Analysis of the Booker Prize winners reminds us that it is no longer useful to conceive of a study of literature from the secure perspective of "centre" and "margin". While the imperial project is usually seen as a rapacious presence, forcing an influence commercially or militarily from "without", the nature of this influence historically is often a process of mutual complicity and entanglement. In spite of its aggressive nature, imperialism was never static or one way and the very act of influencing other nations changed the nature of the influence itself and the dominant power in the exchange. As Arif Dirlik puts it:

One might go far so far as to suggest that, if a crisis in historical consciousness, with all its implications for national and individual identity, is a basic theme of postcoloniality, then the First World itself is postcolonial. To the extent that the Euro-American self-image was shaped by the experience of colonizing the world (since the constitution of the Other is at once the constitution of the Self), the end of colonialism presents the colonizer as much as the colonized with a problem of identity. 4 
The Booker Prize recognises both "post-colonial" and "post-imperial" writing-that from Britain's former colonies and that from within Britain itself. Not all the winning novels are actively engaged in "de-scribing" or dismantling empire, but all are part of the aftertext of empire. "Commonwealth" writers increasingly concern themselves with the re-inscription of new and hybridised identities, amalgamations of indigenous, colonial, and post-colonial influences; the Booker Prize has acknowledged the variety of those reinscriptions in the range of novels it has selected. At the same time the Booker has helped maintain the discrete ties between Commonwealth nations and the once imperial centre, and signalled the continuing commonalities of history and administration among the nations of the former empire.

This thesis undertakes a literary-critical investigation of the twenty-six-year history of the Booker Prize. The approach to the Prize is not chronological but thematic. It is argued that the Booker Prize winning novels collectively provide a form of reference to Britain's post-imperial, and the former empire's post-colonial, development, and that they are indexed to empire's occurence and to its crises of identity.

The Commonwealth of Nations in the 1990s is a very different entity, and has a very different socio-political form, not only from the Victorian empire but also from the Commonwealth of the 1960s and 1970s. As the former colonies and dominions changed, so too did Britain, with a large influx of immigrants from the Commonwealth arriving after the Second World War. While this process of "reverse-colonialism" took place, the empire was shrinking rapidly. In September 1944, British imperial possessions numbered forty states with a total population of 760,774,000 peoples, while by July 1997 there were only twelve British colonial possessions with a total population of 168,000 peoples. As Simon Winchester points out, "It is a grim arithmetic: in a little more than half a century the world's most fabulous empire will have shrunk to one fiftieth of one percent of its former size...." 5 An analysis of the Booker Prize winning novels provides a literary reflection of these changes: both the imperial project of the nineteenth century and its metamorphosis into the Commonwealth, and of the post- 
imperial and post-modern discursive domains of contemporary British culture. It does so from the perspectives of all sides of the imperial process: colonisers, colonised and those who owe something to both.

It is my intention here to provide an analysis of the Booker Prize in terms of its influence on the development of the contemporary novel and the direction of the fields of both "English literatures" and "post-colonial" studies. An analysis of the Booker Prize winners provides a means of interpreting the direction of the contemporary Englishlanguage novel outside the United States in terms of the attempts to understand the processes and after-effects of imperialism, to write, erase, and re-write the text of empire, and to assess the ways in which Great Britain and its relationship with empire have changed. Such an analysis involves questioning the usefulness of the terms postcolonialism, postmodernism and post-imperialism which govern much current critical discourse in this field.

In this thesis the use of the term "post-colonial" is to be understood as meaning a global condition distributed across different nations and cultures in which the traffic from imperial centre to colonial periphery is revised as a much more complex and fluid movement between members of various cultural and national groups, ethnicities, religions and languages. This movement occurs between and across international borders in the process of articulating new cultural identities and collectivities. One of the problems with such a broad conception of "post-colonialism" is that it runs the risk of masking heterogeneities, eliding differences, and collapsing diverse chronologies. It also raises the difficult question of when did post-colonialism begin? This question is unavoidable when considering such a vast topography and chronology as the territory of "after-empire" and they arise among those people who variously identify themselves as British as well as among those who are anti-colonial non-British, and those who claim hybrid identities across cultures in the British diaspora. However, the implied relationship with the metropolitan centre and the process of imperial expansion and collapse remain constant presences in the after-text of empire even if the relationship 
between centre and periphery was a vastly different experience for different nations. Furthermore, as Ella Shohat has claimed:

The vague starting point of the 'post-colonial' makes certain differentiations difficult. It equates early independence won by settlercolonial states, in which Europeans formed their new nation-states in non-European territories at the expense of indigenous populations, with that of nation-states whose indigenous populations struggled for independence against Europe, but won it, for the most part, with the twentieth century collapse of European Empires. ${ }^{7}$

The use of the term post-colonial in this thesis is one that is also understood as containing rather than eliding these differences. It is a term which describes a global condition harbouring a number of differences. Depending on whether one is advancing the view of the British or those who see themselves as different from them, the terms "post-imperial" or "post-colonial" will be employed. In this sense the terms are contemporary metanarratives-large structures of meaning-that contain numerous smaller narratives in terms of the people and nations to which they refer. The terms mark a resistance to postmodernism which argues for the deconstruction of such large organising principles.

There is no common theoretical or critical methodology that might comment on the various readings of the term "post-colonial"; however, both post-modernism and postcolonialism encourage the articulation of difference by focusing on the "minority perspective", the voice of the local within the global, and by entering an "ongoing negotiation that seeks to authorize cultural hybridities that emerge in complex moments of historical transformation", as Homi Bhabha puts it. ${ }^{8}$ Both post-modernism and postcolonialism are preoccupied with the attempt to "legitimate" and position voices from the alteria at the same time as they question the function and meaning of such a process. Both treat all forms of knowledge and discourse as heuristic equals and attempt to dismantle the hieratic codes of colonialism and modernism. Both are amorphous terms 
whose exact meaning changes with voice and context, but here "post-modern" will be used to describe those novels that reflect: stylistic preoccupations in language, a general shift from epistemological questions (What can we know about the world?) to ontological ones (What kinds of worlds are there? How do they differ from one another?), the poststructuralist preoccupation with deferral of meaning and articulation of hybridities, and the absence of metanarrative or of the presence of an overriding metaphysic or ideological intent in language use. However, despite these apparently egalitarian, relativistic, and levelling tendencies, the fact remains that for the colonised and for the coloniser in their post-colonial and post-modern manifestations, the dominant form of discourse remains the English language, a language deeply implicated in imperialism.

The primary significance of post-colonialism with respect to post-modernism in this context is the articulation and exploration of liminality, the tendency to force the West to the limits of its own cultural assumptions and in so doing open up a space in which minority voices may be renegotiated and authorised within a hybrid culture. In the context of hybridity, it is argued that hegemonic discourse carries within itself a rending which allows for strategic subversion and becomes manifest in such diverse articulations as forced assimilation, cultural mimicry, internalised self-rejection, internalised fracture and doubleness, and creative transcendence each with its own degree of resistance. However, this process of deferral of meaning, intrinsic to hybridity and poststructuralism, can never be articulated with completeness; the space opened up by the constant play of meanings and fragmentation of the stable narrative is never closed. The looking "beyond" in post-modern and post-colonial reading of hybridity is always caught between two positions: between present and past, between current urgencies and historical revisionism, between fixed meaning and one that is constantly revised, between the oscillation of signifier and signified. As Homi Bhabha puts it:

The wider significance of the postmodern condition lies in the awareness that the epistemological 'limits' of those ethnocentric ideas are also the enunciative boundaries of a range of dissonant, even 
dissident histories and voices-women, the colonized, minority groups, the bearers of policed sexualities. For the demography of the new internationalism is the history of postcolonial migration, the narratives of cultural and political diaspora, the major social displacements of peasant and aboriginal communities, the poetics of exile, the grim pose of political refugees. It is in this sense that the boundary becomes the place from which something begins its presencing in a movement not dissimilar to the ambulant, ambivalent articulation of the beyond ...9

Bhabha's intention to look "beyond" cannot be achieved unless he abandons the prefix of his "contra-modernity" and the oppositional dialectic it reinforces in favour of a term or hermeneutic which seeks to reposition, relocate, or redefine the theoretical parameters of both modes of discourse. Furthermore, what defines a culture is never finally a difference from another culture but what is necessary to itself, although this is an implicit assumption behind much of the use of the term "post-colonial". Also, as Anne McClintock points out, the prefix "post" reduces the peoples of formerly colonised cultures to a "prepositional" time. Colonialism claims the central place in the narratives of history and is the determining marker, pushing the cultures of the colonised peoples into a prepositional relationship with a eurocentric concept of "post" or "pre" that also precludes their multiplicity. As McClintock puts it, "the world's multitudinous are marked not positively by what distinguishes them but by a subordinate, retrospective relation to linear, European time."10

Furthermore, both post-colonialism and post-modernism are movements which operate diachronically, although much of the "culture" industry which employs them assumes them to be understood synchronically as terms referring to examples of particular cultural forms. They are used to describe the historical developments of a culture through time, but are frequently and mistakenly understood as terms 
characterising broad moments in historical development. Thus the mistake is made in thinking of them as static and as proceeding from some fixed point.

Bhabha's assertion of a space of translation that is opened up within post-colonial, post-modern, or contra-modern societies in which it is possible to overcome the grounds of racial or cultural opposition and reconcile the binary relationship between master and slave, coloniser and colonised, cannot be achieved under the auspices of either postcolonialism or Bhabha's own term, "contra-modernity": both are terms which at their core articulate a difference, a dialectic, or oppositional stance. A non-binary movement across and among cultures is more likely to acknowledge the complex, ambiguous and ongoing processes of hybridisation for the colonising presence as well as for the colonised. But again this deconstruction of identity takes its founding moment in poststructualist analysis rather than political reality. Bhabha indicates something of this dilemma when he writes:

The language of critique is effective not because it keeps forever separate the terms of the master and slave, the mercantilist and the Marxist, but to the extent to which it overcomes the given grounds of opposition and opens up a space of translation: a place of hybridity, figuratively speaking, where the construction of a political object that is new, neither the one nor the other, properly alienates our political expectations, and changes, as it must, the very forms of our recognition of the moment of politics. ${ }^{11}$

This change which forms our "recognition of the moment of politics" is one towards a recognition of the cultural condition "after empire", a condition which attempts to articulate the unnamed "third space" of Bhabha's conceptualisation. This is a condition which both acknowledges the processes of expansion and the dissolution of empire in the course of contemporary nation-formation and which resists the urge to camouflage the continuing presence of the systems of social, economic, and cultural control within the 
discourse of post-empire. Within this framework, as Bill Ashcroft has suggested, the subaltern may speak as an interpolatory agent: "Interpolation describes . . . the process by which the colonised may resist the forces which serve to construct it as other; it describes the access such an 'interpolated' subject has to counter-discursive agency. For this strategy gestures to the capacity to interpose, to intervene, to interject a wide range of counter discursive tactics into the dominant discourse without asserting a unified antiimperial intention, or a separate oppositional purity." 12

The environment of subaltern interpolation displays many of the characteristics of "post-colonialism": a recognition of the "Other"; the subscription of both authorship and authority to marginalised voices; a relativism which places these voices parallel with the histories of writing nationhoods, but is without the baggage of guilt perpetuated by the oppositional dialectic implied in the term. Thus the condition "after empire" reflects and admits the forces of imperialism which have shaped and continue to shape, albeit in altered form, the narration of nations and peoples. While Bhabha's adherence to poststructuralism may have opened up in the discourse of post-colonialism a space of "translation" allowing for the construction of identities that avoid the binarism of coloniser and colonised, his theory fails to grapple with the actual dynamics and power structures that inform his hybrid "space", the global conditions of post-modernity "after empire". As Shaobe Xie puts it:

In deriving its language and conceptual framework from poststructuralism, Bhabha's postcolonial criticism becomes apolitically immersed in discourse on 'hybridity' and 'in-betweeness' outside of global power relations and corresponding political struggles. These blind spots of his theory, however, point not only to the inadequacy of his conceptual framework of analysis, but also to the difficulty of resisting the all-subsuming power of post-modernism itself . . . we have to acknowledge a global predicament that no counterhegemonic 
discourse is innocent of complicity in reaffirming postmodernism's hegemony. ${ }^{13}$

Instead of proposing an alternative term which might compete for the same overlapping meaning as the terms "post-colonialism" and "post-modernism", it is my intention to emphasise the contradictions, complicities and over-simplifications which the use of such binary-laden terms will always hide, and the residual humanism that is the shadow of counter-hegemonic post-colonialism-the belief that deconstruction of the representational hierachies of colonialism is both necessary and good. The problem with Bhabha's empowered space of post-colonial enunciation and transformation is that it is fundamentally a discursive one which is dependent on the engagement of intellectuals in the discourse of post-colonialism, which itself is subject to the deconstructionism of postmodernism, a cultural condition intimately linked to late capitalism. As Dirlik emphasises: "[P]ostcoloniality is designed to avoid making sense of the current crisis and, in the process, to cover up the origins of postcolonial intellectuals in a global capitalism of which they are not so much victims as beneficiaries."14

Such complexities appear to announce the state of the independence of the contemporary novel in English from the paradigm of empire and colony, centre and margin, whilst acknowledging that the exponents and critics of this discourse occupy a part of a new-found power that is complicit more within capitalism than within the boundaries of post-colonialism itself. Yet within their broader themes and terms of reference these histories are shown to be different from one another and go hand in hand with the kinds of identity issues that preoccupy the First World nations who argue for a global post-modernism that subordinates consumers, cultures and critics to the "cultural logic of Late Capitalism", in Frederic Jameson's popular phrase. As Aijaz Ahmad points out:

That one is free to invent oneself and one's community, over and over again, as one goes along, is usually an illusion induced by the 
availability of surpluses - of money-capital or cultural capital, or both. That frenzied and constant refashioning of the Self, through which one merely consumes oneself under the illusion of consuming the world, is a specific mode of postmodern alienation which Bhabha mistakenly calls 'hybridity', 'contingency', 'postcoloniality'. ${ }^{15}$

The Booker novels participate in and reflect the proliferation of "Englishes" after empire, none of which is necessarily defined by a difference from a dominant notion of English culture proper, but rather by the expression of an evolving notion of language, ethnicity, and identity in localised areas that are now far removed from the historical precedent of empire. The articulation of these specific identities and their resistance to assemblage into an overriding narrative of empire signals a complicity with postmodernism. A process of continual interaction and change within a world-wide spread of local Englishes needs to be acknowledged in which, for example, Ben Okri's The Famished Road (1991) may invite meaningful comparison with Roddy Doyle's Paddy Clarke Ha, Ha, Ha (1993). Both novels, by African and Irish cosmopolitans, may be characterised by their acknowledgement of, but wish to separate themselves from, the narrative of empire.

To a large extent, then, English has become a truly international language belonging inevitably to no one centre but rather to a multiplicity of regional foci. However, within this revised sphere of influence, the rhetoric of imperialism and the binary relationship between coloniser and colonised originating in empire is pervasive and continues to exercise a degree of influence over the cultures of its aftermath. The body of works that make up the Booker Prize winners articulates the various tensions along this continuum from the early binary interdependence in empire's genesis through the continued but waning assurances of later empire, to the isolations, both domestic and international, of its aftermath in the "post-colonial" and "post-imperial" literatures, its post-modern preoccupations with narrative, illusion, boundary transgressions and topographies, and finally to the growth of the emergent independent centres of a local and global English, be 
these within or outside of Great Britain. As Said puts it in Culture and Imperialism, "One of imperialism's achievements was to bring the world closer together and, although in the process the separation between Europeans and natives was an insidious and fundamentally unjust one, most of us would now regard the historical experience of empire as a common one." 16 The central point in this is that a coming to terms with culture "after empire" takes into account both the process of imperialism and the resistances to it, the growth and dissolution of empire, the resurgence of the formerly colonised, the emergence of the liminal figure and variously hybrid states of nationhood, and the recognition that the systems by which and in which we come to understand this process are intrinsically related to the processes of imperialism.

In the context of contemporary Britain, British-born Anglo-Pakistani Hanif Kureishi has reflected on the experience of returning to England after a visit to the Pakistani "homeland" of his parent-culture:

Coming back to England was harder than going. I had culture shock in reverse. Images of plenty yelled at me. England seemed to be overflowing with ... things. Things from all over the world. Things and information ... Information though, which couldn't bite through the profound insularity and indifference.

In Pakistan people were keen to know; not only about Asia and the Middle East, but about Europe and the U.S. They sought out information about the whole world. They needed it. ${ }^{17}$

Kureishi thus outlines the disparity between the thirst for knowledge in the Third World, albeit "cosmopolitan", East, and the "grim nostalgia", a post-modern symptom which he sees as characteristic of contemporary materially wealthy Great Britain. It is this disparity reflected in the juxtaposition of these two worlds, that impels Kureishi's writing.

Another central fact of imperialism which is lost in the fray of counter-colonial and post-colonial discourse is that imperialism was a process of both collision and collusion, 
of mutual transformation. While at its centre it sought to preserve the divide between "native" and Westerner, it sought also to transform the native in the image of the Westerner, and in this effort it was not wholly unsuccessful. The counter process, of course, has also taken place, in which the appeal of the post-colonial indigenous has begun to transform the imperial subject.

The post-colonial condemnation of imperialism necessarily comes after the fact. Nevertheless, the ongoing rhetoric of post-colonial discourse indicates how difficult it is, even after empire has officially ceased to exist, to free the mind from its influence. The legacy of imperialism is deeply implicated in contemporary society, and the Booker Prize reflects this pervasiveness. Ambiguities and resistances open up in the reversals that take place between the discourses of the coloniser and the colonised, and these are explored in differing ways in the Booker Prize winning novels. From the resistances of the Collectorate against attack from Sepoys in J.G. Farrell's The Siege of Krishnapur (1973) to the encroachment of modernism on traditional African village life in Okri's The Famished Road, in the lingering effects of colonialism in Penelope Lively's Moon Tiger (1987), in the evaporation of the British "gentleman abroad" in P. H. Newby's Something To Answer For (1969) and in the fragmented identities of Michael Ondaatje's The English Patient (1992)-all of these novels participate in the after-culture of empire or the culture of post-empire.

Many intellectuals feel themselves to be critically engaged in resistance to empire, while they are themselves the product of the institutions, ideas and confluence of peoples and cultures that follow from the assembling and dispersing activities of imperialism. These intellectuals sometimes articulate a kind of double standard. They set themselves the revisionist task of "dealing frontally" with the metropolitan eurocentric culture under the auspices of new and articulate hybrid post-modern nationalisms or complex and interdependent diaspora, but they do so using the methods of imperialism, the "tools" of scholarship and criticism that are the cultural codes of the West. Thus, the discipline is examined in an inherently self-reflexive fashion. ${ }^{18}$ There seems to be little way around this irony apart from to admitting to a kind of self-reflexivity—an acknowledgement that 
there is no view from outside which does not implicate the onlooker-in the attempt to understand the discourse of post-colonalism and post-imperialism.

Furthermore, post-structuralist critique of colonial discourse which reinforces the anticolonialist position (oppressing others is bad, fighting oppression is good) is, as Emily Bauman has claimed, "an order which uses the tools of humanism and representationalism in order to deconstruct them, relying on the belief in free individual reason and the inherent value of human self-determination in order to launch its critique of colonialism." 19 Humanism was, of course, one of the underlying principles of the Enlightenment and modernity and is an ideology which post-modernism seeks to deconstruct. Cultural critique, according to humanism, becomes a linguistic game of critical revelation that is supposedly beyond ideology. On what authority or grounds, however, does this project arise and take shape? Post-colonial critique is fundamentally driven by the goal of a liberation of identity which invests in a particular idea of the human. Humanism is entailed in the critique of the textualised subject. As Said observes, post-colonialism and post-modernism are part of the "invidious universalism" that has connected culture with imperialism for centuries. Perhaps in this sense post-modernism represents a contemporary articulation of the resistance to the lingering humanism that once impelled the expansion of empire during the Enlightenment. The Enlightenment and post-modernism are both themes which are discussed in the Booker Prize winning novels.

This thesis is not concerned with the vagaries, personalities and idiosyncracies of the mechanics of judging: the selection of judges, the differences among panels, the relative merits of unselected books, or the gossip that surrounds the Prize. It is not my purpose to adjudicate on the view that the Booker is merely, as A.S. Byatt puts it, "a lottery" or to defend its absolute literary integrity. ${ }^{20}$ Rather, I am concerned with the way the Prize, over its history, reflects larger patterns of cultural adjustment, inclusion and contestation. The novels which have won the Booker Prize reflect individual histories which acknowledge, complement or resist the culture of imperialism, the post-colonial, and 
post-modern cosmopolitanism that characterises the Western global condition after empire.

\section{Notes}

${ }^{1}$ See Martyn Goff, ed., Prize Writing: An Original Collection of Writings by Past Winners to Celebrate 21 Years of The Booker Prize (London: Hodder \& Stoughton, 1989) and Richard Todd, Consuming Fictions: The Booker Prize and Fiction in Britain Today (London: Bloomsbury, 1996).

${ }^{2}$ Arif Dirlik, The Postcolonial Aura: Third World Criticism in the Age of Global Capitalism", in Contemporary Postcolonial Theory A Reader, ed., Padmini Mongia (London: Arnold, 1996), p. 297.

${ }^{2}$ Edward W. Said, Culture and Imperialism (New York: Alfred A. Knopf, 1993), p. 84. ${ }^{3}$ Salman Rushdie, "The Empire Writes Back with a Vengeance", The Times 3 July 1982, p. 8. Rushdie's title is largely misleading and has been appropriated by Ashcroft, Griffiths, and Tiffin's The Empire Writes Back: Theory and Practice in PostColonial Literatures (1989), in terms which further confuse Rushdie's underlying message. In his book of essays, Imaginary Homelands (1991) Rushdie is concerned with the idea of English being domesticated and extended by the cosmopolitan and "post-colonial" writers from within the frontiers of English language itself. There is no "writing back to the imperial centre", rather the idea is one of the furtherance of the spread of a revitalised and globally dispersed "English" outwards from a cosmopolitan centre of expanding international English. See Imaginary Homelands (New York: Penguin, 1991), p. 49.

${ }^{4}$ Arif Dirlik, "The Postcolonial Aura: Third World Criticism in the Age of Global Capitalism", in Contemporary Postcolonial Theory A Reader, ed. Padmini Mongia (London: Arnold, 1996), p. 300.

${ }^{5}$ Simon Winchester, "The Last Post", Granta 56 (1996), p. 249. 
${ }^{6}$ Arif Dirlik, "The Postcolonial Aura: Third World Criticism in the Age of Global Capitalism", p. 302.

${ }^{7}$ Ella Shohat, "Notes on the 'Post-Colonial'", in Contemporary Postcolonial Theory A Reader, ed. Padmini Mongia (London: Amold, 1996), p. 325

${ }^{8}$ Homi Bhabha, The Location of Culture (London: Routledge, 1994), p. 1.

${ }^{9}$ Bhabha, The Location of Culture, pp. 4-5.

${ }^{10}$ Anne McClintock, "The Angel of Progress: Pitfalls of the term 'Postcolonialism'", in Colonial Discourse/Postcolonial Theory, eds., Francis Barker, Peter Hulme, and Margaret Iversen (Manchester: Manchester University Press, 1994), p. 255.

${ }^{11}$ Bhabha, The Location of Culture, p. 25.

${ }^{12}$ Bill Ashcroft, "Interpolation and Post-colonial Agency", New Literatures Review 28/29 (1994-1995), p. 183.

${ }^{13}$ Shaobo Xie, "Writing on Boundaries: Homi Bhabha's Recent Essays", ARIEL 27:4 (1996), p. 165.

${ }^{14}$ Arif Dirlik, "The Postcolonial Aura: Third World Criticism in the Age of Global Capitalism", in Contemporary Postcolonial Theory A Reader, ed. Padmini Mongia (London: Arnold, 1996), p. 313

${ }^{15}$ Aijaz Ahmad, "The Politics of Literary Postcoloniality", Contemporary Postcolonial Theory, p. 291.

${ }^{16}$ Edward Said, Culture and Imperialism (London: Vintage, 1994), p. xxiv.

${ }^{17}$ Hanif Kureishi, "The Rainbow Sign", London Kills Me: 3 Screenplays and 4 Essays (Penguin: New York, 1992), p. 31.

${ }^{18}$ Said, Culture and Imperialism, p. 59.

${ }^{19}$ Emily Bauman, "Re-dressing colonial discourse: Postcolonial theory and the humanist project", Critical Quarterly 40:3 (1997), p. 83.

${ }^{20}$ A.S. Byatt, "Time To Publish", Independent on Sunday, 14 September 1997, p.8. 


\section{Chapter One}

The Crystal Palace: Novels of the Raj

1. Anglo-India: Nostalgia for the Raj

2. A Minor Victory: J.G. Farrell's The Siege of Krishnapur, 19731

3. India Revisited: Ruth Prawer Jhabvala's Heat and Dust, 1975

4. Anglo-India-Together and Alone: Paul Scott's Staying On, 1978

5. Conclusion: "Orientalism" and inversions of "Self".

\section{Anglo-India: Nostalgia for the Raj}

Joseph Paxton's Crystal Palace (1851) erected first in London's Hyde Park and then reerected in Sydenham Park in 1854 provides a grandiose metaphor for the scope and display of the British Empire. Containing a mass collection and display of objects, curiosities and inventions from the farthest outposts of empire and Europe, the huge iron and glass building acted as a shrine, museum and gallery for the material achievement of empire premissed on the ideas of civilisation and progress. It was an prodigious work of display and classification as well as a monument to exploitation, racism, folly, and greed. The Crystal Palace provoked public controversy. Most of the British cultural establishment condemned it while the public acclaimed it. The "civilised" world regarded it as a symbol of Britain's world vision and leadership, while the ruling classes looked upon it with scepticism.

Each of the novels discussed in this chapter is written from the Anglo-Indian perspective and shares a thematic link with Paxton's Crystal Palace and the Great Exhibition it housed. All three can be understood within the context of Britain's enduring preoccupation with India, its greatest imperial prize, and with the desire of the imperialist to demarcate, "civilize", and display the subaltern subject. All articulate the nostalgia and revision which characterises a phase of post-imperial perception of Anglo-India. 
J.G. Farrell's The Siege of Krishnapur, Ruth Jhabvala's Heat and Dust, and Paul Scott's Staying On are concerned with the display, concealment and decline of empire within a colonial Indian setting. Each is concerned with the display and fragmentation of the "Crystal Palace" of British Empire--the manner in which imperial dissolution and the resultant colonial disenchantment unfolded in various outposts of empire.

Farrell's The Siege of Krishnapur narrates an account of semi-historical fact-the siege by mutinous Indian Sepoys of a Residency in Krishnapur, which housed items "collected" from Paxton's Crystal Palace. Farrell interweaves historical fact with embellished fiction, documenting the tension which precipitates the revolt, the revolt itself, and the siege of the Collector's Residency in which a much reduced Collectorate holds out against the Sepoys until imperial reinforcements eventually arrive. The Siege of Krishnapur is a drama of colonial independence from the perspective of the coloniser, a minor victory for the imperialist presence in forestalling the Indian "mutiny" and is exemplary of racial "classification", the desire to isolate and control according to race. An ironical rhetorical position is assumed by Farrell's characters, in which the Sepoys are judged and admonished with little counterbalancing perspective.

Heat and Dust explores historical amorphousness in the colonial Indian experience in the setting of a minor Indian palace. Viewed from the perspective of its two female protagonists, events of the past find parallels in the present, highlighting differences between colonial and post-independence India but also providing a link in the expatriate exploration of Anglo-India. Jhabvala sustains a narratorial sympathy with the continent which in some ways consumes the imperial histories of her two characters. The "Crystal Palace" of empire is embodied in the Palace of the Nawab of Khartm with whom Olivia, the narrator's grandmother, becomes romantically entwined. The Palace is a last remnant of the courts of princely India and is paralleled by the Collectorate Houses of the Raj, like that for example in The Siege of Krishnapur. Jhabvala enjoins a narrative sympathy with both East and West, Indian royalty and Raj, which is belied by her novel's simplistic title, evocative of the nostalgia of imperial exploration. Her novel engages in the eroticisation of Anglo-India. 
Paul Scott's Staying On, as the title loosely suggests, is a gentle comedy of manners in the expatriate tradition following Indian independence. Centred on two grand colonial hotels and their inhabitants, the story chronicles the decline of the old India of the Raj and the ascendancy of a new commercial ruling class. The novel's two central characters, Lucy and Tusker Smalley, are emblematic of the final "stayers on" of the Raj in India, annexed to a small residency at the back of a hotel. They are "minor" Raj and, their lives having been dedicated to an Anglo-India now eclipsed, they become displaced in their retirement and begin to realise that as their roles have changed their lives have come to lack meaning. Scott's novel is infused with mild pathos at the decline of the Raj, a comedy of gentle hubris and irony which mourns the passing of Tusker and the isolation of his "dethroned" wife. Staying On responds ironically to the appropriation of colonial India and to the nostalgic idealisation of the Raj.

Each of these novels, then, examines the English in an Indian context. Although this context is not always an experience of the Anglo-Indian as portrayed in the India of Heat and Dust, the British in all their various guises-administrative, military, upper and middle-classes-are seen as foreigners and largely uncomfortable in the larger body that is the teeming multitude of the India. The British are also seen as inhabiting the fringes of a sub-continent. No one could doubt the presence of the Raj in India, yet its representatives remain marginalised in strictly numerical terms. The administration and colonial government infrastructure are seen as deluded about their ability to exercise control over the "natives" and are challenged in their understanding of the reality of conditions in India. There is in each of these novels a sense of solipsism and selfdelusion that characterises the British presence in India and the Enlightenment impetus of bringing "civilisation" to the "savage" in the Indian context. This is an arrogance that lasts after the Raj has ceased to exist and India has been granted independence from empire. 


\section{A Minor Victory: J.G. Farrell's The Siege of Krishnapur}

... a scenario unfolded in British policy-making that did not necessarily correspond with what was in reality occurring in the subjugated population. At one level, representation of Indians as morally and intellectually deficient provided the ameliorative motive and justification for colonial intervention. But at another level that same system of representation, depicting the natives as irrational, inscrutable, unstable, and volatile, doomed British rulers to inhabiting an imagined, dreaded world of imminent rebellion and resistance.

Gauri Viswanathan, Masks of Conquest ${ }^{2}$

James Farrell's historically based novel The Siege of Krishnapur, like Paul Scott's Staying On, depicts a crisis in the Raj. Unlike Scott's novel, which chronicles the decline of the Raj from the time of Indian independence, Farrell's novel reinvents a significant moment in the history of the nineteenth-century Raj (the Indian revolt) in a fictitious Indian location, Krishnapur. The Siege of Krishnapur is set in the Dalhousie period of Indian history, which culminated in the Great Revolt of 1857 and the proclamation of Queen Victoria as Empress of India in 1858.

The plot of the novel centres on a community of the British Raj which firstly ignores and then is forced to confront a bloody revolt as the Sepoys of the nearby cantonment rise against the "Crystal Palace" of the Collector's Residence, whose solidity is belied by the militant uprising. The British retreat in shocked defence to the Residency in which the Collector rouses them to a spirited defence among his mementoes of the Great Exhibition and the trappings of Anglo-Indian "civilization". The story thus mirrors the temporary retreat of empire in the face of the revolt of the native "Other". It is the story of an eventually "successful" defence of the Residency, a Raj version of empire's "Crystal Palace", achieved at great cost-human and material. Farrell draws on the historical record in a novel of purposely blurred fiction and fact. This interweaving of invention and history allows him to comment on the traditional chronicling and recording of 
empire. As Judie Newman points out in The Ballistic Bard, Farrell makes ironic comment on the act of cultural subjugation, symbolically blurring the boundaries between military defence and cultural subjugation as he describes the electroplated heads of statues of British poets used as cannonballs in the defence of the Collectorate. ${ }^{3}$

Krishna Rao points out: "[u]nlike Forster or Kipling . . . Farrell never steps out of the British group to encounter directly the Indian way of life." 4 There is very little representation of the Sepoys who lay siege to the Residency in Krishnapur. Farrell restricts himself to the perspective of the imperialist, the Residency and its inhabitants. The Siege of Krishnapur dramatises, satirises and ironises the British presence in India, but its main protagonists, unlike Tusker and Lucy Smalley of Scott's Staying On, learn something from their experiences. While they do not necessarily learn something of India itself, they learn something of themselves in India. Farrell highlights, however, the fact that not all of the Raj had the same intolerant perspective of the colonised Indian "Other". The Siege thus becomes a novel whose sub-theme is the process of historical construction, deconstruction and subsequent reconstruction of the prevailing view of British Indian rhetoric. As Lars Harvett puts it, "A major impact of The Siege is the defamiliarization of the heroic as embodied in the Victorian idea of the civilizing mission of the Empire and its motto: the White Man's burden among the 'lesser breeds' of the world." 5 Farrell's novel remains one-sided but this side is shown with compassionate comedy and ironic ambiguity.

Farrell's narrative procedure has two main distinguishing features in The Siege of Krishnapur. Firstly, Farrell blurs traditionally distinct genres of empire's narration: the novel of action, the historical novel, the novel of metaphysics and ideas, and the novel of fantasy. Thus he seeks to defamiliarise and re-familiarise, in Harvett's terms, notions of the inseparable construction of history and fiction in and of empire. Secondly, and overridingly, Farrell is concerned with the search for an "authentic" Anglo-Indian voice.

The Siege begins with an historical "walk" through the ghost town of present-day Krishnapur with its boarded-up buildings, the "splendid bungalows" of an officialdom long gone, lavish gardens now untended, wild in the rainy season and barren in the dry, 
and whirlwinds of dust over the "Cities of the Silent", which are the former colonial settlement's ancient and dilapidated cemeteries. The events of the novel are thus framed by reminders of their historical contexts; a contemporary re-reading, this is a reconstruction of events long past. (This historical narrative framing device is echoed in the invocation of the cemeteries in Heat and Dust.)

The first warning of trouble in Krishnapur is foreshadowed by the anonymous arrival of a "mysterious distribution" of chapatis which "towards the end of February 1857 . . . swept the countryside like an epidemic. ${ }^{16}$ What seems at first to the Collector to be a practical joke soon becomes an omen of distress and social unrest. Speculation that the chapatis were distributed by order of the colonial government, whose intention it was to see how quickly the administration passed on messages, gives way to misgivings on the part of the Collector and provides the reader with an ironic introduction to the idea of "slippage" between native and imperial cultures - the notion that actually there are many cultures which may be unreadable one to the other.

In The Siege of Krishnapur the imperialists who hold the opinion that British culture is a "superior view of mankind" are forced to reflect on the nature of their superiority in a country and circumstance foreign to its own codes of rhetoric. As Sara Suleri puts it in The Rhetoric of English India:

From the vast body of eighteenth-century historical documentation of British rule in India to the proliferation of Anglo-Indian fiction in the nineteenth and twentieth centuries, the narratives of English India are fraught with the idiom of dubiety, or a mode of cultural tale-telling that is neurotically self-conscious of its own self-censoring apparatus. While such narratives appear to claim a new preeminence of historical facticity over cultural allegory, they nonetheless illustrate that the functioning of language in a colonial universe is preternaturally dependent on the instability of its own facts. ${ }^{7}$ 
With its blurring of fact and ficton, Farrell's "re-writing" of historical material in fictional form allows for the teasing-out of these threads of ambiguity between colonial fact and fiction, themselves worked into a tradition of imperial rhetoric. If the audience for imperial rhetoric was always the empire itself, then self-consciousness was an inevitable quality of its self-description. As Fleury questions a Treasury official: "'Why, if the Indian people are happier under our rule . . . do they not emigrate from those native states like Hyderabad which are so dreadfully misgoverned and come and live in British India?' . . 'The apathy of the native is well known', replied the official stiffly. 'He is not enterprising"'(37).

Fleury's subsequent metaphysical preoccupations are lost on the materialism of the opium agent, Mr Rayne, whose rhetoric masks an industry of imperial exploitation in which progress is measured in profit. The Collector himself, whose concept of progress is enshrined in the "Crystal Palace" of the empire's Great Exhibition, treads a thin line between matters spiritual and practical. He regards the Exhibition as a "collective prayer of all the civilized nations" (53) and quotes from the Exhibition's catalogue as if it were a psalm book: "Humani generis progressus ... The progress of the human race, resulting from the labour of all men, ought to be the final object of the exertion of each individual" (48). The Collector simplistically reminds the company that the ideal of empire is not simply to acquire wealth, but to acquire "through" wealth ". . . a system of administering justice impartially on the one hand, works of art unsurpassed in beauty since antique times on the other. The spreading of the Gospel on the one hand, the spreading of railways on the other" (50). Needless to say, the Collector's impartial justice is that of British law and involves not the slightest notion of a native system of justice, nor does he acknowledge the history of Indian art and culture. The Collector's "collection" reorders the meaning of the individual items themselves in terms of imperial priorities and presumptions. As James Clifford puts it: "The objective world is given, not produced, and thus historical relations of power in the work of acquisition are occulted. The making of meaning in museum classification and display is mystified as adequate 
representation. The time and order of the collection erase the concrete social labour of its making." 8

The interweaving of historical fact and fiction in The Siege of Krishnapur is carried a stage further in Peter Carey's colonial dystopia Oscar and Lucinda, in which a version of the floating church of the Great Exhibition is "paraded" through the Australian outback. Here empire and "Other" collide as binary opposites in a Conradian allegory of mutual misprision. In The Siege, however, we are given the faintest glimmer of Suleri's notion that in the Anglo-Indian condition:

colonial facts are vertiginous: they lack a recognizable cultural plot; they frequently fail to cohere around the master-myth that proclaims static lines of demarcation between imperial power and disempowered culture, between colonizer and colonized. Instead they move with a ghostly mobility to suggest how unsettling an economy of complicity of guilt is in operation between each actor on the colonial stage. ${ }^{9}$

The notion of a "complicity" and "guilt" between the actors on the colonial stage is hinted at in The Siege as Fleury and Lieutenant Dunstaple accompany the Collector on a visit to the Maharajah's palace to meet with his son, Hari. The Maharajah has his own army whom the Collector thinks may be useful if his forebodings about the mutiny of the Sepoys prove correct. The Collector informs Fleury about the "character" of rich natives whose "health was ruined by eating sickly sweetmeats and indulging in other weakening behaviour."

The Collector observes that fortunately, Hari, the Maharajah's son, "had been educated by English tutors and was a different kettle of fish" (69). When Fleury meets Hari he notes a sense of collusion in the relationship here between the native and the coloniser. The ambiguous social status of the privileged Indian is intimated in the manner of their meeting during which Hari "continued to give the impression of striding forward by a simulated movement which, however, only carried him a matter of inches towards 
his visitors ..." (70) The status of the Maharajah's heir, from the British point of view, is that of not quite an "honorary Englishman" yet a wealthy "gentleman" who, while not quite of the empire, is nevertheless not quite the "Other". He is "royalty" but not imperial royalty. Such a status obliges the Maharajah's heir to stand his ground and be approached:

The mimed movement in the presence of inferiors entitled to some respect, which included all the British in India, had developed swiftly in the course of social contact with Europeans so that by now it had become not only quite unconscious, but also so perfect as utterly to destroy perspective. The result was that Fleury found himself having to advance a good deal further than he expected and arrived at his host somewhat off balance, his last few steps a succession of afterthoughts.

The ability of the Maharajah's mimed action to "destroy perspective" and to throw Fleury "somewhat off balance" highlights the ambiguous element of social collusion between colonised and coloniser, and literalises the ambiguous occupation of space between the two. Hari's social position is determined with a subtlety which confuses and dismantles the binary distinction between the Indians and the British in India, between the colonised and the coloniser, and which disrupts the flow of familiar imperial social relations.

Hari escorts Fleury and Harry Dunstaple on a tour through his palace's "many wonderful things" in parallel with the Collector's exhibition pieces in the British Residency. The fact that Hari himself intones the rhetoric of empire is less significant (although ironic) than Farrell's portrayal of his social responses and ambiguous status. It is as if the binary relationship which empowers both self and "Other" breaks down in the dramaturgical actions of Hari in the presence of the British. Fleury's "loss of balance" and misreading of Hari, and Hari's concern with the materialism of imperial "progress" 
represent a kind of powerlessness and somnambulance at the centre of this ambiguous collusion. As Suleri puts it: "The necessary intimacies that obtain between ruler and ruled create a counter-culture not always explicable in terms of the allegory of otherness: the narrative of English India questions the validity of both categories to its secret economy, which is the dynamic of powerlessness at the heart of the imperial configuration."10

In this case it is not clear who is ruler and ruled. Hari is the son and heir of an Indian prince, and therefore royalty, but his royalty is in many ways at the behest of British India. The dynamic of collusion between the two groups thus defies a stable relationship between ruler and ruled. Fleury's loss of balance and perspective when meeting Hari together with Hari's mimed action of entreaty represents a dramaturgical example of the kind of powerlessness that Suleri identifies, as the two actors play their parts in the "imperial configuration" so as almost to cancel each other out.

The plot of The Siege of Krishnapur ostensibly centres on the defence of the Residency from Sepoy attack, but a major sub-theme focuses on the intricacies of the colonial-imperial relationship and involves a subtle analysis of those who exemplify the power relations within it. A parody of the social mores of English-India and the Crystal Palace of the Great Exhibition is carried out in the novel. The defence of the Residency from the Sepoy revolt has a sub-thematic parallel in Fleury's symbolic attack on the nature of imperial progress. Significantly, he wears a jacket fashioned from billiard cloth green during the defence, an obscure reference to his sympathies with the fable of Robin Hood, who stole from the rich to give to the poor.

Fleury's idealism continues despite the onset of the siege. He continually resists the prevailing idea that British culture is a "superior culture", explaining to Louise that a "civilization of the heart" is needed in India, rather than "sordid materialism": "'Only then will we have a chance of living together in harmony. Will there even be classes and races on that golden day in the future?'" (118) Fleury refuses to let his idealism be assimilated by the prevailing norm which bolsters the common image of the superiority of empire behind a rhetoric of impartiality, truth, and objectivity. The advent of the siege makes the Collector reflect on British rule, although rather than interpret it as evidence against the 
superiority of British rule he asks "the perplexing question of why, after a hundred years of beneficial rule in Bengal, the natives should have taken it into their heads to return to the anarchy of their ancestors" (159). It is as if the colonial process is completely onesided, and the Collector's mental landscape is devoid at this stage of any real empathy with the Indian population. He cannot see past his enshrined ideals of progress through civilisation, and the spread of civilisation through colonisation:

One or two mistakes, however serious, made by the military in their handling of religious matters, were surely no reason for rejecting a superior culture as a whole. It was as if, after the improving rule of the Romans, the Britons had decided to paint themselves with woad again. 'After all, we're not ogres, even though we don't marry among the natives or adopt their customs.' . . 'Things are not yet perfect, of course ... All the same, I should go as far to say that in the long run a superior civilization such as ours is irresistible. By combining our advances in science and in morality we have obviously found the best ways of doing things. Truth cannot be resisted! Er, that's to say, not successfully', the Collector added as a round of shot struck the corner of the roof and toppled one of the pillars of the verandah (159).

The Collector, however, does gain some awareness of the grandeur of his mistakes and the blindness of his rhetoric. Overcome by a feeling of helplessness, he decides to free Hari and the Prime Minister. He realises that his experiences in India have largely been reflections of his own culture; that he has not experienced the indigenous Indian culture in any real sense-that, as Suleri points out, the concept of colonialism "precludes the concept of exchange by granting to the idea of power a greater literalism than it deserves. "11 Although he may have "ruled" and occupied the administrative executive, in actuality the Collector comes to a vague awareness that he knew very little of the nature of the country in which he held and attempted to exercise such power: 
He realized that there was a whole way of life of the people in India which he realized he would never get to know and which was totally indifferent to him and his concerns. 'The Company could pack up here tomorrow and [this fellow] would never notice... And not only him . .. The British could leave and half of India wouldn't notice us leaving just as they didn't notice us arriving. All our reforms of administration might be reforms on the moon for all it has to do with them.' The Collector was humbled and depressed by this thought (210).

Farrell's novel concludes in irony. As he crosses for the last time the dusty plain between Krishnapur and the railway while leaving the Residency, the Collector gains a kind of self-knowledge and acknowledges the emptiness behind the authority associated with his imperial role. He experiences finally the vastness of India: "he realised then, because of the widening perspective, what a small affair the siege of Krishnapur had been, how unimportant, how devoid of significance"(311).

The siege is insignificant against the vastness of India and the proliferation of its peoples, castes, histories; yet Farrell depicts the human element in the siege- - the gradual awakening of individuals to the truth behind the rhetoric of English India. The Collector and the "Crystal Palace" of the British community of the Residency are brought up against the limits of their own history and situation. Farrell concludes the novel with the afterthought that it was surprising how quickly the survivors returned to a "civilized" life in "peaceful" England, with few memories of the dark ordeal during the siege. Of the Collector he offers one last speculation: "Perhaps by the very end of his life, in 1880, he had come to believe that a people, a nation, does not create itself according to its own best ideas, but is shaped by other forces, of which it has little knowledge" (313).

The Siege of Krishnapur is concerned with colonial-imperial mis-readings and rereadings, with the construction and deconstruction of the curious blend of history and fiction which forms the rhetoric of the colonial Raj. The mis-readings are largely those of 
the British community in India, interpreting a territory that defies the fixity and positivism of their view. The re-readings Farrell makes in The Siege revise a "history" of empire premissed on the "Crystal Palace" of progress and civilisation. As Suleri puts it, "If the limits of cultural knowledge dictate the curious genealogy of English India, then its chronology is intimately linked with a failure of ignorance to comprehend itself, or to articulate why the boundary of culture must generate such intransigent fears. "12

\section{India Revisited: Ruth Prawer Jhabvala's Heat and Dust}

Colonial India and a re-reading of a contemporary India figure in Ruth Prawer Jhabvala's 1975 Booker prize-winning novel, Heat and Dust. Heat and Dust tells two parallel stories: that of a young English woman who is seeking her family history in India, and that of her grandfather's first wife, Olivia. The story of the narrator's grandfather's first wife takes place in 1923, while the narrative present is that of the early 1970s.

The two parallel stories intersect once in the novel when the two female protagonists of the novel conceive children at Baba Firdaus's shrine: Olivia possibly by the Nawab of Khatm, and the contemporary narrator of her story by Inder Lal, her clerk boyfriend. Jhabvala thus explores two Indias: the first from two perspectives, the colonial India of Olivia, her husband Douglas, and the alterior colonised India of the Nawab; and the postcolonial India of the contemporary unnamed woman: "India always changes people, and I have been no exception. But this is not my story, it is Olivia's as far as I can follow it." 13

In Heat and Dust Jhabvala is concerned largely with British India from the perspective of two not dissimilar women who live parallel lives in the story, the first between February and September 1923, and the second between the same months fifty years later. The younger woman traces her family history in India and chronicles the events of the scandal involving her grandfather's first wife, Olivia, and by retracing her steps demonstrates how emancipation has altered the social mores of the past and present. The change in social climate between colonial and post-colonial eras is largely portrayed by 
difference to each woman's response to her conception of a child. After aborting her child, unsure of whether the father is husband Douglas or the Nawab, Olivia retreats to the mountains and lives a life of silent retreat. The contemporary woman decides to keep her child after an unsuccessful attempt at an abortion, and she too retreats to the Himalayas. The reader is left, however, with the impression that the second retreat is less a turning away than it is a search for self-knowledge.

The cultural sensibility of Heat and Dust is ambiguous. The novel directly concerns itself, unlike Staying On and The Siege of Krishnapur, with collusion between the coloniser and the colonised, between the British and the Indians (in the form of the love affairs of the two female protagonists). Thus the novel concerns itself, at least ostensibly, with the intimacies and intricacies of cultural interaction, marking a distinction from a two-dimensional representation of colonial fiction characterised by a binary relationship between empire and 'Other' on the one hand, and the static demarcation of cultural boundaries on the other. The success of the novel is hinged on its ability to communicate ambiguity and ambivalence, a mutual desire for and a mutual fear of the 'Other', so that the idea of the self becomes liminal and complex. However, where The Siege concentrates on the construction and deconstruction of empire's self-reflexive representation, Heat and Dust offers a somewhat shallower perspective on the rhetoric of colonial India. As Richard Cronin puts it:

Jhabvala explores how independent India is connected with, and severed from, its imperial past. But modern India she knows, whereas the Nawab of Khatm, an Indian prince ruling his tiny estate surrounded and dominated by British India, is a figure from a past she has only read about. Heat and Dust is concerned not only with the relationship between two Indias, but with Jhabvala's relationship with her literary predecessors, the Englishmen who described life in Indian princely states in the 1920s. ${ }^{14}$ 
Jhabvala's own experience married to an Indian architect, having lived in India for twenty years, and now living in New York is that of an exile from India. Her access to and experience of post-independence India is thus significant. Like Forster before her, however, Jhabvala avoids the issues Suleri raises of national and literary ambivalence in the Anglo-Indian context, namely while allowing her novel to provide their context:

\begin{abstract}
How can the dynamic of imperial intimacy produce an idea of nation that belongs neither to the coloniser nor to the colonized? Is nation itself an alterity to which both subjugating and subjugated cultures must in coordination defer? In what ways does the idiom of otherness simply rehearse the colonial fallacy through which India could be interpreted only as the unreadability of romance? ${ }^{15}$
\end{abstract}

In Heat and Dust, the "Crystal Palace" of empire is shadowed by the Nawab of Khatm's palace which offers an alternative to the grandeur of empire: "Protected by high pearl-grey walls, the Palace is set in spacious grounds with many tall trees. There are fountains and water channels, garden pavilions, and a little private mosque with a golden dome" (11). In the narrative present, the palace is vacant, "just a marble shell" with the Nawab's nephew, living in London, having inherited the palace and now attempting to sell it to the Indian government: ". . . all that is left, here and there like shipwrecks floating in marble halls, are some broken Victorian sofas and the old cloth fans pullpunkahs hanging dustily from the ceiling" (12). However, in Olivia's day the palace of the Nawab was grand. She first meets the Nawab when invited to dine there with her husband, Douglas, the Crawfords (the Collector and his wife), and other officials of Satipur. Olivia feels she has come to the right place and a situation far more exciting than being "alone in her big house with all the doors and windows shut to keep out the heat and dust" (14). Conversely, as Haydn Williams points out, it is as if: "[t]he Nawab's ambivalently evil charm can ... only work in the "heat and dust", in the crumbling 
remnants of two empires, one ostensibly Muslim and the other ostensibly Christian, both doomed to die in the plains of a timeless India." 16

In the narrative present, the narrator meets with a couple of young English travellers. She finds them odd and asks the woman why they came to India: "[t]o find peace" she replies, "But all I found was dysentery" (21). Thus the glamour of the colonial Raj is contrasted with the discomfort of the contemporary couple's experience of India. While Olivia participates in her surroundings and has some emotional investment in them, the voice of the narrator throughout the novel remains detached. The somewhat underdeveloped representation of alterity that is a feature of The Siege of Krishnapur is continued in Heat and Dust. While this neglect is in many ways a conscious and satirical voice in The Siege, the satire and irony is less evident in Heat and Dust. In a reversal of Mr Hopkins's description of the Maharajah in Krishnapur as "weak" (and Farrell's ironic portrayal of this), the Nawab in Heat and Dust castigates his English secretary, Harry: "[he] is a very weak person. Because he is so flabby in his body I think. He is not a proper Englishman at all. No-shall I tell you-I think he is a very improper Englishman" (43). The Nawab's notion of a proper Englishman is that of Mr Hopkins, the embodiment of the Raj-upright, fit, calm, civilised and, of course, male. However, in ridiculing his employee in front of Olivia he is turning British imperial values against themselves. Ironically, the Nawab at the novel's conclusion is described as having become... so fat there was something womanly about him" (175).

The Nawab's interest in Olivia is obvious to both of them from the outset. As the weeks pass he entices her on a picnic to the shrine of Baba Khan, which is an oasis of tranquillity, of green and running water amid the "heat and dust". Their moment of intimacy is an inverted parody of Forster's famous pronouncement on the possibility of friendship between the English Fielding and the Indian Aziz of A Passage To India:

"Why can't we be friends now?" said the other, holding him affectionately. "It's what I want. It's what you want." 
But the horses didn't want it-they swerved apart; the earth didn't want it, sending up rocks through which riders must pass single file; the temples, the tank, the jail, the palace, the birds, the carrion, the Guest House, that came into view as they issued from the gap and saw Mau beneath: they didn't want it, they said in their hundred voices: "No, not yet," and the sky said: "No, not there."17

By comparison at the green grove and cold water of the shrine amid the desert, the Nawab asks: "'Do you believe that it could be so? That there is a miracle?' . . . They were side by side. He looked at her intensely and she looked down at her hands which she was dabbling in the water. It was fresh and fast running but so shallow that it just trickled over her fingers. She said, 'Perhaps a very small miracle'" (46).

Heat and Dust parodies not only Forster's A Passage To India but also the entire genre of colonial Anglo-Indian fiction, and it does so without the deliberate irony of Farrell or Scott. As David Rubin has put it, "[Jhabvala's] Indian fiction has constituted a clever and disarming set of variations on the long traditions of the Anglo-Indian novelists". ${ }^{18}$ When Harry confronts Olivia with her infidelity and points out that the Nawab has not taken her to meet his mother, the Begum, and her ladies, that in effect he has used her in his contempt for the Raj, she responds with a naivete devoid of irony: "Don't look like that, Harry. You're being like everyone else now: making me feel I don't understand. That I don't know India. It's true that I don't, but what's that got to do with it? People can still be friends can't they, even if it is India" (103).

Like Forster, Jhabvala signifies the ultimate unreadability of India in the metaphor of landscape and the sky. Like Forster, she implies that India cannot be read by AngloIndian eyes, that there is a quality of place that remains impenetrable and aloof to the nonIndian, a cultural "slippage" between registers of attention. As Ralph Crane puts it, "[i]t is important to realize that the negative images have become more numerous with the increasing incidence of European characters in her novels; it is not India she is thus characterizing, but its effect on the European characters in her fiction." 19 
The effect of India on the European character is reinforced in the narrative present as Dr Gopal explains to the narrator:

'this climate does not suit you people too well. And let alone you people, it does not suit even us.' . . Let us admit for the sake of our argument that we Indians are fit to live here-where else are we fit for? ... 'But no one else,' he said. 'None of you. You know in the bad old days you had your Clubs and they were reserved for British only? Well now it is like this that we have our germs and we have reserved these for ourselves only. For Indians only! Keep out!' (158-159)

Dr Gopal reinforces the binary relationship between coloniser and "Other", which Olivia's relationship with the Nawab goes some way towards undermining, and Jhabvala's portrayal of this relationship strikes the reader more directly than Farrell's gradual questioning of the colonial native situation. The black humour of Gopal is echoed by Haydn Williams, who observes that: "[i]n both A New Dominion and Heat and Dust, the cemetery is the most potent symbol of British involvement with India."20 Dr Gopal's views are paralleled by Major Minnie's from the British perspective. In the authentic voice of the Raj, he proclaims: "[i]t is all very well to love and admire India . . . but always with a virile, measured, European feeling. India, for Major Minnie always remained an opponent, if necessary fought against from without and, especially, from within: from within one's own being" (171). Inadvertently, however, Major Minnie holds the key to a genuine British experience of India, one in which the "heat and dust" out there is also the heat and dust within. The fear of the foreign "Other" is the fear of the exotic and the "Other" within. The unreadability of India corresponds to the unreadability of the self in India. Every acknowledgement of a world other than empire is an acknowledgement of the constraints of empire itself, without which the "Other" (and the self) would make no sense. As Sara Suleri puts it, "[t]o tell the history of another is to be pressed against the limits of one's own, thus culture learns that terror has a local 
habitation and a name ... the story of culture eschews the formal category of allegory to become a painstaking study of how the idioms of ignorance and terror construct a mutual narrative of complicities." 21 The mutual narrative of complicities is contained in Major Minnie's desire to separate the alterity of India from the self, to refuse to participate in the narrative of underlying complicity that would signify immunity to the "heat and dust".

\section{Anglo-India-Together and Alone: Paul Scott's Staying On}

Many people in England probably feel a certain remorse or regret about the nation's Indian experience, but there are also many people who miss the good old days, even though the value of those days, the reason they ended, and their own attitudes toward native nationalism are all unresolved, still volatile issues.

Edward Said, Culture and Imperialism 22

Staying On, the fifth and final novel in Paul Scott's chronicle of Indo-English relations between 1942 and 1947, the "Raj Quartet", provides an epilogue to The Jewel in the Crown (1966), The Day of the Scorpion (1968), The Towers of Silence (1971) and A Division of the Spoils (1975). Staying On won the Booker Prize in 1977. Set in India in the 1970s, two decades before Said's observation above, Scott's novel revisits the setting of his last three novels, the hill station of Pankot, and depicts the lives of two characters who featured only briefly in the "Quartet", "Tusker" Smalley and his wife, Lucy, who on the colonel's retirement from the army have elected to "stay on" in Pankot.

Staying On begins with Tusker's death by heart attack while "staying on" in an annexe of an old Indian Pankot hill station hotel, "Smith's". Scott's novel recounts the days before Tusker's death and chronicles the conditions and lifestyle of the Colonel and Lucy, who decide to remain in an increasingly un-Anglo-India after most of the British have left. Scott's novel is an often humorous account of the whisky-and-gin-soaked 
"club" of imperial decline: "but then Tusker was a member—-the last surviving member in Pankot, with his wife—of the old school of British and needed his liquor."23

The novel depicts the pomposity and faded grandeur of Anglo-India in parallel with the fates of Pankot's two hotels: the Shiraz, a new five-storey glass and concrete structure, where Lucy has blue rinses, and the older Smith's hotel, in an annexe of which the couple live. The events leading up to Tusker's death are coincidental with the serving of final notice on the premises which they rent from Indian owners, Mr Bhoolabhoy (manager) and Mrs Bhoolabhoy (proprietor) to make way for a new business venture: "This had been the pattern since the days of the raj. After the raj went there had been bad times, good times, near-disastrous times, times of retrenchment, times of ebullient hope, as Pankot waxed, waned, waxed again in popularity. But for Smith's now it all seemed to be coming to an end" (11-12).

Like Heat and Dust and The Siege of Krishnapur, Staying On is as much a depiction of British character in the distorted mirror of Anglo-India, as it is of the intricacies of Anglo-Indian cultural exchange, or rather, it is a depiction of that exchange, through the ironic detachment and humour of anglophile eyes: "Tusker was a man who needed irritants. He often invented them. Here was one ready-made" (22). In Staying On it is the Indians who are the anthropologists and the British who are the apologists, not that there is a great deal of apologising done. Staying On depicts the recognition, attempted adjustment to, and disregard of imperial decline, and simultaneously focuses on the ingenuous detachment of the Indians from their former rulers. This detachment takes many forms, from over-politeness or stoic service, to obliviousness. As Lucy says to Ibrahim:

'I find these little plots and plans foreign to my nature, to my preference for the way of dealing with things. There was a time when we, when we, did not have to go in for such things, a time when . . . an Englishman's word is as good as his bond because he is known 
throughout the world to be an honest man.' 'Honest because British, Memsahib.' 'Yes, Ibrahim. But that is all so long ago' (55-56).

The pomposity of the British character is subverted by Scott, as the Indian servant Ibrahim unquestioningly mimics the tone of his Anglo-Indian employer.

The era of the large residencies of the imperial Raj is largely finished in Staying On. The commerce of Pankot is a model of Anglo-Western materialism. The large hotels are Indian-owned, and the Indians now think of Britain as a second home, even if the Britain of Lucy and Tusker Smalley represents a nostalgia for the "splendour" of an exported colonial Britain. Many Indians themselves are England-Returned. As Ibrahim says to Joseph, hired to tend the Smalleys' garden:

'I was telling you about my brother-in-law, making many tips, saving, saving.'

'To buy own restaurant?'

'No, to buy shop, also to send money to my sister. In shop he is working very hard and making good profits, so then buying house big enough for sub-letting. You understand sub-letting?' Joseph shook his head. 'Big house, many rooms, accommodation for many people. All Indians. All living in Finsbury Park' (63).

The end of the imperial hotel of the Raj is largely depicted by Indian assimilation of the Anglo-Western presence. Throughout Scott's novel social hierarchy and Western materialism are portrayed in a mixture of absurdity, humour and pathos, as the former belief in Anglo dominance is engulfed and subverted by Indian culture. Nostalgia for the Raj forms the basis of Scott's novel, and this nostalgia is shown to belong not exclusively to the former Raj. Thus, Ibrahim, the Smalleys' servant, after having been sacked for the fourth time in a year, is portrayed as having affection for Tusker Sahib and Memsahib and the security of their social mores: "He had worked for the Smalleys for 
several interesting tumultuous years and wasn't ready yet to lose them. They were the last survivors of Pankot's permanent retired British residents. This and the fact that he himself was England-Returned gave him a certain cachet among the servants" (22).

However, nostalgia for empire fits uneasily with the complexity of the Indian continent, and its ancient and complicated religious and caste systems, which are only hinted at in the novel. Scott subverts the stereotype of Anglo-Indian mysticism, exemplary in such colonial novels as Kipling's Kim (1900-1901) and Forster's A Passage to India (1924), with an ironic and witty comedy of cultural exchange. Humour is Scott's overriding narrative device, juxtaposing the ironies of Western materialism with the enigmatic spirituality and whimsical pragmatism which he portrays (at least through the eyes of the Anglo-Indian) as peculiarly Indian qualities:

... Ibrahim trusted no Indian doctor to treat a white man. At a pinch a Muslim doctor would do, but a Hindu doctor never. The nearest European doctor though was down in Nansera, and he was an Austrian and a Catholic and the Catholics were worse than the Hindus because they believed in human suffering and uncontrolled birth-rates. The Hindus at least had offered a free transistor to every Indian having a vasectomy. But carrying a transistor had at once become unfashionable among the younger men. That lawyer's babu, Pandey, whose transistor was enormous, must have lost his marbles (31).

Thus even if the prestige of an English-India is waning in Staying On (at least in terms of the former Raj), the attraction of an Indian Britain is in the ascendant. The social hierarchy and values of the Raj have largely been replaced by a laissez-faire capitalism. While the representations of Western culture are controlled by the English in India, these controls no longer apply in England itself. There is a sense in Staying On of the inevitability of the end of empire as the world outside the Pankot Raj no longer resembles the picture of empire that the Anglo-Indians preserve for themselves. The Smalleys live 
in a state of nostalgia for a construction of empire that never existed. Thus while their servants never see the end of movies in India because they are occupied in getting the car ready for their employers, "back" in Britain they are able to "catch up": "[i]n a London cinema he had watched Vivien Leigh running through the mist at the end of Gone With the Wind" (72). For Ibrahim and Hussein, a Western form of nostalgia is invoked by endings in glamorous movies. Theirs is a nostalgia for the nostalgia of endings. It is even more ironic that these endings are finally seen in Britain rather than the Anglo-India of Pankot. Appropriation is thus shown on the part of the Indian rather than the British. It is as if cultural assimilation on the part of the "colonised" is portrayed as the undoing of the imperial presence through its refusal to create any culture that does not resemble a nostalgia for a vanished colonial culture.

Thus Scott's novel proceeds in a humorous and ironic way to the conclusion that the Raj evolved into a model of empire which had no basis outside nostalgia. Tusker is shown as on display in Staying On, he himself has become the "exotic". Even his wife, Lucy, recognises him now only for his preposterousness and exhibitionism:

She could believe nothing Tusker said or did because nothing he said or did revealed continuity of thought, intention or action. $\mathrm{He}$ had become devious in spite of that combative forthright manner. This meant that she could no longer believe in Tusker. She had begun not to do so on the day the British left India and they had stayed on, on loan. His personality change had really dated from then. . . . (98)

In Lucy's view Tusker's character changes following India's independence. If Tusker is to be read as colonialism incarnate before this day, then by implication he is "postcolonial" in temporal terms thereafter. Lucy's sense of Tusker's "deviance" corresponds with the collusion and ambivalence that characterises cultural exchange in the postcolonial era. The fact that Tusker has obviously not adapted to post-colonial India and remains firmly "colonial" makes Lucy's "reading" of Tusker all the more ironic. In fact, 
it is not Tusker who has changed but her society as the security of the Raj has slowly crumbled, or become overgrown with Indian assimilation and appropriation since independence. However, as Yasmine Gooneratne puts it, "Tusker's love affair with India lasts throughout his life, and is deeply felt though expressed, characteristically and comically, in negatives-he does not, he informs Lucy with asperity, wish to grow old in bloody Stevenage." 24

In ironic mimicry of Kipling's oft-quoted line from "The English Flag": "And what should they know of England who only England know?"25 Lila Bhoolabhoy informs Frank Bhoolabhoy: "[w] hat happiness you will give me world-wide. What is Pankot but a beginning? What do we know of Pankot if we only know Pankot?" (139)

Lucy's sensitivity is slighted by the impasse between herself and Tusker and a sense of their shared knowledge of the crumbling of the "old ways" of British-India in which they played less than fulfilling roles. Tusker's gruff stereotypical pomposity is matched by Lucy's wistfulness; her sense of the vacuity of the social hierarchy is coupled with her profound sentimentality for a place in empire which was at best peripheral. Her life, like Tusker's, has been one of observation more than participation, but without the sense of detachment that characterises the consciously observant. She recounts the ceremony in Pankot on independence eve, on the parade ground of the Pankot Rifles:

At sundown, they beat the retreat ... There was still one small British contingent on station, a mixed bunch. They marched on last after the Indian troops marched on . . . They played all the traditional martial British music . . . One by one all the floodlights were put out leaving jut the flagpole lit with the Union Jack flying from it. Colonel Layton and the new Indian colonel stood at attention side by side . . . And Tusker put his hand in mine and kept it there. . . all through God save the King, and all through that terrible, lovely moment when the Jack was hauled down inch by inch in utter, utter silence (170-171). 
The 'terrible, lovely" moment when the Union Jack was hauled down and replaced by the Indian flag is the symbolic climax of Scott's Staying On. Lucy holds Tusker's hand as independence is announced. Thereafter, the portrayal of British decline is sustained by the portrayal of those remaining in an increasingly Indian India in which the presence of the vestiges of Raj is tolerated in inverted mimicry for its "quaintness" and imperial "exoticism". Tusker and Lucy represent a generation displaced. They are displaced from a crumbling empire and the semi-permanence of a faded Raj, displaced from a unifying social reason for remaining in India. Childless, they have no ties to the "new generations of English and Indians who met and made friends with one another" (173). The relationship with the Indians of their own generation has also altered with independence. It is not so much that they are now forced to look at the Indians as "people", but that they are forced to examine themselves in the reflection of a changed Indian "Other": "however friendly you were with Indians of your own generation, the generation that had experienced all the passions and prejudices, there was somehow in that relationship a distant and diminishing but not yet dead sound of the tocsin" (173).

Scott's mixed metaphor of the "dead sound of the tocsin" is a telling one for the continuing misreading of India by the generation of Tusker and Lucy, or rather their reluctance to engage with India in any terms other than those of the now fading Raj. As Janis Tedesco points out, the Smalleys are the members of an authentic Raj which still exists in people's memories: " . . the old British Raj had not been eliminated but merely replaced, by a new Hindu Raj." 26 The mainly Indian servants who remember the British Raj see the Hindu ironically as unauthentic though they may be dominant socially and financially. Thus, for example, to Ibrahim Lucy was a true Memsahib and Mrs Bhoolabhoy a comic copy. This ascendance of the Hindu Raj is recognised by Lucy also when during Holi, a spring festival of the Hindus, she reflects on Tusker's embrace by Coocoo Menektara, a well-off Hindu at their party: "When Coocoo embraced Tusker it was obvious to Lucy that Coocoo was thinking "Yes, you're nice, you can be fun, you make us laugh, you're always welcome, but you're an Englishman so you represent the defeated enemy"(173). 
Staying On is primarily a humorous depiction of nostalgia for the Raj in British India, and takes a sympathetic look at a couple's displacement in a changed and changing postcolonial India. In many ways Scott's novel is a parody of the genre of Anglo-Indian novels of Forster and Kipling; the postscript to Scott's own "Raj Quartet", it is all the more significant for dealing with the British "victims" of the Raj. The stayers-on are those British who remained in an India which never truly belonged to them. Once again India is shown as being impenetrable by the British; it is too vast, too obscure, too shifting.

With Tusker now gone Lucy is left alone in India, her sense of displacement ever more acute. With the fragments of empire's "Crystal Palace" around her and a younger post-colonial populace that no longer recognises the same things in those fragments, Lucy grieves for her now dead husband and for the life shared with Tusker among the fading remnants of the Raj. As David Rubin puts it: "Lucy, alone, manages to voice the melancholy longing of a generation of unimportant British colonials, committed hopelessly to India. . . ."27 Lucy's displaced and fragmented world provides a downbeat corollary to the teeming multiplicity that is invoked in Rushdie's Midnight's Children. As the presence of the British Empire in India waned, offering its expatriates little more than memory, nostalgia and remorse, the birth of the independent nation was announced with an Indian fervour recognised in the act of colonisation and neither assimilated nor tamed.

\section{Conclusion: "Orientalism" and inversions of "Self"}

These novels of fondness for British rule in India, written in the 1970s, anticipate what Salman Rushdie has described as a kind of Raj revisionism and nostalgia which he sees as the middle-brow literary response to the rise of conservative ideologies in 1980s Britain. Rushdie's claim is that British culture underwent a form of "cultural psychosis" in which it postured like the great power it no longer was. ${ }^{28}$ The ironic retelling of events in the narrative of empire in such novels as Staying On and The Siege of Krishnapur often takes the form of parody, pastiche, and allegory as imperial pomposity 
is laid bare and the unruly basis of civilisation exposed, where justice frequently correlates to the loudest voice, and truth and fictions are interchangeable. Each of these novels metaphorically reflects a literary fragment of the "Crystal Palace" of empire without acknowledging, as copiously as Rushdie, the untold Indian stories of empire, the historical silences, the gaps left by imperial rhetoric. The novels themselves function as a display of Anglo-India and the changing nature of Anglo-Indian relations in the twentieth century.

The Anglo-Indian novels considered in this chapter are concerned with the rhetoric of colonialism and adopt critical or at least satirical and historical perspectives towards it. Their narratives of ambivalance or counter-discourse are subsumed within the enduring eroticisation and desire on the part of the British for the sub-continent and the Oriental subject - the "objective" view that envisioned, "the unrestrained inscription of alterity that could be neutralized and transcended at the same time, enabling a confirmation of Victorian selfhood as simultaneously incorruptible and all-embracing, stolidly unchanging as well as dynamic and progressive, protectors of the other as well as protected by the other." 29 This involved different degrees of alienation and enhancement of the self-image.

To the uninitiated English, the Indian sub-continent held up a mirror wherein they could see a reflection of their own altered, orientalised lives. A nostalgia for the Raj illustrates a contemporary Britishness that looks both favourably and affectionately on the culture of empire and the intermingling of cultures in its aftermath, at the same time as it re-examines the sites of colonial grievances and the faltering of the Enlightenment ideas of progress and emancipation.

The Raj was concerned with the defence of Victorian identity as much as it was with the acquisition and display of alterity. The Victorians believed that (in the manner of the Victorian phrenologists) they could read inner from outer selves. Differences of external form were thought to derive from pre-existing internal character. However, the British efforts to apply this inductive method to the East were ultimately confounded because the 
Orientals appeared to divide their inner and outer selves with ease. It was this observation that gave rise to British view of the deceptive, "inscrutable" Easterner. ${ }^{30}$

By comparison, when the Oriental became Westernised it was the British who knew the internal character and the Orientals who were fooled. It is the enduring resistance to this adoption of the Western persona coupled with the collapse of confidence in Victorian values as empire faltered that marks the liminality of British preoccupation with the East. This liminality and ambivalence remains in the "in-between" spaces of Homi Bhabha's articulation of the cross-cultural milieu and Salman Rushdie's and Michael Ondaatje's notion of the "translated person" bome across cultures. In The Siege of Krishnapur, Heat and Dust, and Staying On, the complexity of the East-West gaze is self-reflexively contained within and belied by these novels' depictions of landscape, ceremony, and cultural exchange and interaction. The exotic products of empire, gathered under the Enlightenment impetus for progress and discovery that culminated in the Great Exhibition of 1856 are once again displayed to the eager nostalgic gaze of the middle-class, the sceptical one of post-colonial intellectuals, and also to the dissenting voices of those on display.

\section{Notes}

${ }^{1}$ Dates indicate the year in which the novel was published and in most cases correspond to the year the novel won the Booker prize.

${ }^{2}$ Gauri Viswanathan, Masks of Conquest: Literary Study and British Rule in India (London: Faber and Faber, 1989), p. 11.

${ }^{3}$ Judie Newman, The Ballistic Bard. Postcolonial Fictions (London: Arnold, 1995), p. 1.

${ }^{4}$ A.V. Krishna Rao, "History and the Art of Fiction: J. G. Farrell's Example: The Siege of Krishnapur ", The Literary Criterion 23:3 (1988), p. 45.

${ }^{5}$ Lars Hartveit, "The Imprint of Recorded Events in the Narrative Form of J. G. Farrell's The Siege of Krishnapur", English Studies 74: 5 (1993), p. 468. 
${ }^{6}$ J.G. Farrell, The Siege of Krishnapur (London: Flamingo, 1985), p. 10. All further quotations from this work are taken from this edition and are followed by the relevant page number in parenthesis.

${ }^{7}$ Sara Suleri, The Rhetoric of English India (Chicago: University of Chicago Press, 1992), p. 3.

${ }^{8}$ Clifford, The Predicament of Culture, p. 220.

${ }^{9}$ Suleri, The Rhetoric of English India, p. 3.

${ }^{10}$ Suleri, The Rhetoric of English India, p. 3.

${ }^{11}$ Suleri, The Rhetoric of English India, p. 2.

${ }^{12}$ Suleri, The Rhetoric of English India, p. 2.

${ }^{13}$ Ruth Prawer Jhabvala, Heat and Dust (London: Penguin, 1994), p. 2. All further quotations from this work are taken from this edition and are followed by the relevant page number in parenthesis.

${ }^{14}$ Richard Cronin, "The Hill of Devi and Heat and Dust", Essays in Criticism 36:2 (1986), p. 142.

${ }^{15}$ Suleri, The Rhetoric of English India, p. 10.

16Haydn M. Williams, "Mad Seekers, Doomed Lovers, and Cemeteries in India: On R.P. Jhabvala's Heat and Dust and A New Dominion ", New Literature Review, 15 (1988), p. 19.

${ }^{17}$ E. M. Forster, A Passage To India, intro., Peter Burra (London: J.M. Dent, 1942), p. 282.

${ }^{18}$ David Rubin, "Ruth Jhabvala In India", Modern Fiction Studies 30:4 (1984), p. 682.

${ }^{19}$ Ralph Crane, "Ruth Prawer Jhabvala's Sky: Escape from the Heat and Dust?" SPAN (1987), pp. 178- 189.

20Williams, "Mad Seekers, Doomed Lovers", p. 20.

${ }^{21}$ Suleri, The Rhetoric of English India, p. 2:

${ }^{22}$ Edward Said, Culture and Imperialism (New York: Alfred A. Knopf, 1993), p. 17. 
${ }^{23}$ Paul Scott, Staying On (London: Granada, 1978), p. 8. All further quotations from this work are taken from this edition and are followed by the relevant page number in parenthesis.

${ }^{24}$ Yasmine Gooneratne, "Paul Scott's Staying On: Finale in a Minor Key", The Journal of Indian Writing in English 9:2 (1981), pp. 3-4.

${ }^{25}$ Rudyard Kipling, Selected Poems, ed., Peter Keating (London: Penguin, 1993), p. 35.

26Janis Tedesco, "Staying On: The Final Connection", Western Humanities Review $39: 3$ (1985), p. 208.

${ }^{27}$ David Rubin, After The Raj: British Novels of India Since 1947 (Hanover: University Press of New England, 1986), p. 156.

${ }^{28}$ Salman Rushdie, "Outside the Whale", Imaginary Homelands (London: Granta, 1991), p. 92.

${ }^{29}$ Shearer West, ed., The Victorians and Race (Aldershot: Scholar Press, 1996), p. 70.

${ }^{30}$ Simeran Man Singh Gell, "The inner and the outer: Dalip Singh as an Eastern stereotype in Victorian England", in The Victorians and Race, pp. 68-83. 


\section{Chapter Two \\ Narratives of Enlightenment and European Expansionism}

\section{Introduction: The Enlightenment}

2. Liberation from History: John Berger's G., 1972

3. Empire at Sea: William Golding's Rights of Passage, 1980

4. Deeds of Empire: Barry Unsworth's Sacred Hunger, 1992

5. Oskar Schindler: Thomas Keneally's Schindler's Ark, 1982

6. Anthem for Doomed Youth: Pat Barker's The Ghost Road, 1995

7. Conclusion: European Expansionism

\section{Introduction: The Enlightenment}

As empire expanded from Britain in the seventeenth and eighteenth centuries, expanding with it were the ideas of the moral, social, and intellectual improvement of mankind. A new belief in the capacity to invent and further the self went hand in hand with the spread of commerce and Western discourse and philosophy. The idea of being modern by looking back to the ancients changed with the belief, inspired by modern science, in the infinite progress of knowledge and the infinite advancement towards social and moral betterment. As Jurgen Habermas puts it:

The project of modernity formulated in the 18th century by the philosophers of the Enlightenment consisted in their efforts to develop objective science, universal morality and law, and autonomous art, according to their inner logic. At the same time, this project intended to release the cognitive potentials of each of these domains to set them free from their esoteric forms. The Enlightenment philosophers wanted to utilize this accumulation of specialized culture for the enrichment of 
everyday life, that is to say, for the rational organization of everyday life. ${ }^{1}$

The Enlightenment was thus an intellectual climate that became established through Europe during the course of the eighteenth century. It was part of greater movement under the impetus of empire representing the highest aspirations and possibilities of mankind. The Enlightenment and European expansionism brought a new climate of criticism and debate both within Europe and in the colonies to which it spread. England's Glorious Revolution of 1688 had made it the most liberal and free country in Europe. The rise of meetings in coffee houses, social clubs, and the proliferation of journalism contributed socially and to an expanding notion of an intellectual milieu.

During the Enlightenment period, John Locke's concept of the self as "Tabula Rasa" in which there are no innate ideas and all knowledge is derived from experience was pitted against the rationalism of Descartes for whom concepts of God, Mind, and Body are innate. Locke's empiricism was divided into the two available "sources" of experience: external sensation and internal reflection. The Enlightenment ideal was not simply a method of thought, but the belief in the possibility to change society to bring about a more "enlightened" sense of being, a way of fashioning self and society to give rise to the existence of the conditions necessary for freedom of thought. Locke's understanding was that thought must be spontaneously self-determining and free of emotional determinants from within and institutional pressures from without—only then could it be truly critical and enlightened. The Enlightenment was characterised by a confidence in universal human nature and the controllability and understanding of history and the forces of nature.

During the Enlightenment Locke's ideas became those of fashionable intelligentsia. The novel as art form became the expression of the individual making his or her way in the world. New experimentations in form went hand in hand with territorial discoveries in which literary conventions were measured against imperatives of disorderly realitythe existential understanding was reached that the morally independent individual is made 
up from what happens to him or her. Eighteenth-century heroes and heroines made lifelong picaresque journeys encountering both moral and philosophical problems. ${ }^{2}$

Amongst the Booker Prize winning novels G., Rites of Passage and Sacred Hunger are novels that directly enmesh themselves into the late twentieth-century perspective on the Enlightenment. This perspective, advanced most forcefully by post-modernists, strongly undermines the Enlightenment tenets of transcendental truth, social progress, and objectivity. G. examines the cusp of the Romantic and Enlightenment periods in Europe and, through its philandering protagonist and post-modern montage narrative technique, questions the fundamental philosophical assumptions about the democratic aims for social stability of the Enlightenment era. Rites of Passage constructs a dialogue between late twentieth century perspectives on the Enlightenment and the current fashion of post-structuralism and post-modernism. The narrative quests for truths and underlying absolutes are interrupted, denied, and evaded by the turn of events and the complexity of language in portraying them. Schindler's Ark and The Ghost Road, by comparison, concern themselves with issues of European expansionism and with the complex crises of identity that arise in Europe after the retrenchment of empire following the First and Second World Wars.

John Berger's $G$. is in many ways the most unusual of the Booker Prize winners. Written by a Marxist post-modernist, $G$. ostensibly explores the sexual adventures of the illegitimate son of an Anglo-American heiress and an Italian merchant who philanders, Don-Juan-like, amid the political and social turmoils of Europe at the turn of the nineteenth century. $G$. concerns the Marxist preoccupation with the failure of people to reach their potential due to the unegalitarian structure of society. It is also an ironic register of the changes in climate of social opinion after the sexual revolution of the "swinging" sixties and the failure of capitalism universally to deliver the social goals and freedoms that it espouses economically. The staccato narrative of $G$. and its brief chapters and line drawings purposely interrupt the stable narrative of the novel and introduce post-modern elements of rupture and free-floating signification. There is a tendentious irony to $G$. in so far as $G$ attempts to evade history at every turn, to avoid 
the consequences of his social interactions and to avoid the wider political movements that consume those around him. His evasions bring him to the attention of the secret police, he is mistrusted by all parties and is disposed of as a threat. Thus the novel is post-modern in both style and theme, harbouring a Marxist critique of the Englightenment pursuit of social betterment and the value of absolutes and fixity over change and subjectivity.

Alluding to Van Gennep's anthropological work of the same title, William Golding's Rites of Passage interweaves epistolary and journal-entry narrative styles in a seaadventure story of a young gentleman's "rite of passage" into both manhood and a new life in Australia aboard one of Britain's "wooden walls", the ship Britannia, at the cusp of the Enlightenment and post-modern eras. Golding's novel is one of transition: Talbot, its protagonist, moves from youth to adulthood by way of moral development; the ship passes from the old world of Britain to the new world of Australia. Golding explores themes of class value, sexual misadventure, and the amorphousness of history. Empire is represented by the ship itself, The Britannia, and its passage into the new world, the cusp of Talbot's passage into adulthood. In constructing its alternative discourses, this post-modern novel, which is a pastiche of the picaresque novel of the Enlightenment, argues that there is no position outside culture, or more specifically the culture of the discourse that comprises the worlds that the novels create from which to view culture. It is also as if Golding, like John Berger in $G$., comes to the realisation in his novel that it is not possible to use language to step outside language. There are no privileged positions, no possibility of absolute transcendence; there is no conceptual space not already implicated in that it seeks to contest. For the characters, as for the reader of Rites of Passage, internal disruption becomes the only method of reality checking: fragmentation, irony, micro-politics, language games are prevalent and the stable narrative is undermined by surficiality or historical pastiche.

Barry Unsworth's Sacred Hunger, like William Golding's Rites of Passage is a seaadventure story which explores the expansion of early empire into the trade triangle of Britain, the Caribbean and New World. Sacred Hunger entwines the lives of two 
cousins, Paris and Kemp, and dramatises their rivalry of ideals: one mercenary, one humanitarian; one representing Enlightenment values and the other a Romantic. The novel explores the tension between the Enlightenment confidence in progress and emancipation on the one hand, and the brutality of materialism and exploitation on the other. The prologue announces the background theme of the novel in the desire to explain the presence of the "paradise nigger" or mulatto, the hybrid who can quote English verse. The plot, which sees a crew mutiny in a way similar to the mutiny of the Bounty, serves to explain the presence of this captivating drunkard at one edge of empire's reach and emphasises the Enlightenment preoccupation with nativism and slavery.

\section{Liberation from History: John Berger's $G$.}

"Never again will a single story be told as though it were the only one." John Berger, G. A Novel. ${ }^{3}$

The fourth Booker Prize winner, G., is also John Berger's fourth novel after A Painter of Our Time (1958), Permanent Red (1960), and The Foot of Clive (1962). Like Berger's earlier novels, $G$. is concerned with the desire to transcend the limiting conditions of bourgeois society, to liberate the self, and to achieve human potential without isolating the individual from social responsibility or engagement. As Joseph $\mathrm{H}$. McMahon puts it: "[w] hat is noteworthy about Berger is the intensity of his personal effort to study the chasm between the ideal perceived and reality attained and to propose possible ways of bridging it." 4 The history of turn-of-the-nineteenth-century revolutionary Europe is re-written as $G$. contrasts three major strands of class structure: an ascendant bourgeoisie (largely capitalist and industrialist, from which G. is illegitimately descended), a declining aristocracy, and a working class largely portrayed as victims in the novel. As Kiernan Ryan suggests, Berger's novel undertakes an "epic 
investigation of the process whereby a qualitatively different order of being evolves and erupts within the ossified dominant structure of social relations. . . . What it seeks to project is nothing less than the first great liberating surge of energy towards social and sexual renewal galvanising Europe at the dawn of the century. . . ."5

The novelty of $G$. lies in the formal experimentation of its narrative. The text is composed of a staccato montage of three narratives interspersed with primitive line drawings which are of a sexual nature. Berger uses these drawings to comment on the process of historical construction. Three styles of narrative are juxtaposed in the novel and are interconnected with the themes of transience and anonymity, experienced with particular cogency by the protagonist, G. The main descriptive narrative is detached, clinical, visually penetrating. This narrative is intercalated with a similarly detached narrative which depicts and analyses the historical and socio-political events which $G$ encounters or which occur in a particular country, city or at a given stage in his life. The third narrative style reveals the intimacies of G's childhood. This narrative is sensual as well as psychologically engaging. The line drawings a provide another dimension to the reading experience, collapsing public and private contexts and making the reader selfconscious about the psychological states that are engendered between reader and page. All three narratives are written in the third person except when the "author" interjects selfconsciously from time to time to remind us that these are his words we are reading, that the novel and G's story are his construction.

The juxtaposition of these three narratives serves both to distance the reader from the characters (stressing their construction as fictitious), and to accentuate the socio-political, historical construction of the characters within a novel which makes the ideological functioning of such construction one of its principle themes. It is the plot of historyand G's attempts to avoid and evade it-that provides the main thematic tension of the novel: "[i]t is her independence that he loves. She travels anywhere to meet him. She reads the history of the place before they arrive" (8).

For half of the narrative $\mathrm{G}$ is given no name. He is abandoned by his parents, the novel opening with a description of "the father of the principal protagonist of this 
book"-who cannot acknowledge $\mathrm{G}$ as his son for reasons of social convention (3). "The mother of the principal protagonist" is unable to reconcile being a single parent with her Fabian politics (5). Thus $\mathrm{G}$ is introduced obliquely. He is removed, apart, exiled from the major events and people that shape his society. As McMahon puts it, "G. incarnates the text envisioned as praxis, and that praxis is put forth as a manifestation of how proper arrangements of events and the motives behind those events can reveal that the forces needed to change history are already present in, though not yet at work on history." 6

$\mathrm{G}$ is an escapist and an escapee. Seeking to detach himself from society, he also seeks to detach others. As Ryan puts it, "he is susceptible to strategic amplification into a paradigm of desire in general, becoming in fact the symbolically condensed essence of all the interrelated forms of awakened appetency electrifying Europe."7 G seeks liberation from the world of bourgeois normality so as to identify and free the "Other", to push himself and his lovers to the limit of their sexuality. In a world in which people are constricted and constructed by political events and ideas, G remains uncommitted and apolitical. As others are swept up in demonstrations, assassinations, rebellions, and skirmishes into "the world as a field of conflicts . . ." (203), G seemingly remains removed. Sex is G's ostensible motivation. As A. R. Bras puts it, "[a]s others use a grenade or bomb to achieve their individual or collective goals, he uses sex. His cock is his strategic weapon, his means of liberating the other." 8

G's detachment, his apolitical stance in a politically polarised world, is born of a supreme indifference which is ultimately his undoing. Apolitical, $G$. is also ahistorical. $\mathrm{G}$ seems to be independent of time. He slips between the narratives of history, unrecorded (except of course by the author, Berger) and unrecording. Implicit in Berger's narrative is the impossibility of remaining neutral in a political world. Neutrality is mistaken by all sides as complicity. $\mathrm{G}$ dies at the hand of an anonymous mob while performing a task for Britain's Foreign Office in Trieste, a task which he agreed to undertake out of boredom. Because Trieste is politically conscious, G's presence there 
gains a political import. Despite his indifference (or perhaps because of it) to any political affiliations, he is implicated in all, mistrusted by all, his existence made political.

As Bras points out, $G^{\prime} s$ sub-narrative is essentially realistic. In describing a politicised Europe, with a narrative of clinical precision and objective observation, the novel contrasts human reality with its egalitarian potentiality. However, as Bras notes, Berger "shows the real, and by exposing its abominable shortcomings damns it, but he systematically fails to outline the potential." 9 G's death signifies the impossibility of remaining apolitical. $G$. demonstrates that it is ultimately impossible to remain outside history, or outside the history and politics that G. hopes to avoid, remain indifferent to, and go unrecorded in. To live is to form a narrative, perhaps many narratives, and take part in others. Yet the egalitarian potential of society remains unarticulated in the novel, which cannot move beyond the figuring of history as it always is. As Bras puts it, "In other words, why does an author who believes that the artist's main function is to increase men's awareness of their potentiality, fail to show the reader what would be the implications of his living in a society in which he attained his potential?"10

Perhaps the answer is that Berger is a non-utopian Marxist who points to the stifling of the individual by bourgeois socio-political and historical conditions and the consequent inability of human potential to be reached. As McMahon puts it:

Behind Berger's examination of these issues there is a presupposition that three kinds of social living are possible though not equally desirable. The first is the feudal model which has been frittered away and lives on only in certain rituals that have maintained their liturgy but have lost their capacity to generate any saving grace. The second is the bourgeois world, which he envisions as the world of theatre and which is life-denying in several ways; it creates the possibility of a G.; it subordinates women and turns them into possessions; it constructs its society on the exploitation of the great mass of men and women so that even its own managers become trapped in inauthentic ways of life. The 
third is the world à revére - to dream about or to dream up . . . -and it is a world that would eliminate Don Juans by effecting the fusion that would bind sexual energy and revolutionary prospects indissolubly in the services of each other. ${ }^{11}$

Time is altered not only within the story of the present in the text, as some histories are subjective and others clinical documentations of objective historical events, but also for the reader as he or she "writes" the text through the act of reading. Berger's inference that politics is inescapable in language and in life correlates with his portrayal of history as arbitrarily constructed and yet necessarily interwoven with politics. In $G$., Berger does not seem to be implying that history is false (that certain events did not occur in such a place at such a time) or unknowable, but that the events are constructed by how they are written and read, and this act of writing and reading involves a political component that permeates all our thoughts and actions as a consequence of making choices. He is also showing the limitations of the 1960s stress on absolute sexual freedom.

$G$. also then explores the limits of metanarrative, the construction of history from a single overarching view point. Berger's sense of history is contemporary, subjective, phenomenological. As he puts it:

All history is contemporary history: not in the sense of the word, where contemporary history means the history of the comparatively recent past, but in the strict sense: the consciousness of one's own activity as one actually performs it. History is thus the self knowledge of the living mind. For even when the events which the historian studies are events that happened in the distant past, the condition of their being historically known is that they should vibrate in the historian's mind (54). 
Berger's argument for the potential of man through social equality, and his Marxist frustrations with class structure and the ills of bourgeoise capitalist values are complex and seemingly contradictory. Just as his belief that certain experiences (sexual in the case of G) give access to a "reality" beyond that of ordinary experience sits uneasily with an element of puritanism in his writing, $G$. explores the dialectical relationship between modernity and post-modernity. On the one hand, he seems to affirm a kind of utopian pursuit of progress and on the other a post-modern regard for the relativism of voice, class and value. Perhaps it is the utopian nature of his Marxism that enables him to reconcile these apparently contradictory threads. Berger struggles in $G$. under the mantle of a Marxist post-modernism. Narratologically he engages in the totalising process that he is ideologically oppossed to. Furthermore, the collapse of subjective and objective worlds render a transparency in language that works against the novel's ability to generate a convincing alternative context or "fiction". As Mazurek puts it:

Berger works through a method of totalization, in which the 'objective' understanding of a social system provided by historical analysis is 'grasped more surely' only when it becomes human, livedwhen the 'subjective' feelings and values through which the system is experienced are articulated. But this process is never complete, nor does Berger pretend that the totality of social relationships is ever fully grasped by a single method or account, for his account is itself contained within the relations it describes. ${ }^{12}$

Every discursive act of inclusion is also one of exclusion, and it is not possible to include what is excluded. Structured around a paradox, Berger's $G$. is a critique of the politics of oppression, be they related to race or class. Marxist in inclination, the novel questions all ideological discourse. Finally $G$. is a criticism of the failure of humans to seek new ways of seeing other than by seeking transcendence of history and language. To this extent Berger's stress on the liberational value of Marxism works with post- 
modernism and its affirmations of freedoms and disavowel of underlying truths and absolutes. However, in advancing the Marxist argument Berger generates in theme, if not in style, another of the grand narratives that post-modernists refute. $G$. explores the nature of illusion and power, the relationship between fiction and history. As McMahon puts it, "in general terms his engagement is a comment on the unacceptability of any political order which cannot deal with men's nature and needs and which, incapable of doing that, urges men to support, always inauthentically and sometimes miserably, the order which mutilates them." 13 The Kafkaesque ending as $G$ is struck on the back of the head by an anonymous mob and dropped feet first into the salt water of Trieste harbour comes as somewhat of an odd, theatrical finale enacting a sense of closure as "[t]he horizon is the straight bottom edge of a curtain arbitrarily and suddenly lowered upon a performance" (316).

\section{Empire at Sea: William Golding's Rites of Passage}

The first novel in William Golding's "To The End of the Earth" seafaring trilogy, followed by Close Quarters (1987) and Fire Down Below (1989), Rites of Passage won the Booker Prize in 1980. Rites of Passage continues themes familiar in Golding's earlier fiction-the British class structure, chaos and creationism, determinism and free will, anthropomorphism, the limits of post-structuralist discourse, good and evil-and also offers a post-modern interpretation of the historical novel.

In Rites of Passage, Golding engages in metafictional play. The novel takes the form of a journal written by its chief protagonist, Edmund Talbot, addressed to his aristocratic patron-godfather on a voyage to the "new world" of Australia at the dusk of the Enlightenment period and the dawn of the Romantic. The journal contains, in Talbot's own words, an account of his voyage aboard the unnamed ship (presumably Britannia). Talbot's narrative switches in ironic confusion from the mode of "Enlightened man of reason" to "Tarpaulin", his name for the demotic language-code of the crew. The narrative also records the letter of Robert Colley, a parson of the Church of England, 
who after a fit of drunken religious fervour performs fellatio on a seaman, and thereafter retreats to his cabin where he dies of shame. The incorporation of Colley's letter into Talbot's journal as an act of "natural justice" draws attention to the subjective quality and thus the inevitable unreliability of Talbot's account. It also demonstrates Talbot's newfound moral sincerity. This event provides the climax of the novel which chronicles a British class structure in microcosm on board one of empire's "wooden walls".

Golding's concern in Rites of Passage is in part to explore the limits of narrative in a blurring of the boundaries between the objective and the subjective, the realistic and the fantastic. Talbot's diary, which begins in an objective tone, thereafter becomes more subjective, as the narrator "adjusts" to the confinement of life aboard the ship. The chronology of the narrative breaks down and chapter numbers become letters and Greek words and numerals - this in symbolic disintegration of a modernist chronology. The attempt to document the progress of the ship and Talbot's experiences on board soon dissolves into interior monologue, with Talbot gradually learning the "sea language" of the crew, and readjusting his upper-class affectations. As J. H. Stape puts it:

The trilogy itself destabilizes narrative authority by relentlessly opposing two competing discourses: documentary and spiritual autobiography. The first immerses the reader in a precisely observed external world, the second in the narrative from 'below' registering a range of motive and sentiment that is necessarily partial, incompletely observed, and only intermittently comprehensible. At the outset these discourses appear wholly antagonistic, but they increasingly merge as Golding argues the impossibility of maintaining distinct and discrete boundaries. 14

Golding's novel chronicles the shift between the Enlightenment and Romantic periods, and Talbot experiences this shift in metaphorical parallel with the contemporary shift between modernism and post-modernism. Colley is (like Talbot himself in a different 
guise) a construction of and comment on British class society: "In our country for all her greatness there is one thing she cannot do and that is translate a person wholly out of one class into another. Perfect translation from one language to another is impossible. Class is the British language." 15 Thus the familiar theme of a scathing comment on the ills of class structure, so malevolently voiced in Golding's earlier novels The Inheritors (1961) and The Pyramid (1967), is voiced again in Rites of Passage. It is summed up in the irony of the phrase repeated throughout the novel, for which Talbot cannot find an exact translation: "Noblesse Oblige" ("the nobles are obliged") but in Golding's novel of shiplife his characters show little nobility and even less mutual obligation. Colley is castigated by Captain Anderson and mocked by the crew, and recognises that he himself is "without the sartorial adornment of my calling, mistaken for an emigrant!" (223) Of the passengers only Talbot addresses him with any politeness. It is not clear from the narrative at what stage Colley recognises his indiscretion, however it is ironically clear that he does recognise it from the disparity of two alternative accounts of his behaviour. The first is "fanciful" and filled with fervent religiosity: "I abdicated freely and yearned to kneel before him. My whole heart went out in a passionate longing to bring this young man to OUR SAVIOUR, first and surely richest fruit of the harvest I am sent forth to garner!" (218) The second is more foreboding, Kafkaesque and dreamlike as the parson is forced to undergo an initiation ceremony or rite among the crew as the ship crosses the equator:

What a man does defiles him, not what is done by others. My shame, though it burn, has been inflicted on me ... I was made to kneel before the "throne" with much wrenching and buffeting ... Yet as I opened my mouth to protest, it was filled with such nauseous stuff I gag and am like to vomit remembering it ... this operation was repeated; and when I would not open my mouth the stuff was smeared over my face. The questions, one after another, were of such a nature that I cannot write any of them down (237). 
Colley's death, as well as iterating Golding's theme of class division, emphasises also that of the division between the sacred and profane. Colley's rite of passage is a retrograde one which is consequent on his inability to sustain his (dis)position in the structure of the society aboard the ship. Golding's intent is to criticise the society that constructs his death. As Arnold Van Gennep puts it in the book from which Golding presumably takes his title: "for a priest to be unfrocked calls for ceremonies, acts of a special kind, derived from a particular feeling and a particular frame of mind. So great is the incompatibility between the sacred and profane worlds that a man cannot pass from one stage to the other without going through an intermediate stage."16

Colley's act of fellatio is thus an ironic parody of the passage from Van Gennep's text. The motif of border crossing or boundary marking abounds in the novel: the line across the equator, one narrative mode into another, the line on the ship's deck which marks the crew's territory and is forbidden to the passengers. Colley's act is a rite in reverse: instead of gaining power he loses it, and with it he loses the will to live.

The black comedy of Colley's circumstance is reinforced by the disparity of his two readings of it. Golding gives us a multiplicity of accounts for Bill Roger's surprise at getting "a chew off a parson!" (273) As James Gregor and Mark Kincaid-Weekes point out there is a double idiom in the novel: "Talbot's late Augustan idiom of Taste and Enlightened Good Sense, Colley's Romantic idiom of the man of feeling."17

Golding's scepticism about the anti-representational claims for language does not rest on Talbot's recognition of an inability to see all events aboard the ship as they are; Colley's death (the "death of the author" of Colley's letter) signifies a lacuna or aporia in the text for which there is no obvious explanation. Talbot himself, privy to both reported events and Colley's letter, can only state: "In the not too ample of man's knowledge of Man, let this sentence be inserted. Men can die of shame" (278). Colley's death, apparently by this shame, is not explained in the novel, and the reader, like Talbot, is left only to presume that the emotional life of the parson caused it. The lack of explanation offered by Golding opens up a dilemma in the text that remains unreconciled. 
Talbot's own reaction is firstly one of naivete tempered with compassion in the light of Colley's death. Golding thus breaks up the metanarrative of Colley's shame with the micronarratives of multiple perspectives and interpretations. The shame itself and the unexplained death of Colley represent the textural aporia, the unexplained, that purposely disintegrates or interrupts the uniformity of what is initially an epistolary sea-narrative. The surface of the sea (narrative) is interrupted by Colley's body entering into it. This represents the only such "break" in the surface of the novel, and is closed again by Golding's invocation of Shakespeare. Plumbing the depths of one narrative leads to the hidden depths of another: "The mortal remains of the Reverend Robert James Colley shot from under the union flag and entered the water with a single loud phut! . . . So the remains of Colley dropping 'deeper than did ever plummet sound' were to be thought of as now finding the solid base of all" (262).

While Colley's death has symbolic meaning at the textural "surface" level of the novel, breaking up the seamless narrative of the sea/story, it also has the thematic significance of precipitating Talbot's moral development and increased awareness of the effect of a class structure and his place within it. Talbot begins his voyage affected, pompous, ignorant, and ends having learned a little more about himself, seafaring, and society.

Golding uses dramatic technique by employing a post-modern metafictional or "grotesque" reading to disrupt the reality of the narrative. The grotesque mode has a similar function in pointing to the anti-representational quality of language, the "reality" that will never stay put, the vision that is forever distorted and troubled, the fear inspired by the unexplainable:

Golding's vision provides another chapter in the examination of the dissolution of western society; it does not comment on the ultimate truth of the religious perspective, nor does it posit an Absurd perspective $\quad .$. Instead ... [i]t directs action 'realistically' to a situation in which neither of these views has an operational function . . . [t]he ludicrous is combined with the pathetic, hideous evil with 
triviality, and every sacrifice, including martyrdom, tends toward selfserving melodrama. ${ }^{18}$

Golding's grotesque prose deposits Colley in the sea, marking the end of his narrative, the death of "God" in the secular world of the ship. Golding depicts a universe in microcosm in which it is difficult to sustain belief in any form. The larger narrative is his attempt to wrestle with the structure of reality that can never be truthfully recorded. The form that the narrative (be it Talbot's or Colley's letter to his sister) attempts to impose on a reality that is ever changing or distorting in grotesque images, characterises the anti-representational quality of language, its inability to grasp and pin down anything with absolute fixity and clarity. Colley's death marks the end of the pursuit of Godly "essence" outside the text, from there on we are in the realm of metafiction and postmodernity: As Talbot says: "Life is a formless business, Summers. Literature is much amiss in forcing a form on it!" (265)

Rites of Passage is not quite a novel of colonisation. Rather it is a novel that wanders to the "edge" of empire. Here empire's edge is located at the point of breaking of the single metanarrative. The novel metaphorically invokes the rhetoric of empire, a language stretched over the geography, or written on the subject that it can no longer cover. The rite of passage that the novel attempts to perform is the act of border crossing. Events transpire that encourage the crew and passengers of the ship to undergo rites of passage as they approach the new world, as the reader is forced to undergo the transition between modern and post-modern discursive worlds. It is a movement or transportation not from, as with Van Gennep, the profane to the sacred, but from the sanctity of knowing to the knowledge of uncertainty. For Colley, these rites become grotesque social blunders and occasions of ridicule; for Talbot, they are rites of passage from innocence to experience, moral superficiality to meaning; they are the rites of passage that the British community must undergo when taken to the edge of its influence. For the reader, as for Golding, the metadiscourse of the novel undergoes a rite of passage through language, exploring the limits of what a fiction or multiple fiction is able to 
describe. While language can describe illusion, it can also conceal it, the unseen is the act (symbolised by Colley's death or act of fellatio) beyond the text for which there is no representation in language-that which is unexplained and unexplainable. As Talbot, Anderson, and Colley's ship progresses across the line of the equator to the new world of Australia, it takes with it this void or lacuna in the text, an overstretched and inconsonant alphabet: "Long live illusion, say I. Let us export it to our colonies with all the other benefits of civilisation!" (123)

\section{Deeds of Empire: Barry Unsworth's Sacred Hunger}

As Greg Dening puts it in Mr Bligh's Bad Language (1992), "Space and the language to describe it make a ship."19 Barry Unsworth's 1992 Booker Prize co-winner Sacred Hunger is redolent with a language that creaks with the ebb and flow of historical narrative. Unsworth's sixth novel, Sacred Hunger is set in two narrative parts, the first in the period between 1752 and 1753 and the second thirteen years later in 1765, telling a seafaring story loosely constructed on the theme of the mutiny of the Bounty. The story concerns the rivalry of Erasmus Kemp, the son of a Lancashire sugar and shipping merchant, and his cousin, Matthew Paris, surgeon and scholar imprisoned for denying Holy Writ. Kemp has a childhood hatred for his older cousin, Paris, who on their last meeting "lifted him, helpless and raging, away from a dam he was trying to build against the sea." 20 A lingering dislike for the exercise of his cousin's will over his own remains with the younger man. The fates of the two cousins are again entwined thirteen years later when Paris is sent as ship's surgeon on a vessel destined for the slave trade of the West Indies on which Kemp's father's flagging fortunes are rested. Kemp is shown as resentful and hypocritically disparaging of his cousin's imprisonment for denying Holy Writ, despite his father's investment in him on the Liverpool Merchant.

Sacred Hunger is framed by a prologue and epilogue concerning an account by Charles Townsend Mather of the "paradise nigger" mulatto, Luther Sawdust, who in 1832 is begging on the water-front streets of New Orleans. The story of the novel is the 
"history" of the paradise nigger, so named because, when drunk, he talked "of a Liverpool ship, of a white father who had been doctor aboard her and had never died, a childhood of wonders in a place of eternal sunshine ... a settlement where white and black lived together in perfect accord" (1). According to Mather, in the Mississippi Recorder and later in a chapter entitled "Colourful Characters of the Waterfront" in Sketches of Old Louisiana, we learn that Luther could read and quote refrains from Alexander Pope. Mather himself is recorded as a colourful and visionary character, dying in a Jacksonville sanatorium in 1841.

Sacred Hunger has a complex narrative structure. It is fiction within fiction within fiction-the plot expresses Unsworth's desire to explain his invention of the mulatto's self-invention: "But the mulatto haunts my imagination still, with his talk of a lost paradise, raising his blind face to solicit something from me. Nothing can restore him now to Mather's text, but he sits at the entrance to the Labyrinth of mine...." (2) While Unsworth frames his historical text with the mulatto, this framing device is the only attempt to make fictional reference self-consciously in the novel.

Sacred Hunger does not concern itself overtly with the epilogues, asides, and intrusions of the author that characterise the post-moderism of, for example, G. or Rites of Passage, but rather with the genre of historical seafaring yarn exemplified by authors such as Robert Louis Stevenson and Herman Melville. However, the novel could be said to fit loosely into the category of British historiographic metafiction with its combination of self-reflexivity and, in this case, fictional "historical" underpinnings, which are linked to a discourse of imperialism and the Enlightment. Imperialism is portrayed in Sacred Hunger in two ways. Firstly, it is represented as literally the frontier of an expanding commerce, the Triangular Trade: "-cheap trade goods to Africa for the purchase of negroes, these then carried to America or the West Indies and sold there; rum and tobacco and sugar bought with the proceeds and resold in England" (17). Sacred Hunger also deals with the Enlightenment concern with the "ideal" of racial justice and egalitarianism embodied in the allegory of the mutiny of the Bounty, a return to a mythical lost 
innocence. It is only in the epilogue that we learn that the paradise nigger is the mulatto son of Paris.

Two stories are thus told simultaneously in the narrative. There is the historical adventure story of the fate of the Liverpool Merchant as slaves are taken on board in the West Indies, the mutiny on board the ship, the establishment of an alternative "Pitcairnlike" community of blacks and whites in Florida, and thus the abandonment of the civilised imperial system for one of outlawed egalitarianism. There is also the story of the rivalry between the two cousins (the first mercenary, the second scholarly) pitting ruthless imperial exploitation against compassion and enlightenment, a rhetoric of materialism against one of idealism. Sacred Hunger subsumes these two interweaving themes within a seafaring narrative interspersed with Paris's diary entries and the later selective re-reading of them by Kemp who funds a ship to Florida to discover the fate of the Liverpool Merchant and its crew.

While such inferences of the post-modern condition in the text are discernible if we look at each text in terms of narrative construction, Unsworth's novel also from its historical setting displays aspects of post-modernism which originate in the Enlightenment era and the rise of empire. The character of the mulatto in Sacred Hunger explores the fictive origins of the hybrid "post-colonial" type, and has its historical corollary in the figure of Friday Fletcher Christian, son of the mutinous Bounty's Pitcairn Islander. As Thomas Docherty puts it:

While operating as a critique of a social formation, the novel orientates the reader through the point de repere of the recognizable character . . . The character, as our way into the hypothesized world of fiction, becomes its main message too. It would be clearly fallacious to suggest that 'character' did not appear in writing prior to this historical moment; however, it was only during the Enlightenment that it came to have this central, organizing dominance as the model for 


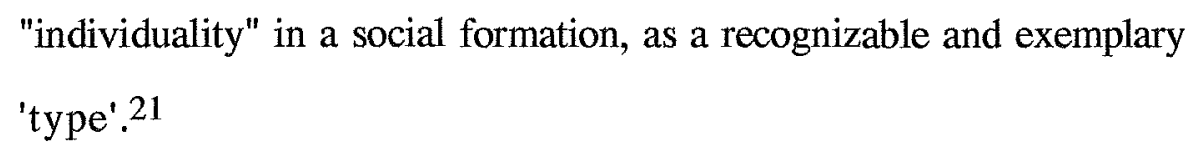

While the chief protagonists of Sacred Hunger, Paris and his cousin, Kemp, are the binary agents of the Apollonian and Dionysian principles, the novel in effect arises from the author's self-proclaimed desire to explain the "presence" of the hybrid mulatto character, the "paradise nigger" of the novel's prologue. The character of the mulatto evokes the fictive origins of the colonial hybrid as a type which has its historical underpinnings in Friday Christian Fletcher, the Pitcairn descendant of mutinous Fletcher Christian of the Bounty, or in fictional terms, in Jean Rhys' Bertha of Wide Sargasso Sea (1966). In this historical context it is significant that the mulatto of Sacred Hunger surfaced in the Enlightenment period and during the transitional phase between the Enlightenment and Romantic periods, the time also in which Golding's Rites of Passage is set. A link is thus forged between the concept of a post-colonial type and the representation of a historical condition of post-modernity. As Docherty puts it:

The age is also, crucially, the age which saw the invention of a specific category of primary relevance to character in the novel, for it was during this century that the concept of 'human nature' was invented. Foucault has argued that 'man is only a recent invention, a figure not yet two centuries old, a new wrinkle in our knowledge [who] will disappear again as soon as that knowledge has discovered a new form' (Foucault 1974:xxiii). The delineaments of this new form are now being traced in postmodern modes of narrative and characterization. ${ }^{22}$

Foucault's reading of human nature as "not yet two centuries old", by which he means the Enlightenment construction of the concept of human nature, currently explored in post-modern narratives and characterisations, is coeval with a recognition in historical 
texts of the "consciousness" of humans: the ability to divorce and distinguish the ontological status of humans independently from the constructions of history. In this reading humans become the controllers of their own historical vessel, rather than left to the whim of the winds and tides of history, a moment perhaps coterminous with Enlightenment consciousness. At the same time, the metaphor of Enlightenment provides a cultural and theoretical justification for the excesses of imperialism in which the colonial impulse is justified by the enlightenment of the colonised:

The construction of 'human nature' in the eighteenth century went hand in hand with the supervention of antiquity: it represented the 'ancients' winning the 'battle of the books' and the battle of competing philosophies against the 'moderns', and thus was a major defeat of 'modernity'. The ancient tradition, in the form of a continuity hypothesized from antiquity, suggested that the present, eighteenth century state of affairs and state of understanding had always been the case. To this extent, it was supposed to be natural, non-secular or nonhistorical. The concept of Enlightenment, that very metaphor, enacts the trope which is axiomatic to the novel and its characters, for it claims simply to render visible a latent nature that has always been there. The corollary of this, of course, is that there is an essential nature which is located in the human being which makes him/her able to be in conformity with the wider "natural environment", or social formation. ${ }^{23}$

Thus the eighteenth-century or Enlightenment philosophy, while in some senses a defeat of the "moderns" in positing a construction of man "backdated" since antiquity, is itself inevitably caught up in the very paradigmatic historical shifts that it attempted to replace. The point is that there is a conflict between essentialism and the de-centred subject of language. The interdependence and deferral of meaning of post-structuralism 
work against the idea of a unitary and stable subject. Where the Enlightenment differs from the post-modern is in its presumption that there is an essential nature located in the human being. Post-modernist intellectuals, perhaps more so than at any other point in history, would posit that there is nothing essential to locate. Multifaceted selves replace an essential self. Claudia in Moon Tiger cannot recall stable linear narrative to her history, or an essential self, but recalls a myriad of subjective selves.

The Enlightenment era was coeval with the rise of empire, and the philosophies of the Enlightenment were those that supported imperial "white" world domination in the cause of humanist advance. The idea that man is always and everywhere the same fundamentally became licence for the hegemonic impulse of empire, for a form of racism. Humans were deemed be the "same" in the image of white man and empire; the colonised had to be enlightened into the condition of white man, "man's Other" to be brought from darkness into Enlightenment. The hold of empire on the English language contributed to this condition.

Sacred Hunger is a novel which explores, like Dening's Mr Bligh's Bad Language, the relationship between perceived justice and natural justice; whereas the one deconstructs the myth of the mutinous Bounty (the myth of authoritarian physical violence), the other constructs the myth of co-habitation in fictional Florida that Fletcher Christian's crew experienced on Pitcairn Island.

The language of authority and subordination is pervasive in both Unsworth's novel and Dening's anthro-history of Bligh. The pidgin English of Paris's Florida community strikes a parallel with the language of Pitcairn. As Paris reflects, "What gave us the confidence to suppose that a state of nature could only mean what it meant to us, a notion of Eden, a nostalgia of educated, privileged men?" (541) In fact, Paris's privileged nostalgia was shared by the mulatto, his hybrid son. The language of Pitcairn was English enough to be recognised and understood by the later visitors to the Island but was oddly transposed into an "English" language of power and an everyday language of Tahitian. 
Like the women of the fictitious castaway Florida community, the Tahitian women of Pitcairn Island have a strong influence over the men. Both communities suffer a certain amount of disintegration as men fight over or share women. Ultimately, this, rather than the intervention of an outside presence (as in Unsworth's novel) is, according to Dening, the undoing of the initial mutineers of Pitcairn Island. However, unlike those of Unsworth's novel, the resources of land were not shared by the white population of Pitcairn Island. Ultimately, after much in-fighting on the island, John Adams was the one remaining literate on Pitcairn, the only remaining male, and the Bible the one remaining book. Like Paris and Kemp's Florida community of mixed races, Adams' community was:

Genesis all over again. Adam's last man on earth on his isolated island, was Adam, the first man. Pitcairn was the Garden of Eden because the Word in the form of the Bible was unmeditated by anything other than Adams' innocence . . . The Bible was the prime source of divinity itself. It offered unpolluted wisdom. There was no knowledge of good and evil, no knowledge of laws ... on Pitcairn sin had no name. Obedience, repentance, loneliness created their own evolutionary force. By this, heredity, prejudices, isolatry, cruelty were bred out of existence. Discipline, not laws, made paradise (333).

However, Adams' Pitcairn was no more Genesis than Paris's, presuming for a moment that a return to such apparent innocence has its origins, from Defoe's Robinson Crusoe (1719) onwards, in the romantic Western vision of an "island and a Bible". Often contact with the "Other" was a kind of mirrored contact with the "Other" within, differences within cultures were not addressed but the white coloniser was brought up against an image of him or herself, rather than engaging in meaningful dialogue with the culture of the colonised. Western surveillance enforced a distance between the onlooker and the subject surveyed. 
Like the "sacred hunger" of Unsworth's novel, the "bad language" of Captain Bligh in Dening's anthro-historical narrative is concerned with the construction of history. History and how it is seen is a matter of the attention of competing narratives. The individual is as much constructed by language as he or she is a constructor of the world through language. Thus, the concluding interchange between Kemp and Paris:

\footnotetext{
'Your stay in the wilderness has unsettled your brain,' he said. 'You must be mad to make such comparisons. Thurso was set in authority over you. He was engaged in lawful trade. These people are fugitives on the one hand and chattels on the other. I have proceeded at every step with total legality. I have a warrant from the Governor of Florida.'

'Useful thing, a warrant. Murder and theft change their names if you have one. I suppose the Governor himself was armed with one when he took Florida from the Crown?' (617)
}

Kemp's legalism blinds him to the rhetoric of injustices committed in the name of imperial justice. His refusal to put people over possessions is belied by Paris's cynicism and mutinous rejection of such a system. The negotiations of power by the two do not fit the traditional pattern of oppressor and oppressed, however, for Paris refuses to submit to the notion of Kemp's authority. Kemp, like Bligh, is overdetermined by his rhetoric, Paris underdetermined by his inability to articulate a viable alternative given the social conditions and constraints of the time and his own moral ideals. The hunger of Sacred Hunger is not just literally that for food and shelter, as experienced through the insatiability of empire or the needs of West Indian slaves, but for a moral sense of communality or justice in the human condition. Like G., The Conservationist, Rites of Passage, and Moon Tiger, Sacred Hunger narrates the spread of empire to the ends of the Earth. In so doing it explores the range and ambivalence of human action and experience under conditions of change, the transgression of private and public spaces and concerns, 
the collapse of politics into sexuality, the limits of history and language, and the redefinition of peoples, ethnicities and territories as empire expands.

\section{Oskar Schindler: Thomas Keneally's Schindler's Ark}

Thomas Keneally won the Booker Prize in 1982 for his historical novel Schindler's Ark. Based on the wartime exploits of flamboyant Sudetan-German industrialist, Nazi-Party member and "scoundrel-saviour" Oskar Schindler, who shepherded his Jewish workers through the Nazi extermination programme by means of bribery and cunning, the novel caused controversy in taking the award for a prize in fiction in spite of its overtly factual conception and content. This stylistic ambiguity in the novel, which blurs the genres between fiction and fact, becomes also a thematic ambiguity that pervades Oskar's motivations and provides both the tension and dramatical interest of much of Keneally's writing.

Michael Hollington in "The Ned Kelly of Cracow" reads Thomas Keneally's Schindler's Ark as an idiosyncratically Australian literary product: "For all its detailed, documentary striving after an accurate realistic portrayal of wartime Poland-running to maps of Cracow, and plans of the concentration camp-Schindler's Ark is a peculiarly Australian book, owing more to the mythology of the bush than to that of central Europe."24 Hollington supports his argument through a brief analysis of Schindler's character. Schindler is a composite of many Australian characteristics and ideals: a philosophic innocent, an anti-intellectual, a gambler, an apolitical capitalist, a pragmatic entrepreneur, anti-ideological rather than protestory, an anarchist who loved to ridicule the system, and a sentimentalist "... who loved the transparency, the simplicity of doing good." Hollington argues that these qualities, despite the European setting, evoke antipodean male "mores and fantasies". 25 Keneally signals the Australian participation in the same moral problems as Europe and offers Schindler as a hero for Australian audiences as much as for those of Europe and America. Schindler is a man defined by 
the moral ambiguity of decent actions in a time of indecency, and this means he speaks to both Australians and Europeans.

A sense of the Australian psyche then provides a useful key with which to unlock the controversial style and form of Schindler's Ark. Irmtraud Petersson, in "'White Ravens' in a world of Violence: German Connections in Thomas Keneally's Fiction", largely concurs with Hollington in reading a peculiar Australianism in the novel, linking it with the conception of a post-colonial Australian identity that is examinable and identifiable by asking what distinguishes Australia from other cultures and through what means of representation or models of identification an Australian identity is reflected in other cultures and societies:

The debate about 'radical/nationalist' vs. 'universalist' positions and their 'post-colonial' variants may have become more refined, but hardly less self-conscious. Cultural independence comprises the readiness to look for similarities as well as differences, for models and anti-models "out there". Perhaps cosmopolitan rather than universalist, Thomas Keneally is one of those novelists who have addressed national issues within an international framework, and contemporary problems in an historical perspective. ${ }^{26}$

Keneally positions his novel within a cosmopolitan internationalism at the same time as he "Australianises" the heroic accident of Oskar Schindler himself. While he does go to some length to establish the historical accuracy of the story of Oskar (to the point where critics have questioned the genre of the novel) he remains fully aware of the limitations placed on absolute truth in the post-modern climate. In the post-modern view of the world in which everything is seen as text, all true accounts are just stories, and the real has no privilege over the fictional. The divide between fact and fiction is seen to dissolve. As Johnstone puts it: 
We have become ... so acutely aware that any event, situation, relationship is open to so many interpretations, that we begin to wonder whether interpretation is all there is, that if you peel away the fictions you will simply find more fictions underneath. History is being revised so rapidly now that we barely have time to catch up with the latest version of the Kennedys or the Khamer Rouge than another, newer, version takes its place. ${ }^{27}$

Possibly those objecting to Keneally's novel winning the Prize did so from the perspective of the literary company he would be joining. However, Keneally is an accomplished professional novelist with a list of popular and critically successful works many of which deal with such perennial literary concerns as war, violence, crisis, individual identity in extreme circumstances, and national identities through particular references, and three of which had previously been shortlisted for the Booker Prize: The Chant of Jimmie Blacksmith (1972), Gossip from the Forest (1975) and The Confederates (1979). Schindler's Ark perhaps accentuates themes which are interfused throughout his oeuvre, highlighting the formal and thematic idiosyncracies that characterise his writing.

Questions about the "right" of the factually based Schindler's Ark to take its place among the Booker Prize winners should be taken seriously, but the blending of fact and fiction is not peculiar to Keneally's novel. Penelope Fitzgerald's Offshore, conceived heavily from autobiographical experience, is based on a lifestyle and a place which Fitzgerald did experience, and to that extent the novel is a fictional rendering of fact. David Storey's rendering of a working-class background in Saville, and Nadine Gordimer's portrayal of a contemporary white Africa in The Conservationist are similar in this respect. How much fact is there in fiction and how much fiction in fact? J.G. Farrell's The Siege of Krishnapur is based on historical event, even down to the particulars of dress; Barry Unsworth's Sacred Hunger is an historical novel only one remove from the historical realism of The Siege; and Golding's Rites of Passage is a 
meticulously researched and historically evoked epistolary "fiction". Similarly the intertextual and multiply-layered narrative of A.S. Byatt's historical detective story Possession lends the work a fictional edge through its complex representation of the layering of what is presented as historical "fact", the uncovering of which blurs with the lives of the protagonists in the novel's contemporary present. What all these examples illustrate is that Keneally's novel brings into focus issues concerning the inter-relation of fiction and fact, in terms of a literary perspective that sees familiar modernist (hierarchical, and essentialist) categories eroded, and replaced by the ambiguities of authenticity, culture, and "self". When fiction and fact are accepted as interchangeable and multiple narratives compete for our attention, the stable and "authentic" notion of self is brought into question in a culture that is characterised by fragmentation and the kaleidoscopic representation of history. In such a highly textual and metaphor-centred society, the notion of absolutes loses meaning, hence the relevance of Schindler's list (as an absolute good) and Schindler's story as ambiguous "fact", or faction.

The issue of whether the novel could be categorised as fiction was in part prompted by conflicting descriptions when it was first published. It first appeared on publisher Simon \& Schuster's lists as "non-fiction novel" and was changed by Ion Trewin at Hodder, who felt this term would be puzzling in Britain, to the category of "fiction" accompanied by an author's note in explanation, and this "compromise" was made before the Booker nominations for that year. Keneally himself fuelled controversy in this seemingly contradictory "author's note" in which he wrote:

To use the texture and devices of a novel to tell a true story is a course which has frequently been followed in modern writing. It is the one I have chosen to follow here; both because the craft of the novelist is the only craft to which I can lay claim, and because the novel's techniques seem suited for a character of such ambiguity and magnitude as Oskar. I have attempted to avoid all fiction, though, since fiction would debase 
the record, and to distinguish between the reality and the myths which are likely to attach themselves to a man of Oskar's stature. ${ }^{28}$

Keneally thus wishes to use the "texture and devices of a novel", but attempts to "avoid all fiction" in conveying the "reality" and not the "myth" that surrounds Oskar's story. However, Keneally's novel, be it fiction or fact cannot help but add to the myth about Oskar and a work which avoids fiction yet employs the texture and devices of a novel is simply fiction with a factual underpinning. Schindler's Ark does consciously eschew a journalistic tone, the author letting Oskar's story tell itself and only intruding self-consciously to allow an authorial omniscience to accentuate some aspect of the storytelling.

However, in the depthless and style-driven world of contemporary post-modernism the factual basis of Keneally's novel actually serves to undermine post-modern surficiality. By telling a story of an author telling a story, it places the author squarely back within the novel, and from this point of view the "fact" of Oskar only goes to reinforce the process. While some may interpret the rise of fact-based fiction as a loss of faith in contemporary literature, actually it signifies the opposite; it is not imagination that the author lacks, but authority. Writing about a factual character lends the narrative an authority which has latterly been absent.

Schindler, "Ned Kelly of Cracow", is a man raised from the obscurity of history by war. He is a man of vices within a theatre of evil-and it is vices which enable him to survive and in so doing secure the lives of the "damned". The womaniser, the apolitical entrepreneur, is ambiguous fact dressed up in fiction. He represents identity in a sea of the walking dead, the people who face the social apocalypse of Hitler's genocide, and his text-his list-means life: real life, salvation, "fact".

The issue of fiction and fact aside, Keneally's novel is riddled with contradiction and ambiguity. This is part of the novel's strength. Schindler is apolitical, amoral; he survives because he is a pragmatist, a man of vice who is able to manipulate the vice in others. His virtue is ambiguous: on the one hand he does shepherd his Jewish workers 
through the war, shipping them to Moravia at his own expense towards the war's end, but on the other it makes good business sense to use them, because they cost less than Polish workers. Thus virtue is always tempered by pragmatism.

Despite the author's avowed intentions in the author's note, myth does permeate the novel: "For the thing about a myth is not whether it is true or not, nor whether it should be true, but that it is somehow truer than truth itself" (249). As the novel points out, the greatness and the "reality" of Schindler's potential was brought out only during the war. After the war, his businesses failed and his life had less of its wartime glamour. His "imperfections"-gambling, anarchistic tendencies, anti-authoritarianism, sentimentality - enabled him to survive well in the greater evil of the war; however, he became swamped by these same qualities when the greater evil was removed. When the war is over, Schindler is given a ring by the Jews he sheltered, on it inscribed a proverb from Talmudic verse: "He who saves a single life, saves the world entire" (51). The myth of Schindler grows up around the absolute good of the list that enabled the workers to come to Moravia, while all around them fellow non-Schindler Jews were shipped to Auschwitz. However, such is the almost biblical intensity of the list that reality is lost with it; all around the margins of the list lies myth: "the problem is that the list I remembered with an intensity which, by its very heat, blurs. The list is an absolute good. The list is life. All round its cramped margins lies the gulf" (312).

While it is written by an Australian author, the novel nevertheless represents a kind of revivalism in the possibilities for good (albeit an ambiguous good) in a "general" Western man who has suffered under the critique of colonial and post-colonial counter-discourse since the 1940s. There are few Western heroes in the age in which the institutions and academies have purportedly turned away from the rhetoric of imperialism and are lending voice, often inflexibly given the nature of the organisations from which they are voiced, to that of the colonial and post-colonial "Other", the oppressed of the colonial-imperial process. At the same time, the theoretical movements of deconstructionism and poststructuralism have brought about the gradual erosion of authority and advanced a textual relativism, which sees the author disappear along with the subject. These tendencies 
have combined to allow the voice from the former margins to gain an ascendancy within English literature which it has hitherto, and particularly during the modernist era, rarely enjoyed. While this may be seen as a positive trend away from the traditional canon (which at the same time acts to confirm the idea of canonicity), in Schindler's Ark Keneally reverses this trend, yoking an Australian sensibility to a very European history, and through the character of Oskar reaffirms the value of the white masculine subject as a figure of good in a time of evil.

In the age of authorial death there are few heroes. Not surprising, then, that Schindler's "true story" of a man of vice and ambiguity made heroic because of the time, a high-living gambler who managed to do a powerful good at a time of greatest racial threat, should appeal to Western audiences because it presents an acceptable hero in the age of the anti-hero or counter-hero: apolitical, amoral, and flawed yet who did positive deeds.

\section{Anthem for Doomed Youth: Pat Barker's The Ghost Road}

Combining fact and fiction, The Ghost Road continues a moral and intellectual conversation between the psychiatrist W. H. R. Rivers and his patients Billy Prior and the poet Wilfred Owen who are read as exemplars, fictional and factual, of the millions damaged by the trauma by the first "Great" war of the twentieth century. Rivers acts as one participant in a conversation that takes place between many of the wounded, including (in Regeneration), the decorated combat officer and acclaimed poet Siegfried Sassoon, connected by their mutual experience of internment at Craiglockhart hospital and contact with Rivers. In this way the "Regeneration" trilogy explores social change and trauma and anticipates shifts in social consciousness, the relationship between social "responsibility" and individual consciousness, pacifism, attitudes to authority, and exposure to and contact with the "Other" and within the self as the result of the abjection or damage of war. It also registers the tumultuous changes in early twentieth century 
Europe and the shift from a Victorian to a modern consciousness that followed from the alienating horrors of war.

Interactions within the empire are explored in The Ghost Road through Rivers's memories of Eddystone Island, Melanesia, where he lived with headhunters, and which he recollects while feverish with Spanish influenza. In this way the novel reflects imperial expansionism. These memories are thematically interwoven and interconnected with his experiences of war: "Rivers extracted his memories of France from him, one by one, like a dentist pulling teeth." 29

The Ghost Road is written from multiple viewpoints, and combines fact, and sometimes imagist description, with the diary entries written in France by the novel's principal fictional protagonist, Billy Prior. The novel opens with Prior and Owen exchanging remarks while undergoing a medical examination which will determine their fate in the latter half of the war. Attention then focuses on Craiglockhart hospital and the interactions of psychiatrist Rivers with his patients. From the outset the hospital is reintroduced through the childlike anamorphic lens of distorted perception with "crude copies" of Tenniel's drawings from Alice in Wonderland decorating one end of Ward Seven. Rivers knew Lewis Carroll and saw the drawings "not as an irrelevance, left over from the days when this had been a children's ward, but as cruelly, savagely appropriate. All those bodily transformations causing all those problems. But they solved them too. Alice in Hysterialand" (24). Rivers reflects on the drawings as haunting representations of the mental and physical trauma suffered by his patients.

Barker's novel, while ostensibly a descriptive and dramatic narrative, is also reflective of psychiatric and semiotic thought, exploring the divide between conscious and unconscious thought processes, and the symbolic function of language. Thus for example, a patient, Dodgson (Lewis Carroll's real name) reflects on snakes after his attention is drawn to a figure in Tenniel's drawings, and Rivers attempts to restore feeling to another patient's, Moffet's, legs after hysterical paralysis, "[a] positive orgy of twitching" (21). These visual and emotive promptings inspire reverie in Dodgson in 
which anthropomorphism blends into zoomorphism, and a representational language is induced between man and nature:

They rounded a bend, Dodgson and the girls leading, and there, right in the centre of the path, was a snake. Zigzag markings, black on yellow, orange eyes, forked tongue flickering out of that wide cynical (anthropomorphic rubbish) mouth. Dodgson went white. He sat down, collapsed rather, on a tree stump and the girls fanned him with their hats, while father caught the snake in a cleft stick and threw it far away, a black $S$ against the sky unravelling as it fell (22).

While this might be innocently interpreted an instance of symbolism blurring into structuralist representation, it is also, less innocently, symptomatic of a psychosis induced by the the state of perpetual tension, fear, and hysteria in the context of trench warfare. The result can be decompensation, ego disintegration, depersonalisation, and occasionally psychotic transfiguration. As McNeil puts it in The Psychoses:

In the normal course of living-attempting to solve problems and defending one's self against the experience of severe anxiety-the individual makes a number of adjustments in his patterns of thinking, feeling and behaving. He compensates for the pressures he is experiencing, and, if the stress intensifies or the defensive manoeuvres he undertakes prove to be insufficient to the task, there is a sudden decompensation in which wild and deviant forms of behaviour appear as the integration of his psychic structure deteriorates and repressed impulses and urges come to consciousness. Ego disintegration under stress is called decompensation .... When the individual undergoing decompensation and psychotic transfiguration begins to sense that he differs from others and is drifting away from close emotional contact 
with them, he may experience a disturbing sense of depersonalization .... Some patients complain of feeling that things have become unreal and that their ability to respond with appropriate emotion is severely diminished. The body and the external world become alien, and the person feels detached from it as though he moves through familiar paces—robotlike-while observing himself from outside his body. ${ }^{30}$

The theme of dislocation in The Ghost Road is apparent not only in mental and physical trauma, warfare, or the representational quality of language as an interstice between man and nature, but also in the ever-present and entrenched concern with the class system. Throughout the "Regeneration" trilogy the "enemy" is not so much that of the opposing side, who generally remain faceless in the novels, but that of the mind itself-the dark side of the unconscious surfacing in the trenches of World War I, or rather primarily in (lack of) thought that put people there, people at war with the idea of war, people at war with the idea of people. Far from levelling class boundaries, with some exceptions war seems to entrench them, with those from the upper and middle classes mainly becoming officers behind the lines and those from the lower classes, canon fodder.

Both Prior and Owen return to the trenches having undergone treatment in Craiglockhart hospital; both in a sense, then, are real test cases, ironically, for determining whether Rivers's therapy is "successful". Yet as Prior leaves Rivers's company, Rivers can't help reflecting on the theme of sacrifice, making a cross-cultural comparison between the killing of illegitimate sons, and a depiction in a stained glass window in one of his father's churches of the biblical scene where Abraham has his knife raised to slay his son and a ram is hiding in the thickets.

Returning to Etaples, the novel diverges into the ironic and somewhat cynical but worldly-wise voice of Prior's diary, in which the humanity of Owen and Sassoon is countered by the almost existential detachment which Rivers observes in Prior. As Prior reflects: "[i]t's the impersonality that forms the biggest part of the sheer fucking nastiness 
of the place. Nobody knows anybody. You marshal men around-they don't know you, don't trust you (why should they?) and you don't invest anything in them" (114). Prior's observations of the quiet time at the front (evening, the time between battles) is of a sense of colourlessness, fear, and "scribbling away" in the dark: "[a]nd not just letters either. Diaries. Poems. At least two would-be poets in this hut alone" (115).

Prior's diary entries are themselves intercut with Rivers's reflections on the time spent on Eddystone Island before the war, a world far apart from "civilisation" and the life of a Cambridge don. Barker allows her protagonist to reflect on the gulf between civilisation and primitivism, the way in which societies construct and maintain an image of themselves, the way in which sanity can be socially determined, the way in which the divide between sanity and insanity is ambiguous. Thus Rivers reflects on the gulf between his Western perceptions and those of the Eddystone Islanders:

He looked up, at the blue, empty sky, and realized that their view of his society was neither more nor less valid than his of theirs. No bearded elderly white man looked down on them, endorsing one set of values and condemning the other. And with that realization, the whole frame of social and moral rules that keeps individuals imprisoned-and sane-collapsed, and for a moment he was in the same position as these drifting, dispossessed people. A condition of absolute free-fall (119-120).

The "absolute free-fall" that Rivers describes and his empathetic judgement that he might for a moment abandon the social and moral "rules" of civilisation that define his sanity and enter the "drifting, dispossessed" condition of the Eddystone Islanders is a judgement made from the position of the "benign" imperialist. Perhaps the Eddystone Islanders would see themselves as neither "drifting, or dispossessed". Again, Heart of Darkness-like, Barker conflates the imagined experience of the "Other" with that of the experience of trench warfare, in which ironically it is the European who is relativised, 
drifting, dispossessed, damaged and abject. Rivers's reflection reveals the imperialist psyche brought up against an image of itself-the tendency, under imperialism, for contact with the "Other" to reinforce and reflect part of the self; for the "Other" to function as a scapegoat for tendencies the European psyche would rather repress. The condition of "absolute free-fall" may well be an accurate description of the Westerner cut free from his or her moral and social base; but this is no reason, Barker seems to suggest, for Rivers to presume it is the mental or social base of the Eddystone Islanders who have their system of customs, conventions, superstitions, social mores.

Barker questions the stability of morality and social convention through this crosscultural comparison between Rivers's reflection on the Eddystone Islanders and the horrors of World War I, between civilisation and its rupture and perversion. Trench warfare becomes analogous of the wounded psyche, paranoia, hysteria, shell-shock of nations caught in a senseless, purposeless, entropy and irrationality. As Prior comments to Owen:

\footnotetext{
'What do I think? I think what you're saying is basically a conspiracy theory and like all conspiracy theories its optimistic. What you're saying is, OK the war isn't being fought for the reasons we're told, but it is being fought for a reason. It's not benefiting the people it's supposed to be benefiting, but it is benefiting somebody. And I don't believe that, you see. I think things are actually much worse than you think because there isn't any kind of rational justification left. It's become a self-perpetuating system. Nobody benefits. Nobody's in control. Nobody knows how to stop (144).
}

Barker fuses the colonial-imperial psyche with Rivers's reflections on Eddystone Island. Rivers's experiences on Eddystone Island metaphorically prefigure his encounters with the Other "within" precipitated by warfare. The spirituality and primitivism of the Eddystone Islanders become a part of Rivers's own psychic makeup, their spirits become 
his-the ghosts of warfare. As Rivers later reflects: "[t]en years later, throwing off hot sheets, Rivers reflected that the questions the ghosts had asked had all been questions the living people wanted answered. What were the white men doing on the island? Were they as harmless as they appeared? Why did they want to know the language of the ghosts? Was it possible the spirits might be offended by their presence?" (211)

Fear based on ignorance thus provided much of the impetus for the perpetuation of the war. For Prior, Owen and Sassoon "the war-returned" the war is as much a journey into the mind as it is into a physical territory. Confusion, destruction, pandemonium, fear, a strange kind of frozen reflection, shell-shock, a science of destruction and reconstruction, amid a general kind of helplessness characterise the mental landscape. As Prior wryly reflects in a letter:

As far as I can make out, Rivers's theory is that the crucial factor in accounting for the vast number of breakdowns this war has produced is not the horrors-war's always produced plenty of those-but the fact that the strain has to be borne in conditions of immobility, passivity and helplessness. Cramped in holes in the ground waiting for the next random shell to put you out. If that is the crucial factor, then the test's invalid - because every exercise we do now is designed to prepare for open, mobile warfare. And that's what's happening-it's all different ... New kind of war. The trouble is my nerves are the same old nerves. I'd be happier with a ton or two of France on top of my head (172).

Prior, who while a reflective character is nevertheless pragmatic and self-disclosing, believes himself to be a casualty. He is a remarkably stable patient. He is cynical but with a kind of goodwill that becomes a double-coded sub-theme of Barker's novel which articulates the bleak no-man's land between the ideal of paradise gained and the mutually assured horror in warfare of paradise lost, the paradox of warring to preserve religious 
beliefs: "He lit a cigarette and thought glossolalia. 'A spiritual gift of no intrinsic significance, unless the man possessing it can interpret what he receives in a way that tends to the edification of the faithful"' (79). As Prior reflects in a letter: "We are Craiglockhart's success stories. Look at us. We don't remember, we don't feel, we don't think -at least not beyond the confines of what's needed to do the job. By any proper civilized standard (but what does that mean now?) we are objects of horror. But our nerves are completely steady. And we are still alive" (200). Thus Barker's imagining of the public and private horrors of warfare and the elision of post-Victorian empire as both entropic and vastly strange to cultures outside Europe indicates the consequences during the early twentieth century of European expansionism and make her novel distinctive among the Booker Prize winners that have post-1950s settings.

\section{Conclusion: European Expansionism}

The Enlightenment movement, by the late twentieth century, has been seen by Marxist post-modernists, feminists, and post-structuralists as the ideological arm of the rationalising and dehumanising logic of the industrial capital's drive towards an efficiency which is its own (ultimately irrational) end. As such, it feeds into the metanarratives of capitalism and patriarchy and has been derided for its projection of an order and meaning where none in fact exists. It is seen as negative by Marxists in so far as it is responsible for the attempt to isolate the individual from the processes in which he or she is situated. The Enlightenment was an event, a series of historical processes, located at certain point in development of European societies. In Thomas Keneally's Schindler's Ark and Pat Barker's The Ghost Road, the Enlightenment sense of progression is halted, and focus is directed at the frustrations of an ethnically diverse and ailing Europe; the colonial impulse of the British Empire is rapidly retrenched in the First World War and the expansionary goals of Nazi Germany under Hitler are checked in the Second World War.

Pat Barker won the Booker Prize in 1995 for the third novel in her "Regeneration" trilogy, The Ghost Road. Set in 1918 during the last year of the first World War, The 
Ghost Road develops themes which she tangentially explored in the earlier novels, Regeneration (1992) and The Eye in the Door (1993). These themes are those of change and entropy in Europe, British class consciousness and its effects, the mental and physical trauma caused by warfare, the psychopathology of individuals and of society when pushed to extremes, and the "state of mind" of post-Victorian Europe.

The energy that went into fighting the wars in Europe fundamentally crippled the British Empire, disrupting the established patterns of trade and drawing heavily on material and human reserves both "at home" and in the colonies. Modernist introspection and "depth" follows from the emotional and psychological horrors of warfare. The redistribution of populations and ethnicities undergone as empire changed and the two world wars established new balances and boundaries of power, both in and outside Europe, irrevocably altered the identities of all those involved. The war efforts helped re-binarise Britain's sense of identity inside Europe, just as the internal sense of the self was fragmented and even sundered by the horrors of war. During the Second World War Hitler's persecution of the Jews revealed a new sense of the European abject and the unequivocal opposition to this forced Britain to confront the spectre of its own racism in the colonies.

Concerning the First World War, The Ghost Road can be interpreted in the context of a British resistance to European expansionism, and the novel highlights the psychological and sociological consequences of cultural collision either under the excentricity of empire or as the result of suffering a world war. Schindler's Ark continues the theme of suffering, alienation and European entropy in the context of the Second World War in Europe.

Criticisms have been made of Schindler's Ark in terms of its stylistic form, the success and literary merit of the novel in which Oskar's story is retold, and the extent to which the figure of Schindler interacts with an Australian national psyche or functions as a character on the stage of post-war international affairs. While the events of the novel and the lives of characters take place in Europe they also have curiously "Australian" resonances. Schindler's Ark harbours a subtle form of appropriation which involves the 
idealised projection of Australian values, themes and discourses onto the character of Schindler. In adopting the story of Oskar Schindler, Keneally generates a sense of Australian participation in the wider ethical issues that the novel discusses-the treatment and condition of the "Other", the atrocity of genocide, and the affirmation of positive antiauthoritarian and capitalist values.

Keneally's novel, like The Ghost Road, points to the complexity of post-imperial Europe. The character of Schindler is multifaceted and complex: a register-like the complex mental worlds of Rivers's patients at Craiglockhart hospital-of the turmoil of twentieth-century Europe, the break-up of the European empires and the fragmented and combinatory identities that emerge from the vast redistribution of peoples and resources that occured in Europe as a consequence of the two world wars. Late-imperial England and Europe saw vast change as ties with the colonies waned under the burden of the war efforts and the colonies themselves went about the difficult business of forging their own identites in a multi-polar world.

\section{Notes}

1Jurgen Habermas "Modernity versus Postmodernity" in A Postmodern Reader, eds. Joseph Natoli and Linda Hutcheon (New York: State University of New York Press, 1993), p. 98.

${ }^{2}$ Derinda Outram, The Enlightenment (Cambridge: Cambridge University Press, 1995), pp. $1-30$.

3John Berger, G. A Novel. (London: Weidenfeld \& Nicolson, 1972), p. 133. All further quotations from this work are taken from this edition and are followed by the relevant page number in parenthesis.

4Joseph H. McMahon, "Marxist Fictions: The Novels of John Berger", Contemporary Literature XXIII, 2 (1982), p. 202. 
5Kiernan Ryan "Socialist Fiction and the Education of Desire: Mervyn Jones, Raymond Williams and John Berger", in The Socialist Novel in Britain, ed. Gustav Klaus (Sussex: The Harvester Press, 1982), p. 182.

6McMahon, "Marxist Fictions", p. 216.

${ }^{7}$ Ryan, "Socialist Fiction and the Education of Desire", p. 182.

${ }^{8}$ A.R. Bras, "A Sense of the Future: The Work of John Berger", Critique 25:3 (1984), p. 132 .

${ }^{9}$ Bras, "A Sense of the Future", p. 134.

${ }^{10}$ Bras, "A Sense of the Future", p. 134.

11McMahon, "Marxist Fictions", p. 218.

${ }^{12}$ Raymond Mazurek, "Totalization and Contemporary Realism: John Berger's Recent Fiction", Critique 25:3 (1984), p.138.

${ }^{13}$ McMahon, "Marxist Fictions", p. 224.

14J.H. Stape, "Fiction in the Wild, Modern Manner": Metanarrative Gesture in William Golding's To the End of the Earth Trilogy", Twentieth Century Literature 38:2 (1992) p. 230 .

${ }^{15}$ William Golding, Rites of Passage (London: Faber and Faber, 1981), p. 125.

${ }^{16}$ Arnold Van Gennep, The Rites of Passage, trans. Monika B. Vizedom and Gabrielle L. Caffee (Chicago: University of Chicago Press, 1972)

${ }^{17}$ James Gregor and Mark Kinkead-Weekes, "The Later Golding", Twentieth Century Literature 28:2 (1982), p. 113.

${ }^{18}$ William Nelson, "The Grotesque in Darkness Visible and Rites of Passage", Twentieth Century Literature 28:2 (1982), p. 193.

${ }^{19}$ Greg Dening, Mr Bligh's Bad Language: Passion, Power, and Theatre on the Bounty (Cambridge, England; New York: Cambridge University Press, 1992), p. 19

${ }^{20}$ Barry Unsworth, Sacred Hunger (London: Penguin, 1992), p. 19. All further quotations from this work are taken from this edition and are followed by the relevant page number in parenthesis. 
21 Thomas Docherty, "Postmodern Characterization: The Ethics of Alterity", in Postmodernism and Contemporary Fiction, ed. Edmund J. Smyth (London: Batsford, 1991), p.171.

${ }^{22}$ Docherty, "Postmodern Characterization", p. 171.

${ }^{23}$ Docherty, "Postmodern Characterization", pp. 171-172.

${ }^{24}$ Dening, Mr Bligh's Bad Language, p.322.

${ }^{25}$ Michael Hollington, "The Ned Kelly of Cracow", Meanjïn, 42:1 (1983), pp. 42-43.

26Irmtraud Petersson, "'White Ravens' in a World of Violence: German Connections in Thomas Keneally's Fiction", Australian Literary Studies, 14:2 (1989), p. 160.

${ }^{27}$ Richard Johnstone, "The Rise of Faction", Quadrant 210, 29:4 (1985), p. 76.

${ }^{28}$ Thomas Keneally, Schindler's Ark (London: Coronet, 1983), pp. 9-10. All further quotations from this work are taken from this edition and are followed by the relevant page number in parenthesis.

${ }^{29}$ Pat Barker, The Ghost Road (London: Viking, 1995), p. 33. All further quotations from this work are taken from this edition and are followed by the relevant page number in parenthesis.

${ }^{30}$ Elton B. McNeil, The Psychoses (Englewood Cliffs, New Jersey: Prentice-Hall, 1970), pp. 37-39. 


\section{Chapter Three \\ Post-colonial Pessimisms}

1. Introduction: Post-colonial Pessimisms

2. Migrant Displacements: V.S. Naipaul's In A Free State, 1971

3. Colonial Dislocations: Nadine Gordimer's The Conservationist, 1974

4. Primordial State: J.M. Coetzee's Life and Times of Michael K, 1983

5. Fantasy and Biculturalism: Keri Hulme's the bone people, 1985

6. Colonial Folly: Peter Carey's Oscar and Lucinda, 1988

7. Conclusion: Visions of Disharmony

\section{Introduction: Post-colonial Pessimisms}

Following the spread of empire, the intermingling of cultures of the coloniser and the colonised, and the assertion of separate national identity either under empire or alongside it, a series of novels arises which articulate the problems and stasis of the post-colonial nation: its racial disharmonies, its economic dependencies, its welfare and cultural problems.

In A Free State, The Conservationist, Life and Times of Michael K, the bone people, and Oscar and Lucinda can be characterised among the Booker Prize winners by their sense of cultural collision, unease, and disappointment. They are novels which reflect the futility and pessimism of post-colonial cultures - the recourse to an identity which is fractured by the dominant presence of the settler-invader and less than whole, dislocated; or they are novels which have protagonists who are simply misfits and unable to come to terms with life in the colonies, as in Peter Carey's Oscar and Lucinda.

Naipaul, Gordimer, Coetzee, Hulme, and Carey are the authors of Booker Prize winning novels which straddle two or more cultures, often with a sense of "belonging" 
uneasily to both, and with ambivalent views of cultural interaction and a notion of identity which lacks a unitary impulse or organising principle. For these writers the translation between cultures is a major preoccupation. It is frequently through a Western "lens" that they write of the experience of indigenous cultures in a state of post-colonial flux. Naipaul's, Gordimer's, Coetzee's, Hulme's, and Carey's novels, are either contrapuntally engaged with the indigenous "self" or they directly confront the ideas of nativist subjectivities as counter-discourse and opposition to the dominant culture, or they offer the deconstructed subject as a form of resistance to Western society. They are frequently dystopic - offering not just visions of a sense of "Eden" abandoned but of the colonial dream perverted. Carey's vision in Oscar and Lucinda is of an Australia doubly disappointed, with "Eden" rediscovered only to be corrupted anew, as racial differences and value systems clash and fail to cohere into an integrated experience of belonging and common sense of nationhood.

The post-colonial cultures that these writers represent-South Africa, New Zealand and Australia-exhibit nationalisms which are constantly under interrogation with complex patterns of historical occupation and succession, complex interacial balances, and various resistances and acceptances of the belief in possibility for harmonious national development.

\section{Migrant Displacements: V.S. Naipaul's In A Free State}

Indo-Caribbean Vidiadhar Surajprasad (V.S.) Naipaul won the Booker Prize in 1971 for his five-part fictional work, In A Free State. Naipaul belongs to a family of writers. His father was a writer and his brother also. V.S. Naipaul is a prolific writer. He has written over twenty fictional, autobiographical, and travel books and many reviews and critical essays. Naipaul has been knighted for his services to literature, yet remains a figure of literary controversy. Novels such as In A Free State, Guerillas (1975), The Mimic Men (1967), A House for Mr Biswas (1961), A Bend in the River (1979) and The Enigma of Arrival (1987), which concern themselves with themes of identity and alienation in 
colonial and post-colonial conditions, distinguish Naipaul as a novelist of insight into the darker aspects of interaction between the agents and victims of empire. Naipaul's writing is constrained by its rigidity, an unwillingness to consider what is seen as the positive aspects of cultures in conditions of flux and change, and also by the unerring way in which he depicts the bathos of the post-colonial encounter without a counterbalancing positivity or affection. He is an unerring critic of the Third World.

Naipaul remains controversial for two major reasons: firstly he has come under attack for his criticism of the country of his birth and ready adoption of "British" values and First-World ideologies; and secondly, for his portrayal of women and blacks. While his writing style is very often praised, the ideology it displays has been the occasion for criticism.

The first of these criticisms, levelled in such articles as Adewale Maja-Pearce's "The Naipauls on Africa: An African View", concerns the supposedly "racist" thought of the Naipaul brothers. Maja-Pearce's suggests that V.S. Naipaul's In A Free State is derogatory of black Africa. Maja-Pearce's argument is summed up in the following passage:

no-one is denying that Africa is in a state of tremendous upheaval; noone is denying that many of the perversions of modern Africa are absurd. Modern Africa is in a state of flux, in the same way and to the same extent that any society or culture which has been smashed repeatedly is in a state of flux. Nor is anyone denying that the Idi Amins and the Bokassas are laughable: all tyrants, whoever they are ... can and should be laughed at. But our laughter is tempered by the knowledge of the suffering they cause, suffering which affects real people who feel real pain. The laughter of the Naipaul brothers isn't tempered by this knowledge because, to them, Africans can't be taken seriously: in an insidious way they don't exist for them as real people. This is what offends. And the key to their attitude lies in their worship 
of the West and the Western tradition, a tradition they have swallowed wholesale and which they measure everything else by. Ironically, as West Indians, they are themselves products of a society struggling to find itself after the bloody legacy of defeat and enslavement at the hands of the very tradition they extol. ${ }^{1}$

However, Maja-Pearce's view is contestable. Naipaul is a critic not only of his original culture but also of this culture as it interacts with his adopted culture, and it is this interaction that he takes seriously. However, the cultural interaction he describes is frequently static and fatalistically irreversible. This, then, is the major focus of Naipaul's writing: a portrayal of the wounded colonised of Africa and the Carribean through the adopted ideological gaze of the coloniser, with a sense of comfortlessness for the displaced and compromised of the colonial-imperial relationship. Naipaul's novels invoke the tradition of Joseph Conrad in their inversions of civilised entreaty. This polarity of First and Third World perspectives in content and narratological sympathy informs much of Naipaul's work. Maja-Pearce goes on to accuse the Naipaul brothers of a "slavish worship of an alien tradition which they have adopted wholesale and which they use to measure everything that falls outside it", which she regards as "ignoble" and "shameful" in so far as it is the tradition which is responsible for the "predicament of the people of whom they are so contemptuously dismissive." 2

While Naipaul generally adopts the values of Western civilisation, he does not completely divorce himself from the culture of the colonised; it is present as a signpost of backwardness and failure. Naipaul's work, while never sentimental, is rarely that simple. Instead, In A Free State advances a kind of existentialism which, as Bruce King points out in V.S. Naipaul, juxtaposes in places a sense of one extreme of Western individualism with Indian "fatalism and passivity." However, while King asserts that the "two opposing views are blended together into a distinctive pessimism, an existential despair", Naipaul's writing is not entirely encompassed by such a pessimistic regard. ${ }^{3}$ $\mathrm{He}$ is ostensibly a realist who points to a darkness in the human condition. His 
pessimism is derived from the unsentimental and uncompromising way in which he portrays his protagonists' recognition of the extremity of acceptable Western notions of "humanity" in colonial and post-colonial conditions. Thus, in portraying the culture of his country of birth in conditions of compromise he presents an image to the West of the more brutal aspects of empire's end and of the bleaker conditions of post-colonial regeneration. As Dennis Walder puts it: "this is a book about empires and about what happens as one empire comes to an end and another begins. It is also about what happens to individuals caught up in these large movements of history, their struggles (generally futile) to be free." 4 Naipaul explores the tension between the controlling influences of society and a freedom that suggests a kind of anarchy when social rules and regulations break down, a tension he identifies as between civilisation and savagery and one that is potentially endemic to all societies which involve the interaction of two or more cultures.

If Naipaul presents an image to the West of Western superiority he does not always show this superiority in a entirely favourable light. Conditions for the "colonised" English immigrant are no better than those from the colonial home, as his story "One Among Many" in In A Free State, suggests. Naipaul's existential metaphysics are intimately related to his poetical and historical interpretations. He is a writer of extremes and conveys a sense of banality that underscores both Western individualism and Eastern universalism, and this banality represents a kind of negative humanism.

Naipaul's controversial position as a colonial and post-colonial writer stems from his acceptance of the dominant imperial culture, and his unwillingness to move beyond the conception of a superior Western society to one that embraces the politics of pluralism, which displace the paradigm of centre and margin. His portrayal of the literal and geographical reading of colonial and post-colonial settings is characterised by a bleakness in which each moves past the other in the mirror worlds of the banal and the base. As Selwyn Cudjoe points out, Naipaul's apocalypticism with regard to the Third World is without repentance or moral uplift: 
As we observe the apocalyptic gloom and absolute hysteria in Naipaul's later work, it becomes clear that he is unable to move beyond the manipulation of imposed binary ethical oppositions to a dialectical interpretation of postcolonial reality. Moreover, his inability to change the conceptual framework on which his analysis is based leads to a kind of banality: a prose that evinces a brilliant sense of craftsmanship even though the content of the social reality he examines is narrowly circumscribed. $^{5}$

Naipaul's apocalypticism does in some instances descend into a banality which consolidates and entrenches the conception of colonialism as a binary configuration between a superior and dominant coloniser and an inferior and backward colonised. It is not surprising, therefore, that the West should regard him with favour in his construction of, at best, an ambivalent image of the Third World. But therein lies the irony of Naipaul's writing: that positive image of Western cultural dominance is imposed as an underlying assumption in Naipaul's novels which works against the development of narrative by undermining the fluency of its socio-historical setting. As Cudjoe points out, characters in In A Free State are drawn as "individual subjects rather than transindividualized historical subjects of a new society". 6 Cudjoe's suggestion is that Naipaul imagines pre-conceived and rigid characters in a post-colonial setting, rather than letting the setting itself determine the nature of the characters.

The stories and novella that comprise In A Free State span three continents, but the society they present is that of a "limbo" world, not dissimilar to J.M. Coetzee's South Africa in Life and Times of Michael K, characterised by emptiness, hopelessness, fantasy, and brutality. While the ideological assumptions of the coloniser are upheld, the negative aspects of imperialism and late-capitalist bourgeois life are presented with a bleakness equal to the depiction of the spiritual bankruptcy of the colonised.

Naipaul's vision of post-colonial reality is that of a jumble of individuals and nations in a permanent state state of flux, capturing the stasis of the newly post-colonial culture, a 
position from which he rarely moves. He views the exploitation and abuse of colonial peoples as a matter of allowing themselves to be abused, and this flaw is a consequence of the limitations of their culture. Poverty leads to corruption, and greed to exploitation. He is both cynical and disparaging of the willingness with which the oppressed seek to identify themselves with the oppressor and also the reverse, in the bogus bankruptcy and sentimental hoax of black movements, which while enjoying the status of media chic in the United States, in Trinidad remain irrelevant and unsanctified by media promotion.

Naipaul's personal sense of liberation through the Western aesthetic of individual achievement leads him to undermine both his own society and the programme of postindependence rehabilitation emergent in the wake of the dissolution of empire. At the same time he is valorised by the West. He views cultures and language as acting on people rather than people acting on language: a deterministic world. As Cudjoe puts it:

He can see only how language 'uses' the colonized person rather than how the newly freed subjects use and expand language as they live their new reality and realize themselves through language. It is clear that because Naipaul understood only the first level at which language operates he was unable to appreciate the new subject's struggle to appropriate language and to shape it to his contemporary needs. ${ }^{7}$

However, in In A Free State, the language of the coloniser remains an oppressive experience to the colonised. It is a static force against which they measure their own marginalised sense of assimilation; it becomes a constant reminder of cultural alienation. To the coloniser, language is a point of closure, a hegemonic device by which nationality is maintained and expressed, while territory is demarcated and controlled. Language acts as a barrier, a device by which cultures and races articulate their division and separateness as opposed to a medium by which they negotiate a mutual sense of identity. 
Naipaul's own sense of cultural unease is articulated through novels which express the extremes of alienation as cultures are changed in the wake of a progressive imperialism, and traditional ways of life and values undermined and often replaced. In A Free State presents varied experiences of hostile environments in which the notion of authentic identity is perpetually deferred; areas of colonial influence in which, as Cudjoe again puts it, the "discovery of a social role does not coincide . . . with a discovery of the self, rather it implies the adoption and maintenance of a mask." 8

In A Free State articulates Naipaul's sense of placelessness in colonial and postcolonial worlds through two short stories "One of Many" and "Tell Me Who to Kill" and a novella, "In a Free State", from which the collection derives its title. These are flanked by a prologue and epilogue which take the autobiographical form of Naipaul's travel writing. The "novel" thus entertains personal observations with fictional worlds in a blurring of genres which is characteristic of much of Naipaul's fiction. His concept of a liberated post-colonial subject announced in this literary form is a characteristically bleak one, in which his subjects largely exist outside of, or uncomfortably on the periphery of, the societies in which they are set. As Helen Tiffin observes:

. . the emphasis placed by the colonial on the world outside introduces an element of fantasy which Naipaul feels is an inescapable part of the colonial inheritance. This historically engendered longing for worlds elsewhere encourages self-denigration and automatically ensures that the colonial will never be "at home" in either of his/her worlds, perpetually condemned to a loneliness that, while it may be metaphysical in extension, is primarily historical and social. A colonial or post-colonial life or society is thus, by definition, the product of two intrinsically interwoven worlds whose tensions find expression in feelings of alienation, frustration, fantasy and violence. ${ }^{9}$ 
The prologue, "The Tramp at Piraeus", describes a two-day crossing from Piraeus to Alexandria in an overcrowded Greek steamer where "there wasn't enough room for everybody."10 From the outset the familiar Naipaulian themes of cruelty, materialism, isolation, restlessness, and crowding are introduced, pitting the multinational peoples of modernity together on a dirty vessel in which "Greek civility was something we had left on shore ..." (9) The ship becomes a metaphor for post-colonial fragmentation and a cynical entrapment of liberated Western nationalism.

Naipaul's prologue is a demonstation of international lobbying and nihilism. A political play is enacted on board the theatre of the ship. Naipaul's tale is a dispassionate portrayal of an international gathering of overcrowded nationalisms in which identities are forged and re-forged in terms of political games in which the weak are further displaced and in which the strong are merely exercising their strength. From it the author intimates the themes of placelessness, inauthenticity, brutality, and the paradoxes of freedom which follow in the subsequent stories and novella. The British tramp is a brief parody of the faded grandeur of empire: he looks well dressed from a distance but close up he is dishevelled, mechanistic in his speech, and seeks anonymity among the world's "refugees".

A play on the motto of the United States of America "E pluribus unum", "One Out of Many" is a short story that concerns Santosh, a Bombay domestic servant who, used to the security of anonymity in the crowd of the Bombay street, is transported with his "important" employer to Washington where he is "surrounded" by the ethos of Western individualism. Santosh's sense of displacement is established early on as he is both violently ill and mistreated on his flight from Bombay to Washington. The flight is a "nightmare", he is sick on the champagne he mistakes for soda water, feels persecuted by the flight staff, and arriving in Washington where his employer excuses him as "only a domestic" (30), he feels like a prisoner below the "imitation sky" of this employer's apartment (31).

As the story develops, Santosh is forced to confront the changing perspectives of identity that the two cultures afford. He refers to himself, his friends, and his employer 
in the first person plural, which emphasises his lack of personal identity and his lack of the desire for individuality in himself or in others. Naipaul thus comments on what he feels are the ills of Hinduism, which ascribes people to caste a system with the rigidity of the British class system and encourages a conception of self-limitation in a world that is increasingly premissed on a sense of identity that collapses large issues into the local: "Once my employer had been to me only a presence. I used to tell him then that beside him I was as dirt. It was only a way of talking, one of the courtesies of our language, but it had something of the truth. I meant that ... I experienced the world through him, that I was content to be a small part of his presence .. . Now I found that, without wishing it, I was ceasing to see myself as part of my employer's presence, and beginning at the same time to see him as an outsider might see him. ..." (40-41) Naipaul's "Santosh" is thus a victim. The security of anonymity does not apply in the streets of Washington as it does in Bombay. The subvenience imposed by an Indian caste system is threatened and the material disparity between the two cultures promulgates a sense of imprisonment in Santosh.

The second story of In A Free State carries over Naipaul's themes of displacement, nihilism, loss, and hopelessness in the colonial and post-colonial condition that he establishes in "One Out of Many". His second darkly ironic "free state" is that of West Indian Britain.

For Naipaul, the colonial culture is mimetic, an inferior copy of the metropolitan First World society, and the former "slave" is reduced to the position of copying or "mimicking" his former master. Naipaul has explored this theme more comprehensively in his earlier novel, The Mimic Men, and it is here continued in abbreviated form. "Tell Me Who to Kill" expresses the colonial condition of Santosh in "One Out of Many" but increases the sense of waste and frustration and the concomitant anger engendered by these debilitating emotions and circumstances. The second story also injects a sense of the paranoid into the allegory of colonial entrapment. The extremity of views expressed in The Mimic Men is again born in the unremitting failure of his protagonists either to lead authentic or satisfactory lives in their adopted Britain or to transcend their status as 
mimic men, despite the fact that Frank in the second story accepts his fate with less helplessness than does Santosh in "One Out of Many".

It is easy to see why Naipaul should polarise opinion in the colonial debate so forcefully with his reinforcement of the imperialistic view which is arguably changed in the transition from colonial to post-colonial worlds. This is perhaps ultimately where his reading falters. Naipaul underestimates the elusiveness of the imperialist view. This is not to deny the sometimes appalling conditions which the colonised undergo or underwent but to suggest that the fictional worlds he portrays contain an implicit and static view of imperialism that is increasingly eroded outside Naipaul's fictional world.

"Tell Me Who to Kill" concerns the interaction of West Indians and British, the origins of a multicultural Britain and the displacement of a colonial West Indies. The basic premiss is that the indigenous seek freedom outside the colonies, but find themselves in more constricting worlds as strangers in often hostile adopted environments which they cannot understand. "Tell Me Who to Kill" evokes the shadow world of 1940s and 1950s movies, and the existentialism of "One Out of Many" is replaced by a sense of a higher control ordering the lives of its protagonists.

In the major section of "In A Free State", the novella from which the book takes its title, the familiar themes and motifs of colonial dislocation are continued. Smell is an important linking device between the separate strands of the novel, as is the language of fashion. The black Africans in "In A Free State" are depicted as emitting the same sense of bad smell as the tramp in the epilogue, Santosh in "One Out of Many" and the narrator of "Tell Me Who to Kill". This linking device has been subject to criticism by MajaPearce for its racist implications, while clothes are evoked to suggest either inappropriateness, dislocation, inauthenticity, or assimilation. ${ }^{11}$

In "In A Free State" positions are reversed; the colonial white experiences a sense of dislocation and lack of identity in the post-colonial Africa which he or she has "created". "In A Free State" is the story of a journey through Africa which explores the darkness of colonialism. The novella is written in a remorselessly impersonal third person voice which stands in contrast to the first-person informality of the other sections of the novel, 
foreclosing narrative intimacy with the reader. The central protagonists, Bobby and Linda, are thrown together in a car journey across Africa. They too are victims of the post-colonial nationhood in so far as the withdrawal of empire has thrown them into an Africa of imperial creation with which they cannot fully identify. Like the tramp of the prologue they are never at rest, wandering listlessly through a former colony in which they do not belong. For them home is an England that remains unfulfilling. The story chronicles Linda and Bobby's journey against a back-drop of a colonial culture grafted onto an African culture that makes the suggestion of primitive forces beneath: a nation torn with civil unrest, racial tension, sexual tension, and latent violence. Bobby and Linda, whose relationship unfolds along the journey, fail to see that they do not understand the precariousness of their adopted culture. The illusion of this understanding, the disparity between one culture and the other, the friction with which one culture resists the other, or even a reading of the "Other", become major themes of the story.

"In A Free State" closes with an autobiographical epilogue "The Circus at Luxor" in which an international Egypt is described with the familiar sense of exotic cruelty and national fragmentation. At the climax, where peasant children scrabbling in the sand for food thrown by tourists are whipped for the sport of it, the circus of imperialism is shown to scar the banks of the Nile at Luxor, one act of imperialism overlaid on another. The detached narrator reflects on the possibility of an unmarked vision of the beauty of the Nile, untainted by the cruelty of subordination; he can see nothing as "complete", all is redolent of the amorphous cruelty in colonialism, the mark of the former Roman Empire now reduced to a "postcard" and a sense of injustice: "Perhaps that vision of the land, in which the Nile was only water, a blue-green chevron, had always been a fabrication, a cause for yearning, something for the tomb" (255-256).

In A Free State is characteristic of Naipaul's oeuvre. Its fragmentary composition is both a stylistic and thematic feature. In a fragmented post-colonial world, each of his "free states" ironically offers no senses of freedom to either colonised or coloniser. 


\section{Colonial Dislocations: Nadine Gordimer's The Conservationist}

Much of the tension that pervades Nadine Gordimer's The Conservationist derives from the conflicting pressures of her belief that a writer should value creative freedom more than radical orthodoxy and her equally committed view that apartheid is wrong. If Berger's protagonist $G$ pursues liberty through sexual emancipation in the socially preclusive societies of European empire at the turn of the 19th century, then Nadine Gordimer's Mehring in The Conservationist enacts a story of personal recalcitrance, "white" rootlessness, and solipsism. Like Berger's G, Gordimer's protagonist seeks liberation through sexual activity; however, unlike G, who seeks the liberation of his partners as much as himself, Mehring is an exploiter. Both novels deal with figures who retreat from historical recognition at moments of empire's most visible expression: revolutionary Europe and post-colonial South Africa. Both novels show how history permeates private acts even though the connection is repressed or denied.

Mehring is a womaniser, a rich white South African, a divorced batchelor and an industrialist land-owner who, rather than seeking freedom from South African apartheid, seeks to absolve his sense of alienation and dislocation in an identification with the land that his ancestors have colonised and which he would like to "feel", and not just call, his own. However, the fact that Mehring cannot situate himself in history and cannot reconcile the public and the private spheres in his life with anything other than the immediate environment, which he attempts to control, ultimately precludes his ability to achieve the kind of identification and belonging that he seeks. As Robert Boyers puts it:

What is fundamental in The Conservationist is the process by means of which Mehring continually persuades himself that the private sphere he occupies is his to shape and to dominate. It is a novel of consciousness, not a novel of ideas. It engages necessity not primarily as an effect of circumstance, but as a function of its protagonist's relentless self-deception. The novel knows ever so much more than Mehring knows, but its knowledge is kept implicit 
in deference to its fundamental object, which is the examination of a false consciousness that is endemic in a situation like Mehring's. ${ }^{12}$

Gordimer's novel, like Andre Brink's Rumours of Rain, shortlisted for the Booker Prize in 1978, attempts to reconcile themes of African regeneration with those of a selfquestioning "white" supremacy; to reconcile an understanding of black African and white African consciousness with the dislocation of modernity within which they play unequal roles. The fundamental questions of the novel are shown to be: who shall inherit South Africa, and how shall it be conserved?

Gordimer's highly visual novel begins as Mehring drives onto his farm in his black Mercedes. The "prismatic flash" of the emblem on the car bonnet lines up on a blackchild like the sights of a gun. This is juxtaposed with the image of eggs being gathered by young blacks which Mehring feels are being taken away from him. White South African materialism is thus juxtaposed in an image of tension with the silhouette of black African poverty, fragility and oppression. Mehring's solipsism is intimated throughout the novel, both in his calculated selfishness and his attitudes towards sex. He confides to a girlfriend that there is a "special pleasure" in sexual relations with a woman for whom you've paid: "[t]here will be absolutely no unfulfilled emotional obligations on either side, hanging on afterwards" (77-78). As Judie Newman puts it: "[s]exual fantasy as a surrogate for colonial lusts is extended in ontological terms. As a white South African male, Mehring can have relations with women only as a form of slumming-even without crossing race or class lines."13 Mehring's colonising attitude to both women and land precludes any sense of meaningful connection with either.

In The Conservationist there is a conflict between two conceptualisations of landscape that have a bearing on the white South African consciousness. The first is an elision of landscape with indigenous people as a site to conquer so that white identity is defined as separate from it. Secondly, there is the desire for this landscape to act as a domain for the expression of white identity through the pastoral Arcadian tradition of spiritual and emotional rejuvenation-in harmony with nature as opposed to the sprawling 
urbanization and moral decay of the city. However, these two conceptions are antithetical and therein lies Mehring's dislocation.

South African racism is portrayed unerringly in The Conservationist. Gordimer, through irony, cynicism, and a kind of internationalist gaze punctuated by local knowledge, argues against the system that privileges white over black. The only "egalitarianism" in the novel is in the writing in English, Afrikaans, and Zulu, of the sign forbidding thoroughfare. Gordimer's protagonist, like others in his society, is a modernist living in a post-colonial and increasingly post-modern world. Mehring is a man who has reached the limits of what his society has told him he must be, and looking over the edge of his "empire" we speculate with Gordimer whether he still has the capacity to see it anew and reinvent himself (both in terms of society and landscape) in a form that is reconcilable with his exploitative nature. Mehring's self-conscious unease with his position and concept of self is made overt. There is a sense of his redundancy expressed in his contempt of those who seek to replace him: "In me you see expressed the guilty yearning for the artifacts of the culture we've destroyed. The same thing as young Americans wearing fringed jackets and head-bands" (157). The guilty yearning for destroyed artifacts is tempered by Mehring's pragmatism and suggestion that exchange works two ways, even if it be to the advantage of the white.

The Conservationist is, thus, a novel with a distinct political message. Mehring is alienated from both white society (by choice) and black society by apartheid and social conditioning. Gordimer's participation in this polarised society necessarily modifies her position within a counter-discourse to it. She can write against it but in order to do so she must first immerse herself within it. This is a position that inevitably involves compromise and a blurring of political and aesthetic concerns. A somewhat heavyhanded didacticism is buried within Gordimer's notion of the function of the novelist. Unlike Mehring, she is ideologically opposed to oppression, but like him she is materially complicit. Sex brings Mehring no closer to the identification he seeks than does money. Interracial contact is brief, and conforms to familiar patterns, which Mehring will not disrupt in a kind of racial recalcitrance in his search for a sense of 
belonging. As Irene Gorak puts it: "Most damagingly, for a post-colonial writer, she inherits a radical aesthetic tradition yoked to a quiescent political one. She believes that the writer has a duty to promote revolutionary change, a duty to be fulfilled, however, on the writer's own imaginative terms." 14 However this elision of aesthetic and political considerations may not be as clear cut as Gorak itimates.

Gordimer's narratological sympathy is thus confined to the twin conflicts of Mehring's "disintegration"-with the confirmation of that disintegration by what Gorak calls her "libertine pastoral values". 15 Gorak points out that due to industrial expansion and city development in South Africa during the 1960s and 1970s, the political rhetoric at the time was in natural terms with metaphors of space, air, and wind, with a return to metaphors of freedom and nature for the building of a progressive white society. As white people left the country for the city, blacks were forced to move, and city development increased in proportion to environmental destruction as primary industries such as mining, quarrying and manufacturing expanded.

However, when Mehring's farm is overrun by flood waters, the indigenous are isolated (a body is washed out of its shallow grave) and "re-discover" traditional African beliefs and the ability to run the farm themselves. For them it is as if the waters wash away the dirt of colonialism. Perhaps Gordimer's metaphor here, as Gorak suggests, shows a gesture of sympathy with the Black Consciousness movement. However, Gordimer does not give the Black movement a voice in The Conservationist; her aim, rather, is to expose the hypocrisy, crisis of identity, and modernist alienation of the colonisers among the polarised apartheid society of their own creation, and to suggest the possibility of an older society to which they have little access (largely through continued ignorance). As Gorak puts it: "Mehring's rationalizations barely disguise the degradation of the farm in a society whose industrial development entails a systematic deformation of expropriated land. Mehring's farm accrues in commodity value as it is emptied of human content. Gordimer neatly shows Mehring exporting to the countryside the same casually exploitative relationships he enjoys with his urban sexual partners." 16 The myth common to many colonised societies, that the land was empty of people when the 
colonisers "discovered it", is undermined by Gordimer as she re-introduces black workers and black poverty at the heart of a novel that updates Olive Schreiner's The Story of an African Farm (1883). However, Mehring's conservation is shown to be false: his political consciousness is belied by the shallow grave of the black "gangster" who is dumped on his land. The black workers of his farm represent the experience of reality in the society of polarised extremes.

The conservation of Africa is signified by the parallel themes of white rhetoric and apartheid and the reality of black acceptance; the possibilities of regeneration for both races are hinted at by the pastoral element of the novel. Mehring's positivism will bring about his self-destruction, albeit prolonged by his attempt to conserve the land; the solipsism of white South Africa will be undermined by the reality of black life; and the subtext of the Amazulu religiosity will interrupt the narrative of white South Africa. Gordimer has said in an interview that the conclusion of her novel, where the body that has been buried returns, refers to Mayibuye, the black political slogan that means "Come back Africa." 17

\section{Primordial State: J.M. Coetzee's Life and Times of Michael K}

After enduring numerous hardships in a civil-war-torn South Africa of the near future, Michael K, in J.M. Coetzee's 1983 Booker Prize winning Life and Times of Michael K, imagines at the novel's conclusion a scenario for retrieving water from a well with a bent spoon on a long string: "he would lower it down the shaft deep into the earth, and when he brought it up there would be water in the bowl of the spoon; and in that way, he would say, one can live." 18 Coetzee's novel is concerned with the search for dignity. Michael's story becomes Coetzee's moral parable of an apolitical figure in a political state. Michael's apolitical consciousness reflects an examination of the possibilities of freeing the novel from the available politics of South African discourse. That Michael merely imagines a way of "being" at the novel's conclusion, a way of being that is not possible for him in his present circumstances (those of the South African state of which 
he is only dimly aware), while not necessarily intimating a failure, defers the argument in perpetuity. In Michael $K$, Coetzee portrays a figure who attempts to remain outside political narratives. As Benita Parry puts it:

Detached from the dominant modes of South African writing, obliquely situated to the prevailing intellectual formations of his native land, whether white nationalism, liberally socialist-liberationism or black consciousness, and little touched by the autochthonous, transplanted and recombinant cultures of South Africa's African, Asian and Coloured populations, Coetzee negotiates 'South Africa' as a referent in his fictions through defamiliarizing strategies which efface its spatial and temporal specificity, denying it the identity of a social space and rejecting it as a site of cultural meanings. . . It is [these] connections between landscape and the legitimising narrative of the white nation which the novels sever by ostentatiously failing to register any signs of splendour in the very scenery that has inspired rhapsody. ${ }^{19}$

Like Nadine Gordimer's The Conservationist, Life and Times of Michael $K$ is loosely structured around the African farm novel. But where Gordimer largely updates the anticolonial discourse of Olive Schreiner's The Story of an African Farm, Coetzee's Michael $\mathrm{K}$ treads the first few steps along the trail to the construction of a white African consciousness thus far prohibited in South African society by the roles of coloniser and colonised and, in the latter half of the twentieth century, the artificial social engineering of apartheid. As Derek Wright puts it:

Coetzee seems concerned in this novel to found a new myth of the land: the myth of earth minus man, or at least of Western Technological Man (white), as distinct from Vegetarian, Macrobiotic Man (here, 
black), who eats only what nature supplies and is not damaged by. And since Michael $\mathrm{K}$ is, in fact, less a man than a spirit of ecological endurance, a Gaian ideograph, it remains to ask wherein lies his relevance, whether to the contemporary political situation of South Africa or to the ecological one of the African continent at large. The African earth is here opposed not to industrial overdevelopment but to colonialism and war specific to the South African Context. ${ }^{20}$

Like the hybrid, polyglot India of Rushdie, the South Africa of Coetzee is one of many languages, races, and tribes. The nation of South Africa lacks a coherence that the dominant white minority of Afrikaan's or Boer has prevented through apartheid, censorial legislation, economic and social exploitation, and the privileging of the white race over the black. As Coetzee has put it, his writing reflects "concerns of people that are no longer European, not yet African." 21 Within the South African racist state, the fiction of Coetzee, who is of Afrikaner descent, is that of a colonialist, but one who is disparaging of the negative social consequences of colonialism in South Africa. As Stephen Watson puts it: "The one fact most important for an understanding of the apparent anomalies in his work is that he is not only a colonizer who is an intellectual, but a colonizer who does not want to be a colonizer." 22

The overriding motif, or central symbol, in Coetzee's writing is the conception of South Africa as a garden. Although he attacks the organicist metaphor, Coetzee is culturally deeply implicated in the process of supplanting peoples that took place in the colonisation of South Africa. From the outset of the white presence in South Africa with the planting of a European settlement at the Cape of Good Hope in 1652, the colony had a purpose which was intrinsically tied with the land: to provide fresh produce for the East India trade between the Netherlands and Asia. The colony was run by the Dutch East India Trading company which did little to encourage settlement in the hinterland of the Cape which it believed to be inhospitable, populated by primitive Bushmen (San) and Hottentots (Khoi). Early reports had shown little sign of mineral resources. Over the 
subsequent 150 years the colony came under the rival influences of both the British and French empires and despite continuing discouragement from the Trading Company, the hinterland began to be settled by those who would become the white Afrikaners. As a nation of colonists the Afrikaners sought to preserve their own identity in a form of pastoral colonial "exodus". The imperial colonial notion of an Adamic return to a garden of Eden failed to take hold. As Coetzee puts it in the introduction to his book of essays White Writing: On the Culture of Letters in South Africa:

For a while the promise of a fresh start on a fresh continent deeply affected the shape of history in Europe's New World colonies, in South Africa, in many respects a lui-lekker land (land of ease and plenty), the only myth that ever came to exert a comparable animating force was the story of the wanderings of the Israelites in search of a Promised Land, a story of tribal salvation appropriated as their own by the wandering Afrikaner tribes. ${ }^{23}$

Colonialism driven by the ideal of the progress of man and the prospect of paradise stimulated by the geographical and imaginative impetus of the Renaissance never took hold in the Cape. Relatedly, the rhetoric of imperialism never constructed South Africa in the form of a terrestrial paradise as it did many of its early colonies, neither did South African immigrants desire the country to serve as Europe's pasture or a colonial spiritual "hothouse" that was projected by the more optomistic puritan colonies of, for example, New Zealand and North America. For the West, South Africa remained a "historical backwater" until the coming of the British in 1795, and even then its colonialism was constructed under the threat of a return to brutalism, rather than the promise of a JudaeoChristian return to Eden. As Coetzee again puts it:

The Cape, by contrast, belonged not to the New World but to the farthest extremity of the Old: it was a Lapland of the south, peopled by 
natives whose way of life occasioned curiosity or disgust but never admiration. It struck neither the trading company that administered it nor the prosperous public of an underpopulated Netherlands as a place with much to offer the settler or the investor. ${ }^{24}$

In Life and Times of Michael K, Massachusetts Governor Winthrop's theory of the "double right", in which precedence for cultivators of the land over nomad hunters was used as the moral right for the assertion of Afrikaans' pastoral supremacy, is inverted and a founding tenet of what was to become a brutal and corrupt South African society of apartheid is undermined and parodied by the biblical proclamation that the meek (here in the form of disfigured, simple, and abused Michael) shall inherit the earth. As Michael Marais points out: " . . the act of reading Coetzee's novels becomes a political allegory of the capture and containment of colonial space and its people... Throughout Coetzee's work, the text's resistance to such interpretive strategies of containment serves as a political allegory of the colonised's escape from the political programmes of containment." 25

The novel opens with Michael's birth. The narrator in this, the first, book has a limited omniscience. Hare-lipped, facially disfigured and simple, he is from the first a figure of charity. The son of a Cape Town housekeeper, Anna K, his pre-school youth is spent "... sat on a blanket watching his mother polish other people's floors, learning to be quiet" (4). He is given schooling by the protection of the State in the company of other "variously afflicted and unfortunate children" (4). At fifteen he joins the municipal services of the City of Cape Town as a gardener, leaves after three years, then experiences a period of unemployment ". . . which he spent lying on his bed looking at his hands." He takes a job as a night attendant in the public toilets, is beaten up, returns to work at Parks and Gardens, and rises to become "Gardener grade 1".

Thus the garden theme and Michael's primal innocence is introduced by Coetzee in conjunction with the theme of racial ambiguity. Throughout the novel we are never told whether Michael is black or white. In Kafkaesque manner he is given no surname and 
very little self-determination. We conclude that he is black by his social status and the manner of his treatment by others but this conclusion is reached only by our knowledge that the novel is set in a "real" South Africa, albeit one of the near future. The issue of Michael's skin colour is obscured or masked by the distinction of his disfigurement, and it is by this means that Coetzee both sidesteps the issue of race and emphasises it by its "presence" as a lacuna in the text. Michael's racial ambiguity and Coetzee's strategies of narration serve to detach the narrative from fixed white South African textural constructions, from white South African myths.

In Michael $K$, Coetzee portrays a simple protagonist whose identification with the earth and with the act of growing is far closer than with his fellow beings. Michael seems "untouched by history" and set outside time. As Berger does with G, and Lively with Claudia, Coetzee places his protagonist as far to the outside of history as his context will allow.

Michael's life is constantly interrupted, jarred by the intrusion of others who bend his "ideal" world to their will. The grandson of the former farmholder returns to hide away at the farm, having deserted from the army. He talks of bands of mutineers and resistance fighters with whom he does not want to be associated, having "made his peace", and mistakes Michael for a caretaker appointed by his family to look after the farm. He sends Michael on an errand for food and Michael retreats to a cave in the hillside, fearful that his planting may be discovered, all the while neglecting his plants in the sun. However, he seems to exist in a semi-delirious state, brought on by his increasing hunger and isolation; it is as if the consciousness that Coetzee gives him is one which is not quite of this world. For Coetzee's Michael K, hunger is a metaphor for a spiritual quest: "He wondered if he were living in what was known as bliss. There was a day of dark cloud and rain, after which tiny pink flowers sprang up all over the mountainside, flowers without any leaf that he could see . . . As a child $\mathrm{K}$ had been hungry . . . Hunger had turned them into animals who stole from one another's plates ... Then he had grown older and stopped wanting" (68). 
Michael undergoes a series of punishments at the hands of others, each of which dirupts his "natural" life, and which become internalised by his refusal to eat, his passive resistance to the forces of society "outside". He eventually descends from his hillside retreat into the town of Prince Albert, where he is questioned by police and interned in the hospital of Jakkalsdrif, a labour camp for vagrants and for families displaced by the civil war. Here $\mathrm{K}$ gradually adjusts to encampment life, although all the while desiring to escape and return to living on the land. But as he is informed, if he does escape he will become no longer merely "homeless" but a criminal, and likely to be jailed. His simplicity, his apolitical attitude, is taken for a baby-like naivety: "'You've been asleep all your life. It's time to wake up. Why do you think they give you charity, you and the children? Because they think of you as harmless, your eyes aren't opened, you don't see the truth around you"' (89). Michael is referred to as " $K$ " throughout the narrative dealing with the camp and subsequently, as if to further reinforce his anonymity against a background of political intrusion. Like Berger's G, Michael enacts a retreat from politics, but for Michael the retreat is into a form of agoraphobia, rather than sexuality. His patience is the patience of the land. In a final allegory he imagines a way of living in companionship with an old man, for whom he draws water out of the well with his spoon. Thus the novel turns full circle in an echo of its opening, where Michael is spoon-fed as a baby by his mother.

Life and Times of Michael $K$ is a mixture of allegory and dystopia. There is a purposeful obliqueness in the novel which attempts to deconstruct the genre of realism and in so doing to enact a form of textual decolonisation. Since apartheid in South Africa forces the writer, wittingly or not, into a political stance, because the politics of the nation is so pervasive that the culture and discourse is already always politically primed, Coetzee writes a counter-discourse. While Michael $\mathrm{K}$ might be an apolitical figure, it is impossible to be an apolitical figure in a state like South Africa, or even as it is imagined in the near future. As in Berger's $G$., the very emplotment of K's political neutrality implicates those who interpret him as a potential threat. Even attempting to step outside 
discourse, to remain "silent", becomes a political act in so far as it is an act of "difference" to the political norm.

Because of narrative ambiguity, Coetzee's Life and Times of Michael $K$ is a novel that it is possible to construct anew with each re-reading. What is continually being re-written is the existing set of discourses and political values. In his parodic version of the South African novel of the land, Coetzee attempts to visualise a response to the African landscape quite apart from the politics and discourse which hitherto have governed such readings and confined them to binary terms which prevent any genuine "white" identification with landscape or territory. The novel, like the earlier Waiting For The Barbarians, attempts to suspend normal time, and in so doing to escape the roles that force people into "societies" of mutual opposition. Simultaneously, the novel is an allegory of the military state. Again, as Watson puts it:

If, indeed, there is a dominant moral impulse at work in Coetzee's novels, it is to be found in the insatiable hunger of all his protagonists for ways of escape from a role which condemns them as subjects to confront others as objects in interminable, murderous acts of selfdivision. If there is also pessimism in them, it is because the majority of these characters (Michael $\mathrm{K}$ being the exception here) beat against the shackles of their historical position in vain. 26

The epigraph of Michael K comes from Heraclitus:

War is the father of all and king of all

Some he shows as gods, others as men.

Some he makes slaves, and others free.

Like Nadine Gordimer's July's People (1981), Michael $K$ anticipates the impending chaotic dissolution of white-ruled South Africa. Coetzee concentrates in Michael $K$ on 
the institutionalised violence of South Africa. Michael $K$ attempts to pave the fictional ground for a transcendent South African literature in which while "War is the Father of All", it is not the ruler of all. It is an apocalyptic vision which nevertheless suggests the possibility of a South African cultural transcendence.

\section{Fantasy and biculturalism: Keri Hulme's the bone people}

the bone people concerns the fortuitously interconnected lives of members of a postcolonial "family" comprising a Maori man, his adopted and autistic mute son, and a Pakeha-Maori woman, who form, disband and re-form according to the pattern of an odd but meaningful relationship played out against a backdrop of Pakeha and Maori mythology.

The popular and critical success of the bone people, its national and international acclaim, provoked a divisive reaction in a self-conscious New Zealand literary community. This has acted as a catalyst for the re-examination of a New Zealand identity in the light of women's movements and the Maori Renaissance. Much of the debate centred perhaps unnecessarily on the worthiness of the author to write as a Maori New Zealander. The status of the novel as an indigenous work became quickly entwined with issue of its literary authenticity. It was as if the critical success of the novel was pinned on the willingness with which Hulme's readers would ascribe to her a Maori identity; the novel's literary worthiness a measure of the authenticity of its author's voice and the degree to which what remains a disturbing, unusual novel could be assimilated into a community which was still negotiating the complexities of its biculturalism.

Born in Christchurch, and having spent much of her life on the South Island West Coast, Keri Hulme is of mixed ancestry: Maori (Kai Tahu), Orkney Island, and English. She has one great-grandparent who was a Maori. For prominent white male New Zealand author and critic C.K. Stead, this isn't enough to ensure her indigenous status. Contesting the award of the Pegasus Prize for Maori Literature to the novel, Stead wrote: 
Hulme was not brought up speaking Maori, though like many Pakeha New Zealanders she has acquired some in adult life. She claims to identify with the Maori part of her inheritance-not a disadvantageous identification at the present time - but it seems to me that some essential Maori elements in her novel are unconvincing. Her uses of Maori language and mythology strike me as willed, self-conscious, not inevitable, not entirely authentic. Insofar as she is an observer of things outside herself, Hulme has observed Maoris and identified with them. If that is what constitutes a "Maori" writer, however, then Pakeha writers like James K. Baxter and Roderick Finlayson (to name two obvious cases) could be said to have been more successfully "Maori" than Keri Hulme ... the bone people, I would be inclined to argue, is a novel by a Pakeha which has won an award intended for a Maori. ${ }^{7}$

Stead goes on to say that the winning of the award, sponsored by the Mobil company for a novel or autobiography by a Maori, written in the past decade, in English or Maori, is not Hulme's "fault". Instead he questions the inaugurators of the Prize for conceiving a Maori award, and the criteria by which they expressed what is a patronising "affirmative action" towards a disadvantaged group. Stead questions the appropriateness of Hulme's winning of the prize by virtue of her racial antecedents, and also the conception of a literary prize based on any authorial antecedents whatsoever. He cites Witi Ihimaera as one Maori author who refused to enter his work for the award for such political reasons. The literary stature of Hulme's novel becomes entwined with the politics of prize-giving.

Writing before the bone people won the Booker Prize, Stead does not, however, completely dismiss it, suggesting that the bone people is at the core a work of great simplicity and power. What interests Stead most is that the relationship of the characters is achieved outside of a biological connection. Joe Gillayley's own wife and child have died, he has an adopted Pakeha son who, shipwrecked, has literally been washed ashore and into his arms. There is a kind of love between Joe and Kerewin Holmes but this love 
is never sexually consummated. There is also a kind of parental love between Joe and Kerewin for Simon. As Stead points out, the novel is one of division: a sexual union where no sex occurs, parenthood without physical parents, the emotional complexities of family where there is no biological family. As a metaphor for a troubled and complex bicultural nationhood this interplay of absences is not without significance. The overall picture Stead creates is of an interesting though troubled novel, with a dark violent centre, "a novel fuelled by its lack." 8 The novel functions as a metonym for post-colonial displacement.

Hulme, in her volume of short stories Te Kaihau (The Windeater) (1986), her collections of poetry (The Silences Between) Moeraki Conversations (1982) and Strands (1992), and in the bone people, explores language as an interface between Maori and Pakeha cultures, between a troubled colonial past and a difficult present in which the problems of the past, the cultural collision and collusion between Pakeha and Maori cultures, are negotiated with a tense concern. This is a cultural climate that is stirred from the mythologies and cultures of both racial groups. The novel is fundamentally nostalgic and sentimental about Maoritanga. Written in English and in Maori, (with a glossary of Maori words) it does not aim at a synthesis, but seemingly at a dialectical balance in which differences are encoded.

Graham Huggan suggests that "Kerewin's very speech is a kind of 'creole', an unusual but identifiable combination of Elizabethan archaisms and contemporary vernacular interspersed with arcane allusions, colourful regional idioms and Maori proverbs." 9 While her speech may be identifiable in terms of an accumulation of these disparate and multiple elements or a combination of them-she speaks both Maori and English - the two forms are juxtaposed, they are not assimilated into a third kind. "There is just about everything in her library" and Kerewin herself distinguishes between her knowledge of Maori and English language: "This godzone babytalk. Hottie lolly cardie nappy, crappy the lot of it, she snarls to herself", and "I don't think I'll disclose meantime that I can speak Maori." Huggan applies the term to Kerewin's speech in 
support of a larger reading of Brathwaite's revisionist term "creolization" as a metaphor for post-colonial textual interpretation:29

which ultimately implies neither a perpetuation of 'white' (ex-colonial) values or a recuperation of 'black' (indigenous) values within the postcolonial society but an interculturative process within which a series of intermediary postures are struck up that elude or actively work against the binary structures (white/black, master/slave) which inform colonial discourse but which have also survived in modified or transposed forms in the aftermath of the colonial era. ${ }^{30}$

While Huggan's definition of creolisation provides a useful interpretation of Kerewin's language, and to some extent of Hulme's wider concern in the bone people, the novel does not quite enact the intermediary posture which eludes the binary structure which Huggan suggests. While Kerewin and Joe are neither pure "Maori" nor pure "Pakeha" they are not necessarily "creole" either. The bone people does not posit a "third" mode of existence, but rather a negotiation "in limbo" between the two and there is no necessary sense in the novel of a new national "creole" New Zealand identity. The relationship between the characters is not that of binary, black or white, and to this extent, both Kerewin and Joe are post-colonial hybrids; they are mediated by a mute child who understands both Maori and English, who can articulate neither, and who speaks in sign language. While the unspoken and largely unrealised (the "family" is broken up to be re-united again) implication of the bone people may be in the nature of a "hybridity", the textual realisation is not. Creole usually refers to Europeans born and naturalised in the West Indies. Hybridity involves the making of a new form which combines the characteristics from two or more old ones, the grafting of one form on another, whereas creolisation describes the process of adaption of a transplanted culture in a new environment. Writen under the sign of authenticity, the bone people arguably enacts a form of liberal discursive violence by attempting to define and contain matters 
authentically Maori within a narrative that argues the shifts in balance and sensibility toward a Pakeha biculturalism. In doing so the possibilities of indigenous representation of the post-colonised discourse are contained by the discourse of the post-coloniser.

The novel is interwoven with references to fantasy novels: "Stow the book on cooking fish. Gimme something escapist, Narnia or Gormenghast or Middle Earth, or . . ." (16) The novel sits uneasily at the cusp of Maori and Pakeha cultures. References are made to European novels and mythologies and Maori language and mythologies. the bone people is neither exclusively Maori nor Pakeha, but a novel that explores the interaction of peoples who belong to two or more cultures, of indeterminate characters. The degree to which her audience is willing to let Hulme write for either culture acts as a kind of measure for cultural tolerance and the willingness to enter the negotiation of a hybrid New Zealand identity:

'It's very strange, but whereas by blood, flesh and inheritance, I am but an eighth Maori, by heart, spirit, and inclination, I feel all Maori. Or,' she looked down into her drink, 'I used to. Now it feels like the best part of me has got lost in the way I live.'

Joe was very still; so softly, that it was almost on a level with his breathing,

'That's the way I feel most of the time.' More loudly, 'My father's father was English so I'm not yer 100\% pure. But I'm Maori. And that's the way I feel too, the way you said, that the Maoritanga has got lost in the way we live' (61-62).

Hulme reinvigorates a national culture with myth. However, as Margery Fee argues, whereas "[f]airly widespread agreement exists in the academic community that the biological contribution to race, gender and class differences is negligible: these differences are, rather, strongly rooted constructs", she also suggests that the insistence 
of an indigenous ancestry provides "a safeguard against the frequent facile exploitation of indigenous material by White writers." ${ }^{31}$

The "problem" with Hulme's novel is that it speaks for both Maori and Pakeha cultures, and to neither to the exclusion of the other. The finding of Simon's sandal and Kerewin's possessive reaction to the intrusion on her solitude in her tower make a Robinson Crusoe-like reference. There is also a strong familiarity with Shakespeare's The Tempest. The themes of isolation, transformation through magic, and recovery of lost kingdoms developed through the latter narratives are echoed in the bone people. However, having established expectations of literary intertexts, Hulme leaves them open, refusing to close familiar patterns of identification.

The Maori mythology of the novel is not invoked to retrieve an essential Maori past. Hulme is not necessarily claiming that a pure pre-colonial sense of Maoridom is literally recoverable, but rather seeks to juxtapose Maori with an Anglo-Western mythology, in particular Celtic and medieval fantasy elements, in an occidental narration which inconclusively consumes the Maori. Maori mythology forms the subtext of the novel. When the remnants of the ancient Maori canoe are buried under rocks during an earthquake, buried with them is the notion of a pure Maori past. Redemption is suggested symbolically, however, through the figure of the Mauri. As long as the Mauri is guarded from one generation to the next, the symbolic hopes of the tribe remains.

The central symbol of the novel is the spiral. Its use denotes growth, birth, and replication - both outer and inner lives. Kerewin inhabits a spiral structure she had built from the proceeds of a lottery. The narrative too has a spiral structure as the fate of the three narrators interweaves, breaks and recombines-and the beginning and ending of the novel have a double spiral in perpetual interchange "the spiral made a useful thoughtfocus, a mandala, anyway ... It was reckoned that the people found inspiration for the double spirals they carved so skilfully, in uncurling fernfronds: perhaps. But it was an old symbol of rebirth, and the outward-inward nature of things ..." (45)

The use of symbolism in the novel is heavy-handed almost to the point of contrivance. Symbols are littered throughout Kerewin's mystical world. She reads them with an 
astrological superstitiousness. However, their significance is perhaps overdetermined in the novel. Maori mythology and symbol are depicted as inextricably bound. Identification with Maoridom is signified by the ability to read these symbols, whereas there is a strong historically recorded figurative quality in Maori art and culture that the novel overlooks. As Roger Neich has pointed out in Painted Histories (1993), the stylistic element in Maori culture in which motifs are used for purely decorative purpose, is at least as strong as the use of symbolic meaning. ${ }^{32}$ It is as if in the bone people Hulme overdetermines Maori symbolic referencing. At least, she incorporates it into her own world in an overdetermined manner.

Joe, having more claim to "Maori" ancestry than Kerewin, is nevertheless more sceptical of superstitions than is Kerewin-his fear is tempered with a more straightforward rationality. When he meets the elder who has "guarded" the ancient canoe burial site and who apparently has been awaiting him, he enters into a world of Maori myth directly, yet the manifestation remains literal. And so there is the Mauri from which he experiences a magical kind of "electricity" or possibly a sexuality: "It's like ten thousand tiny bubbles bursting on his skin, a mild electric shock, an aliveness . . like an ice-cube melting in whisky and spinning out lucid threads into the surrounding cloud" (367). When the canoe site is buried by earthquake he takes "the south road home," (385) and it is as if he has laid a ghost to rest. There are two sides to Joe, then: a half believer with one side superstitious, mythological; the other rational. He takes with him the talismanic disk, the Maori relic that remains from the site: "It looks very black or very green, and from the piercing, the hole in the centre, light like a glow-worm, aboriginal light" (384), but at the same time has no qualms in leaving: "Not to worry, man, this is someone else's place now" (385). It is at this point that Hulme's novel makes the greatest demand on the reader's credulity. K. O. Arvidson describes the passage as being evocative of "the 'aura' of romance." 33 'Arvidson explains the purpose of this kind of neo-medieval romance language employed by Hulme as a desire to reinforce the notion of a vital Maori spirituality with regard to people and the land, the ancestors, or the past, in a context where Pakeha readers "might not have looked for spiritual values": 
It is undoubtably one of the purposes of this kind of writing, perhaps the major purpose, to assert the survival of Maori spirituality and to stress its difference from the Judaeo-Christian tradition. Part at least of the stylistic excess with which this is done is arguably due to what from the viewpoint of a structurally hierarchical religion like Christianity seems like a de-centred diffuseness in Maori spirituality, as a consequence of which, if spiritual value is to be asserted in any one form rather than equally in all, the assertion must be made as loudly as possible. In a sacrilized world it requires some special pleading, a special tone of voice, to insist on the especially sacred character of a greenstone patu, for example, or a mauriora or a poupou. This line of thought is not offered by way of justifying the jarring stylistic incongruities and excesses this gives rise to in much Maori writing, but it is a way of trying to understand what is going on when a characteristic air of strain appears and the writing becomes overheightened (124).

Arvidson's point, and here he includes the writings of Witi Ihimaera and Patricia Grace, is that the adoption of the mixed genres in Maori writing, of epic or romance is symptomatic of a literature which tries to regenerate a feeling for ancient literary modes, formerly those of oral storytelling within the context of a contemporary Maori literature. In effect, the style is post-modern, a simulacrum, evocative of an ideal that never in fact existed. Hulme progresses from a particularly uneasy vision of New Zealand's biculturalism to a utopic vision of multiculturalism that frames the novel's beginning and end. Arvidson argues that Hulme borrows from and appropriates the romance of Tennyson which is recontextualised in a Maori tradition. The heightened passage about the Mauri that Arvidson concerns himself with he also describes as "not at all untypical 
of Hulme's style in the bone people, with its extremes of violence and illness and alcoholic states, all written on top of the author's very considerable intensity. "34

However, it is difficult to see how the multiple ancestries of Simon, Kerewin and Joe are "integrated"; they are juxtaposed, entwined, but there is little evidence of integration be it physical or metaphysical. As Anna Smith has put it, they are "love's wounded beings": "Hulme's narrative is marked by an absence of the idealising discourse necessary for intimacy between two people to flourish." 35 The pivotal character between Kerewin and Joe is the child Simon, but he is autistic and cannot speak.

the bone people is idiosyncratic, juxtaposing rich and poetical word combinations that combine the fantasy element with the local; a European medievalism with Maori language. The novel never quite abandons a sense of the parochial, however. This is a weakness in that this evocative language, redolent of a particular New Zealand coastal experience subsumed in an authorial mysticism, is undermined by the fantastic turn of events. This mysticism is a feature of the strong third-person narration, steeped as it is in the consciousness of Kerewin. When the novel departs from this claustrophobic consciousness, for example in part four which deals largely with Joe, the binding thread is lost, and the cloak of the character is shed, leaving the author's "fantasy" exposed.

Themes of isolation, despair, and an epic loneliness are the common threads that tie the ethnicities of Hulme's novel together and belie the novel's parenthetical vision of a multi-cultural Pacific utopia. Paradoxically, it is the novel's silences that articulate these pessimistic themes most forcefully. Silence forms an intermediary barrier between a material world, a harsh pragmatic world, and an emotional world. The silences reflect the frustrations of a nation struggling for the expression of a post-colonial identity. The muteness is a signifier for the "lost" language of colonial and post-colonial New Zealand affect, signifying the narrative voids in history as cultures slip past one another. It is also a signifier for the lost narratives of mutual complicity that sink between those of traditional and recorded histories. 


\section{Colonial Folly: Peter Carey's Oscar and Lucinda}

Peter Carey's Oscar and Lucinda is concerned with the origins of white Australian nationhood, with cultural and spiritual dislocation but also with territorial relocation and the impact of modernity in a pre-modern land. Carey presents an image of colonial Australia for the nation's bicentenary. However, this image is a fiction, an invention, for as Richard White points out, "There was no moment when, for the first time, Australia was seen 'as it really was'. There is no 'real' Australia waiting to be uncovered. A national identity is an invention." 36 If one accepts White's statement as an accurate reflection of the problem of the attempt to depict the "real" pre-colonial Australia, Carey's novel offers a post-colonial counter-discourse of Australian colonial history, a discourse which contrapuntally attempts to un-write and re-write Australian colonial history. However, as C.K. Stead points out, there is a danger that such a counter-discursive mode will be somewhat vacuous. This vacuity may well be a problem of all post-colonial re-writings of the colonial era in which the dominant values of the contemporary are juxtaposed (unfairly) with the those of the past. As Stead puts it:

Careyland in Oscar and Lucinda is not just one place. It is partly historical reconstruction, partly mythical world, and partly a set of very up-to-date opinions. Carey is dutiful about (what else in 1988?) racism and sexism. Women and blacks are victims. That is one reasonable and well-supported historical view from the perspective of 1988; but it is not reasonable to have women and blacks of the 1850's share that perspective. Those up-to-date opinions begin to invade and undermine both the history and the myth—not because they are "wrong" but because they are out of place. They destroy the credence on which the fiction depends. 37

The image that Carey portrays of Australia in his earlier novel and Booker Prize nominee Illywhacker (1985) and in Oscar and Lucinda is that of a brutal society founded 
on lies, gambling, folly and greed. It is vision that encompasses the middle-class Anglophile intelligentsia (as represented by Oscar), the monied pioneering upper-middle class in Lucinda, and the colonial "Other" in the Aborigine or "darkfellow" who is referred to at numerous points in the novel but not given a distinct identity. Carey satirises, questions, and re-reads colonial Australian New South Wales society, reinscribing it in post-colonial counter-discursive form. To this extent the society which Carey portrays is a simulacrum-a copy for which there is no original. The plight of the Aborigine or Koori remains largely the un written and unexplored tragic subtext of the novel.

If Carey's Illywhacker parodies a colonial and post-colonial Australia as a history of "white" lies; Oscar and Lucinda takes this reading a step further in chronicling a bicentenary of conspicuous and profound misunderstandings. However, even with a novel as purposefully culturally brutal as Oscar and Lucinda, its counter-discursive mode works to perpetuate the discourse of the colonial narrative. The recognition of a history of lies and misunderstandings (including the lie that the country was empty or unclaimed when the whites arrived) does not correct those follies; in fact it may well even celebrate them in the Australian "mythos" of the "great lie".

In support of the concept of counter-discursive writing, Helen Tiffin claims: "the operation of post-colonial counter-discourse is dynamic not static: it does not seek to subvert the dominant with a view to taking its place, but . . . to evolve textual strategies which continually consume their own biases at the same time as they expose and erode those of the dominant discourse." 38 Counter-discourse thus works to undermine essentialist views of regional or national discursive formulations while purportedly opening up a plethora of possible intra and inter-cultural perspectives.

To what extent can the hegemonic influences of the literature of one era (colonialism) be said to be corrected, undermined, or replaced by the "counter-discursive" rhetoric of a subsequent post-colonial era, when the authorship of both sets of ideas remains largely static - that is, originating from the culture of the Anglo-Western European? To what extent is the "Other" liberated by the semiotic liberation that counter-discourse attempts? 
Carey shows in Oscar and Lucinda that what seems at first to be a widening of cultural horizons, a re-addressing of the follies of a barbaric colonialism, is in fact the reappropriation of the colonial impetus in a post-colonial form.

Huggan suggests that Carey's counter-discourse disassociates itself from a eurocentric ideology which may "consume its own biases": firstly, by "parodying the rhetorical strategies implemented by the 'first' European explorers and settlers, thereby effecting an 'undiscovery' of the 'New World' which leads to the rematerialization in its supposedly blank spaces of the suppressed discourses of aboriginal culture; and, secondly, by propelling his protagonist into the self destruction which awaits those who are congenitally unable to distinguish between their life and their dreams." ${ }^{39}$ However, this reading remains incomplete in the text, for it is only contrapuntally that we imagine in it the novel's "Others". Certainly, Oscar becomes unable to distinguish between his life and his dreams, his ideals and his reality, whereas Lucinda, we are told at the novel's conclusion, becomes a leader in the early Australian women's labour movement. Apart from this afterthought there is no resolution in the novel with regard to Carey's "Others". The blank histories are left blank.

Sympathetic as it is towards the unannounced histories of the Aborigine and women, and ironic and damning in places (as well as in overall allegorical function) of the European colonisation of Australia, Carey's novel does not "rematerialise", in the blank spaces of history, the suppressed discourse of Aboriginal culture. Nor, by putting Oscar to death in mock sainthood inside his sinking glass church, does Carey avoid a selfreflexiveness that is a part of his counter-discursive mode. His novel is, however, more "counter-discourse" that many other Booker Prize winners. The problem is: can the contemporary author, condemning colonial errors, entirely avoid a complicity in the narratives of imperialism? As Stead observes:

not in method but in what it shows, Oscar and Lucinda departs from its nineteenth-century precedents. These are the harsh truths which Victorian prudery and sentimentality concealed; but the effect of the 
telling here is not one of liberation. The narrowness of focus, the feeling that imaginer and imagined are perilously close, produces the sense of something treacly and distasteful. Have we moved from nineteenth century evasion to twentieth-century truth-telling; or is it merely a side-step into melodrama? ${ }^{40}$

The harbour down which the church is floated is an outpost of empire in which Aborigines and clergy are treated with like brutality, bringing out brutality in Oscar as he kills Jeffers. The "horror" of Conrad's Heart of Darkness becomes Stead's description of Carey's novel as a vision of Australia as the world's arsehole: "When Oscar resolves to assert himself against his tormenter he is stopped by the sight of the overseer buggering the carpenter by the light of the campfire." 41

The glass which concentrates sun in watery London is impractical in blazing heat of New South Wales, as is pointed out by Charles Ahearn before it is built. In a midtwentieth century postscript to Oscar and Lucinda the church is removed, absent; the Christian stories that Oscar brought with it to Bellinger are lost, like Aboriginal stories which they themselves replaced. The church is carried overland to Boat Harbour, sunk in the Bellinger river, reconstructed as the weatherboard building that the narrator's mother cherished at Gleniffer in 1930s, and in turn removed in the 1980s to Bellinger to serve as a Sunday school. As Huggan observes the church becomes:

symbol of their own fated love and a solitary reminder of the misguided idealism which attended the 'founding' and forming of the new crown colony of Australia . . . the church is the novel's allencompassing embodiment of risk, encapsulating the hopeful but unprincipled industrialism of Lucinda's glassworks, the ambitious but imprisoning materialism of the giant transoceanic liner The Leviathon on which she and Oscar met for the first time, and the calculated but, by its very nature contingent gambling of Oscar. ${ }^{42}$ 
Oscar and Lucinda's first meeting on The Leviathan carries suggestions of a parody of both Hobbes' philosophical treatise on the nature of society with its accent on "absolute government" and "simple obedience" and intertextually with Melville's epic novel, Moby Dick. Lucinda first lays eyes on Oscar as he is being manhandled backwards down a gang plank from the ship. He is thus a figure of tragedy and comedy from the start.

Anthony Hassall suggests that "the introduction of historical figures as 'characters', such as Lucinda's meeting with George Eliot, has the contradictory effect of foregrounding the artifice of Oscar and Lucinda while at the same time rendering it plausibly 'historical'. When the historical figure is herself a novelist, there is the further double take of inventing a fictional life for an inventor of fictional lives."43 However, although it does reinforce the metafictionality of the novel, the manipulation of history does not render it any more historically plausible. Carey is using fiction to "subvert" fact and the product is not an historical realism but an overlay of fiction on fiction. As Lorna Sage puts it: "Peter Carey has been hailed as an original. In fact, nothing could be further from his intention: he's deeply and deliberately unoriginal, bent on un-discovering things, in particular his native Australia, but also the narrative strategies of the novel." 44 Everything in Carey's novel of white Australia stands in the place of something else, not necessarily metaphorically, but in indication of the absence of an original.

History as pastiche, then, defines the implied Australian cultural present in Oscar and Lucinda. It could be argued that the novel is therefore as much about the contemporary Australian psyche as about the colonial era it seeks to depict. The sense of the historical is rendered absent through the contemporary gaze which constructs Australia as inherently white and formerly colonial. This reading is regenerated when the postmodern nostalgia mode of the present brings the historical absences of Aboriginal peoples and women into play. The absent past contrapuntally represents a two-hundred-year cultural "lag" in the pages of the novel.

Thus, while inherently post-colonial as a re-reading of colonial genres, Carey's novel is also post-modern. It is a metafictional parody of Australian colonialism and 
participates in post-colonial discourse in so far as it not so much re-reads two hundred years of colonialism as suggests the conditions which necessitate its re-reading.

Carey is thus concerned with a colonial dystopia in Oscar and Lucinda. The novel represents a re-writing of colonial history in terms which reinscribe early Australia with a contemporary consciousness which systematically subverts the positive values of empire.

The central question Carey's novel then poses is: for what reasons was Oscar and Lucinda's Australian church built? Rhetorically, the novel answers: for love, for their ideals, for what must be read as corrupted Christian ideals, and for a bet. Carey's story of grandiose colonial folly is an ironic reflection of an Australian "Crystal Palace". Its miniature, crafted chapters are like panes of glass forming the superstructure of the novel, each housing its collections of portraits, landscapes, and drawings. Like Paxton's Crystal Palace of London, Oscar and Lucinda's "palace" is also transported and eventually destroyed, Oscar and Lucinda's church sinks into the water, bearing with it Oscar to his mock-sainthood death in a colonial scene of Ahab-like pathos.

\section{Conclusion: Visions of Disharmony}

Naipaul, Gordimer, Coetzee, Hulme and Carey are post-colonial pessimists. They offer complementary visions of cultural disruption and racial disharmony in the aftermath of empire. The nations they envisage are corrupted by the incompatibility of indigenous values with those of the invading culture and the erosion of ritual, communalism and tribalism by secular capitalist individualism.

Like the Raj novels, those of the "post-colonial pessimists" are essentially negative or disparaging of the prospects for meaningful and harmonious cultural interaction. They reflect the inability of the British to consider other cultures on anything but British terms and the corresponding difficulty of establishing new cultures from underneath policies of segregation or assimilation. For the British, the perception is that in their absence the result is chaos and disorder. For the non-British anti-nationalists, communalism and material backwardness are sources of weakness calling for a curious and sometimes dangerous blend of acceptance and rejection of the invading culture. 
In V.S. Naipaul's In A Free State there are no "free states", be these defined mentally or geographically. There is merely a multiplicity of post-colonial and colonial banalities, cruelties and excesses. Freedom is a term of mockery for colonised and coloniser who are caught up in a complex web of entanglements which Naipaul's cynical entrenchment seldom reconciles beyond a pessimistic sense of futility. Naipaul demonstrates an inability in his fiction to reach beyond a fixity of view in which he regards societies as static environments which harbour inauthenticities. He refuses to acknowledge a rival vision which recognises a fluidity and the negotiation of the post-colonial condition that would allow society to evolve with a sense of cohesive identity and nationhood. Naipaul is caught at the cusp of a world moving from colonialism to post-colonialism and his pervasive nihilism does not allow his readers to move beyond this stage of transition. $\mathrm{He}$ portrays the "stasis" of the post-colonial culture. His fiction oscillates between polarities of violence, humiliation, displacement, and denial which he explores with a penetrative and dark irony. The title of his Booker Prize winning novel is all the more ironic for this. In a post-colonial literary world of which Rushdie's "midnight's children" are in many ways the inheritors, Naipaul remains recalcitrant, unassimilable, and troubling but also darkly penetrating and continually challenging.

An example of one who exhibits unease with the established culture is J.M. Coetzee who, in the context of South African society which is a composite of First, Second and Third worlds, is a coloniser who explores the displacement that the colonising process brings about. Life and Times of Michael $K$ is concerned with the outcast and abject in the figure of the coloured Michael, and with a society of extremes that combines indigenous, settler, and cosmopolitan views. Africa, like the London of the cosmopolitans, is depicted by Coetzee as fractured, multiple, and sustaining a variety of perspectives. The idea of a unitary, stable colony of "empire" is split into fragments—changing and unstable elements that characterise the formation and reformation of national boundaries, just as the human subject becomes an unstable site of identity. Michael $K$ is an allegory of change and loss in the aftermath of colonial settlement. Coetzee combines a mystical African identification with land with the Western utilitarian view. 
In The Conservationist Nadine Gordimer, through the character of her industrialist weekend-farmer, Mehring, explores the burden of "white guilt": the attempt to seek identification with both land and the migratory black population; the attempt to reconcile white wealth with black poverty, 'civilisation' with nomadism; and the ultimately futile effort to reconcile these vast opposites in the white South African psyche. Under empire both the white British and indigenous black peoples were opposed by the South African Boers. The Boers sought to build their society as an act of defiance, seeing themselves both as victims of British imperialism and as the just occupants of African native territory. Mehring, their descendant, seeks an identification with the land that parodies and seeks to displace that of the indigenous peoples.

Gordimer explores the displacement of the white industrialist who seeks to identify with the country. The novel entwines themes of surveillance, appropriation and debasement of the South African post-colonial body and land. Like G., The Conversationist explores the attempt of its protagonists to evade politics, and to seek isolation from the forces that shape the societies around them, but the fatal flaw of each is their complicity with themes of alienation in their personal and sexual lives. Gordimer sets side by side a Western sense of absurdity and nihilism and African communalism and ritual, without wholly affirming either.

In The Conservationist Gordimer is pessimistic about the possibility for the realisation of a cohesive South Africa that is predicated on white rule; furthermore she is pessimistic about the possibility of retrieving a sense of belonging and identification in a nation dominated by people with values such as those as Mehring. Her vision is a contemporary dystopia in which individualism, greed and racial disharmony are the source of corruption. An understanding of, and connection with, an indigenous Africa, she seems to hint, is the only possible source of redemption for a society whichalthough now post-aparthied-remains violent and fundamentally flawed.

New Zealander Keri Hulme's 1985 Booker Prize winner, the bone people, is a novel whose central themes include hybridity and biculturalism. the bone people was controversial both domestically and internationally, and has been described as being 
"widely considered to be so impenetrable as to be a Booker panel's biggest error of judgement." 45 Dispute surrounded the reception of the novel within the New Zealand critical literary community. The nature of the controversy is only partly to do with the novel itself and more perhaps to do with the negotiation of identity in a bicultural New Zealand society, a society that defies the utopian vision of multiculturalism that the novel delivers as its revelation. The novel did much to both provoke and promote an awareness of biculturalism in New Zealand. This dispute gained international currency as part of the renaissance of first nation peoples among the former British colonies.

the bone people, written by a part-Maori New Zealand woman, was the author's first novel. It took twelve years to write, was initially rejected by publishers and later published as the result of the sheer persistence and will-power of a small publishing house devoted to women's literature, the Spiral Collective. the bone people represents an attempt to reconcile Pakeha New Zealand with Maori New Zealand and to find meaning in the interaction of cultures represented by its makeshift family. The novel is structured around a "family" made up of part-Maori Kerewin, Joe who is Maori, and Simon, Joe's autistic and adopted Pakeha son. The fluctuating and difficult relationship of these three can be read as a metaphor for a bicultural New Zealand, and for the negotiation of a New Zealand identity which encompasses both Maori and Pakeha mythologies in the attempt to progress from the binary model of race relations and to heal the wounds of colonialism. The novel concludes with a Pacific image-a vision of multiculturalism which the narrative and events of the novel do not sustain.

The novel met with an almost instant critical acclaim, winning both the New Zealand Book Award for fiction and the Pegasus Prize for Maori Fiction and, subsequently, the Booker Prize. For a novel which invokes a complex and hybrid New Zealand mythology, the story of its publishing and subsequent reception itself took on a mythological status: a Maori author and a feminist publisher battling a white maledominated literary world. Like Kingsley Amis's The Old Devils, an exploration of authenticity lies at the basis of the bone people. Where Amis is concerned with Celtic identity and the construction of Welsh difference within a wider Englishness, Hulme is 
concerned with the interaction of Maori and Pakeha identities. Both novels explore the condition of ethnic difference and the way modern societies promote ethnicities as a form of nostalgia for authentic pasts. However, the two novelists can be seen as opposites in so far as Hulme affirms a belief in the authenticity that Amis debunks. While Hulme is seemingly pessimistic about the ability of a bicultural New Zealand to retrieve an authentic wholeness, her novel is framed by a celebration of a multicultural Pacific that belies the novel's anticipatory doom for the loss of nativist culture beyond physical symbolism. A European sense of mystery and fantasy erode the novel's credibility to deliver a consistent and convincing vision of nativist or even bicultural renaissance.

Oscar and Lucinda is concerned not only with the origins of white Australian nationhood and with cultural and spiritual dislocation, but also with territorial relocation and the impact of modernity in a pre-modern land. Oscar and Lucinda's glass church, prefabricated in sections and transported overland to northern New South Wales, where it is floated across a river to its new location in Boat Harbour only to sink with Oscar inside, provides a dominant symbol for the colonial folly, ignorance, and excess that is Carey's offering to Australia as it celebrated its bicentenary. Carey's novel rediscovers a white colonial Australia founded on a mixture of gambling and greed. The post-colonial reflexivity of Carey's novel reflects an awareness of it own parodic nature, the silence in white colonial Australian history represented by the Aborigine, and signals the ultimate futility in attempting to retrieve essentialist pasts, be they those of the indigenous culture or that of the invader. These novels collectively express an awakening to the problems of migration and cultural intermingling. They articulate the mixture of nostalgia, regret and anticipation that underlies the colonial condition, especially the sense of past wrongs informing and corrupting the present. They also parallel the war of ideas raging over the possibilities for meaning in contemporary society and the relationship between language and objectivity that informs post-modern thinking. These pessimistic novels articulate the collective sense of foreboding that characterises the end of grand narrative of Enlightenment and modernity in contemporary post-colonial society. 


\section{Notes}

${ }^{1}$ Adewale Maja-Pearce, "The Naipauls on Africa: An African View", The Journal of Commonwealth Literature 20:1 (1985), p. 115.

2Maja-Pearce, "The Naipauls on Africa: An African View", p. 116

${ }^{3}$ Bruce King, V. S. Naipaul (New York: Macmillan, 1993), p. 92.

4Dennis Walder, "Reading in a Free State", Recasting The World: Writing After Colonialism, ed. Johnathan White (Baltimore: The Johns Hopkins University Press, 1993), p. 90.

${ }^{5}$ Selwyn Cudjoe, V.S. Naipaul: A Materialist Reading (Amherst: University of Massachusetts Press. 1988), p. 142

${ }^{6}$ Cudjoe, R. V. S. Naipaul: A Materialist Reading, p. 144

${ }^{7}$ Cudjoe, R. V. S. Naipaul: A Materialist Reading, p. 143.

${ }^{8}$ Cudjoe, R. V. S. Naipaul: A Materialist Reading, p. 145.

${ }^{9}$ Helen Tiffin, "V.S. Naipaul's 'Outposts of Progress'", World Literature Written In English 22:2 (1983), p. 309.

${ }^{10}$ V.S. Naipaul, In A Free State (London: Andre Deutsch, 1972), p. 9. All further quotations from this work are taken from this edition and are followed by the relevant page number in parenthesis.

${ }^{11}$ Maja-Pearce, "The Naipauls on Africa", p.115. The comment here is meant in a general sense.

${ }^{12}$ Robert Boyers, "Nadine Gordimer: Public and Private", Atrocity and Amnesia. The Political Novel since 1945 (Oxford: Oxford University Press, 1985), p. 124.

${ }^{13}$ Judie Newman, "Gordimer's The Conservationist: "That Book of Unknown Signs", Critique 22:3 (1981), p. 37.

${ }^{14}$ Irene E. Gorak, "Libertine Pastoral: Nadine Gordimer's The Conservationist ", Novel 24:3 (1991), p. 241.

${ }^{15}$ Gorak, "Libertine Pastoral", p. 249.

${ }^{16}$ Gorak, "Libertine Pastoral", p. 249. 
${ }^{17}$ Gray, "An Interview with Nadine Gordimer", p. 268.

18J.M. Coetzee, The Life and Times of Michael K (London: Penguin, 1985), p. 184. All further quotations from this work are taken from this edition and are followed by the relevant page number in parenthesis.

${ }^{19}$ Benita Parry, "Speech and Silence in the Fictions of J.M. Coetzee", Critical Perspectives on J.M. Coetzee, ed. Graham Huggan and Stephen Watson (London: Macmillan, 1996), pp. 57-58.

${ }^{20}$ Derek Wright, "Black Earth, White Myth: Coetzee's Michael K", Modern Fiction Studies 38 (1992), p. 439.

${ }^{21}$ J.M. Coetzee, intro. White Writing. On the Culture and Letters of South Africa (New York: Yale University Press, 1988), p. 11.

${ }^{22}$ Stephen Watson, "Colonialism and the Novels of J M Coetzee", Research in African Literatures, 17:3 (1986), p. 377.

23J.M. Coetzee, intro., White Writing, p. 2.

${ }^{24}$ Coetzee, White Writing, p. 2.

${ }^{25}$ Michael Marais, "The Hermeneutics of Empire: Coetzee's Post-colonial Metafiction", Critical Perspectives on J.M. Coetzee, ed., Graham Huggan and Stephen Watson (London, New York: Macmillan, St. Martin's Press, 1996), p. 81.

${ }^{26}$ Watson, "Colonialism and the Novels of J M Coetzee", p. 378.

${ }^{27}$ C.K. Stead, "Keri Hulme's "the Bone People," [sic]and the Pegasus Award for Maori Literature", Ariel 16:4 (1985), pp. 103-104.

${ }^{28}$ Stead, "Keri Hulme's "The Bone People," [sic] and the Pegasus Award for Maori Literature", p. 105.

${ }^{29}$ Keri Hulme, the bone people (London: Picador, 1994), p. 32. All further quotations from this work are taken from this edition and are followed by the relevant page number in parenthesis.

${ }^{30}$ Huggan, "Opting out of the (Critical) Common Market: Creolization and the PostColonial Text", Kunapipi, 11:1 (1989), p. 31. 
${ }^{31}$ Margery Fee, "Why C.K. Stead didn't like Keri Hulme's the bone people: Who can write as Other?", p. 12.

${ }^{32}$ Roger Neich, Painted Histories: Early Maori Figurative Painting (Auckland: Auckland University Press, 1993). The discussion here is in general terms.

${ }^{33}$ Ken Arvidson, "Aspects of Contemporary Maori Writing in English", in Graham McGregor and Mark Williams, eds., Dirty Silence: Aspects of Language and Literature in New Zealand: Essays Arising from the University of Waikato Winter Lecture Series of 1990 (Auckland: Oxford University Press, 1991), pp. 125-126. ${ }^{34}$ Arvidson, "Aspects of Contemporary Maori Writing in English", p.123.

${ }^{35}$ Anna Smith, "Keri Hulme and 'Love's Wounded Beings'", in Mark Williams and Michele Leggott, eds., Opening The Book: New Essays on New Zealand Writing (Auckland: Auckland University Press, 1995), p. 140.

36Richard White, intro., Inventing Australia (Sydney: George Allen \& Unwin, 1981), p. viii.

${ }^{37}$ C.K. Stead, Answering to the Language: Essays on Modern Writers (Auckland: Auckland University Press, 1989), p. 185.

${ }^{38}$ Helen Tiffin, "Post-Colonial Literatures and Counter-Discourse", Kunapipi 10:3 (1987), p. 18.

${ }^{39}$ Graham Huggan, "Is the (Gunter) Grass Greener On the Other Side? Oskar And Lucinda In the New World", World Literature Written in English 30:1 (1990), p. 9. ${ }^{40}$ Stead, Answering to the Language, p. 186.

${ }^{41}$ Stead, Answering to the Language, p. 186.

${ }^{42}$ Graham Huggan, "Is the (Gunter) Grass Greener on the Other Side? Oskar and Lucinda in the New World", p. 4.

${ }^{43}$ Anthony Hassall, Dancing on Hot Macadam: Peter Carey's Fiction (St. Lucia, Queensland: University of Queensland Press, 1994), p. 131.

${ }^{44}$ Lorna Sage, "Backwards into Destiny", Times Literary Supplement, April 1-7, 1988, p. 363.

${ }^{45}$ Ross Wynne-Jones, "Time To Publish", Independent on Sunday, 14 Sept., 1997, p.8. 


\section{Chapter Four \\ Post-modernism and IIistory}

1. Introduction: The End of the Metanarrative

2. Salman Rushdie, Midnight's Children and Literary Studies after Empire, 1981

3. A History of the World: Penelope Lively's Moon Tiger, 1987

4. Scholarship and Detective Work: A.S. Byatt's Possession: A Romance, 1990.

5. Magic Realism and African Cosmopolitanism: Ben Okri's The Famished Road, 1991

6. Cultural Fragmentations: Michael Ondaatje's The English Patient, 1992 7. Conclusion: Dismantling the Enlightenment

Introduction: The End of the Metanarrative

A group of diverse Booker Prize winning novels are linked by their post-modern narratives and exploration of post-modern society in the aftermath of empire. These novels explore empire's "edge", the borderlines between empire and "Other", the transition from modernity to post-modernity: geographical, racial, psychological limits, the liminal spaces and time zones in which territories are mapped, the boundaries of discourse established and dissolved, periods in which the narratives of history are deformed and reformed, and the dissolution of the binding force of empire.

The novels discussed here invoke worlds which are frequently fragmentary and chaotic. These novels resist attempts to assemble them into a single overarching category, they resist metanarratives. All are at a tangent to the historical narrative of empire, and self-reflexively they attempt to defuse the binary model of identity established between coloniser and colonised. They are novels which emphasise the subtlety of the novel as a 
form in which to explore and give voice to the diffusion of empire because of its ability to invent and fictionalise, as well as to represent reality. Their engagement is primarily in the aesthetic arena, with style and writerly qualities rather than in an appeal to underlying essences and core truths. They are novels which explore surfaces as much as analyse psychological depths. In the course of exploring the paradoxes and negotiations of identity as cultures and customs collide, they highlight a tension between illusion and reality, between order and chaos that is played out in modernist and post-modernist debate. They represent the eclipse of the single dominant Western view of history.

Midnight's Children, Moon Tiger, Possession, The Famished Road, and The English Patient are narratives that contest the idea of absolutes, of underlying truths and objective realities. There is a sense in all novels of a larger disorder breaking in on the stable worlds that are assumed by the novel's narrators, be this the imposition of an invading culture, changes in moral and intellectual climate, or war, mystery, or illness.

In 1994 Salman Rushdie, won the "Booker of Bookers" for Midnight's Children which celebrated the first twenty-five years of the Booker Prize. More perhaps than any other Booker Prize winner, Rushdie is an advocate for the kind of literary plurality or diasporic spread of Englishness or English language usage that the Prize has come to represent, albeit from an anglo-centric perspective. Rushdie's own viewpoint is always that of the liminal figure, a figure from the margins (he engages in both the irony and the marginalisation of the post-colonial and post-modern). In Midnight's Children Rushdie confines a notion of the inter-connectedness of the cultures of the First and Third Worlds. He explores the intermingling of racial, ethnic, and hybrid identities, but he never quite abandons the sense of the onlooker, frequently troubled and set-apart at a slight angle to the frenetic and hustling world that his narrator assumes as the novel's reality. Midnight's Children self-consciously attempts to describe an India whose stories are too numerous to be contained. The narrative is oriental, circular, never-ending, and Rushdie uses a parodic epic form to debunk myth because no myth, he suggests, is large enough to contain the teeming and multiple stories of India. 
The narrative of Possession spans the mid 1850s to the contemporary mid-1980s present. Byatt recreates, in largely letter and verse form, a simulacrum of a romantic PreRaphaelite past which she juxtaposes with the post-modern narrative present. Her overall aim in Possession is to explore the amorphousness of history, the way history and human relations are mediated and structured, the way romance and "possession" are engendered through language, and how the past is echoed in the present. Possession is metafictional; it is writing about writing and plunders the past in order to make sense of the present. The attempt to find the truth about Ash and the parallel love affairs of the novel's "fictional" protagonists signal the attempt to preserve myth and meaning in the complexity of the contemporary world, with it multiple narratives, noise and disorder.

Penelope Lively's Moon Tiger is yet another among the Booker Prize winning novels that explore the history of empire. From her death-bed, Claudia, the novel's aged and wealthy protagonist, idiosyncratically interprets the events that have comprised her privileged and adventurous life. Through Claudia Lively also explores the way in which Western concepts of history have changed with the transition from modern to postmodern worlds. Single, historical, diachronic linear narratives are abandoned for "kaleidoscopic" synchronic views-perspective from a single point in time. These are depicted as entwined in the events of Claudia's personal life and relationships, and they evolve as Claudia matures. Through Claudia, Lively explores Western notions of recording history from Darwinism to post-structuralism, from evolutionary theory to the Baudrillardian simulacrum. She questions whether there is still a point to history. Is Western history at the end of its development? Moon Tiger questions Western classification of the "Other" and subverts the authority of monolithic narrative at the same time as it argues for a kind of localised, personal authority.

Ben Okri won the Booker Prize in 1991 with his third novel, The Famished Road. He was then 31 and the youngest author to win the Prize. Okri is a Nigerian-born British resident. In his novels he writes predominantly about the changing consciousness of the colonial and post-colonial Nigeria of his birth, and in his short stories of the plight of the immigrant and the indigene within a cosmopolitan context. Like Rushdie, as a writer he 
is an "internationalist" evoking the literature of Britain and Africa in his approach to the novel form. His writing is characterised by a lyrical song-like quality of prose and imaginative flights of magic-realism that owe something to Rushdie and the South American novelist Gabriel Garcia Marquez. Okri's novel celebrates the voice from the margins and the congruence of indigenous renaissance with post-modern play.

Born in Sri Lanka, Canadian Michael Ondaatje is concerned in The English Patient with the fragmented lives and cultural disruptions that are a consequence of the Second World War. The enigmatic figure of the "English" patient is a metonym for the ambivalence which characterised the interaction of imperial culture and the culture of the colonised prior to the outbreak of war in Europe. Ondaatje is a cosmopolitan from the Third World and like Coetzee he describes the meeting between two or more worlds in his novel, positioning his patient's enigmatic identity as ironically "English" at the centre of this collision.

All these novels, then, acknowledge the interfusion and intertextuality of narrativesbe they literary, historical or mythical-in the aftermath of empire. They represent the many different energies that interact as empire spreads, consolidates, and dispands, and the hybrid and multiplex identities that it leaves in its wake. Running through each of these novels is the tension between a rejection of the order, depth and meaning afforded by the belief in truth and reason, which are the tenets of Enlightened modernism, and the embrace of newly articulated post-modern depthlessness and surficiality, together with the schizoid aesthetic and cultural identities in the period of global late-capitalism.

\section{Salman Rushdie, Midnight's Children, and Literary Studies after}

\section{Empire}

As Rushdie puts it in the introduction to his book of essays, Imaginary Homelands: "I've been in a minority group all my life - a member of an Indian Muslim family in Bombay, then a 'mohajir'-migrant-family in Pakistan, and now a British Asian."1 As far as Rushdie can be claimed to be a post-colonial author at all, he belongs on the post- 
modernist rather than anti-modernist side of the "post-colonial" divide. The antimodernist position is that of "cultural nationalism". It takes the form of nativism, or indigenism - those groups who see themselves as the victims of imperialism asserting the need to create a cultural identity uncontaminated by universalist or eurocentric concepts, seeking native origins or roots, and locating "authentic" cultural identity in the past. Antimodern post-colonialism involves the idea of seeking to recover precolonial and organic traditions unclouded by superimposed forms of colonial culture and distorting images of racism.

The post-modern post-colonial, by comparison, is characterised by the deconstruction, rather than reconstruction, of unitary identities. This involves neither a return to origins nor a fulfilment of histories and traditions interrupted by colonialism but rather sets about demonstrating that all cultural identity is essentially hybrid, historically contingent, and changing - not stable and homogenous, but multiple, fluid and contradictory. The postcolonial migrant embodies this position; he or she represents the borderline figure inbetween cultures-Homi Bhabha's sense of the liminal characterised by the transgression and translation of cultural differences. While this position does not entirely encompass Rushdie's work, he leans toward the post-modern and deconstructive rather than the antimodern, essentialist side of the post-imperial divide.

Rushdie's style - dense, cryptic, magic-realist, metafictional, metahistorical, is very close to his content. As Timothy Brennan puts it:

He has done what few writers in any tradition have done: recorded the totality of neo-colonialism as a world system, with its absurd combinations of satellite broadcasts and famine, popular uprisings and popularist rant, forced migrations and tourism. One might say he brings British literature up to date: For he occupies more than any other contemporary writer a special place at the crossroads of the English literary scene: the old 'Novel of Empire', which he transforms and which (as he points out) still exists as television special, film and 
travelogue for the popular magazines; 'Commonwealth' literature-that fictional entity created by scholars in the provinces and depending on the imaginary coherence of tea time, the Cambridge Overseas Examinations and the pound note; and the tradition of anti-colonial polemic, richly represented in England for over two centuries by foreign intellectuals more or less permanently based there. ${ }^{2}$

Rushdie celebrates a polyglot internationalism in which all influences and histories are open to the writer's imagination, and nothing may necessarily be excluded by the proclivities of birth or the politics of religious or secular hegemony. In the place of such exclusion Rushdie offers a devilish, playful and sometimes ascerbic satire of the politics of intolerance; frequently, as in The Satanic Verses, a sceptical Western perspective meets a fundamentalist Eastern one. Rushdie posits a culture of translation, a "stereoscopic" vision in which the Anglo-Indian writer, while having many possible manifestations, not least of which is that of "internationalist", is "borne-across" cultures: "I, too, am a translated man. I have been borne across," writes the narrator of Shame, and something is lost and something gained in translation. ${ }^{3}$ Nobody is any longer "one thing", the act of writing re-makes a language and with it necessarily involves the re-fashioning of cultures and identities. As Rushdie puts it: "To conquer the English may be to complete the process of making ourselves free."4

It is not merely the freedom of Indian or Pakistani independence to which Rushdie refers, nor the process of "reverse-colonialism" in which British immigrants are the articulators of contemporary British cultural consciousness. As a writer enamoured of the experience of life as a member of minority groups, Rushdie ultimately pursues artistic and political freedom, in both its social and cultural forms. He attempts to break free from the Manichean binarism between the coloniser and colonised that is at the centre of the colonial ideology and, using India as a model, in its place offers multiplicity as the defining characteristic of post-independence cultures. However, the political nature of Rushdie's use of the word "conquer" in the above citation is troubled. To conquer there 
must be a conquered, and hence a freedom won at the expense of another's loss. A perpetuation of this binarism, albeit in modified form, between coloniser and colonised is discernible in Rushdie's commentary on his own work and on the situation of the writer in the colonised world. The status of immigrant and naturalised Briton, however, makes it possible for Rushdie to plumb a multiplicity of commingled faiths, to write of and through a variety of literary sources and traditions, Eastern and Anglo-Western, and this sense of division and multiplicity ultimately defies any binarism.

There is a corresponding ambivalence in Rushdie's post-independence India in which the language of the coloniser becomes not a tool for subjugation but ironically one for an uneasy liberation. As Rushdie explains:

There is ... an interesting North-South divide in Indian attitudes to English. In the North, in the so-called 'Hindi belt', where the capital, Delhi, is located, it is possible to think of Hindi as a future national language; but in South India, which is at present suffering from the attempts of central government to impose this national language on it, the resentment of Hindi is far greater than English. After spending quite some time in South India, I've become convinced that English is an essential language in India, not only because of its technical vocabularies and the international communication which it makes possible, but also simply to permit two Indians to talk to each other in a tongue which neither party hates. 5

For Rushdie, literature is "self-validating"6; a book is not justified by the author's political "worthiness" to write it, but by virtue of the quality of what is written. Rushdie's pluralistic narrative method in Midnight's Children expresses the desire for the reader to become aware of the multiplicitous nature of life, to become above all more tolerant of difference: "'For God's sake, open the universe a little more!"'7 
India is home to the largest film industry on earth. The stereoscopic vision that Rushdie presents in Midnight's Children is an attempt to answer the questions: What is India? How can it be represented in a post-modern world aside from in the relationship of the coloniser and colonised? For Rushdie there is no one vision of post-independence India; in a view ironically not dissimilar to the colonial observations of Kipling and Forster, India cannot be contained by a single reading. As Saleem puts it in Midnight's Children: "there are many stories to tell, too many, such an excess of intertwined lives events miracles places rumours, so dense a commingling of the improbable and mundane! I have been a swallower of lives; and to know me, just one of me, you'll have to swallow the lot as well. Consumed multitudes are jostling and shoving inside of me ..." (9)

As Rushdie points out in Imaginary Homelands (1991) India is a continent the size of Europe. It contains the worlds largest "democracy" and is "home" to a sixth of the world's population, who nevertheless remain disunited by the lack of a common race, religion, or culture. The largest obstacle to a unified India is communalism, the religious hatred that is the expression of a basic, fundamental, and often bloody opposition between Muslim and Hindu religions.

In Midnight's Children Rushdie offers a vision of a post-independence generation, the "midnight's children" of the novel's title born in the hour of midnight on the Indian day of independence (August 15th, 1947), being themselves succeeded by a generation of Indian pragmatists. Rushdie's vision of a generation of Indian pragmatists succeeding that of "midnight's children" is essentially optimistic, and by Rushdie's own admission, increasingly unlikely to be bome out in reality: "'My' India has always been based on ideas of multiplicity, pluralism, hybridity: ideas to which the ideologies of the communalists are diametrically opposed. To my mind, the defining image of India is the crowd, and a crowd is by its nature superabundant, heterogeneous, many things at once. But the India of the communalists is none of these things." 8 The presence of the Raj is the unannounced shadow of the novel and Saleem and his alter-ego Shiva represent the 
nexus of ambivalence that belies the construction of a unitary identity in postindependence India.

In Midnight's Children the superabundant, polyglot, and heterogenous India becomes a metaphor for the multiplicity of influences, styles, conversations, and ideas of contemporary culture. In an increasingly post-modern world the centre has shifted from the axis of London to a prolificity of cultural centres. National or literary identities no longer need be written or read in binary fashion as counter to another or others: the notion of a centre and periphery defined in terms of nationhoods no longer holds. The literary debate concerning the dissolution of empire and the literatures which have emerged from its fragmentation is underdetermined in relation to the adherence to the binary paradigm of coloniser and colonised. The reluctance to abandon the centre-periphery debate in the context of Anglo-Indian fiction is compelled first by a nostalgia for the Raj, and secondly for semantic simplicity. There is a relationship between England and India but it is no longer characterised in centre-periphery terms which encourage binary thinking. As Adam Aziz comes to the realisation about the intersection of Western and Eastern medicine in Midnight's Children:

In the compartment the new Amina Sinai sat (in mint condition) with her feet on the green tin trunk which had been an inch too high to fit under the seat. With her sandals bearing down on the locked museum of her father's achievements she sped away into her new life, leaving Adam Aziz behind to dedicate himself to an attempt to fuse the skills of Western and hakimi medicine, an attempt which would gradually wear him down, convincing him that the hegemony of superstition, mumbo-jumbo and all things magical would never be broken in India, because the hakims refused to co-operate; and as he aged and the world became less real he began to doubt his own beliefs, so that by the time he saw the God in whom he had never been able to believe or disbelieve he was probably expecting to do so (66-67). 
In Midnight's Children authenticity is questioned by the swapping of the children, from different castes, at birth; this acts so as to reverse binary arguments, confusing forever the figures of good and evil with their opposites. The issue of re-appropriation Rushdie identifies as symptomatic of the English literature of cross-pollination. As Rushdie puts it: "What seems to me to be happening is that those people who were once colonised by the language are now rapidly remaking it, domesticating it, becoming more and more relaxed about the way they use it—assisted by the English language's enormous flexibility and size, they are carving out territories for themselves within its frontiers." 9

Here it is useful to emphasise the direction that Rushdie indicates when he says "they are carving out territories for themselves within its frontiers"--there is no necessary implication of a writing back to the centre-emphatically not a writing back to an "authentic" source of a hieratic English literature "proper". Rather, the suggestion is that of a consolidation within, and a radiating out from the frontiers of an English language belonging to no one centre. Rushdie is engaged in the literary exercise of bringing the Third World into the First and thereby changing both worlds in the process, but in some ways he is caught in this position of dubiety. The metaphor of fragmentation and multiplicity is enhanced through Rushdie's use of magic realism in Midnight's Children which allows him, as Mujeebuddin Syed puts it, freedom ". . . to move between the Modernist/postmodernist and folkloric traditions of India. Out of the dialects of this juxtaposition comes the peculiar, hybrid tale of India, incorporating a complex web of Hindu and Islamic (and even Christian) motifs, the philosophies of maya and karma and Sufism and interweaving private/personal and public/political histories of the Indian subcontinent." 10 Magic realism is thus a device Rushdie employs (through Saleem) to explore the multiplicity of representations of India and to defy Western expectations of closure in a self-consuming narrative fraught with ruptures, with the double-codedness of the liminal: "Consumed multitudes are jostling and shoving inside me; and guided only by the memory of a large white bedsheet with a roughly circular hole some seven inches in diameter cut into the centre, clutching at the dream of that holey, mutilated square of linen, which is my talisman, my open-sesame, I must commence the business of 
remaking my life from the point at which it really began, some thirty-two years before anything as obvious, as present, as my clock-ridden, crime-stained birth" (9-10).

Midnight's Children offers a departure, then, from the binary configurations latent in the cultural analyses pioneered by such works as Edward Said's Orientalism. In Orientalism Said advances a model of imperial hegemony characterised by a Western intellectual tradition which firstly created its own versions of oriental cultures and subsequently imposed these on Oriental peoples in act of denigration. A tautologous hegemony was thus established in which the West justified its own domination of the Orient through a "false" reading of Oriental culture, which it then sought to "civilise" by an act of cultural subjugation. However, as Anthony Cohen points out, this kind of analysis of dominated cultures is open to examination "because it confuses the form of indigenous response with its substance."11

What Cohen seems to have in mind is that although the indigenous response might be perceived as a form of cultural retreat, in substance it was not. In Midnight's Children this is borne out in the opening section where the intrusive narrator comments briefly on the influence of Gandhi in India 1919: "Leaflet newspaper mosque and wall are crying: Hartal! Which is to say, literally speaking, a day of mourning, of stillness, of silence. But this is India in the heyday of the Mahatma, when even language obeys the instructions of Gandhiji, and the word has acquired, under his influence, new resonances ... because Gandhi has decreed that the whole of India shall, on that day, come to a halt. To mourn, in peace, the continuing presence of the British" (33). However, with Indian independence three decades away, historically what is conceived as an indigenous retreat in the face of the colonial programme was turned around into an assertive stance by the late 1960s and the indigenous "badge" (what Cohen calls the "putative stigma of cultural inferiority") worn as a kind of valediction, an inverted symbol of superiority.

Rushdie does not, however, merely supplant the era of Indian independence within a wider, post-modern notion of global pluralism. For Rushdie, the Indian continent already contains such a pluralism: far from being subsumed by it, India itself is still subsuming; pluralism is an Indian metaphor. Rushdie is stringently opposed to this 
subtle form of cultural amnesia in overcoming not so much a history of displacement, as one of the determination to exert control over destiny.

India does not require a legitimating mode, but for Rushdie the annunciation of this sloughing off is the "chutnification of history" (459). It is the particular nature of Indian society that it marks a resistance to the binary configurations that dominate Western thought. The relationship between the coloniser and the colonised is not expressed in terms of a static demarcation between imperial discourse and disempowered culture, but in terms of transformation. As Sara Suleri puts it:

.. . if colonial studies is to avoid a binarism that could cause it to atrophy in its own apprehension of difference, it needs to locate an idiom for alterity that can circumnavigate the more monolithic interpretations of cultural empowerment that tend to dominate current discourse. To study the rhetoric of the British Raj in both its colonial and postcolonial manifestations is therefore to attempt to break down the incipient schizophrenia of a critical discourse that seeks to represent domination and subordination as though the two were mutually exclusive terms. Rather than examine a binary rigidity between those terms-which is an inherently Eurocentric strategy-this critical field would be better served if it sought to break down the fixity of the dividing lines between domination and subordination, and if it further questioned the psychic disempowerment signified by colonial encounter. For to interpret the configurations of colonialism in the idiom of such ineluctable divisions is to deny the impact of narrative on a productive disordering of binary dichotomies. ${ }^{12}$

For Rushdie, contemporary India is born with the magically empowered children of the novel's title on the day of Indian independence: August 15, 1947. The opposition asserted as between coloniser and colonised, which Suleri's discourse seeks to 
deconstruct and elaborate, has shifted from within India itself to the wider picture of India as a nation already arrived, perhaps for the first time, as a cohesive national identity within the First World consciousness, newly articulate, and jostling with multivocal identities. Rushdie is simultaneously claiming a place for his nation of origin firmly within the literature of the First World, and informing his audience of their own misconception of the processes of history and the aftermath of empire and imperial relations with the Indian East. His novel differs from the Raj novels in so far as his vision of an Indian internationalism and multiculturalism is embraces the politics of pluralism, whereas the Raj novels are more particular in the exploration of a British India.

\section{A History of the World: Penelope Lively's Moon Tiger}

Penelope Lively's 1987 Booker Prize winning Moon Tiger is a novel which enmeshes stories within stories. Moon Tiger attempts a "history of the world", in broad sweep a history of twentieth-century Western civilisation and the world of its dying protagonist, popular historian Claudia Hampton. Like Rites of Passage, Lively's novel explores the limits of the representational possibilities of language and acknowledges that all historical narratives are in some ways related. Her novel is a historiographic metafiction. It is fiction that explores the nature of fiction and attempts to decentre the dominant linear view of history.

Claudia is dying from stomach cancer. Reviewing her life as variously successful journalist, author, historian, and mother, she attempts to write her own history, "The history of the world as selected by Claudia: fact and fiction, myth and evidence, images and documents." 13 The major structural theme is apparent from the beginning: the displacement of linear narrative with the "kaleidoscopic" diachronic narratives of the postmodern. Lively's is a metafictional novel which comments on changes in the contemporary post-war British novel in which the decline of modernism and the ascension of the post-modern, the death of the author characterising the end of history, is 
played out against the themes of Claudia's life. The narrative of Moon Tiger, like Claudia's view of history, is asynchronous:

The pack of cards I carry around is forever shuffled and re-shuffled; there is no sequence, everything happens at once . . . . We all look differently at it. My Victorians are not your Victorians. My seventeenth century is not yours. The voice of John Aubrey, of Darwin, of whoever you like, speaks in one tone to me, in another to you. The signals of my own past come from the received past. The lives of others slot into my own life: I, me, Claudia H (2).

Moon Tiger, then, is a novel that entwines histories of various kinds: Claudia's history, her personal narrative of her family, those of her family; metafictionally, the history of storytelling and the history of the evolution of consciousness that in itself tells the story of changing perception of the nature of history, subjectivity and representational qualities of language. As Deborah Raschke suggests: "Hampton's 'history of the world', really her own story with scattered vestiges of historical antiquity; most obviously is an interfusion of the subjective and objective, of public and private. Her story is a melding of polyphonic voices, each with its own history to tell."14

On her death-bed (the death bed of the author-narrator) Claudia reviews her life and the themes of her life as they entwine with those of others, through world events and across continents. As Claudia does so, Lively re-examines the notion of authorship, the place of history in discourse and the body of a "British" fiction. Moon Tiger has a pervasive Englishness which updates and comments on the tradition of the novel of British regionalism and colonial fiction exemplified by D.H. Lawrence, Graham Greene, Rudyard Kipling, and E. M. Forster. Lively evokes a British sense of imperial dissolution but re-positions this theme within a cosmopolitan post-modernism.

Moon Tiger celebrates language, the accumulation and unfolding of knowledge and understanding through language: "The power of language. Preserving the ephemeral: 
giving form to the dreams, permanence to sparks of sunlight" (9). Lively also affirms the various narratives waiting to be told once the master-narratives of language and power are broken up. Again, as Raschke puts it:

Moon Tiger, like many postmodern texts, in querying historiography, decentres the definitive historical story, allowing repressed narratives that are no less definitive to surface. Taking historical narrative as one of its primary subjects, Moon Tiger suggests that history, ultimately elusive, is nonobjective and irreparably entwined with the personal, more contiguous than linear . . . Moon Tiger suggests that reconceiving the historical narrative demands a reconceiving of what constitutes fictional narrative and that this reconstruction, in turn, challenges the representations (particularly of women) that have been the product of these narratives. ${ }^{15}$

The asynchronous "history" of the narrative begins with brother and sister hunting for ammonites in coastal England in echo of Darwin, Lyell, Gosse and Charles in John Fowles' The French Lieutenant's Woman-as Claudia relates, "[m]y Victorians are not your Victorians" (2). Thus, framed by the death-bed of Claudia, Lively's novel invokes Claudia's beginnings with the universal beginning, the "primordial soup" of the origins of human beings. According to this kaleidoscopic history, the Palaeolithic is one remove from the nineteenth century - an epoch of scientific revelation eclipsing religious conventions. The notion of history and mythology are entwined in Claudia's personal narrative. Claudia fails her conventional school history exams.

The principal protagonists of the novel - Claudia, her brother Gordon, Claudia's lover Jasper, and her daughter Lisa-are respectively expatriate cosmopolitan colonial and post-colonial intellectual British, a mixture of English gentry and Russian Aristocracy, post-modern capitalist, and (ironically) regionalist and conservative English. By the time the conventional and middle-class Claudia and Gordon are at university Claudia's mother 
is described as "well into her retirement from history" (20). Claudia divides the players of history into two kinds: the front-liners like herself, her brother (who becomes a renowned academic economist), and her lover Jasper (diplomat turned media businessman), "those who find themselves thus placed whether they like it or not and those who seek involvement"; and those like her mother who are "just sitting it out." (21).

The lives of Claudia and Gordon, close childhood rivals, are entwined from the start, and there is more than a suggestion of incest in their early relationship. Sylvia, Gordon's wife, is both admiring of and condescending towards her husband's success in the world of academe. In his "mis-marriage" as Claudia regards it to his wife, Sylvia, a woman of conventional middle-class expectations, there is a hint of rivalry and disparagement. While Gordon's intellectual energy is prodigious, his emotional energy is minimal; he has a "laziness of the soul", (24) only in "hindsight are we wise about cause and effect" (28). In the place of modernist history, Moon Tiger advances a postmodern notion of "New History". As Pauline Rosenau explains: "New History makes no claim to special truth; it erases the difference between history and fiction ... and holds that there is as much to be learned about life from the one as from the other." 16

From the outset, Claudia's subjectivity confines her with its personal knowledge and prejudices, and as she relates her story she is self-consciously aware that she too remains ignorant. Claudia's self-consciousness about the telling of her own story allows Lively to explore the problematics of narration of history and subjectivity and the relation between the two. As Raschke points out:

History conventionally has been a linear story, has manifested a drive for closure and control-it has meant getting the story and the facts straight. In Lacanian terms, it is a privileging of metaphor (pleasure in directness, completion) over metonymy (pleasure in association, process, individual moments). Claudia's method privileges the latter-a state of embeddedness that constantly defers meaning and closure. ${ }^{17}$ 
As Claudia's cast assembles and as the plot develops, she, Gordon and Sylvia visit the Plymouth Plantation, a re-creation of the Pilgrim Village in 1627 of the eastern seaboard of America. Although the Plymouth plantation is an historical re-creation of a colonial pilgrim village of the $1700 \mathrm{~s}$, it is paradoxically a "static" copy of something amorphous; while its actors act out the part of pilgrim settlers, they re-create the plot for which there is no original text, only a pastiche of ideas from early colonial settlement. Claudia's response is to interrogate the "actors" with the ironic perspective of hindsight. By reconstructing the past as if it were the living truth, history is dominated by a single interactive narrative:

\footnotetext{
"You're spoiling the story, says Gordon. Perhaps there's an alternative story, says Claudia ... Destiny, says Claudia, overrated, to my mind. I don't imagine you're giving it a thought, right now? Well . . . says the Irishman. Exactly, Claudia continues, any more than I am. It's only later that people start preaching about destiny" (36-37).
}

The simulated historical village is a post-modern re-creation of history that in confining history to a single bounded narrative (albeit an interactive and intertextual one) nevertheless contains a residual modernism against which Claudia rebels. Claudia does not, willingly, like Gordon, enter into and sustain the plot of the simulated village. Rather she uses her knowledge of history in the present to change the rules and alter the script when addressing the actors who cannot leave their prescribed roles in the simulation; she talks about a future (known in the present) but unknown to them in their simulated past. As such, Claudia resists the notion of a single prescribed story, suggesting that there may be many alternatives. "History" oppresses Claudia; modernity is no longer seen as an epoch of liberation but one of stiflement. Claudia seeks to resist the "closure" imposed on her life and the themes within it by measurements, judgements, and objective recording outside phenomenological experience. In Moon Tiger Claudia 
represents the author's frustrations with the limitations of the modern conception of history. Although Lively's narrative is structured around the familiar kind of flashback chronology of the modernists, Claudia's ruminations on history and her mocking attitudes towards her brother Gordon, express frustrations with the conventional English historical novel and introduce post-modern ideas within an otherwise conventional and stable linear plot.

Moon Tiger, despite its post-modern intimations, remains a readerly novel or a "lisible" text. As Pauline Rosenau points out, a modern text is written with the intention of communicating a specific, precise message. It assumes a passive reader who merely takes the message, rather than a post-modern writerly or "scriptible" one, like, for example, Italo Calvino's If on a Winter's Night (1981), which is a post-modern text that is written to be rewritten by the reader with every reading. This open text invites interpretation and re-interpretation. The reader's role is that of production, construction. Lively's concern is that notions of history and the telling of stories are changing. She relates this within a conventional modern narrative which contains post-modern ideas of the death of the author and subject, the end of history, new history, pastiche and simulacrum, intertextuality and metafiction. ${ }^{18}$

Claudia's post-modern rhetoric does not always, however, embody the qualities that she espouses. If she constructs the world through language she is also the product of it. Her thinking remains a remnant of empire in so far as her naming of empire's "Others" is caught within a modernist narrative, from which she increasingly distances herself, but which her "society" has constructed. She remains Western, privileged, contradictorily populist and elitist, the child of First World late capitalism: "And all the while the inhabitants of this world are among us, like aborigines, like Minoans, people from elsewhere safe in their own time-capsule" (43). The irony is that the time capsule is not safe from the rupture of either colonisation (breaking in on its own theory of history and notion of time), nor is it contained by a modernist interpretation from the further hegemony of Western thinking now distancing itself from that movement and code. The myth of primitivism or the "time capsule" denies the coevalness of cultures. 
Moon Tiger is a novel of post-empire in that it encompasses both colonial and postcolonial worlds from the viewpoint of a questioning and intelligent, but privileged, narrator. "'I'm writing a history of the world'", Claudia begins, "[t]he whole triumphant murderous unstoppable chute-from the mud to the stars, universal and particular, your story and mine" (1). The novel entwines history and Claudia's narrative from the point of view of her own overriding "eclectic" viewpoint. Claudia's experiences are of preand post-war Britain, wartime and post-colonial Egypt, industrial and post-industrial Europe, and a post-modern United States. Her experiences of pre-war Britain are those of a child raised on late Victorian and early modern classics and agnosticism. Moon Tiger portrays an essentially entropic world in which the turn of the earth is mirrored by the burn of Claudia's insect coil. Her allegory at the edge of empire is evident in her desire to understand and appropriate the discourse of history in order to construct her own life and world view, and to contain that of others. For Claudia this becomes an autotelic act-having or being a purpose in itself. Moon Tiger is in part an emotional voyage of re-discovery and in part an allegory of the rhetoric of a diminishing empire in a changing and post-modern world.

\section{Scholarship and Detective Work: A.S. Byatt's Possession: A Romance}

A.S. Byatt won the Booker Prize in 1990 for her metafictional academic and literary detective novel, Possession: A Romance. Possession participates in the genre of British historiographic metafiction. Possession is also related to the sub-genre of academic fiction, often humorous, characterised in the 1970s and 1980s by the novels of David Lodge and Malcolm Bradbury, and earlier by those of Kingsley Amis. The narrative of Possession spans roughly a hundred and thirty years from the mid-1850s to the mid1980s present. Byatt re-creates, inletter and verse form, a simulacrum of a romantic PreRaphaelite past which she juxtaposes with the narrative present. Possession explores the amorphousness of history, the way romance and "possession" are engendered through language and how the past recapitulates into the present. As Giuliana Giobbi puts it, 
Byatt's Possession is an ". . . interweaving of the personal quest for identity with a literary (detective-like) search and elements of romance." 19

Roland Michell, a frustrated scholar of Victorian poetry working in the "Ash Factory", which operates from the British Museum, discovers a letter penned by his research interest, famed (and fictitious) Victorian poet Randolph Ash, in an old volume hitherto confined to the safe of the Reading Room of the London Library. The letter, which he comes across by accident, intimates a relationship with an-at this point-unknown female correspondent, the fact of which would throw a new and original light on the much trammelled and academically precious industry of "Ash scholarship".

Roland, with the help of Maud Bailey, a scholar of feminist poetry and distant relative of Christabel LaMotte, whom the two soon establish to be the subject of Ash's hitherto unknown romantic connection, sets about forging the link between the two Victorian poets, one step ahead of the rivalling and competitive trans-Atlantic "Ash industry". The "Ash industry" is spearheaded by a number of well drawn-academic characters: Roland's cantankerous supervisor and British Ash expert, Professor Blackadder; American Ash "scholar", Mortimer Cropper, trustee of the wealthy Newsome Foundation in Albuquerque, which partially funds Blackadder's "Ash factory"; and Professor Leonora Stern from Tallahassee, author of "Motif and Matrix in the Poems of LaMotte", who introduces a sensual feminism and discussion of female creativity into the rapidly forming Ash milieu. What begins as an academic detective story quickly develops into a complex novel of emotional discovery and historical amorphousness, as the present is recapitulated into the Romantic Pre-Raphaelite past, and events of the past are "uncovered" and patterns repeated in the present.

Possession is metafictional; it is about academic and emotional possession, about the layering of history, the nature of writing and scholarship, authenticity, and private and public lives. The romances of the novel-Christabel's affair with the married Ash, and Maud's with the already partnered Roland-are played out against a Pre-Raphaelite canvas of Victorian and contemporary consciousness. More than this, however, the 
novel concerns itself with the romance of authorship, and the complex relationship of authors to their work.

Possession demonstrates that the concerns of the Victorian era are also uncannily similar to the concerns of the post-modern present: "Maybe we're symptomatic of whole flocks of exhausted scholars and theorists. 20 Not only is the past in the novel mirrored in the present, but the conception of a Victorian consciousness is mirrored in the conception of post-modernity. Byatt is concerned with feminism, biography, truth, and originality. Her novel combines mystery, comedy, and romance within a self-reflexive post-modern narrative.

As the novel progresses an equality of male and female narrative sensibility is established in the polarity of the two Victorian poets, interwoven with the theoretical concerns of present-day literary criticism. Byatt refuses to be concerned only with writing for women on the principle that it does a disservice to elevate female authors as women rather than writers because it prevents their works from being judged on merit. As Olga Kenyon puts it: "Byatt considers the refusal to be bound by sexual identity releases creative energy in herself as a writer." 21 This becomes a sub-theme of Possession in which Christabel, for many years thought (in the manner of Sir George) to be an inferior poet in comparison with male poets like Ash, enjoys in the present critical climate the re-readings of a feminist critical attention. The feminists critics are ironically inclined to read her work as a lesbian text, however, and the discovery of her affair with Ash would certainly suggest that a revision of the work is needed.

Byatt demonstrates how the themes of the past are echoed in those of the present. For Byatt there is not so much a male and female literature as a general literature, and she does not ignore or privilege the one sex for the sake of the other. This concern with the levelling of gender binaries as well as with the amorphousness of history in terms of the Victorian past and the contemporary present has been the theme of many of her novels including The Virgin in The Garden (1978) and Still Life (1985). As Kenyon observes: 
. . B Byatt, together with Murdoch and Lessing, refuses to be pushed into being a spokeswoman; like George Eliot, she is more interested in the origins of knowledge, the functioning of our brains, mental imagery and perception. Eliot felt free to incorporate ideas she discussed with Lewes after they had attended lectures on science and philosophy. Byatt feels free to quote ideas of Darwin, Einstein and Foucault when they illuminate her own thoughts... if the novel represents our view of the world more than any other genre now, as many critics, from Lodge down to myself contend, then it is acceptable that Byatt includes scientific and cultural ideas which have transformed our thought. For her the novel is explicitly—not just implicitly—what Barthes defined as 'text': 'a multidimensional space in which a variety of writings, none of them original, blend and clash' (54-55).

Roland Barthes's post-modern idea of a text as multidimensional space in which a plurality of writings, none of which are "original", interfuse and interact, echoes Elliot L. Gilbert's sense of Pre-Raphaelite concern with belatedness and innovation, a midVictorian cultural climate characterised by the anxiety of a historical overdetermination. In Possession, however, Byatt modifies the view of historical belatedness into one of historical amorphousness. She allows for originality despite the post-modern climate of the pastiche, bricolage, and simulacra, and does so through Roland's growing appreciation for originality in the experience of verse. Such subjective originality creates in the reader the impression that the lines are already known, that they carry an import of transcendental "truth". Thus in many ways in her later novel Byatt replies to Kenyon's reading of her earlier works.

Just as the Pre-Raphaelites sought originality in the portrayal of the mythological and "natural" female at a subversive level beneath the patriarchal dominance of the Victorian era, Byatt allows for an originality sown in Roland's awakening poetical sensibility by the emotive vigour of Ash's verse. Both her key protagonists in Possession are 
eventually liberated, Roland from the claustrophobia and frustration of Blackadder's scholarly patriarchy, and Maud by literally and metaphorically letting her Pre-Raphaelite hair down and throwing off a destructive and Freudian impasse with the sexually aggressive Fergus Wolf in favour of a relationship of empathy with Roland.

The sense of a "feeding on" and "living through" the vitality of the past is for Maud and Roland a peculiarly post-modern feeling. It is a sense of the present which is defined in terms of pastiche and of a multiplicity of pasts, a pastiche or bricolage of many styles and historical borrowings which are re-assembled in the present. This feeling is heightened when the couple visit "Bethany", the three-storeyed house in Richmond that Christabel had lived in before her affair with Ash. The house has been renovated, and is now preserved in a state of "originality" that it would not have enjoyed in Victorian times:

'It's a good restoration job,' said Maud. 'It makes you feel funny. A simulacrum.'

'Like a fibre-glass copy of the sphinx.'

. . . 'It would have been sootier. It would have looked older. When it was younger.'

'A postmodern quotation-' (210-211)

Byatt's novel thus invokes the mixed genres of university fiction, historical detective story, and post-modern historiographic metafiction. Byatt is writing from the tradition of the British Victorian women novelists, and with a concern for Anglo-Western and eurocentric notions of literature and literary tradition, which she infuses with an interest in contemporary literary theory. Britain, and a sense of Anglo-Saxon and Celtic revivalism, are very much at the centre of her novel, its layers of history being tightly interwoven in the fabric of an Anglo-Western literary consciousness.

If the Pre-Raphaelite movement created an image of women and nature which men could in turn control, then the form of "romance" that Christabel here advocates allows women to create their own image in their own terms, suggestive of a medium of 
expression in which women might not be controlled by the construction of the male gaze. For both Ash and LaMotte, Roland and Maud, "romance" is more than just a physical complicity: it is a meeting of both the emotions and the "rational" mind, a mutual regard in which neither sex is advantaged at the expense of the other. However, in the Victorian romance, Christabel is the victim, the one who suffers. She carries Ash's child abroad, presumably both to avoid scandal and to give the child a chance for a natural development. Ash retains his marriage to Ellen, and the two do not correspond for many years, having decided that this is how it must be after they part in Yorkshire. While she is willingly complicit in this social arrangement, the meeting of the minds is brought out only in letters-"not in this world" but the "romance land" of the poetical verse to which Sabine refers. Maud, however, intimated by the Freudian dominance of the somewhat narcissistic and predatory Fergus Wolf, has the chance of very real social equality with Roland in the novel's contemporary present. Thus, Byatt emphasises also the disparity between fictional worlds and the social worlds of the different eras.

Possession is fundamentally a critique of post-modem culture which in dialectical fashion participates in the culture which it at least in part attempts to parody. The surficiality in the post-modern era is questioned by Byatt within the context of "romance":

Coherence and closure are deep human desires that are presently unfashionable. But they are always both frightening and enchantingly desirable. 'Falling in love', characteristically, combs the appearances of the world, and of the particular lover's history, out of a random tangle into a coherent plot. Roland was troubled by the idea that the opposite might be true. Finding themselves in a plot, they might suppose it appropriate to behave as though it were a sort of plot. And that would be to compromise some kind of integrity they had set out with . . . They were children of a time and culture which mistrusted love, 'in love', romantic love, romance in toto, and which nevertheless in 
revenge proliferated sexual language, linguistic sexuality, analysis, dissection, deconstruction, exposure (422-423).

Like the Victorians one hundred and thirty years earlier, they become saturated with knowledge, technique, theory (the past in the present), to the extent that "genuine" emotional response, original expression becomes caught in a proliferating web of connections. This "saturation" becomes a form of overdetermination or "possession". The ultimate ironic expression of "possession" in the novel is played out by Ash in correspondence with Ellen. All the social signals and constraints are read in the Victorian male's favour. Christabel is prevented from sharing a life with the already married Ash, and Ellen from a relationship of genuine love with her husband, and this because of their adherence to the social mores of the day, despite their knowledge of Ash's infidelity, and the "illicit" relationship with the female poet. Maud and Roland unravel the cover-up between Ash and Christabel and later, Ash and Ellen. Ironically, however, this brings the present-day couple closer together. This cover-up is pieced together both through letters and by a close textual reading of the clues of their poetry. Ultimately, what possesses all Byatt's protagonists are the social constructions and moral constraints of the era.

This "possession" is repeated in the contemporary present, socially and within the scholarship that draws the protagonists together. The final letter that would prove the relationship and would necessitate rewriting and reinterpretation by the Ash industry is contained in a box known to be buried with Christabel. Cropper raids the grave, and the others, who by now have joined forces, assemble to stop him. In a moment of characteristic irony they speculate on the consequences of their discovery to the interpretation of the poetry of the two Victorian lovers: "No use of the word 'ash' may be presumed to be innocent" (485).

The ending is suitably "romantic", with Roland receiving job offers and he and Maud becoming romantically entwined. "Possession" is finally exorcised by the two, for Maud the sexual possession implicit in her previous relationships with men is diffused, but for 
both there is a sense of the original awoken anew, re-born with the truth discovered in the unearthing of the past: "In the morning, the whole world had a strange new smell. It was the smell of the aftermath, a green smell, a smell of shredded leaves and oozing resin, of crushed wood and splashed sap, a tart smell, which bore some relation to the smell of bitten apples. It was the smell of death and destruction and it smelled fresh and lively and hopeful" (507).

In Possession, then, Byatt deals with a genre of metafictional literary detective story in which the past, both constructed and real, is recapitulated in the present. The narrative is multilayered and complex, interweaving letters, poems and journal entries. The major theme in the novel, however, is possession - the way in which language and literature possess, take hold of, or construct the lives of the protagonists both past and present. Possession can take a variety of forms: spiritual, economic, literary, psychological, sexual, legal, and is manifested in different ways in each of the major characters. Byatt explores the power of language through the amorphousness of history. Like John Fowles and Peter Ackroyd, she fuses British literary tradition with twentieth-century narratological experimentation and in so doing articulates a very Anglo-Saxon literary revival, metaphorically breathing life back into the history of poetry and ideas from which her sense of tradition is derived. Like The Old Devils, Paddy Clarke Ha Ha Ha, and How Late It Was, How Late, Possession focuses on refashioning historical ideas and events and in so doing examines the ambiguous nature of authenticity in a contemporary climate that is indexed to the depthless and undisciplined representation of the past.

\section{Magic Realism and African Cosmopolitanism: Ben Okri's The}

\section{Famished Road}

"A dream can be the highest point of a life."

Ben Okri, The Famished Road ${ }^{22}$ 
Okri has written five novels (to 1996): Flowers and Shadows (1980), The Famished Road, and a sequelThe Songs of Enchantment (1993), Astonishing The Gods (1995), Dangerous Love (1996); two books of shortstories: Incidents at the Shrine (1986) and Stars of the New Curfew (1988), and a book of essays, A Way of Being Free (1997). He wrote his first novel at the age of nineteen, while a student living in London. His style has undergone remarkable shifts, from the realism of the "coming of age story" of Flowers and Shadows, to the more adventurous "phenomenological" realism (and quasimagic-realism) of the stories of Incidents at the Shrine and Stars of the New Curfew, to the magic-realism of The Famished Road, and again to the somewhat more pointed and controlled magic-realism of The Songs of Enchantment.

Taking the magic-realist cue from Rushdie, Okri's Azaro is one of the spirit children of The Famished Road, a lyrical epic which hovers in a hinterland between poetry and prose. The Famished Road has very little in the way of traditional plot. It concerns the fortunes of an impoverished Nigerian family forging an existence in a post-colonial Africa racked with internal change, civil war, and political tyranny. The Famished Road owes more to classical epic-toThe Odyssey or The Aeneid-or medieval romance than it does, for example, to the tradition of the post-colonial novels of V.S. Naipaul or the counter-discourse of Chinua Achebe or Wole Soyinka, while its lyricism carries echoes of the poetry of Derek Walcott or the poetic prose of Wilson Harris. Mimetic themes are present, but the text is one ultimately of imaginative flight-signifying a kind of reconciliation of the African imagination with a Western context.

Okri's narrative suggests a procreative realm that displaces the familiar world of the "Western" text. However, there is lineage of literary form that precedes The Famished Road traceable in African writing through Amos Tutuola's The Palm-Wine Drinkard (1952) and My Life In The Bush of Ghosts (1954), and Soyinka's Ake, the Years of Childhood (1981), while also borrowing from the magic-realist writing of Rushdie and Gabriel Garcia Marquez. What is "new" in the literary form of The Famished Road is the way in which the sustained fantasy acts so as to displace and subvert, in return, the traditional English realism. In The Famished Road and the sequel, Songs of 
Enchantment, the familiar realist form seems at once unstable, antiquated, and impoverished. In much the same way that the bone people (1983) invents an epic medieval romance form for Maori mythology, The Famished Road creates a Nigerian mythology that extends in Western literary and African mythical terms elements of a literary stylistic tradition intimated in previous Nigerian literature, but now within a First World context.

In the writing of Okri, Rushdie, and Marquez, surrealism is replaced with a magicrealism that alters traditional parameters of literary reality. In Okri's fiction magic-realism is strengthened by the association with an African spirit world. Hunger and palm-wine become the ingredients of a magical and metaphysical voyage that comments on the experience of changes in perception in time and reality that follow from the forces of colonisation and modernity.

In Magical Realism and the Fantastic: Resolved Versus Unresolved Autonomy (1985), Amaryll Chanady isolates three main components of magic realism, distinguishing it from surrealism, fantasy and the "uncanny". The first component is that of the juxtaposition of two conflicting but autonomously coherent narrative perspectives: the enlightened and rational view of reality, and the acceptance of the supernatural as part of everyday occurrence. A disparity is thus engendered between what we know the author knows to be real and what he or she wills into being; between the implicit recognition of a world governed by logic, and the ostensibly irrational world made explicit in the text. Where this differs from the merely fantastical, the interpolation of the supernatural in a realistic setting, is that for the magic realist the supernatural is not problematic, nor is it highlighted in the manner of a textual difference. As she puts it: "[a]lthough the educated reader considers the rational and irrational as conflicting world views, he does not react to the supernatural in the text as if it were antinomous with respect to our conventional view of reality, since it is integrated within the norms of perception of the narrator and the characters in the fictitious world." 23 The result may be a dissonance or "hesitation" that disconcerts the reader but it is presented as matter of fact. 
Chanady's second criterion is that of the resolution of logical antinomy in the descriptions of events and situations in the text. It is an act of derealisation which invokes in the text not a juxtaposition of the fantastical (a world completely dissimilar from our own) with the reality of a conventional everyday view, but rather the conception of a literary domain which totally displaces our conventional view of reality between the poles of the ultra-rational and the supernatural. It thus differs from the "uncanny" in so far as the latter is concerned with the creation of an "atmosphere" in the text and this may merely be that of the "strange".

The third criterion is an authorial reticence, an absence of censure or surprise. Judgements about the veracity of events or the authenticity of the world view are not made. Such an absence ensures that no hierarchy is formed within the text concerning the validity of the world it depicts. This is essential for the presentation and maintenance of a world view that is radically different from, although equally valid to, that of conventional "reality". This is the world inhabited by Azaro, a world which both knows the Western view of reality in its own terms, and what are perceived by the West as the "supernatural" worlds of the spiritual "Other". Okri juxtaposes the two so that the reader does not privilege one over another. The Famished Road on one level suggests a flight from national hunger into the possibilities of the imagination. If a cohesive national identity defeats the politics of a nation racked by civil unrest then it is to be negotiated in the realm of the imagination, a magic-realism that portents a very "real" alternative to the "reality" it displaces.

The Famished Road is an allegory of a nation's re-birth, a state of perpetual coming into being, a fate co-eval with that of the "spirit children"--the equivalent of the "midnight's children" of Rushdie's novel:

The happier we were, the closer was our birth. As we approached another incarnation we made pacts that we would return to the spirit world at the first opportunity. We made these vows in fields of intense flowers and in the sweet-tasting moonlight of that world. Those of us 
who made such vows were known among the Living as abiku, spiritchildren. Not all people recognised us. We were the ones who kept coming and going, unwilling to come to terms with life. We had the ability to will our deaths. . . Each new birth was agony for us too, each shock of the raw world. Our cyclical rebellion made us resented by other spirits and ancestors. Disliked in the spirit world and branded amongst the Living, our unwillingness to stay affected kinds of balances ... To be born is to come into the world weighed down with strange gifts of the soul, with enigmas and an inextinguishable sense of exile. So it was with me (5).

The Famished Road enacts a battle between good and evil. Azaro and the spirit children represent charm and good luck and the Masquerade represents demonic force. The characters of the novel battle for possession of their "true" identities both in the magically-real world and the spirit world which extends and deepens the semantic layering of the text. Azaro is instructed by his idealistic, impoverished, and physically and implicitly spiritually powerful father in a way to conduct his life: "This is what you must be like. Grow wherever life puts you down" (38). Magic-realist events and happenings are interpreted ambiguously by Azaro's father: "'A snake came out of its roots and bit her.' 'That's good. Life is full of riddles that only the dead can answer,' was Dad's reply" (40). In many ways Azaro is a charmed tabula rasa on which the history of post-colonial Nigeria is written; he represents the possibilities of a dignified national re-birth.

The social centre of the village community is Madame Koto's bar and she is the prosperous matriarch of their lives. Azaro spends much time with her and she rewards him with food and drink, believing his presence brings the bar good luck: "When the women came by they always teased me... I learned a lot about what was happening in the country through them. I learned about the talk of Independence, about how white men treated us, about political parties and tribal divisions" (76). 
Famine is a constant threat to the community and hunger is the overriding motif of the novel. Azaro and his family are in a state of subsistence living; often they go without food and are arrears in the rent of their small and broken-down rooms. However, hunger is also a source of dignity, feeding the imagination where the body remains unsatisfied. When Azaro has to go without an evening meal his mother replaces his food by the promise of a story which satiates his imaginative appetite and recapitulates the spiritual and mythological theme of asceticism. Azaro's mother tells him the story of the cricket and then that of the stomach in which the theme of hunger, both physical and spiritual, is entwined with the magic-realist form in an allegory of colonial contact, juxtaposing Western rationalism with African mythology from the perspective of an African narration.

Okri is an international author, who in his magic-realist allegories of a colonial and post-colonial West Africa generalises the forces of destruction and redemption that influence all races and cultures. His is a dream of transcendence: the possibility of negotiating a way to live in a world which embraces both Western rationalism and African mythologism; that blends African mythmaking with contemporary cosmopolitanism. Okri writes of the transition from local myth to internationalism, from tribal memory to modemism. His novel places a fulcrum between pre-colonial and postcolonial worlds, offering a vision that looks forward (and backwards) to the multiculturalism of contemporary Britain and to the potential of hybrid cultural forms and freedoms offered in the era after empire. As he puts it in The Famished Road: "A dream can be the highest point of a life" (500).

\section{Cultural Fragmentations: Michael Ondaatje's The English Patient}

Experimentation with the genres of film, music, and photography are as much a shaping influence on Ondaatje's oeuvre as are his obvious interests in the dialogues of history, politics, and literary theory. These characteristics are revealing of two major forces at play throughout his work: a concern for the constraints of theory, textuality, and design that works towards capturing the elusiveness of phenomenological experience in the 
written word, juxtaposed with an inverse desire to release the representative word from the page, to reach beyond language to the psychological transformations of metaphor and perception affected by language. This dynamism is in turn coupled with a desire to isolate and transcend theoretical constraints, a desire for the reconstruction of new and exotic cultural mythologies from the energies released from the deconstruction of the old. The exploration of cultural fragmentations and dislocated lives is a pervasive feature of Ondaatje's The English Patient, a lyrical re-honing and re-housing of the disruptions precipitated in the Second World War, and it articulates a tension between discovery, sudden knowledge and loss: "[a]11 these fragments of memory . . . so we can retreat from the grand story and stumble accidentally upon a luxury, one of those underground pools where we can sit still. Those moments, those few pages in a book we go back and forth over." 24

In The Archeology of Knowledge Michael Foucault writes the "frontiers of a book are never clear-cut . . . it is caught up in a system of references to other books, other texts, other sentences: it is a node within a network . . . [a] network of references." 25 The frontiers of Michael Ondaatje's The English Patient are less than clear cut and the novel contains numerous references to other books including the author's own. However, the 1yricism of The English Patient makes it a universal celebration of all lyrical fiction and this quality links the novel to others just as profoundly as the intertextuality of the networked text. This then is the basic concern of The English Patient: theoretical discourse is undermined by story, and post-structural fragmentation by the celebration of the lyrical. The structure of the novel is established by a series of juxtaposed and intermeshed conjunctions of opposites which revolve in luminescent combinations, reversals, and paradoxes. Ondaatje's characters are portrayed as being perpetually between places and homelands, they are map-makers who have exchanged codes, and who are locked in political bonds and geographies which they seek to inhabit and evade.

Like Rushdie's The Satanic Verses (1988), The English Patient opens at its near beginning with an image of a man falling, burning, from the sky. Like Rushdie's novel, in which his two protagonists plummet out of an exploding aircraft, The English Patient 
is concerned with the intersection of East and West, and the revision and replication of histories of old among among the blurring truths and shifting identities and allegiances that are the characteristics of modernity's wake. The enigmatic figure of the English patient recovering from massive burns in the bombed and dilapidated Villa San Girolamo at the dusk of the Second World War; the figures of the Canadian nurse Hana who tends to him, refusing to leave, of Caravaggio, the morphine thief, and of Kip, a Sikh from the British Sapper Unit, can be construed as symbolic either of a Europe fragmented and damaged by war, or of the post-war text with its fragmentations, ruptures, and narrative voids.

The intertextuality of The English Patient is elaborate and extensive. The setting of a fragmented Europe and the suggestion of new orders supplementing old is introduced with a description of the ruined villa and Hana reading from a notebook that the patient brought with him through the fire which all but consumed him. The book is a copy of The Histories by Herodotus, the "Father of History" and the "Father of Lies", to which the English patient has added, carrying it with him for years, cutting and glueing pages from other books or writing in his own observations "so they are cradled within the text of Herodotus" (16). As Stephen Scobie has pointed out, the English patient's amended copy of The Histories thus functions in Derrida's sense of the "supplement" which stands in paradoxical relationship with the original. As Scobie observes: "For the English patient, Herodotus's The Histories is both complete (the act of cutting and pasting in pages from other books foregrounds itself as the addition of something extraneous) and incomplete (what he writes into the text responds to a lack, and a demand, that the text already exhibits). In thus supplementing the text of Herodotus, the English patient is duplicating the supplementary nature of the original. . ."26

More than this, however, the English patient is amending history, abridging it, fusing the old with the new, collapsing facts within fictions, camouflaging fictions within fictions. Identities and paradoxes give way to a trompe l'oeil of surficiality and iconography. As the English patient, Almasy, rewrites history, altering its boundaries, exposing subjectivities like mines, Kip defuses bombs as he would read and deconstruct 
a complicated text. Masks and guises are assumed, discarded; roles are swapped, self becomes "Other" and "Other" becomes "self".

The intertextual narrative unfolds with the English patient being read to at random from the books in the library of the villa, twenty of which the nurse had earlier nailed together to rebuild a step destroyed by fire when the villa was attacked by mortar. Books are thus objects, artefacts as well as histories; they can be used physically to fill gaps as well as to represent them as fragmented narratives within the text of The English Patient: "[s]o the books for the Englishman, as he listened intently or not, had gaps of plot like sections of a road washed out by storms, missing incidents as if locusts had consumed a section of tapestry, as if plaster loosened from the bombing had fallen away from the mural at night" (7). History and fiction are thus blurred from the outset, intertextual narrative is given flesh in the form of a working journal, the imagined and the experienced are entwined: "[w]as this invented? Dreamed by him while wrapped in oil and felt and darkness?" (22).

The intertextuality of The English Patient involves not only references to The Histories, The Last of the Mohicans, John Milton, Christopher Smart, Anne Wilkinson, geographical descriptions of the desert and technical descriptions of bomb disposal, but also Ondaatje's previous novels. The characters of Hana and Caravaggio are borrowed from In The Skin of a Lion whose timeframe stops in 1938. Hana, we learn, comes from Canada and her father's name is Patrick, as was that of Hana's father in In The Skin of a Lion. Caravaggio, the thief of In the Skin of a Lion, is also the thief of The English Patient who joins Hana at the villa because of his connection with her past, his concern for her, and his former friendship with her now dead father. Only the character of the patient himself, and the Sikh sapper Kip, who joins them at the ruined villa are in this sense "new" to Ondaatje's writing, while the patient perhaps has his conceptual origins in the tannery of In the Skin of a Lion, the father-figure who gets burned in the galvanizing processes. 27

The English patient's first "lesson" takes place while Hana reads to him from Kim, which, as Hana observes, is inverted in the narrative present with the English patient as 
wise elder, and Kip, the Indian Sikh, as young student. The English patient remonstrates with Hana the need to read Kipling slowly, "Your eye is too quick and North American. Think about the speed of his pen" (94). Hana is thus encouraged to read in the context of the written, to attend to the language as the writer would have. The patient advises an anthropological approach, entering into the text as an anthropological field worker moves into an area of study.

Ondaatje's metafictional approach sets up a dialect between a holistic viewing of culture as an originating force in language and the depthless interfaces of the postmodern. His novel persuades us in the direction of the elusive, phantasmic "writerly" text, the text that engages the author in the pleasure of writing. The novel is "written" as the reader attends to it, reinvented as the reader rereads. Through intextuality, saturated lyricism, and at one point the use of primitive drawing, Ondaatje blurs the boundaries between the production and consumption of the text. As Barthes puts it in $S / Z$ :

Our literature is characterised by the pitiless divorce which the literary institution maintains between the producer of the text and its user, between its owner and its customer, between its author and its reader. The reader is thereby plunged into a kind of idleness-he is intransitive; he is, in short, serious: instead of functioning himself, instead of gaining access to the magic of the signifier, to the pleasure of the writing, he is left with no more than the poor freedom either to accept or reject the text : reading is nothing more than a referendum. Opposite the writerly text, then, is its countervalue, its negative, reactive value: what can be read, but not written: the readerly. ${ }^{28}$

The English Patient is also a love story - a love story of Hana for her "despairing saint" who "reposes like the sculpture of the dead knight in Ravenna" (96); a love story of the English patient for Katharine Clifton who died and was entombed in the desert; and a kind of love story about Hana and Kip, the living casualties of war and those who must 
bear the burden of transformation into the postwar era. The English Patient is also, however, a metaphysical love story, the romantic element entwined with a spiritual searching, a journey into the heart. It offers a kind of conflagration of history, self, and society, and simultaneously reaffirms the author in the text-Hana leaves The Histories, walks away from the open book lying on a table: "A love story is not about those who lose their heart but about those who find that the sullen inhabitant who, when it is stumbled upon, means the body can fool no one, can fool nothing-not the wisdom of sleep or the habit of social graces. It is a consuming of oneself and the past" (97).

Kip sleeps outside the villa in a tent but it is he who also remains in touch with the outside world via a crystal wireless set; it is he who assumes an English father in the figure of his mentor "Lord Suffolk", and follows his codes like a dutiful son. In this way he too is an "English" patient. It is he who hears of the final cruelty of the West upon the East with the dropping of the atom bomb near the novel's end: "the shadow of humans suddenly in the air. This tremor of Western wisdom" (284). Caravaggio however, is the one who becomes most concerned with the identity of the English patient. He represents the desire to reveal the faces behind the masks, the quest for truths about people that is echoed from the "searcher" of In the Skin of a Lion: "He needs to know who this Englishman from the desert is, and reveal him for Hana's sake. Or perhaps invent a skin for him, the way tannic acid camouflages a burned man's rawness" (117).

This desire for truth is a product of the confusion of war, the confusions of an ailing Europe, the suggestion that knowledge is not to be found merely in giving things a name, demarcating them, or destroying them; un-naming them: "But here they were shedding skins. They could imitate nothing but what they were. There was no defence but to look for the truth in others" (117). Words are taken off pages into lives, and lives are distilled into words, set down on pages. Text and reader thus interact, fiction becomes reality and reality, fiction.

Hana and Kip go their separate ways. She remains alone, ideal and idealistic, the one whose "wild love leaves out luck" (301), the nurse to the despairing saints of history, 
the one who the writer does not know enough to take under his wing and who is not yet fully realised in Ondaatje's novel, but who nevertheless represents the possibilities for future fictions. The English Patient is concerned with the blurring of boundaries: geographic, phenomenological, textual, and generic. It is compelled by the twin desire for containment and release: by a language of demarcation and erasure, of ownership and loss: "We are communal histories, communal books. We are not owned or monogamous in our taste or experience. All I desired was to walk upon such an earth that had no maps" (261).

The English Patient entwines theory, history, mythologies; the representation of the crumbling of one world order, one era, and the acknowledge of a paradigm shift into the next. The novel explores "cultural aporias" between desert, Europe, and the nationalisms of post-colonial nation-states as Ondaatje argues for the re-centring of the author in history and text. As Geetha Ganapathy-Dore Sahib puts it, "Just as the novel of the hyphenated, translated postnational man mirrors his fractured time and fragmented self, his language accommodates an integrated vision of both the Western and other modes of representation and becomes a trompe l'oeil form of expression. The ambivalence of the white man with a black skin and the black man with a white sensibility depicted in The English Patient bears witness to this. "29 The rhizomal textuality and characterisation, the accentuation of the lisible as opposed to the scriptible, the novel's simultaneous intertextuality and pastiche (re-honed and re-explained through an all-pervading and timeless lyricism) serve so as to breathe life back into the husk of the novel burnt by the hegemonies, classifications, and methodological solipsisms of a fragmented and depthless post-modern world.

The English Patient, like Midnight's Children, offers to revise the scope of the novel in English. Ondaatje's notion of the translated, post-national person belonging to no one nation or race, the "Englishman", Almasy, who may not in fact be English but Hungarian, finds a corollary with Rushdie's sense of being borne-across cultures as part of a hybrid and interdependent diasporic global flux. Perhaps, in passing, the novel evokes something of the nostalgia, but not the domesticity, of the Raj novels. In 
depicting a central character of uncertain but supposedly English origins the novel deliberately plays with the mystique that surrounds the character of the English, the British Empire, and the English reading community that the language evokes. This mystique evolved with documentation of the upper- and middle-classes experiences abroad and involved a rigorous control of the discourse and representation of early colonial interactions, subsequent anthropology, ethnography and travel writing against which a generic "character" of the English and empire emerged.

\section{Conclusion: Dismantling the Enlightenment}

Among the Booker Prize winning novels are those novels that grapple with the issues of post-modernism, with the way in which the "grand narratives" of Western history-and in particular of enlightened modernity-have broken down. Midnight's Children, Moon Tiger, Possession, The Famished Road and The English Patient are irreverent towards absolutes-especially the idea of "centre", be this geographical or of self and truthalthough self-reflexively and with irony they work towards reinforcing the ideas they critique. It is not so much that there is no truth-much as John Berger's G seeks to evade political reality - but that the truth is no longer wanted; instrumental modes of universal reason, and holistic patterns of meaning are damaging and erode differences, defy individuality and imply an order which is seldom present.

Metanarratives such as "history", "politics", and "science" which harbour legitimate foundations for truth are no longer fashionable. With the post-modern the aesthetic is foregrounded in different ways and the modernist notion of depth gives way to the interplay of surfaces, to surficiality. This is especially noticeable in Ondaatje's The English Patient with its lyricism and intertextuality. Post-modernism aims to demonstrate the inadequacy of the Enlightenment theories of knowledge which argue for an objectivity that post-modernists see as inaccessible. Claudia's recounting of her personal history in Moon Tiger blurs her role as objective historian. For post-modernists, meaning is radically indeterminate: all texts are implicated in one another through an endless 
intertextuality - there is no space outside of text, no original source of meaning. That knowledge is a reflection of truth, and that we can discover a stable foundation for it in God, history or reason is a principle of foundationalism that post-modernists defy. In The Famished Road hunger and palm-wine become the ingredients for flights into alternative realities for Azaro and his family, flights into magic away from the encroachment of the roads and city. History, rather than a continuous and stable reality, is a plurality of alternative discourses. The Enlightenment goals of reason, progress, knowledge and emancipation are de-valued, mocked, and rejected. The Enlightenment preoccupation with the objective view-the view from nowhere-is also dispensed with.

In each of the novels discussed in this chapter, history is shown as pastiche, as composed of many alternative narratives. There is a sense of meaning derived fleetingly out of chaos only to dissolve, and of the past breaking into the present to assert a claim to authenticity which is now redundant. Revelation replaces the certainty of uncovered truth. For example, the experience of knowledge as explanation rather than the instrumentalist's reliance on prediction lies behind the character's experience of the mystery surrounding the poet, Ash, in A.S. Byatt's Possession.

For many, post-modernism is the latest version of long-standing attempt to address social and political issues through an aestheticised understanding of the world, a world that is constantly changing, fragmentary and contingent. Knowledge can never be absolute because the object of knowledge is expanded by the attempt to know it. Knowledge of the world cannot be divorced from meaning in the world and neither the concept of self nor world can be foundationally conceptualised. Post-modernism embraces contradictions and expresses antipathy to certain kinds of order. Midnight's Children is a novel of teeming and multiple events and ideas which defy a sense of general organising structures. Presence is endlessly deconstructed to disclose an elusive absence. There is movement in these novel from a modernist sense of depth to a postmodern sense of surface, from harmony and stasis to a more kinetic sense of interaction, from high seriousness to play. Modernist nostalgia for origins is dismissed. Postmodernists have viewed literature as a permanent religious revolution that transforms the 
secular crowd into a sacred community, one in which laws of imagination and science are equal. For post-modernism, as for the all the novels discussed in this chapter, the laws of myth and science are partial codifications of reality-ways in which the mind imitates itself. As such they express a form of entropy as this self-imitation becomes entrenched, an entropy that is also discernible in another form in a group of insular British novels which have won the Booker Prize and which are disussed in the following chapter.

\section{Notes}

${ }^{1}$ Salman Rushdie, Imaginary Homelands: Essays and Criticism (London: Granta/Viking, 1991), p. 4.

${ }^{2}$ Timothy Brennan, Salman Rushdie and The Third World (London: Macmillan, 1989), p. xiii.

${ }^{3}$ Salman Rushdie, Shame (London: Jonathan Cape, 1983), p. 12.

${ }^{4}$ Rushdie, Imaginary Homelands, p. 29.

${ }^{5}$ Rushdie, Imaginary Homelands, p. 17.

${ }^{6}$ Rushdie, Imaginary Homelands, pp. 64-65.

${ }^{7}$ Rushdie, Midnight's Children (London: Picador, 1982), p. 21. All further quotations from this work are taken from this edition and are followed by the relevant page number in parenthesis.

${ }^{8}$ Rushdie, Imaginary Homelands, p. 14.

${ }^{9}$ Rushdie, Imaginary Homelands, p. 21.

${ }^{10}$ Mujeebuddin Syed, "Midnight's Children and Its Indian Con-texts", Journal of Commonwealth Literature 29:2 (1994), p. 97.

${ }^{11}$ Anthony P. Cohen, "Culture as Identity: An Anthropologist's View", New Literary History 24:1 (1993), p. 3.

${ }^{12}$ Sara Suleri, The Rhetoric of English India (Chicago: University of Chicago Press, 1992), p. 4. 
${ }^{13}$ Penelope Lively, Moon Tiger (London: Penguin, 1987), p. 51. All further quotations from this work are taken from this edition and are followed by the relevant page number in parenthesis.

14Deborah Raschke, "Penelope Lively's Moon Tiger: Re-envisioning a History of the World", Ariel 26:4 (1995), p. 116.

${ }^{15}$ Raschke, "Penelope Lively's Moon Tiger", p. 117.

16Pauline Rosenau, Post-Modernism and the Social Sciences: Insights, Inroads, and Intrusions (Princeton: Princeton University Press, 1992), p. 67.

${ }^{17}$ Raschke, "Penelope Lively's Moon Tiger", p. 124

${ }^{18}$ Rosenau, Post-Modernism and the Social Sciences, p. xiv.

${ }^{19}$ Giuliana Giobbi, "Know the Past: Know Thyself. Literary Pursuits and Quest for Identity in A.S. Byatt's Possession and in F. Duranti's Effetti Personali", Journal of European Studies xxiv (1994), p. 41.

${ }^{20}$ A.S. Byatt, Possession. A Romance (London: Vintage, 1991), p. 267. All further quotations from this work are taken from this edition and are followed by the relevant page number in parenthesis.

21Olga Kenyon, "Fusing Tradition with Twentieth-Century Experimentation", Women Novelists Today. A Survey of English Writing in the Seventies and Eighties (Brighton; Harvester Press, 1988), p. 52. All further quotations from this work are taken from this edition and are followed by the relevant page number in parenthesis.

${ }^{22}$ Ben Okri, The Famished Road (London: Vintage, 1991), p. 500. All further quotations from this work are taken from this edition and are followed by the relevant page number in parenthesis.

${ }^{23}$ Amil Chandy, Magical Realism and The Fantastic: Resolved Versus Unresolved Autonomy (New York: Garland, 1985), p. 23

${ }^{24}$ Michael Ondaatje, The English Patient (London: Picador, 1988), p. 148. All further quotations from this work are taken from this edition and are followed by the relevant page number in parenthesis. 
${ }^{25}$ Michael Foucault, Archeology of Knowledge, trans., A. M. Sheridan Smith (London: Tavistock, 1972), p. 23.

${ }^{26}$ Stephen Scobie, "The Reading Lesson: Michael Ondaatje and the Patients of Desire", Essays on Canadian Writing 53 (1994), p. 100. Scobie is discussing Derrida's sense of "supplementarity" in Of Grammatology, trans. Gayatri Chakravorty Spivak (Baltimore: Johns Hopkins University Press, 1976), p. 304.

${ }^{27}$ Michael Ondaatje, In The Skin of a Lion (London: Picador, 1988), p. 143.

${ }^{28}$ Roland Barthes, $S / Z$, trans., R. Miller, pref., Richard Howard (New York: Hill \& Wang, 1974), p. 4.

${ }^{29}$ Geetha Gunapathy-Dore, "The Novel of the Nowhere Man: Michael Ondaatje's The English Patient ", Commonwealth Essays and Studies 16:2 (1993), p. 100. 


\section{Chapter Five \\ "Englishness" and "Domestic" Lives}

1. Insularities: The Inwardness of Post-Imperial Britain

2. Empire's Others: Bernice Rubens' The Elected Member, 1970

3. Taking a Break: Stanley Middleton's Holiday, 1974

4. Nature or Nurture: David Storey's Saville, 1976

5. Curtain Call: Iris Murdoch's The Sea, The Sea, 1977

6. Empire's Twilight: Kazuo Ishiguro's The Remains of the Day, 1989

7. Conclusion: "Englishness" and "Domestic" Lives

\section{Insularities: The Inwardness of Post-Imperial Britain}

Among the Booker Prize winners are novels which reflect a sense of entropy or centrelessness, a tiredness at the former centre of empire. Those Booker Prize winners which reflect this inwardness include Bernice Rubens' The Elected Member, Stanley Middleton's Holiday, David Storey's Saville, Iris Murdoch's The Sea, The Sea, and Kazuo Ishiguro's The Remains of the Day. If an idea of England emerges from these novels it is of one of insularity, timidity, and domesticity - an echo of the former empire in its expansive phases, an England marginalised by its own anticipation of the sense of "others" - other races, customs, religions-now comprising the "British". These novels are characterised by a pressure from the past manifest in a rich sense of social history, a tendency towards nostalgia, the difficulty of imagining a future out of the memory-laden present, and a sense of conundrum and listlessness.

Bernice Ruben's The Elected Member turns its attention to the plight of Jews and the large Jewish immigrant population in Britain. It portrays a British immigrant Jewish family and the struggle of the parents to instil Jewish tradition in their children who are brought up within a different culture from their parents. The novel reflects the inarticulate beginnings of British multiculturalism and the tension between the status of new 
immigrants and the established culture in the post-imperial Britain of the $1950 \mathrm{~s}$ and 1960s. Ruben's novel describes the recalcitrance and insularity of this family in midtwentieth century urban England.

The Elected Member also focuses on neuroticism and the harmful emotional pressures that can be brought together within families as cultures collide. The main protagonist, a successful barrister, Norman Zweck, has been rendered delusional by the expectations of his socially pretentious family and the tightly interwoven Jewish community. The Elected Member is the story of the fragmentation of an immigrant Jewish family under the moral oppression of an overly dominant but now deceased mother and the yoke of the religious guilt imposed by an overly strict adherence to the Jewish faith. The Elected Member participates in the wider theme of the entropy of empire from within the immigrant Jewish community of the Zwecks.

Stanley Middleton's Holiday shared the Booker Prize with Gordimer's The Conservationist in 1974. Holiday is a novel of domestic manners, describing the disintegration and eventual reaffirmation of the marriage of its educated middle-class ordinary English protagonists. Set on the British coast largely at a seaside resort, the novel has an air of nostalgia for domestic coastal grandeur and a narrow scope that quietly confirms its unassuming domestic literary concerns. The novel describes a sense of middle-class Englishness that remains seemingly unaffected by the rapid changes that British culture is ungoing as a result of the loss of empire. Meg and Edwin are middleclass bourgeois protagonists and Middleton's novel quietly questions the social strata that is the foundation of perceived British hegemony, the unassuming basis of eurocentrism. In depicting the insularity of the post-war middle-classes Holiday is domestic Britain at its most cliched and the Booker Prize panel at its most unadventurous and unselfcritical.

Storey's Saville is a novel which, from the point of view of its sensitive, increasingly educated working-class protagonist, examines the veil of pretence and false appearances that surround the South Yorkshire community of Saxton. The novel describes the breakdown of the old class system and reflects the displacement within Britain of a socially mobile in-between class. Storey portrays the working-class "victims" of a 
general depression from within the imperial system, whose children having "benefited" from the educational privileges of empire are now more equipped to see the injustices of the society which shaped them. Not only is empire challenged from without but, as Saville shows, it is challenged from within by an increasingly embittered meritocratic working-class who see the injustices of the system without the rhetorical and almost selfdefeating reactionary and fatalistic rhetoric of their forebears. The frustrations experienced by this displaced generation are symptomatic of the claustrophobic nature of their working-class life. Educated out of one class, they do not share the emotional register of the next. The result is a sense of displacement and frustration.

The theme of entropy and empire is continued, again in a domestic vein, in Murdoch's insular and brooding novel of obsession, The Sea, The Sea. Although not so much concerned with the class system, Murdoch explores the personal angst of her middleclass protagonist, the retired playwright and stage director Charles Arrowby, who, in retreating to what he imagines is a serene withdrawal from the world in a remote seaside house to write his memoirs, invokes in his insular world a distorted play of the very egotism which he has sought to abandon. From the outset of his chronicle his consciousness is interrupted by a distorted vision from his unconscious, which fractures the stable world of Murdoch's novel. Charles's retreat mirrors the retreat of empire; his recalcitrance reflects British middle-class angst at the collapse of empire. Threatened by this interruption to his "normal" life, he must re-write his memoirs to attempt to account for the disruption. A seething British coastline plays anthropomorphic backdrop to Charles's own mental seascape. The Sea, The Sea represents the sophistry of an educated middle-class fragmented, and in Charles Arrowby an insular, solipsistic, and egotistical mind turned in on itself at retreat in coastal Britain.

Entropy and empire is the central theme of Kazuo Ishiguro's The Remains of the Day. Set during the summer of 1956, Ishiguro's text recounts the story of Stevens, an ageing butler at the grand English country house of Darlington Hall. Stevens has spent a lifetime in dedication to the profession of service to the late Lord Darlington. Prompted by his new American employer, Stevens embarks on a six-day motoring trip to the West 
Country. Stevens's travels are disturbed by memories of his long years of service in Darlington Hall and the anticipated visit to his lost love, the ex-housekeeper of the hall, Mrs Kenton. Ishiguro's text is at once a comedy of manners, a nostalgic story of lost causes, a study of personality, and a gentle but devastating analysis of the British class system and aspects of its culture. It offers a reflection of the decline of aristocracy and the "seat" of empire. The Remains of the Day offers a window onto the life of an anachronistic Butler who is the remnant of an anachronistic social system that is the very epitome of an "Englishness" now displaced in the diaspora of British cosmopolitanism. The Remains of the Day examines the role of "surveillance", the privilege of looking which excludes the onlooker from the reality that comprises the object of observation. Stevens' dedication to ideas of professionalism increasingly masks his personal reality and is at the expense of his private life. Thus, the novel comments ironically on the solipsism and decline of "Britishness" in the era of imperial dissolution. Written by a Japanese immigrant to Britain the novel provides a neat example of writing from Britain's multicultural milieu since the 1960s.

\section{Empire's Others: Bernice Rubens' The Elected Member}

Bernice Rubens won the Booker Prize in 1970 for The Elected Member. This, the second Booker Prize winner, is the story of the fragmentation of an immigrant Jewish family under the moral oppression of an overly dominant mother and the yoke of the religious guilt imposed by an overly strict adherence to the Jewish faith. The novel describes Jewish immigrant experiences in cosmopolitan Britain of the 1960s. The plot unwinds around the character of Norman who although precocious as a child and later a successful Barrister, has a mental breakdown and "goes mad" under the pressure of the expectations generated of him in his close-knit family life.

The story begins with Norman's neuroses, his hallucinations of silver-fish in his room, his obsessive-compulsive desire for cleanliness, and the drug habit that both feeds and sustains it. Employing an hallucenogenic social-realism reminiscent of Kafka and 
Burroughs, The Elected Member interweaves Norman's "rationalised" insanity and the effect it has on the members of his family: his father, Rabbi Zweck; his sister, Bella; and his married and ostracised sister, Esther. The narrative present is interfused with recollections of Norman's breakdown and the events and family history which led inexorably to it. Now a drug addict, Norman is hospitalised in a psychiatric institution in which he is supposedly to be weaned off the pills that he has been taking. There, however, he meets the "Minister" who can supply him with as many "whites" as he needs, and the parallel between the "underground" society of the hospital patients, evocative of Ken Kesey's One Flew Over the Cuckoos Nest (1962), and the relationships in the supposedly normal society outside (to which his family belongs) further dislocates Norman's already damaged consciousness. The two worlds are entirely unalike. This however, remains a sub-theme within the overall concern with the fragmentation of a Jewish family due to a precious and neurotic regard for their own separateness and an over-heightened sense of social pretension within a larger society that fosters that pretension. The Zwecks are doubly-isolated-both as individuals within the family and within the community at large.

Born in Cardiff in 1920 into an orthodox Jewish family, Rubens is the daughter of a Russian refugee. She has written at least seventeen novels and has worked as a filmmaker on features and documentaries for the United Nations. Rubens draws heavily on her Orthodox Jewish and immigrant origins in her writings, which reflect an intuitive awareness of the culture and religion whose mores she has inherited. Like those of her North American counterparts, Ruben's early novels are bleak dark-humoured depictions of Jewish characters, focusing on loneliness, misunderstanding, and failure.

The title of the novel suggests the overriding theme-that of the "scapegoat" of the Jewish family, the "elected member". Duty and family responsibility are invoked in a pattern of familial denial. Norman's madness, in large part "constructed" by the pressures of his family, is a reflexive condition of their anxiety in the wider community at large. The skull-caps of Jewry are interspersed with the white coats of mental health officers within Rabbi Zwecks's recollections of his immigrant beginnings in England. Revery is 
inspired by the rediscovery of his papers of naturalisation as the Rabbi searches through drawers after Norman's hospitalisation, looking for drugs, or the "clues to his son's murderer":

He was pleased with his own find. It had nothing to do with Norman. It was part of his own life, and safely nostalgic to investigate. He tried to order his memory so that it would recall the beginning of his story. Surrounded as he was by the chaos of neglected continuity, he wanted desperately to get one thing straight, himself and his beginnings in England, long before Sarah, God bless her, his wife, and Norman, God bless him, his son. He wanted to shed himself of his married and paternal years, of the birth of his children and Sarah's passing. He wanted to peel off circumstance, to whittle himself down to the short legged stubborn pinpoint that would answer to the name of Abraham Zweck. ${ }^{1}$

As Minister, Zweck clings to religion, locating his "essence" in faith: "He retrieved the prayer book, kissing it, and stood up and looked around him. Yes, that was all he had. That was all he was, his body and his means of function" (49).

The problem of ethnic status in a cosmopolitan England is not one that Zweck faces alone, however. $\mathrm{He}$ is part of a vast immigrant community with similar experiences. $\mathrm{He}$ recalls advice from a Jewish father, his wife's shopkeeper, on his initial arrival in England to forget the Rabbonischkeit and to establish a small business. Englishness and traditional Jewishness are assimilated into an uneasy hybridity. The gulf between cultures is established through the problems of translation:

They talked. Abraham's town, his family, their problems. It was a familiar story. They were all the same, the stadtels in the East, and now in the West too, bred from the same root. The shopkeeper's Yiddish 
was fluent, but it was punctuated by the occasional English word, which, by the gist of the general meaning, Abraham Zweck was able to understand. In his first years in England, this was the way he was able to pick up the language, collecting all these odd English throw-outs, for which the speakers knew no Yiddish equivalent. Words like wardrobe, electric fire, conservative. Hundreds of single words that together gave Abraham Zweck a great vocabulary, but little language. His conversation became like his friends', only in reverse. He would use Yiddish throwouts in the brackets of his halting English. The people of the neighbourhood understood him as he did them, and they learnt more Yiddish from his speech. It was a mutual linguaphone (51).

A "mutual linguaphone" it may be, but the process of assimilation for the Jewish Zweck and his immigrant family is one of unease, frustration, and a form of cultural "stutter". Unable to relinquish his inherent Jewishness, Zweck is consigned to playing out Jewish cultural stereotypes within a society which, while partially assimilating them, cannot reciprocate. The result is a partial embedding of Jewish culture within increasingly multicultural Britain and is manifest in Jewish insularity, doubt, frustration, and a recognition of "Otherness" which cannot be entirely reconciled. However, British literary society in general was resistant to multiculturalism, and remained preoccupied with the past. Zweck becomes both Minister and shopkeeper, teaching his children and those of the local community. The exception to this is Esther, who has married "outside", "opted out of her responsibilities", and been ostracised by the father. The process of assimilation is checked and ultimately denied in his children's experience by Zweck himself, and the overly dominant wife and mother to whose memory he remains committed: "'Ach.' He moaned, folding the naturalisation certificate into its original creases. He hadn't come very far since his arrival almost half a century ago . . . The Hebrew class was now only a trickle of children, and who knew who and where they would marry?" (52) 
Thus, as Shirley Kossick points out, Rubens' characters "themselves are too submerged in their own emotions to discover anything amusing in their predicament." 2 Norman, Esther, Bella, and Rabbi Zweck are not shallow people, but they are people bound to their own twisted sense of responsibility, faith, neuroticism and, in Norman's case, insanity. Norman's madness and drug addiction is in many ways caused by the high expectations imposed on him by his family, expectations which he cannot hope to sustain, and which were promulgated by his deceased mother and perpetuated by the family in a relationship of denial, selfishness and recrimination. The lives of the various family members were forced into unauthenticity by the pretensions of social and religious convention to which they adhered and the codes of denial and guilt assumed in their transgression.

Rubens' novel-like the short-stories of Ben Okri which are concerned with immigrant experiences in the Western metropolis, the Caribbean novels of George Lamming or even V.S. Naipaul's novels of disillusioned reverse-colonialism-paints a picture of insularity, loneliness and loss. None of the protagonists of The Elected Member achieves either integration or any degree of satisfactory assimilation within the dominant culture, least of all Norman who is emblematic of their disintegration. Insular, they occupy a community as xenophobic in its way as their perception of the larger society. Rubens's characters adhere to a sense of Jewishness that not only prevents them from establishing an identity within their adopted culture but actually serves to reinforce a self-induced opposition, the loneliness of entrenched isolation. Zweck is reluctant to abandon any sense of Jewishness, either in faith or behaviour or custom. He will concede little to his adopted culture and can only despair when his children transcend his aspirations for them embodied in his Jewish ethic. Although a Minister, and upon retirement a shopkeeper with his wife Sarah until her death, he will not look at his successes, only wallow in his failures and it is this kind of neurotic attention to an inevitable "doom" which ensures that he does fail, and his family with him in so far as they adhere to the image of themselves he and the domineering and histrionic motherfigure, Sarah, have constructed for them. 
The Elected Member is in the vein of social drama and black comedy. It concerns the disintegration of immigrant family life and relationships, social conscience and troubled consciousness. Rubens, perhaps to the novel's detriment, does not wander from these themes to speculate more widely on the nature of the immigrant experience itself. This, the second Booker Prize winning novel, does, however, confine an essential Jewishness that has both an archetypical and tragi-comic aspect. Rubens' novel is a fusion of many elements: thematically, the reverse colonialism and cosmopolitanism of V.S. Naipaul and Ben Okri, stylistically the maze-like world of Franz Kafka, the desperate-comic rebellion of Ken Kesey, the Jewish humour of Philip Roth (and Woody Allen), and the conventional contemporary English novel of morality in the manner of Anita Brookner or perhaps Penelope Lively, interwoven through all of which is Rubens' caustic humour and sense of Jewish distinctiveness. Rubens' novel demonstrates that post-imperial England is an uneasy melting pot in the post-war period, harbouring conflicting peoples and faiths within an increasingly disparate sense of Britishness. Insular, fragmented, unauthentic, the community within the community of Rabbi Zweck is one of a centreless centre in a post-imperial Britain. The elected member, Norman, may stand for all the elected members who are constructed as "Other" in the scapegoated straight-jacket of society's sometimes crippling conventions and mores.

\section{Taking a Break: Stanley Middleton's Holiday}

Stanley Middleton shared the Booker Prize with Nadine Gordimer in 1974 for Holiday, a relatively simple drama about the disintegration and eventual reaffirmation of the marriage of its middle-aged, middle-class British protagonists.

Gordimer and Middleton's novels, the first two to share the Booker Prize in any one year (the second time being in 1992 when Michael Ondaatje and Barry Unsworth shared the Prize for The English Patient and Sacred Hunger), are vastly different in both style and theme. Where The Conservationist is an often tragic analysis of the condition and psyche of the pastoral white man in an increasingly unstable South Africa in which issues 
of Black-oppression are increasing within the national consciousness, Holiday is a highly conventional British drama set in a coastal seaside British holiday town, in the vein of Graham Greene, a middle-class David Storey, a less satirical Kingsley Amis, or perhaps, at a stretch, the romantic realism of Anita Brookner and Penelope Lively. The uncomfortable juxtaposition of these two co-winners illustrates both the insularity of the British cultural scene and the desire to break away from it.

Holiday is realist in mode, and events in the narrative present are interfused with recollections from the past of Edwin and Meg (its two central characters) recollections of both the near adult past of their marriage and the more distant past of their respective childhoods. While Edwin and Meg's marriage is in a precarious state, which causes Edwin to walk out and take his "holiday" from it, and while the couple are eventually reconciled, their middle-class world is largely a decentred one-a world to which neither is adjusted despite the commonality of their background. Their problem is not financial; Edwin is a successful lecturer in the Philosophy of Education at a regional university, he has inherited money and Meg has wealthy parents who help establish the couple financially. Rather, the problem is the conflicting natures of the married couple: Meg irrational, beautiful, temperamental, capricious; Edwin argumentative, rational, whimsical, intellectually compulsive. Both are egotistical. As the novel progresses we learn that they have lost a two-year-old son to influenza and this has caused psychological problems and a rift in their marriage that has not fully healed.

Meg's father, a pragmatic solicitor who is used to dealing with matrimonial cases, resolves to reconcile the two out of a genuine concern and affection, and eventually does so, intellectually sparring with the more abstract thinking of his son-in-law. Holiday suggests a "time-out" from the tradition of the serious British novel of society, a sideways perspective, a temporary outside glance at the world of middle-class British convention. In this respect it reverses the scenario of The Elected Member. There are no scape-goats in Holiday, but rather relationship problems, problems of mutual complicity among a class of people who are far from marginalised. Rather than portraying the disintegration of family life from within an insular ethnic minority (as with Rubens' 
novel), Middleton questions and ultimately consolidates the institution of marriage and the middle-class conventions of the dominant middle-class, the middle-class British protestant group against which the Jewish characters of Bernice Ruben's The Elected Member would feel the force of a social marginalisation (and in counter-distinction to which they might want to preserve their Jewish identity). Both The Elected Member and Holiday reflect the domesticity of post-imperial Britain but they represent its composition of disparate peoples, the subsuming of the "multicultural" minority within the white Anglo-Saxon majority.

Holiday has a studied aspect to it, fusing references to literature, religion and poetry within a fluid but controlled narrative. Religion and loss of meaning are basic themes within the novel: "He'd no religious belief, no nostalgia, he told himself." ${ }^{3}$ The amorphous nature of history, both in the personal lives of the protagonists and in the background of local reference, is explored in the context of the narrative present, highlighting the sensitivity of Edwin to his environment and the degree to which he feels a part of a British heritage. This for him is a liberating feeling, re-establishing a sense of being in tune with history: "He repeated (the) lines aloud; called them out again, modifying his stride to their thythm. People passed, brightly, whipped by the wind, eyeing him, ignoring. George Herbert, he thought, as he wished for equivalent faith. In the seventeenth century Edwin Fisher would have believed, but grudgingly in tatters, a sullen assentor, up with no angles. So Herbert"(10).

Edwin contemplates writing a card to his wife intimating that he still feels close to her. He decides, however, to avoid all emotion in his writing —-He'd not apologize or sulk or shout, but put down physical facts about rooms and holiday artisans and lilos till she screamed" - but instead settles ironically to read to himself a memoir of that most emotive of modernists, D.H. Lawrence. Through the subtle interweaving and juxtaposition of past and present event, mood, feeling, and intertextual reference, Middleton examines a range of emotions in his protagonists and the dissonance between effective and authentic communication and the noncommmunication and emotional distancing that has threatened Meg and Edwin's marriage. 
Edwin's seaside break is interrupted by the presence of his father-in-law, David Vernon. The two inevitably begin talking, with David reasonably and affectionately objective. In the context of the father's discussion of the daughter, Middleton makes casual and sly reference to P.H. Newby's inaugural Booker Prize winning novel, Something To Answer For (1969), the story of Townrow, expatriate adrift in Egypt at the time of the Suez crisis: "'Pity. I'm not claiming it's your fault. She's got something to answer for. . ." (13) David Vernon prompts Edwin into thinking about a possible meeting with his wife, a reconciliation, which causes Edwin to review their marriage and his feelings towards it, the central calamitous event in which was the death of their son, Donald. His thoughts about this event cause him to review their courtship and engagement-again a setting for literary reference, to Ibsen's play A Doll's House, which Meg finds unreal although she defends it from a feminist stance, and which Edwin thinks important, though "pre-freudian" (26). From the outset this initial meeting of the couple intimates the nature of the novel, the moral drama, that follows. As Edwin puts it in the context of Ibsen: "'But we get pleasure, a marvellous pleasure, don't we, out of seeing men and women face up to, and even be defeated by fearful events?'" To which Meg replies perfunctorily: "'You might. I don't'" (27).

In Holiday, the kind of English attitude to the Welsh that Kingsley Amis satirises so closely in The Old Devils, is pervasive, perhaps in unwitting echo of Amis's novel Ending Up published in the same year as Holiday: "'A scruffy little pub, David said, not the sort of place either of you might be expected to patronise.' For a second, he detected a Welshness of intonation, a parody of her husband in the sentence's formality. $\mathrm{He}$ dismissed the suspicion; Irene Vernon carried no satire round with her" (37). Welshness represents the "Other" to the Anglo-Saxon majority. David Vernon, however, is of Welsh origin, and the Welsh are portrayed in slight deviation from the norm which Edwin supposedly represents.

Holiday, while accomplished, lucid, tightly interwoven drama, strikes the occasional false note. Edwin contemplates writing a play throughout the novel, in celebration of the occasion of meeting his wife, and this is revealed to be something which he has always 
intended doing. This appears as a conscious device to suggest his inner turmoil and confusion and strikes a discordant note which might not, after all, be unuseful to the novel's purpose: "His play when he wrote it, would feature a man, half-way to age, sitting on a sand-dune calling out, like the young Tennysons at Mablethorpe, swooping lines of verse to the sea whose choppy wind would bundle the syllables back shattered and shredded. O, Beckett, Beckett" (41).

Time wasted-the shortage of time, a feeling of asynchronicity, entropy-is a common theme running through British fiction since the Second World War and bears a relationship to the fragmentation of the British Empire and the post-imperial era following the Suez crisis. Holiday follows some two decades—a significant gap-after the Suez crisis and continues the same hesitance that Britain displayed in its foreign policy. The sense of notalgia and domestic redundancy is illustrated comprehensively in the novel. As Edwin reflects: "A wealthy man drove twenty miles to drink a cup of cheap coffee because that was, perhaps, one of the few ways he had left to amuse himself. As a sentence, that made sense, but was deeply unmeaningful and fatuous" (84).

Middleton's theme, through the dismantling and ultimate promise of a rebuilding of Edwin and Meg's marriage, is one of the questioning and ultimate reaffirmation of conventional middle-class Englishness. Holiday is indicative of a pause and reexamination of the place of England and things English in the marriage of Edwin and Meg. In this respect it represents within England what P.H. Newby's Something To Answer For attempts to demonstrate from without. Both can be read as reflective of the place of Britain in the mid-twentieth century and after:

Amusements and stalls were not well patronised, and in spite of noise the place seemed languid. No life here, either. One or two men shouted across as he passed, inviting him to try his luck with a dart or rifle, but they cared as little as he. Whether it was merely the time of the day he did not know, but the whole gave the appearance of running down, of being old-fashioned, unwanted. One-armed bandits, bingo 
halls with cups of tea and large, precise bonuses were here too, but they lacked the glitter, the faceless comfort of the newer palaces on the front (95).

Of all the Booker Prize winning novels, Holiday remains the most indifferent to the fact of empire. Ironically, of all the peoples involved, the English like Meg and Edwin, (not the British) are the people who perhaps remain most indifferent to the passing of an era. For Edwin and Meg, among the first generation of the post-imperial age, have already forgotten India, Africa, and the Caribbean, and empire never signalled anything truly important to them except teams to play cricket with.

Its domesticity and "Englishness" aside, Holiday is burdened with passages of marked discordance: "Fisher half-amused, looked for the language of the youth cult, the words he'd learnt from the Sunday papers, 'chick', 'pad', 'joint', 'turn on', even the daft 'psychedelic', but found nothing. ... In the distance a young couple silhouetted with all the banality of a television ad ran hand in hand so that they seemed immediately conspicuous by their directed energy, their aim" (95-96). It is difficult to make sense of this passage, whether it implies that Edwin is being portrayed as an outsider in the context of his own middle-classness, or whether his internal disruption is being foregrounded in the descriptive present, or whether Middleton is (unconvincingly) invoking the surficiality of a depthless consumer-driven present (in the manner of Kingsley Amis but without the humour) with reference to a more glorious past. Holiday also reveals stylistic oddities which are characterised by Middleton's juxtaposition of opposites. Thus, for example, the almost gothic incongruity of the following: "The motor-mower ripped the air, the place had the stillness of waxworks" (91).

Ultimately, Meg and Edwin are reconciled largely through David's artifice. The novel ends with Edwin remembering his father, Arthur Fisher, a reasonably wealthy shopowner, and a man for whom Edwin had mixed affections, pronouncing "'I'm glad to be home.'" Middleton's concern with a comfortable continuity between one generation and the next, the stability of middle-class England in the dissolution of empire, is thus 
reinforced at the novel's conclusion. The confused stylistic mannerisms of Holiday, the maintainence and reinforcement of stereotypes, the stylistically incongruous descriptive juxtapositions mean that, for this reader at least, the novel is an unsatisfactory co-winner of the Booker Prize.

\section{Nature or Nurture: David Storey's Saville}

Saville is the fourth in a sequence of four novels conceived by Storey as ". . . a sort of campaign for reintegrating myself." 4 The reintegration that Storey sought was from the double life split between professional football for Leeds Rugby Club and a successful art education at the Slade School of Art in London; a working-class background and success in what is often perceived as the largely bourgeois world of the arts and education. As John Russell Taylor suggested in 1974:

The great British sang-froid, literary and domestic, would seem to be associated with the rise and hey-day of British imperial power, with the consequent obligation to behave nationally like parents in front of children, teachers in front of pupils, officers in front of men. . . But things have changed. Almost without our noticing it, the British Empire has melted away, and suddenly a generation has arisen for whom Britain is only a tight little island, a second-rate power at best, and there is no need any more to keep up appearances . . Storey is not, emphatically not, a gentlemanly writer-not only because he belongs to the new class of writers who come from a working-class background and feel no necessity to give themselves a respectable bourgeois protective colouring, but also because the very concept is outdated: the English gentleman, paralysed by his stiff upper lip, is as much an anachronism as the nanny or Bradshaw's Railway Almanack. ${ }^{5}$ 
Storey's Saville should be understood not only in terms of the writer's own unusual life but also in terms of the society which produced it and the reflection of that society within it. One of the central concerns of Saville is its blurring of content and genres, the suggestion of familiar and established British themes within a literary form with which they have hitherto not been associated: the modernism of D.H. Lawrence, the pastoralism of Thomas Hardy, the sensibility of the "Other" in the colonial-chronicler E.M. Forster.

Storey's novel is above all reflective of wider changes in the world after empire. There is an emotional freedom in Saville which has neither the distancing irony or clever understatement of the Victorian novelists like George Eliot or Charles Dickens nor the exoticism of the imagist moderns like Malcolm Lowry or Lawrence. It is a freedom born of recognition of the failure of the social system within Great Britain itself, and with it the chance for self-expression that such recognition brings to one who is not implicated in that failure. Storey's novel is one of coming to terms with, and desiring to transcend, a British imperial entropy within a regionalist working-class setting.

From the point of view of its sensitive, educated working-class protagonist, Saville examines the veil of pretence and false appearances that surrounds the South Yorkshire community of Saxton. Storey portrays the working-class "victims" of a general depression from within the imperial system whose children, having "benefited" from the educational privileges of empire, are now more equipped to see the injustices of the society which shaped them. Not only is empire challenged from without but, as Saville shows, it is challenged from within by an increasingly embittered meritocratic workingclass who see the injustices of the system without the rhetoric of justification of their forebears. The frustrations experienced by this displaced generation are symptomatic of the centreless nature of their lives. Educated out of one class, they do not share the emotional register of the next. The result is a sense of displacement and frustration, a desire for travel, and above all a desire for meaningful identity. Within this framework it is not so much the emotions Storey's protagonists experience that are new but that the style and tone of the discourse which expresses and encapsulates them. 
However, it is not true, as Taylor claims, that Storey can be seen ". . . as our first truly modern novelist because for him the traditional obstacles thrown up by middle-class education and the gentlemanly tradition of understatement are not consciously overcome; they quite simply do not exist", for that presumes that to be a truly modern novelist (whatever that is) the writer need be independent of middle-class concerns and the gentlemanly tradition, the relationship of which to modernity Taylor does not explore. ${ }^{6}$ The middle classes and the modern novel are not mutually exclusive terms. Nor is it true that the traditional obstacles thrown up by a middle-class education and the gentlemanly tradition do not exist for Storey, as his whole genre must wittingly or not be defined against such obstacles and traditions. The fact that he does not ostensibly participate in them is altogether separate and different. Admittedly, Taylor is writing before the publication of Saville, which perhaps brings to culmination Storey's preoccupation with the class system and the attempts of his intelligent protagonists to transcend it. The confidence of white British middle-classness is the hegemony which Storey's novel contests. Saville depicts the internal struggles of a nation after empire.

In demonstrating the disparity between the lives of the young school pupils and the rhetoric and distilled systems of empire which form the content and structure of their education, Storey reveals the social dissonance of a changing Britain:

'Certain unfortunate nations may use the decimal system because they have nothing to fall back on, Stephens. . . . Whereas we, in this country, and in those lands that constitute our empire, and our dominions, Stephens, use a measure which, for better or worse, is peculiar to ourselves. Peculiar, that is, to an imperial nation. Imperialis, imperium. To a nation which is used to authority, to dominion, Stephens. How many pennies in a pound $?^{17}$

Saville shares some of the concerns of John Berger's G. Colin could well be a "G" figure within the Saxton community. His recourse to women as a form of liberation and 
escapism, from whom he learns as much as he instructs, is similar to Berger's escapism in $G$. Where $\mathrm{G}$ is "apolitical", Colin is anti-political, finding hypocrisy and stiflement in the political subtext of the community around him, from which he is formed. Breaking free from one class, he is ill-equipped emotionally for the next. Colin's personality, sensibilities and intellect are quashed by the social values of Saxton and implicitly those of an increasingly insular Britain. Despite this, he cannot escape into the old school world of adventure like Stafford or, because of his innate Christian faith, the polemical and opportunist media-driven world of Stephens. He is trapped by the cloak of conflicting social classes and values. In faint intertextual echo of Berger's $G$., as if in parody of the obliqueness and overtly metafictional narrative of Berger's post-modern novel, and also of the name of Saville itself, the ultimate pathos of the novel is underlined by Storey in a passage of almost imagist beauty. Taking the bus home home one night near the conclusion of the narrative, as the sun is setting over the mills, Colin hears a voice, which could be that of the omniscient narrator, state: "'It could be Italy,' . . . and when he turned a man gestured off towards the river. 'Italy,' he said again, indicating the yellow light" (501).

Storey's novel quietly, confidently, eloquently, anchors a sense of dignity for the British regionalist and regional novel. Its is a form of social realism that is engaging in its breadth, depth, pathos, and vision. Implicit within the novel is a subtext of imperial entropy and yet in differing ways and with differing degrees of comprehension the characters within it try to transcend this general entropy in respect of their own particular desires, personalities, choices, and decisions. However, social realism is not a completely adequate label for Storey's novel for there is a distancing and ironic detachment of the omniscient narrator that intimates the intertextual and anti-realistic characteristics of the author's later plays. Saville cannot be positioned comfortably in any one genre. This is a strength in a novel whose protagonist cannot fit into any one social niche. As Janelle Reinelt puts it: 
Storey's protagonists, like himself, are those sons who by education and talent extend themselves beyond the ideological limits of their class background, and find themselves confronted with the futility and empty promise of the middle-class life their parents endorsed. Brought up to feel obligated to provide a kind of redemption for their parents' lives of poverty and struggle, as adults their own inadequacy to this impossible task brings them to crisis. ${ }^{8}$

Colin's crisis in Saville is one of identity - a kind of suspension between classes and a repulsion for each in the insular community of Saxton. However, to interpret this response to insularity as an emphasis on the Oedipal in Storey's work, as Reinelt does, is overly ingenious at least as far as Saville is concerned. Colin does not "seek first to return, somehow, to the womb, to retreat from the world . . ."9 Rather, already isolated and disengaged, he seeks to re-engage with it, but somewhere other than in the place of his upbringing, which he ultimately leaves.

Saville is almost contradictorily a "pastoral" novel of British regional town life. It is an engagingly unsentimental novel of pathos. It portrays a regional English town from a predominantly working-class perspective. Colin is lifted above his peers by the classical education he receives, founded on the now declining rhetoric of empire which allows him to see more than the stoic provincialism of his parents. Yet he remains emotionally frustrated and stifled by the middle-class society he encounters and the systems of social construction behind them; he is cast out, alienated, disengaged, adrift. The nostalgia of the novel is an ironic one for a "golden" Europe, a renaissance glimpsed across a river which could be Italy, but which is actually the light shining on the mills and coal pit behind. 


\section{Curtain Call: Iris Murdoch's The Sea, The Sea}

A professor of philosophy at Oxford University; a C.B.E and D.B.E.; author of over twenty novels, a volume of poetry, and academic books-Iris Murdoch has had a long career of both literary and philosophical distinction. Her novels interweave the psychological, philosophical, religious and moral in narratives of twentieth-century British and Irish society.

More than perhaps any other post-war British novelist with the possible exception of William Golding, she has plumbed the archetypes and mindscapes of late twentiethcentury middle-class British society—a society that she interprets as prolific with literary, philosophical, and psychological allusion. With Murdoch the novel becomes a stage, a metaphor for consciousness. Murdoch's novels are ambiguous, open-ended, complex and self-critical. Her white, predominantly middle-class British characters have complex emotional and mental lives and her novels are often infused with a sense of eastern religion or magic, whereby Murdoch confronts the search for meaning in contemporary British society.

Conceptually-driven, Murdoch's novels are entertainments which explore tapestries of human metaphysics and morality. As Suguna Ramanathan puts it:

She goes beyond the ordinary and normal . . . these improbable possibilities which she chooses to present are actually externalisations of the endless combinations, often mutually exclusive and contradictory, that lie at the bottom of consciousness. Anything and everything may be entertained there; behaviour is regulated and made decorous only through socialisation. Exclusion, choosing, acting in certain ways rather than others, are constructs placed over a seemingly bottomless, surging inner sea. It is this innermost, interior seascape that Murdoch is disclosing; it is therefore, hardly surprising that it seems unrealistic to the socially conditioned consciousness. On the other hand, from the moral point of view, it appears as inescapably and 
profoundly true because moral principles lie like bridges over the swirl, and derive their importance and strength from the dark flux they span. ${ }^{10}$

The Sea, The Sea (1977) stands roughly at the mid-point of her work. It is in the tradition of Murdoch's "gothic" novels, similar in atmosphere to the earlier The Time of the Angels (1966), and Bruno's Dream (1969). Obsession is the key theme of the novel. The principal protagonist is a retired playwright and stage director, Charles Arrowby, who retreats in what he imagines is a serene withdrawal from the world in a remote seaside house to write his memoirs. From the outset of his chronicle his consciousness is interrupted by a distorted vision from his unconscious which fractures both the stable world of Murdoch's novel and that of Charles's own mental seascape. Threatened by this interruption to his "normal" narrative, he must re-write his memoirs in an attempt to account for the disruption. A variously placid and seething British coastline plays backdrop to Charles's own mindscape.

The novel is divided into three sections: "Prehistory", "History", and "Postscript: Life Goes On". The reader knows from this that at the outset something has happened to the protagonist(s), there is a (hidden) cause for it, and that the protagonist survives the events. Arrowby's narrative, in characteristically Murdochean fashion, resists closure. Within the first few pages the writing of autobiography, philosophical journal, memoir, diary, and cook-book are contemplated as occupations for his retirement-all this interspersed with self-concerned quasi-philosophical self-analysis and reflection on the paradoxes of identity:

To repent of egoism: is autobiography the best method? Well, being no philosopher I can only reflect about the world through reflecting about my adventures in it. And I feel that it is time to think about myself at last. It may seem odd that one who has been described in the popular press as a 'tyrant', a 'tartar', and (if I recall) a 'power-crazed 
monster' should feel that he has not hitherto done so! But this is the case. I have in fact very little sense of identity. ${ }^{11}$

The irony and self-obsessed nature of Arrowby's comments are self-evident, as well as the contradictory conundrum of Murdoch's theme. This passage contains all the elements of Murdoch's novel in microcosm: self-obsession, a questioning of narrative as authorial representation of the self, the problems of identity in the social construction of public and private spheres, the apparition of a "power-crazed monster" who has little sense of personal identity, the world of the theatre as the stage for life's events, a desire to be good that is born of inherent moral complexity and a climate in which there has been a self-professed "moral change" (3).

As Charles becomes accustomed to the solitude of his villa on the sea's edge, "Shruffs End", and as he begins to write his autobiography (between his reveries, swimming, and meal-making), the house and environs take on an aspect of Charles's own mindscape. The house itself is "mysteriously damp" and the situation "exposed and isolated" (10). He explores it as his consciousness might explore the states of his mind. Charles is attracted to the villa at the coastline because "there is deepish water up against the rocks at any state of the tide" (12). The stable world is constantly threatened by something (the sea, the sea) beneath normal perceptions of reality: "I prised up some linoleum in the hall, and replaced it with a shudder. There was a salty smell. Is it conceivable that the sea could be rising up through a hidden channel under the house?" (14) While almost narcissistically preoccupied with his own reflections, both in the form of memories and literally at one point reflected in the black glass of large oval mirror in the entrance hall, Charles autobiographically reveals that he is "still almost shy of [my] emotions, shy of the terrible strength of my own memories" (17).

The culmination of Charles's mental instability takes the form of the apparition of a sea-monster which he sees as an immense black snake with a long thickening body rising in a swirling pool in the seas a quarter of a mile from his cliff face: "I saw a monster rising from the waves" (19). The monster, while metafictionally taking the form of 
Murdoch's fictional creation "the sea, the sea", is interpreted by Charles as either a trick of the retina in transposing an image of a bristling sea-worm he had been studying in a rock pool onto the sea itself, or more probably as the re-occurrence of an image from a bad LSD trip that he had taken years before. He is shaken by his experience and the seamonster stands sentinel to the gateway of Murdoch's novel of the troubled consciousness of her retired actor and director.

The Sea, The Sea contains subtexts of Shakespearean, Buddhist, and magical reference. Charles reveals that he was born near Stratford-upon-Avon into conventional British lower-middle-class origins and he "owes his whole life to Shakespeare". He received his first calling to the theatre and acting from an enthusiastic Shakespearean schoolmaster: "I fled to the trickery and magic of art. I craved glitter, movement, acrobatics, noise" (29). His father was a gentle, "bookish" man, and Charles was reared on texts of imperial and colonial adventure like Treasure Island, adventure stories, children's books, novels, biography, poetry and, of course, Shakespeare at the encouragement of his father. The play that in particular is in the background of the novel is The Tempest-a play that has been subjected to many recent post-colonial readingswith the role of Prospero, the philosopher marooned on an enchanted island, falling to Charles (ironically we are told that this was the only acting role in which Charles excelled). ${ }^{12}$

The magical "vision" of the sea-monster is followed by the unexplained smashing of a vase and the oval mirror, and the apparition of a face at the window. Charles dismisses these phenomena rationally, yet at the back of his mind are thoughts of poltergeists and magic. Murdoch's novel, like The Tempest, becomes concerned with, as Lindsey Tucker puts it, the "surrendering of magic", ${ }^{13}$ with Charles as the tyrant-directormagician: "The theatre is an attack on mankind carried on by magic: to victimize an audience every night, to make them laugh and cry and suffer and miss their trains" (33). There is a shade of nastiness about Charles. As a director he was a "tyrant" and dictator: "If absolute power corrupts absolutely then I must be the most corrupt of men" (37). To his theatre friends Charles has been a magus figure and manipulator. His own plays 
"always intended to be ephemeral" and "exist[ing] only in my direction of them" were "magical delusions, fireworks" that he never let anyone else touch (35). The theatre is a "place of obsession" (34) that mirrors reality as a place of "hopes and disappointments and in its cyclical life one lives it in a more vivid way the cyclical patterns of the ordinary world" (36). Charles has come to Shruff's End for his retirement, to write his autobiography/memoirs/novel/cook-book, and to "learn to be good". The question for him soon becomes: "Have I abjured that magic, drowned my book? Forgiven my enemies? The surrender of power, the final change of magic into spirit?" (39)

Before long Charles is summoning figures from his coast to his retreat on the cliff's edge and directing them as he would characters in a play, exercising a dominance that verges on the obsessional and self-deluded. His past, he reveals in passages of almost unbelievable self-concern, to be littered with relationships to which he could not commit, remaining in them long enough to ensure the devotion of the other and then leaving, as if to assert his dominance by walking out. The "real" world is just a stage for Charles; the theatre and reality are blurred.

Murdoch's novel thus echoes The Tempest. Charles is a Prospero figure, who soon acquires a Caliban in Gilbert, who performs the menial tasks of the character in Shakespeare's play. Charles is later joined by cousin James, another Prospero figure, who holds the key to the novel's "magic" in so far as he is a practising Buddhist, secret agent, and mentalist. Lizzie, "wispish enchanting rather infantile sprite" (50) is an Ariel figure and under a kind of bondage to Charles' egotism: "(In fact the harem situation would suit me down to the ground). Why can't Lizzie be intelligent enough to understand? . . . I must confess I still have feelings of ownership about Lizzie" (48). Rosina, another figure out of Charles's past, resembles Sycorax, Caliban's witch-like mother. As Lyndsey Tucker points out, Murdoch uses the allegory of The Tempest to "explore states of enchantment." 14 However, The Sea, The Sea is not simply a reworking of Shakespeare's play but, juxtaposed with elements of Buddhist teachings and thought, a novel about art capitulating to life, the surrender of magic and the ego, and a "rehearsal" for death. The Sea, The Sea is a morality play that is intershot with 
metaphysical devices, all of which challenge traditional conceptions of the "normal" and the "conventional". The Buddhist elements, references to nirvana and the wheel of rebirth, are to be read as counterpoint to Christian interpretations. They inform James's mysterious background (in the form of Buddhist relics in his flat), and render enigmatic passages of metaphorical description:

Since I started writing this 'book' or whatever it is I have felt as if I were walking about in a dark cavern where there are various 'lights', made perhaps by shafts or apertures which reach the outside world . . . There is among those lights one great light to which I have been half consciously wending my way. It may be a great 'mouth' opening to the daylight, or it may be a hole through which fires emerge from the centre of the earth. And am I still unsure which it is, and must I now approach in order to find out? (77)

Charles's cavern is his mind, a symbolic representation of his psychological condition. He has "bad Karma". He continually equates "light" with "purity", "love", "good", and an innocence lost. Buddhist thought maintains that for every life, and in every human consciousness, there is an element by which the soul may attain the absolute. If it does not do so it is because it mistakenly concentrates on the self (avidya). For the Buddhist this preoccuption with the self is the root of delusion and evil and prevents proper seeing - that which is whole seen as fragmented (samsara). To be reborn is to be immersed in samsara-sagara or the ocean of existence. ${ }^{15}$ In Charles's description of wending his way to a great light is a quest for the absolute (nirvana) that he is frustrated from achieving (but which James does later achieve). During a return to London, Charles finds himself contemplating Titian's painting of Perseus and Andromeda. He is taken ill by its invocation of what seems like his serpent vision. Cousin James appears on the scene and, reviving him, says "'we cannot just walk into the cavern and look around. Most of what we think we know about our minds is pseudo- 
knowledge'" (175). The Buddhist theme is traceable in numerous ways in The Sea, The Sea: it is possible to interpret the novel as a metaphor for the bardo experience, and the ultimate transcendence of this to the next stage of sangsara pilgrimage on the Wheel of Life.

However, Buddhism, like the references to The Tempest, unlocks meaning in Murdoch's novel. Interesting in itself is the replacement of Christianity with Buddhism as the major religious concern. Murdoch is all the more extraordinary for managing to confine a subtext of Buddhism within what is essentially an English novelistic tradition. She is also ostensibly a modernist writer: at the heart of her novel is a belief in a "real world" attainable through a rehearsal of moral experiences, or altered doors of perception. Modern society, she seems to be saying throughout her oeuvre, is something that obstructs people from their real selves. This "real" self does not seem to have the darkness or apocalyptical qualities of Golding's inner-human, but is a measure of both Caliban and Prospero, chained and unchained, good and bad. If there is one overriding message in all her novels, including the Booker Prize winning The Sea, The Sea, it is to "look again"; life is more complex than one thinks.

Iris Murdoch's "Englishness" is that of a middle-class intellectualism. Her strength is in showing that this world is potentially as rich in cultural reference and emotional repertoire as any other; she explores the human condition through her largely middleclass characters and their foibles and motivations. Her novels are both sophisticated and contrived. They are stages for mental acts.

While she is dissimilar to the contemporary British female writers like Penelope Fitzgerald, Anita Brookner, Margaret Drabble, and Penelope Lively, Murdoch shares something with the earlier John Fowles, in particular the conception of his novel, The Magus. A figure in Tarot, the Magus is a master magician or juggler, or trickster. In Fowles' novel the "Magus" is an enigmatic' social manipulator. Like Murdoch's The Sea, The Sea, The Magus is concerned with the nature of reality and evokes a mental world of altering perceptions, in which people are imprisoned in the egotism of others. In her novels Murdoch attempts to make an increasingly fragmented world make sense in all 
its complexity. This is an impossible task, however, in the age of the death of the author and subject. The reality towards which she gestures inevitably eludes her attempts to describe it.

As one literary mannerism evolves into the other, the high modern into the demotic post-modern, Murdoch's fiction strives to locate a universalism within its middle-class British cast. Her novels depict life at the changing core of Anglo-centricity. They are superbly crafted and meticulous productions of their kind, but they are written in a world in which qualities of "timelessness" are euphemisms for the anachronistic. Because of this change, Murdoch's complex theatrical, fictional, moral world speaks ultimately of the increasingly de-centred and unfamiliar nature of a changing British society after empire $^{16}$

\section{Empire's 'Twilight: Kazuo Ishiguro's The Remains of the Day}

Imperial entropy and the character of British post-imperial anachronisms form the basis of Japanese-born Kazuo Ishiguro's 1989 Booker Prize winning The Remains of the Day. Set during the summer of 1956, Ishiguro's novel recounts the story of Stevens, an ageing butler at the grand English country house of Darlington Hall. Stevens, who has spent a lifetime in dedication to the profession of service to the late Lord Darlington, functions as a metonym for British culture as mediated through the critical gaze of Ishiguro. Prompted by his new American employer, he embarks on a six-day motoring trip to the West Country. Stevens's travels are disturbed by memories of his long years of service in Darlington Hall and the anticipated visit to his lost love, the ex-housekeeper of the hall, Mrs Kenton.

Ishiguro's novel is at once a comedy of manners, a nostalgic story of lost causes, a study of personality, and a critical analysis of the British class system and aspects of its mid-twentieth century culture including political illusion. The novel shares a similar preoccupation with the effects of memory and time as Ishiguro's previous novels of exile and displacement-A Pale View of the Hills (1982), and An Artist of the Floating World 
(1986). In doing so the novel plays intricately with the voice of the narrator and the notion of the subjective. Stevens is an unreliable narrator and the conflict between his professional demeanor and his subjective feelings, established through Ishiguro's manipulation of the narrative voice, provides much of the interest and technical sophistication of the novel. As Kathleen Wall puts it: "Ishiguro's . . . novel is as much about unreliability as it is about the conflict between public and private personae, between profession and human duty, between the facade of dignity and the expression of emotion. Indeed, Stevens's narrative unreliability is a key means through which these conflicts, largely unresolved for him, are demonstrated."17

While he is the very epitome of English social decorum, reservation, modesty of opinion, immaculate dress and service, the perfect gentleman's gentleman, Stevens's knowledge of England outside Darlington Hall is derived either second hand from visitors and acquaintances or from books such as Mrs Jane Symons's The Wonder of England, written during the 1930s which he peruses before his motoring trip, which takes place in the narrative present of 1956: "I had not looked through these volumes for many years, until these recent developments led me to get down from the shelf the Devon and Cornwall volume once more."18 Ishiguro's sensitive irony is confined by the reader's knowledge of Stevens's gentlemanly anachronisms and the fluctuations in the reliability of his narrative viewpoint perceived from the extra-textual knowledge the reader brings to the setting. Again as Wall puts it, "Ishiguro's novel, by both facilitating and frustrating the process of figuring out 'what really happened' not only refocuses the reader's attention on the narrator's mental processes, but deconstructs the notion of truth, and consequently questions both 'reliable' and 'unreliable' narration and the distinctions we make between them."19

Stevens's identity is confined by his service at Darlington Hall and his whole life centres around his function within it. Prompted by the "bantering" of the new owner (who is an influential American business "gentleman" from Lord Darlington's past) and a letter which re-kindles a love interest from the days before the war, Stevens is forced to review his life of service at the Hall. He does so with the reserve with which he does 
everything else, not so much to reconcile the past with the present but with a gradual and growing awareness of the repercussions that his life of impeccable professional service has had in subsuming and defining any notion of a private existence. With the death of Lord Darlington he becomes aware that he is now the very cornerstone of the old Darlington Hall and the last link in the social foundation on which it was built, an anachronism, the bastion of an era now past. Under the guise of the need to revise his staffing plan, Stevens attempts to recruit the services of his lost love, the former housekeeper at Darlington, Mrs Kenton-Stevens embarks on his motoring trip to the West Country that inspires a revery of his role as butler against the background of the English countryside. As M. Griffiths points out:

The country house has been a resonant, recurring and dynamic symbol of "Englishness" in fiction from Emma onwards. Throughout nineteenth-century fiction the country house becomes both the actual refuge of the prosperous middle-class industrialists from the blighted cities where they made their capital and repository of the spoils of empire. Over the century, the houses themselves lost their traditional focal position in the landscape as sites of social and economic power but they represented a powerful social myth of harmony and order in the "Edenic" garden of the English countryside. They became iconic: ground over which different constructs of "English values" could be contested. The exchange of values which took place as the middle class married in or took possession of the houses tended to inflect the structures of power in changed ways. ${ }^{20}$

This reading of the role of the country house reflects Nadine Gordimer's construction of Mehring's pastoral retreat in her novel of colonial and post-colonial white South Africa, The Conservationist. While such houses were themselves models of the English country house and may have represented a powerful social myth of order in an "Edenic" 
garden, they did not necessarily represent one of harmony, as Gordimer's novel of social malaise is testament to. In Britain, however, country houses were sites of economic and social power. Grounds for the construction of "English values", they had strong ties with British imperialism and concomitant with this was the British construction of an inflexible class society based on the legacy of feudalism. As Raymond Williams observes: "The landed aristocracy had lost much of its particular identity and its political power in the course of industrialist and imperialist development. But its social imagery continued to predominate. The network of income from property and speculation was now not only industrial but imperial. And as so often before it was fed into a selfconsciously rural mode of display." 21 With the decline in empire and the waning of the influence of the aristocracy together with the ascendence of the monied and emancipated bourgeois industrialist, a new social order emerged, although largely within the terms of the old class system. Money could purchase the privileged lifestyle of the aristocracy but not the traditions and historical associations by which they were constituted. Thus, Darlington's new owner, the American Mr Farraday, purchases what he thinks is a slice of authentic British upper-class tradition.

A changing Britain and a resurgence in British nationalism in the Thatcherite Britain of the 1980 s brought about a national consciousness that was primed for the rediscovery of an image of itself in terms of an "authentic" English past. Thatcher's conservativism promoted a return to "Victorian Values" which were constructed in imitation of the original values, and appropriated for the conditions of contemporary society. It is within this socio-political climate that Ishiguro's novel is conceived, and it is this ideological framework which he engages with and subverts. In demonstrating a return to a "nonexistent mythic past", Ishiguro describes a society which seeks to provide itself with a bankrupt cultural identity, a "centre-less centre". As Stevens himself observes, "I suppose I was very conscious of the fact that once I departed, Darlington Hall would stand empty for probably the first time since the day it was built" (23).

The return to a nostalgic past is a phenomenon that is not confined to the new nationalisms prompted in the wake of Britain's post-imperialist decline. It is probably, 
however, a condition brought about by the influence of imperialism in colonial conditions operating in conjunction with the nostalgia-mode of post-modernism. Ishiguro's The Remains of the Day makes the contrapuntal acknowledgement that a changing, much reduced Great Britain must come to terms with itself within increasingly multicultural parameters. The Remains of the Day examines the bankruptcy of the notion of a rigidly English nationhood in confining a narrative of the empty houses of British imperial order. To be British now is to be among a multiplicity of races and peoples. Multiculturalism forms the contrapuntal text of The Remains of the Day. The author himself is testament to the fact that Britain is a post-colonial nation and that a new national identities emerge not only from a nostalgia for the old, but from the wider acceptance of the diaspora of a post-imperial internationalism. However, the sense of a cultural recoil that The Remains of The Day participates in is something that Timothy Brennan observes in his essay "The National Longing for Form": "The terms of nationalism have from the European perspective apparently reversed. Not freedom from tyranny, but the embodiment of tyranny. The question is: how much is this new perspective a result of owning, rather than suffering, an empire? That is, can't it be said that the recoiling from nationalism is also partly due to the challenge of the rising national movements of the developing world?"22

The Remains of the Day becomes an allegory of imperial decline, and the anachronisms and idiosyncrasies which make up the British and international conception of the stereotypes of British imperial character. Through Stevens, Ishiguro parodies, celebrates, ironises, and salutes the notion of an increasingly displaced parochial gentlemanly English type. His novel is one of assumed and wry nationalism that ironises the anachronistic character of the British imperial era. The world of Stevens is over, and the novel recaptures a whimsical and nostalgic view of this, while celebrating its final moment.

The novel is narrated by Stevens in his detached, modest, and circumlocutory tone, what Galene Strawson calls his "plonking but catching, sub-Jeevesian, PC Plod Witness Box English". ${ }^{23}$ His is the central consciousness whose voice is virtually 
indistinguishable between outward speech and inner thoughts. Stevens stops first in Salisbury, where his immaculate suit, his employer's Ford, and address of Darlington Hall provokes the snobbery of the owner of the guest house where he stays, all the more ironically as she presumably mistakes him for Lord Darlington, his former employer: "She informed me that a double room at the front was available, though I was welcome to it for the price of a single" (27). Stevens ruminates on the grandeur of the English countryside that he observes, comparing it favourably with the world outside which he has only glimpsed through encyclopedias and the National Geographic magazine. The "objective" analysis of its greatness he reads onto the character of the nation:

We call this land of ours Great Britain, and there may be those who believe this is a somewhat immodest practice. Yet I would venture that the landscape of our country alone would justify the use of this lofty adjective.

And yet what precisely is this 'greatness'? . . I would say that it is the very lack of obvious drama or spectacle that sets the beauty of our land apart. What is pertinent is the calmness of that beauty, its sense of restraint. It is as though the land knows of its own beauty, of its own greatness, and feels no need to shout it. In comparison, the sorts of sights offered in such places as Africa and America, though undoubtably very exciting would, I am sure, strike the objective viewer as inferior on account of their unseemly demonstrativeness ... The whole question is very akin to the question that has caused much debate in our profession over the years: what is a 'great' butler? (28-29)

The qualities that Stevens instils in English "greatness" are the qualities, he reflects, that are inherent in both the countryside and its correlative in social demeanour. What makes the countryside (and a butler) great, is calmness and restraint, the lack of drama and unseemly demonstrativeness. Stevens's ruminations are all the more ironic for his 
misinterpretation of the sense of "Great" in Great Britain. The greatness does not of course refer to the qualities of countryside but rather to the greatness of its now declining empire. Great Britain stood for the imperial nation that dominated a quarter of the world's land mass in the Victorian era. Greatness meant "rule" over colonies and colonised peoples, political, geographical, economic, psychological and social. It meant the displacement of indigenous peoples in the colonies and their replacement with those of British stock. The paradigm of the country and the city became that of England and empire. However, the greatness of empire in The Remains of the Day is turned inwards, a quality observed within the nation, whose countryside is rapidly being engulfed by cities in the post-war expansion, and whose traditions of stately Englishness are increasingly anachronistic in the changing world of imperial decline.

In constructing Stevens's story, Ishiguro subtly endorses the qualities of the society which he critiques. Born in Japan and having received an English university education, and now living in London, Ishiguro is of one of a minority group in his adopted homeland. It is perhaps Ishiguro's dual status as immigrant and British subject that gives him the freedom from the society he writes about and the detachment necessary to penetrate its values and mannerisms with such precision. Belonging to two cultures Ishiguro is able to both participate and stand apart. This double role is evident also in Stevens's unreliable narration. Stevens ostensibly has the apolitical detachment of the observer, but he cannot help but be an intrinsic part of the society he observes. Ishiguro maintains a more strict detachment, a further distance which lends greater irony and penetration to his observations. When Darlington has only one guest to dinner, Stevens's job becomes the hardest in having to wait at two ends of the large table while striving to make his presence unfelt. As a consequence he retreats largely to the shadows and trades his invisibility for the echo of footsteps to the table. Here Stevens's position is remarkably similar to that of the author, Ishiguro. Ishiguro is virtually undetectable as author within the narration of blanket detachment of Stevens's reminiscence, but his footsteps both into and away from the culture he is describing are echoed in the footsteps of Stevens's memory, disturbance and increasing disenchantment. In waiting at such a 
table, Stevens finds it: "most difficult to achieve that balance between attentiveness and the illusion of absence that is essential to good waiting" (72). Here Ishiguro is making metafictional comment on the act of writing. There is a parallel between Stevens's waiting and the author's manipulation of narrative distance.

Seen through Stevens's rigid form of enlightenment, Ishuguro's novel is thus a parody of the decline of empire. As Griffiths again puts it: "The novel is a witty, considered treatment of the untidy endings of empire." 24 However, Ishiguro's novel is more than this. The Remains of the Day is an ironic study also of the effects of a rigid pursuit of the qualities of objectivity, a detachment from emotions, and "professionalism"- those virtues of modernism that are the baggage of colonial era. A lifetime spent in repressing emotional thought leads to a dissonance in Stevens's later life: his human qualities inevitably emerge from the repressing suit of his role as implacable butler. The novel is thus an indictment against a class society that enforces values of detachment from that society.

In his dual role as both insider and outsider Ishiguro is able to dissect the pretensions, morality, values, customs and traditions of a changing Britain with a gentle precision unrivalled in contemporary fiction. The Remains of the Day is a kind of love story but it is also about the empire in twilight. Ishiguro appropriates and updates the world of Wodehouse's Jeeves, the genre of the "Butleresque", and the world of imperial decline reflected in such novels as Forster's Howard's End (1910) and Evelyn Waugh's A Handful of Dust (1934), discovering in Stevens one who reflects in that decline an unfaded sense of dignity and pathos in a changing world. Stevens's reconciliation to the possibility of a life spent in misplaced devotion parallels the recognition of the fragmentation of the old imperial order; his reconciliation to continuing and deriving simple enjoyments parallels that need for a new British sense of dignity in its reduced role in the world affairs. As Galene Strawson puts it:

The Remains of the Day studies this unspoken love, suffered first at close quarters, and then in long remembering. It records the 
accumulating costs of silence; the way denial spreads its effects, establishing complex diversionary circuitry in the mind. It examines the action of blocked regret-the dangerous loyalty of this emotion as it struggles with the devices of self-deception, and steadily retrieves and corrects the memories that give the truth, whether or not they can be understood. 25

Ishiguro's novel, while a satire, can be read as a compliment to his adopted society. Although Ishiguro exposes and plays upon late imperial entropy-through Stevens's ultimate questioning of the dignity of his life, British amateurism, and outdated codes of gentlemanly honour in Lord Darlington-he nevertheless does so with affection and something not unlike regret. In the contrapuntal reading of its satire of British gentlemanly tradition The Remains of the Day carries the implicit suggestion of a need for a more culturally encompassing British national identity in the present. As Stevens awakens to empire's twilight he castes a metonymic silhouette on a multicultural British nation.

\section{Conclusion: "Englishness" and "Domestic" Lives}

The Elected Member, Holiday, Saville, The Sea, The Sea, and The Remains of the Day are novels which reflect an imperial decline, a rapid retrenching of imperial boundaries, an English core bereft of its empire. If Great Britain is seen as the hub of empire then this idea reflects something of empire folding in on itself, a retreat towards the (absent) "centre" which begins after the First World War and is signalled in a much reduced empire by the 1960s. This retreat was also of course a form colonisation in reverse as indigenous and hybrid peoples from empire immigrated to Britain in the 1950s and 1960s such that British culture became, in effect, multicultural after the Second World War. However, the sense of British and imperial "insularities" is a response to dissolution and change as empire contracts and the process of decolonisation gathers force, a process 
largely complete by the inauguration of the Booker Prize but whose legacy continues into the present.

The novels of this chapter harbour a double sense of languor and discomfort that is both oblivious to empire and the product of imperial entropy. They revise certain characterisations of middle- and working-class "Englishness" and signal a domesticity in which various communities among the English explore, resist, and transcend the insularity of regional living and assert an identity either without regard to empire or in the shadow of its collapse.

The Elected Member, Holiday and Saville invoke a remnant of the modern bleak England of "muttering retreats" and "Streets that follow like a tedious argument", "When the evening is spread out against the sky / Like a patient etherised upon a table" that is lamented in T.S. Eliot's "The Love Song of J. Alfred Prufrock" (1915). ${ }^{26}$ Eliot's poem conjures an etiolated, sleepy, formerly industrial and industrious England, a land of former energy and magic but now "etherised" in a vision of wane and dissolution-a land fit for " . . a hundred visions and revisions / Before the taking of toast and tea." 27

If this is the vision of England as Lazarus, who in its heyday "squeezed the universe into a ball," 28 changes in the empire outside are reflected in the social structure within Britain itself, with classes being rigidly stratified and passage between them very difficult. A multicultural Britain composed of immigrant groups from the former colonies was manifest by the $1960 \mathrm{~s}$ but there was a lack of a developed and self-conscious commitment to multiculturalism until the 1990s and Tony Blair's Labour government. The entropy of empire reflects the gradual erosion of imperial confidence and frequently the symptoms of its retreat within Britain itself.

In each of these novels, England is in different ways depicted in decline because it is no longer an imperial power: Often, the societies drawn within these novels are societies that are to a large extent symptomatic of imperial entropy in the latter part of the twentieth century, acknowledging that the British foreign policy of retreat and retrenchment had psychological and sociological consequences within Britain. The Sea, The Sea and The Remains of the Day represent in differing ways and to different extents the collapse in 
confidence of the social, political, intellectual, and economic assurances under empire and the spread of imperialism. They reflect the insularity of a contemporary British nationalism, or the waning influence of Great Britain as a force on the contemporary international stage and within international affairs in the latter part of the twentieth century. The novels also reflect the inability (until recently) to articulate a multicultural Britain, or to imagine a new arrangement of internal components. They are either, as with The Remains of the Day and Saville, penetrating studies of an English cultural types (the faded aristocracy and the working class intellectual) or, with The Sea,The Sea and Holiday, illustrations of specifically English sensibilities and mindsets (the brooding romantic and the insular middle-class). The Elected Member, while more directly acknowledging a multicultural Britain, is a novel about the negative ramifications of insularity and domesticity, with family pressures and the precipitation of psychosis in its unfortunate protagonist.

By the 1960s Britain had become officially a multicultural nation with the patriation of large groups of colonial and European immigrants as empire disbanded. However, this multiculturalism would not find its way into British literature in a more dominant sense (with the notable exception of V.S. Naipaul's London-based fiction) until the 1980s and the popularity of Salman Rushdie's Midnight's Children. Multicultural policy both before and since the 1960s in Britain was vague and lacked significant focus. A policy of assimilation gave way under the "Jenkins formula" to one of embrasive diversity. As John Rex explains in 1994:

The first official British response to the presence of large numbers of immigrants distinguished by their skin-colour, their language, their religion and their culture was simply to declare that they must be assimilated to a unitary British culture. Thus the Commonwealth Immigrants Advisory Council, referring to educational provision, argued in 1964 that "a national system cannot be expected to perpetuate the different values of immigrant groups." This policy was very 
quickly abandoned, however, and in 1968 the Home Secretary said that what he envisaged was "not a flattening process of uniformity, but cultural diversity, coupled with equal opportunity, in an atmosphere of mutual tolerance" (Patterson 1968). Since these policy aims have never formally been abandoned, it may be assumed that, in some degree at least, they still influence government policy. ${ }^{29}$

Multicultural Britain under the Blair government in the late 1990s is different from the immigrant world imagined in The Elected Member largely because of the process of cultural adjustment undergone since the 1950s. A sense of being British has expanded to include the many for whom Britain is the adopted home, for example the writers Hanif Kureishi, Salman Rushdie, and Kazuo Ishiguro. However, both Ishiguro's and Kureishi's writing comment on what remains the ingrained and immobile nature of British class society (parodically in the case of Ishiguro's The Remains of the Day) and the difficulties that arise as cosmopolitan migrant groups attempt to consolidate and establish themselves freely in the adopted culture. While the novels of this chapter articulate a sense of a Britain which has changed internally with a large influx of migrant peoples from the former colonies, the Booker Prize winning novels discussed in the next chapter articulate the sense of unease, insularity and self-consciousness that characterises the British presence abroad especially after the Suez crisis in 1956.

\section{Notes}

${ }^{1}$ Bernice Rubens, The Elected Member (London, Hamish Hamilton: 1983), p. 47. All further quotations from this work are taken from this edition and are followed by the relevant page number in parenthesis.

${ }^{2}$ Shirley Kossick, "The Novels of Bernice Rubens: 1960-1992", Unisa English Studies $31: 2$ (1993), p. 35. 
${ }^{3}$ Stanley Middleton, Holiday (London: Penguin, 1974), p. 9. All further quotations from this work are taken from this edition and are followed by the relevant page number in parenthesis.

${ }^{4}$ David Storey, "Speaking of Writing II: David Storey", The Times 28 Nov. 1963, p. 15.

5John Russell Taylor, David Storey (Edinburgh: Longman, 1974), p. 3-4.

${ }^{6}$ Taylor, David Storey, p. 28.

${ }^{7}$ David Storey, Saville (London: Jonathan Cape, 1993), p. 178. All further quotations from this work are taken from this edition and are followed by the relevant page number in parenthesis.

8Janet Reinelt, "Storey's Novels and Plays: Fragile Fictions", in David Storey A Casebook, ed., W. Hutchings (New York: Garland, 1992), p. 55.

${ }^{9}$ Reinelt, "Storey's Novels and Plays: Fragile Fictions", p. 55.

${ }^{10}$ Suguna Ramanathan, Iris Murdoch. Figures of Good (London: Macmillan, 1990), p.2.

${ }^{11}$ Iris Murdoch, The Sea, The Sea (Frogmore: Triad/Panther Books, 1980), p.3. All further quotations from this work are taken from this edition and are followed by the relevant page number in parenthesis.

12Diana Brydon, "Re-writing the Tempest", World Literature Written in English 23:1 (1984), pp. 75-88.

${ }^{13}$ Lyndsey Tucker, "Released From Bands: Iris Murdoch's Two Prosperos in The Sea, The Sea", Contemporary Literature 27:3 (1986), p. 380.

14Tucker, "Released From Bands", p. 381.

${ }^{15}$ Buddhist religion and thought is here extrapolated from Ramanathan's Iris Murdoch. Figures of Good and Lyndsey Tucker's "Released From Bands: Iris Murdoch's Two Prosperos in The Sea, The Sea" (see above).

${ }^{16}$ General comments on contemporary British women writers are here expanded from Patricia Waugh's Feminine Fictions. Revisiting the Postmodern (London: Routledge, 1989). 
${ }^{17}$ Kathleen Wall, "The Remains of the Day and Its Challenges to Theories of Unreliable Narration", The Journal of Narrative Technique 24:1 (1994), p. 18.

${ }^{18}$ Kazuo Ishiguro, Remains of the Day (London: Faber and Faber, 1990), p. 12. All further quotations from this work are taken from this edition and are followed by the relevant page number in parenthesis.

${ }^{19}$ Wall, "The Remains of the Day ", pp. 22-23.

${ }^{20} \mathrm{M}$. Griffiths, "Great English Houses/New Homes In England?: Memory And Identity In Kazuo Ishiguro's The Remains Of The Day and V.S. Naipaul's The Enigma Of Arrival ", SPAN, Special Issue, 2. Oct. (1993), p. 489.

${ }^{21}$ Raymond Williams, The Country and the City (London: The Hogarth Press, 1993), p. 282.

${ }^{22}$ Timothy Brennan, "The National Longing For Form", in Nation and Narration, ed. Bhabha, Homi K. (London: Routledge, 1990), p. 57.

${ }^{23}$ Galen Strawson, "Tragically Disciplined and Dignified", Times Literary Supplement No. 4494 (1989), p. 535.

${ }^{24}$ Griffiths. "Great English Houses/New Homes In England?", p. 491.

${ }^{25}$ Strawson, "Tragically Disciplined and Dignified", p. 535.

${ }^{26}$ T.S. Eliot, "The Love Song of J. Alfred Prufrock", in Collected Poems 1909-1962 (London: Faber \& Faber, 1963), p. 13. v. 1. lines 1-12.

${ }^{27}$ T.S. Eliot, "Prufrock", p. 13. v. 5. lines 33-34.

${ }^{28}$ T.S. Eliot, "Prufrock", p. 16. v. 14. line 92.

${ }^{29}$ John Rex, "The Political Sociology of a Multi-Cultural Society", in Multiculturalism and the State, Volume 1 (London: University of London Institute of Commonwealth Studies, 1994), pp. 26-35. 


\section{Chapter Six}

The English Abroad

1. Excentricity and Eccentricities: The English Abroad

2. Crisis of Commonwealth: P.H. Newby's Something To Answer For, 1969

3. Between Land and Sea: Penelope Fitzgerald's Offshore, 1979

4. Continental Drift: Anita Brookner's Hotel Du Lac, 1984

5. Conclusion: Narratives of Insularity

\section{Excentricity and Eccentricities: The English Abroad}

By the late 1960s the British international presence was much depleted with Britain rapidly withdrawing from many of its colonies and protectorates- the decolonisation process had been largely accomplished. What had formerly been characterised as the spread of empire, the force of its expansion outward, was now in rapid reverse with a withdrawal into a decentred Britain. London continued to be a metropolitan city but was no longer the centre of global domination, and the Englishman abroad exemplified in early empire by figures such as that of the Duke of Wellington, the prototype of the new model gentleman, was no longer a character of unshakeable belief. Empire had shrunk and the British abroad resisted and embraced a variety of stereotypes characterised by both recalcitrance and eccentricity.

Formerly the epitome of "civilization" and moral fortitude, the hero of the Victorian era had by the 1950s metmorphosed into the anti-hero of P. H. Newby's Something To Answer For. Townrow is ingenuous and cheating, not without pluck and impervious to shame, but conniving and comicly irresolute. By comparison, the aura that surrounded the figure of Wellington, the ultimate "gentleman gbroad", especially in the years after his famous victory over Napolean at Waterloo was a curious mixture of elements- 
modernism, chivalry, patriotism, individualism, classicism, and xenophobia—summed up in the general quality of the British possessing "bottom". However, a hundred years later Britain was no longer the richest and most powerful nation in Europe and perhaps England's dominance was not only over but misplaced without figures like Cromwell, Marlborough, Nelson, and Wellington to inspire its peoples. ${ }^{1}$

The nineteenth century saw the growth of the "Great Man Cult" in which numerous biographies, portraits and statues portraying figures of merit were produced both of eminent men of the past and more recent heroes whose personalites could be portrayed as much as their deeds. It was from this lineage that the Victorian worship of self-discipline was derived-a quality distinctly lacking in P.H. Newby's anti-hero, Townrow and glimpsed in negative form by the prissyness of Edith Hope in Brookner's Hotel du Lac. Formerly associated with excentricity, with expansion to new frontiers, and with advancing moral values, Christianity and civilisation, Britain was by the $1950 \mathrm{~s}$ convalescent and reduced. A sense of entropy within Britain masked a process of cultural transformation and repatriation as the peoples of the former colonies gradually "colonised" Britain after the Second World War.

\section{Crisis of Commonwealth: P.H. Newby's Something to Answer For}

P. H. Newby was the first recipient of the Booker Prize in 1969 for his novel of a wayward British expatriate soldier, Townrow, in Egypt's Port Said at the time of the Suez crisis. In Something to Answer For, Newby concerns himself with the anxiety of the late British empire during the international crisis over the Suez Canal. This "anxiety" coincided with the recognition that Britain was no longer a super-power. Set ten years after the close of the Second World War, Newby's novel is concerned with British identity within an early post-colonial Egypt.' The era was one in which the British expatriates and colonials had "something to answer for."2

Newby satirises early imperial British rhetoric and the moral imperative of the Christian enlightenment project of bringing "civilisation" to the savage. Newby's 
expatriates are scattered, dislocated, and displaced. In many ways Something To Answer For is a humorous vehicle for the exposition of British cultural angst-a sense of guilt at the failure of a largely unself-critical imperialism.

Throughout the novel, Townrow, a frenetic and faintly scurrilous ex-soldier and confidence-man with a romantic imagination, attempts to retrieve his identity against the background of a changing Egypt. Townrow has misplaced his passport and cannot remember whether it reveals him to be English or Irish-and thus, he claims, neutral in Egypt. He embarks on a drunken and fevered odyssey amid the chaos of Port Said in 1956. The events take place around the impending Suez crisis, which saw the important shipping route nationalised under Nasser, and the British and French invasion in an attempt to wrest it from the Egyptian leader, under the watchful and ultimately foreboding eye of an all-powerful America during the era of the Cold War.

Each of the Commonwealth nations responded individually to the shock of the Suez crisis. As Peter Lyon points out in "The Commonwealth and the Suez Crisis": "There was no general consultation at a pan-Commonwealth level between July 1956 and July 1957, and little evidence of much general, mutual Commonwealth consultation without Britain-though doubtless, some informal, bilateral discussion took place. . . ." Subsequently, Anthony Eden, the then British Prime Minister, restricted the flow of information about the Suez crisis to the Commonwealth, ensuring that the British response would be established in secrecy. This buttressed the view that the Commonwealth was near the point of dissolution. After the crisis, however, and despite damage done to Britain's reputation at home and abroad, a programme of reconstituting the Commonwealth was put in place under the acting Prime Minister and then Harold Macmillan, who attempted to repair relations with the Commonwealth nations, by redressing the "comedy of Commonwealth non-events" as Lyon puts it and by spreading the message that British membership of the European Economic Community was complementary to, and not in opposition to, participation in the Commonwealth. ${ }^{3}$

By 1965, however, the nature of the Commonwealth organisation had changed with British decolonisation, and thus now reflected very much a global condition "after 
empire". The Suez affair was thus a psychological and political watershed which demonstrated Britain's willingness to reduce its proprietory rights in the Commonwealth organisation to facilitate entry into the European Community. It was a recognition both nationally and internationally that the days of empire were now well and truly over. As Lyon puts it:

Maybe the Suez episode principally showed that the Commonwealth as a whole was a craft only for collective fair-weather sailing, with little or no capacity to deal decisively with sudden storms and foul weather ... The Suez misadventure demonstrated unmistakably that Britain, by the mid-1950s, lacked sufficient financial and military strength and will to maintain a masterful policy. Amidst the volatilities of the Middle East and with the Americans nibbling or gnawing away at their erstwhile local monopolies more and more, the one-time familiar British benefits of power-privileges on the cheap could no longer be secured. . . . The Suez misadventure hastened and advertised the well nigh inevitable end of Britain's imperial statehood. In the Middle East, after 1956, there would be no post-imperial Commonwealth camouflage to provide some semblance of posthumous vindication for empire or to ease the transition to an era when some local leaders would be able to assume active world roles regardless of whether Britain wished to act as their patron or guardian. ${ }^{4}$

Newby's novel concerns itself with this fraught socio-political arena. Newby had received the Somerset Maugham Prize in 1948 for his first novel A Journey into the Interior. First published in 1945, this novel was based on a romanticised Egypt. After the outbreak of the Second World War, Newby, who had been a teacher, was shipped first to France and then shortly after to Egypt, where in 1942 he was seconded from the army to become a lecturer in English at Fouad Awal University in Cairo, where he 
remained until 1946. The experience of Egypt was to have a pervasive influence over Newby's writing, both thematically and stylistically (in the interim he had written novels set in both England and Wales, and also England and Egypt).

As with the misadventures of the drunken consul of Malcolm Lowry's Under the Volcano (1947) who represents the erratic decline of empire, there is a metaphysical underpinning to Townrow's lurid Port Said wanderings-a kind of vacillation between self-denial and nihilism, a cultural angst which reflects something of the incipient "guilt" of empire. Like the consul, Townrow exhibits a carefree hedonism that sees Townrow apolitical, internationalist, and apparently uncommitted in the face of international political turmoil. As Townrow reveals in the context of the charity fund which he is paid to redistribute among its donors, and which he in fact milks by forging receipts, again in parody of the dissolution of empire and colonialism: "That was between him and his shadow"(8).

While at the airport enroute to Port Said, Townrow is exposed to the antipathy toward the British empire. He is drawn into conversation with an Israeli and a Greek concerning treatment of the Jews in the Second World War and the responsibility and implied complicity on the part of the British for not directly hindering their extermination by the Nazis, a theme which is also in part raised by the 1982 Booker Prize winner, Thomas Keneally's Schindler's Ark. As the Israeli, who was interned in a labour camp, explains to Townrow, who despite himself absorbs some of the Israeli's statement: "'We all listen. We sit in the dark, and so I sat in the dark with my father and my uncle. At no time, I tell you, did the B.B.C. warn us about those trains. It is useless to deny it. Why was there no warning? We Jews did not know. . . This was British Government policy. What other explanation could there be? The British Government connived. What are the Jews of Europe to the British?'" (13-14)

Townrow, while not a British patriot, is somewhat taken aback by the vehemence of the Israeli's statement. He refuses to believe that the British government is "like that". He thinks naively that the system simply wouldn't allow it. The Greek asserts from his experiences that the English are not a grateful people. He also asserts that the peoples of 
many countries believe their governments to be corrupt-except that it is the British who cling self-defensively to their government as an embodiment of the institution of empire (however reduced) within the context of international affairs:

The Englishman ... thinks he is good and sincere himself and he believes he has a government that is good and sincere too. I don't care whether it's a Labour Government or a Conservative Government. He may disagree with it but he does not think it is corrupt. This is what he understands about life. Every Englishman, when he is abroad, feels he can speak authoritatively for Whitehall. An illusion. They think, in Britain, that private life and public policy is one seamless garment. Every country has its special illusion. This is the British illusion (16).

Thus Newby in part concerns himself with exploding the "myth" of the British character associated with the "gentleman abroad." The "special illusion" of the British nation that "private life and public policy is one seamless garment" in Something To Answer For reveals the garments of a dishevelled empire.

While in some senses Townrow explodes the myth of the "gentleman abroad", he is nevertheless a walking example of the hypocrisy of imperial rhetoric. Townrow is a manipulator who claims the "trust" of British culture, a trust which he neither feels nor demonstrates, but merely re-invents, given the "spectre" of the cultural "Other": "In the U.K. you trusted people. In the main you took it for granted people acted decently. You made an assumption about the man who sat next to you in the tube. You didn't know for sure. You just assumed. Well, if you didn't make assumptions like that how could you trust the government? Townrow wanted to tell Mrs K that trust in big things started with personal relations ..." (43)

Townrow is torn between a desire to be selfishly irresponsible and a sense of patriotic duty. His identity is established between these two characteristics, the one a more genuine expression and the other hypocritical, unauthentic--perhaps mirroring the 
hypocrisy of a British nationhood torn between guilt in the wake of empire and selfconcern in turning away from a fragmenting Commonwealth toward the collective security of the EEC. His vagueness and hedonism are flights into a post-colonial dislocation from which he in turn eventually flees.

The British invasion of Egypt in order to attempt to take back the Canal, and the setbacks that take place, are signalled by Townrow's wavering lucidity, and confused ineffectiveness (again like Lowry's drunken consul). Townrow's mental state mirrors the hesitant nature of the British in international affairs, the waning influence of the once all-powerful British empire: "I'm ashamed of being British. Why start an invasion if you don't mean to go through with it? Why stop when you've got as far as this? I'11 tell you what, we British have lost our nerve. People of my father's generation wouldn't have lost their nerve" (260). Ultimately Townrow, Leah, and Mrs $\mathrm{K}$ flee the Canal zone in a small boat accompanied by Elie's coffin, which Townrow has exhumed with the help of some troops. This scene dissolves into one which is symptomatic of a larger, almost metaphysical, dislocation. Townrow is left in a tiny boat, rowing out into the ocean, the others being picked up by a larger sailing vessel, amid a flotilla of large boats. It is as if he represents empire in retreat. All Townrow desires at this point is solitude. His trust in the familiar English social codes now completely dismissed, he is thrown back entirely on his own resources; cast adrift, he becomes the wandering internationalist that a residual loyalty to the notion of empire had prevented him from becoming: "[h]e now knew he could not afford to surrender the smallest splinter of judgement to any government, organisation, cause or campaign. He was to trust only immediate promptings, what the eye saw, the nose smelled, the hand touched ... He knew by a sense of absence, he had arrived. He was away and alone, stark" (285).

While not one of Britain's Angry Young Men, Newby has something in common with the comic realism of Kingsley Amis. Like Roger Micheldene, the Englishman in America in One Fat Englishman, Townrow is a variation of the post-imperial expatriate English figure, cutting not-quite-a-dash within the changed environs of a foreign culture. 
Townrow personifies the confusion of identity in the wake of a dissolving British presence in Egypt; the uncertainties, the frenetic ambiguities, the xenophobia in the presence of racial intermingling, and the renegotiation of social codes and practices which typify the English presence on post-colonial soil. Newby's portrayal of late-modern dislocation has the quality of disjunctiveness of Malcolm Lowry, who in Ultramarine (1933) and Under The Volcano conveys the sense of a modernist fragmentation of the English presence in the areas of British colonial domination. In Newby's Townrow there is the nihilism, the self-abandonment with attendant guilt of Lowry's drunken consul, Geoffrey Firmin.

The Suez crisis was a "psychological watershed" in British history. It brought both national and international recognition of the dissolution of empire and Britain's withdrawal from a largely honorific Commonwealth, together with a growing awareness of Britain as a diminished presence in Europe and as an increasingly a second-rate international power behind the United States and the Soviet Union. As Townrow escapes from Port Said in his one-man boat, shipping water, he represents the retreat of empire in the face of a surprising and effective Egyptian nationalism, the nationalism of the former colonised "Other", and a retreat to the embrace of the European community. The "something to answer for" of Newby's novel is the guilt of a retreat from empire that reveals the spectre of British identity in the wake of decolonisation: a guilt not only associated with deeds done and now regretted, but also with deeds not done, of what is left behind in the wake of the British and which the decolonising projects seek to redress.

\section{Between Land and Sea: Penelope Fitzgerald's Offshore}

At face value it seems difficult to reconcile the 1960s Thames world of Penelope Fitzgerald's Offshore with Joseph Conrad's Heart of Darkness (1899), a seminal story of nineteenth-century colonialism. Nevertheless, Offshore carries an echo of Conrad. As Edward Said puts it: "Recall once again that Conrad sets the story on the deck of a boat anchored in the Thames; as Marlow tells the story the sun sets, and by the end of the 
narrative the heart of darkness has reappeared in England; outside the group of Marlow's listeners lies an undefined and unclear world." 5 It is as if a shadow of Conrad's "darkness" has enveloped the indeterminant tidal world of Fitzgerald's Offshore protagonists. The "undefined and unclear world" of Offshore is representative of an "empire" and colonies that see themselves as neither fully tied nor fully affiliated to an imperial centre. It suggests an ambivalent mediation between the metaphor of country and city. Fitzgerald's novel gently portrays an offshore world of faded maritime grandeur and imperial entropy that in atmosphere and theme carries a suggestion of the spectre of otherness or the indeterminacy of self at or near the geographical "centre" of contemporary British cosmopolitanism.

Like Anita Brookner's Hotel du Lac, Penelope Fitzgerald's Offshore, which won the Booker in 1979, is a relatively short novel. Like Brookner, Fitzgerald is a British novelist who does not fit easily into any one category. She is the author of two biographical works, Edward Burne-Jones: A Biography (1975) and The Knox Brothers (1977) and did not begin publishing fiction until 1977, at the age of sixty. Both her biographies and her subsequent fiction have been popularly and critically acclaimed. She has written two novels which have been shortlisted for the Booker Prize, The Bookshop (1989) and The Beginning of Spring (1988).

Fitzgerald has held various jobs, from bookseller, journalist, teacher, to working for the BBC during the Second World War. She studied English Literature at Oxford in the late 1930s. The setting for her novels, usually based on workplaces, is frequently in part derived from autobiographical experience. Fitzgerald lived on a Thames barge houseboat while bringing up her young family, and this experience is reflected in Offshore.

Offshore, like Hotel du Lac, is written with a graceful economy of style. It weaves a subtle and humanly complex story of a houseboat community who live between the land and water of the London Battersea Reach of the 1960s. The novel combines both humour and seriousness in its evocative depiction of the interactions of the houseboat dwellers as they live their lives on the Thames. 
Like Edith in Brookner's Hotel du Lac, the protagonists of Offshore choose to lead lives on the periphery of society. This periphery is defined not so much in an overt social sense as with Edith's paradoxical "romantic" feminism, but literally as living between water and land, as if in a constant ambivalent state between arrival and departure. The houseboat dwellers feel they do not wholly belong to either world. Their Battersea Reach community is one without centre, a tidal world characterised by eccentricity. As such, Fitzergerald's novel depicts an entropic late-twentieth century British society in microcosm. Lively's characters dream of living on land, or of putting to sea, but are rarely satisfied with their offshore current of either life. While her characters are exiles they are not fully exiled. Like England's ties with Europe, they are tied to the land, yet float apart from it.

Offshore is not directly a novel of nostalgia, of longing for a centre lost; it is one, however, of British rootlessness. The intertextual echoes are of the Dickensian world of Our Mutual Friend (1865) and T.S. Eliot's The Waste Land (1922). Humour is mixed with pathos, catharsis and reclamation, as the lives of the barge owners intermingle in the etiolated light of a faded and sometimes gently pretentious imperial maritime grandeur:

The barge-dwellers, creatures neither of firm land nor water, would have liked to be more respectable than they were. They aspired towards the Chelsea shore, where, in the early 1960's, many thousands lived with their sensible occupations and adequate amounts of money. But a certain failure, distressing to themselves, to be like other people, caused them to sink back, with so much else that drifted or was washed up, into the mud moorings of the tideway. ${ }^{6}$

The boats that populate Fitzgerald's "offshore" world have names that are the echoes of a grand imperial maritime and naval era intermingled with the literary, whimsical and mundane: Rochester, Grace, Bluebird, Maurice, Hours of Ease, Dunkirk, Relentless, Lord Jim, Dreadnought. Conrad, Austen, and Forster and the author's own craft are 
invoked in a context of dishevelled parody and juxtaposed with references to grand naval ships and battles. The texts of imperialism and colonialism are re-floated in miniature, emblematic of an empire now reduced, parodically invoked on the Battersea Reaches. Fitzgerald's novel depicts a floating world in distillation and echoes an era past, in its cast of misfits and middle-class mutineers who share a common identity and code of their own in their offshore community: "[t]hey were not easily dislodged. But to sell your craft, to leave the Reach, was felt to be a desperate step, like those of the amphibians when, in earlier stages of the world's history, they took to ground. Many of the species perished in the attempt." (10)

The Victorianism of Dickens' London is invoked in the context of a remembrance of a Darwinian thematic intrusion in the essentially Christian narrative of the novel. The world of Offshore is like the Thames world of Lizzie and Gaffer Hexam in Dickens' Our Mutual Friend (1864-5) who scoop a living from the Thames by reclamation-rescuing things of value, and retrieving coins from the pockets of the drowned (much like Nenna's children in Offshore). At more than one point the atmospheric intertextuality collides and Dickens' novel of spiritual and material reclamation is clearly invoked in Fitzgerald's: "[i]f the old Thames trades had still persisted, if boatmen had still made a living from taking the coins from the pockets of the drowned, then this was the hour for them to watch." (26); and subsequently the elderly Willis, invoking his father in a passage of almost grotesque revery: "[1]ong had he studied the secrets of the Thames. None but he would have noticed the gleam of gold and diamonds-the ring on the dead man's finger as his hand broke the surface. Farewell!" (28)

Offshore tells of the entwined lives of its houseboat neighbours. The novel is populated by characters such as Richard, a correct and practical ex-RNVR city man, who "can make things work" and who presides over the community in Lord Jim like an unofficial mayor; his wife, Laura, who is less impressed with their houseboat life; Maurice, a male prostitute to whom all turn as confidant and for company; Nenna separated from her "clerical" husband, Edward, whose young children run wild on the foreshore and nearby streets of the river; and Willis, a maritime painter, who has never 
been to sea. The lives of all Fitzgerald's protagonists are to some extent disrupted, their relationships unsettled; the novel concerns itself with their interactions and invokes their personal relationships against their "tidal" lives on the "crazy old vessels" of the Thames (13): "Was there not, on the whole of Battersea Reach, a couple, married or unmarried, living together in the ordinary way?" (68)

Fitzgerald's strength is her ability to invoke an authenticity of character and atmosphere. Her understatement is achieved without the judicious irony of, for example, the Victorian novelists of morality. When the homosexual, Maurice, places an old street lamp on his deck fitted with sheets of mauve plastic casting a half brightly purple shadow of this boat and environs because it makes him think of the Venice he has glimpsed in postcards, the reader is sympathetic to Maurice's sensibilities and the ironic invocation on the offshore Thames of a light "suggesting an amateur production of Tales of Hoffinan." (42) Likewise, Nenna and her children are variously entranced: "'T've always wanted to see Venice, almost more than any other place. I was only wondering what would happen when the wind gets up.'" (43) Maurice and Nenna are confidants, they share a complicity in their unconventionality, and a joy in a shared sensibility of the hidden qualities of their houseboat lives: "at flood tide they saw the river as a powerful god, bearded with the white foam of detergents, calling home the twenty-seven lost rivers of London, sighing as the night declined." (45) Maurice himself describes the lives of the community as "half" lives-marginalised lives. Fitzgerald's offshore community is composed of people who are defined by their indeterminacy. Whereas for Maurice this is a kind of acceptance, for Nenna (who has the responsibility of children) it is a concern to which she is not fully reconciled: "[i]t's right for us to live where we do, between land and water. You, my dear, you're half in love with your husband, then there's Martha who's half a child and half a girl, Richard who can't give up half being in the Navy, Willis who's half an artist and half a longshoreman, a cat who's half alive and half dead . .." (47) Ultimately Nenna and children leave for a new life in Canada. Richard, after his wife leaves him, has a brief affair ("ships that passed in the night") with Nenna, and is later knocked unconscious and hospitalised by one of Maurice's criminal 
acquaintances. Both Lord Jim and Grace are put for sale on Pinkie's books (recalling the character from Graham Greene's Brighton Rock (1938)). A final storm hits Battersea Reach and the Thames swells as the westerly wind is combined with a high tide, rats behave strangely, the Embankment is swept clean, the wind flings missiles around boats and buildings, and as the boats begin to roll as if at sea, Maurice's anchor wrenches free of the mud, and Maurice and Edward, Nenna's estranged and now jealous and drunken husband, put out with the tide.

Fitzgerald's novel is low-key, understated, a porthole on an alternative London community that is at once independent and free-spirited yet caught between shore and sea, its members marginalised by their unconventional relationships and uncomfortable with the social structure of life on land. The offshore community of Fitzgerald's novel is composed of non-conformists. Their society is a "peripheral", half-light society of eccentrics, their lives interconnected by shared grievances and a suppressed recognition of their mutual eccentricities. Offshore portrays a community ill at ease with the legacy of empire, uncomfortable with the conventions of contemporary English society, and

surrounded by the iconography of decline, romantically yearning after the days of imperial gradeur on the high seas. As with the Raj novels of Paul Scott, Offshore takes an affectionate and nostalgic glance at the decline of empire and highlights the resistance to entropy and neglect at the fringes of contemporary "English" Britain.

\section{Continental Drift: Anita Brookner's Hotel Du Lac}

Anita Brookner's 1984 Booker Prize winning Hotel Du Lac reflects something of the collapse of confidence and insularity of Britain in post-war contemporary Europe. Brookner's protagonist, Edith Hope, is in many ways the product of a British middleclass insularity. The novel succeeds in so far as with the elegance of a line-drawing it delineates the nature of this insularity and extends a narrative sympathy to Edith whose anxieties are played out against the backdrop of a British "convalescence" within Europe. 
The sparse and elegant tone of Hotel du Lac invokes comparison with painting and drawing. As well as this minimalist delineative precision there is a strongly anthropomorphic quality in the text whereby the physical world of the Hotel du Lac corresponds to Edith's own mental world. Barbara Hardy has described the novel as being "as amiable as the heroine, though its charm seems drier."7

It is easy to underestimate Hotel du Lac. What seems on the surface to be a simple story of the frustrated love-life of a middle-class English writer, in fact reveals a complex set of interrelations between the nature of writing, art, and a middle-class English (feminine and) feminist consciousness. In the novel this consciousness is both inhibited and defined in terms of the intertextuality of its literary inheritance, be that romantic or more overtly literary in aspiration. The text works so as to juxtapose romantic longing (and the genre of romantic longing, such as the Barbara Cartland-like titles of Edith [Vanessa Wilde's] works The Stone and the Star and Le Soleil de Minuit ) with a narrative of clinical detachment and observation.

Hotel du Lac holds a mirror up to the kind of insular middle-class Englishness that both promotes and suppresses the notion of female romantic longing. The novel is set on the continent, a Swiss lakeside hotel, in which Edith's solitude is emphasised by the hushed conservatism of her surroundings. The lake provides a backdrop against which Edith's own drabness is accentuated also as a kind of exoticism, a parody of the Mills and Boon style of popular fictional excess: "The scenery, the view, the mountain, were curiously unemphatic, as if delineated in the water-colours of an earlier period" (15). Hotel $d u$ Lac offers a kind of convalescence for Edith who is staying at the hotel to recover from a doomed affair with a married art dealer. Edith is to some extent a victim of her own genre, itself a legacy of a suppressed sexuality implicit in the Victorian novel of manners. Brookner rescues a kind of dignity for the contemporary female novel of romance. This is a world in which ordering a cup of coffee can be an action of "Nietzschean directness". (99)

In Hotel du Lac Edith's mental landscape is projected onto her immediate environment. The words and phrases "stiffish leaves" "unfamiliar plant", "anaesthetic", 
"invisible shore", "out of season", "uncommunicative", "taciturn", "gaunt remains" provide an insight into Edith's mental sterility and paint her as a figure of etiolation or of eclipse against the light of the inquisitive narrative. From the outset we know that she is attempting to recuperate, we know that she looks like Virginia Woolf, that she likes the concept of "home", that she is a "dutiful" writer, "a good plain cook", she has a "trusting personality", a "low profile", and that her "curative stay in grey solitude" at the suggestion of "friends" keeps her away from resuming her "peaceable existence".

Edith's self-professedly dull life is contrasted with the romantic fiction that she writes. In the course of the novel she writes more romantic fictions: the beginnings of her next novel, Beneath the Visiting Moon, and a series of letters to her former lover, David (her relationship with whom she is ostensibly recuperating from). Edith attempts to come to terms with the disparity between her two inner fictional romantic lives. The letter itself reads like the fiction the reader is led to believe Edith writes, which is all the more ironic as we know that it carries a genuine emotional meaning for her. The letter is a fiction, but not quite the fiction of her novels, nor necessarily the fiction of Brookner's text, Hotel du Lac.

What the hotel itself has to offer Edith is "a mild form of sanctuary, an assurance of privacy, and the protection and the discretion that attach themselves to blamelessness" (14). However, the issue of Edith's blamelessness is not raised in the novel. For Brookner, all lovers are seemingly victims of their love, just as all lonelinesses are equal. The hotel itself acts as a house of fictions or a canvas for Brookner's metafiction. The lake provides an intertextual pool of literary reflections: including Woolf, Pym, Shakespeare, Mills and Boon, Drabble, Henry James, Edith Wharton, Austen, Eliot, Flaubert, Honore de Balzac, and even Francoise Sagan.

Edith's holiday on the Continent portrays a very British middle-class lonely female entrapment in either a loveless marriage, doomed passion, or in eternal loneliness. Part of the cause of this entrapment is an artificially imposed morality derived from the fictions and social codes of a pervasive Victorianism. As Gisele Marie Baxter points out: "this deliberate anachronism robs [Brookner's protagonists] of effective manipulative skills, 
yet contributes to the fascination with a class-specific "Englishness" that determines their choice of cultural experiences . . Brookner explores her protagonists' dislocation and reveals their self-definition and capacity for delusion chiefly through three cultural phenomena: apparel and physical presentation, relationships with men, and texts used as guides, or; clothes, men and books." 9

Edith is thus clothed or constructed by both external and internal representations. She is conservatively dressed in her "Liberty silk smock" and "plain kid pumps". (24) She is demure and self-deprecatory and self-conscious in public. Her choice of attire reflects her awkwardness and reticence. Even when she does "dress up" and changes her hairstyle it is not to mark a social assertiveness but to renew the habitual routine of writing and dinner. She willingly accepts social relationships, like that with the "glamorous" bourgeois mother and daughter entourage of the Puseys, in which she trades patronage for the semblance of company and friendship. As Patricia Waugh points out, she is caught in the conflict of the need for autonomy and the need for social connection. ${ }^{10} \mathrm{Mrs}$ Pusey, ironically, is not reminded by Edith of Virginia Woolf but of Princess Anne. The overt adoption of the Virginia Woolf persona, suggested by Brookner as a literary and cultural icon as much as for a true personal reflection of Edith, accentuates her loneliness and confines her to a privacy in which she is both comfortable and frustrated. It also hides Edith within a stereotype which she both confirms and denies. She is vindicated in the text by what Baxter calls a "genuinely Bloomsburian freedom of spirit" 11 which allows her to reject Mr Neville's offer of a platonic and sexually faithless marriage, and permits her a genuine release into social unacceptability and reclusiveness, fuelled as it is by the desire to remain true to a caricature of a literary feminine type. Again, as Baxter points out:

Brookner's protagonists differ from their popular-romance counterparts in that their guilessness is not innocence. They are marginalized as much by their own sense of moral identity as by the aspects of gender and culture that inform that identity. Brookner 
represents their social position (and their perception of it) through various forms of cultural iconography, particularly English. By Hotel du Lac, she suggests that strength and self-awareness are found not so much in finding access to the inner circle, as in recognizing why you are on the periphery. ${ }^{12}$

The post-modernism of the Hotel $d u$ Lac, mainly evidenced in its metafictional qualities and an intertextual pool of references involving contemporary modern and Victorian (women's) fiction, is significant in view of its juxtaposition with issues of feminism. Edith's loneliness equates to her inability to find a stable sense of subjectivity. As Waugh points out, the post-modern exhaustion of the existential belief in selfpresence and a dispersal of the universal subject of liberalism, or a liberal feminism of kind embodied in the character of Mrs Ramsey in Woolf's To The Lighthouse, is resisted by contemporary feminist literature. As she puts it:

women writers are beginning, for the first time in history, to construct an identity out of the recognition that women need to discover, and must fight for, a sense of unified selfhood, a rational, coherent, effective identity. As male writers lament its demise, women writers have not yet experienced that subjectivity which will give them a sense of personal autonomy, continuous identity, a history or agency in the world. ${ }^{13}$

Edith, of course, does not quite fit the feminist mould in this respect; she desires a stable identity of her own, but finds it, ironically, on the periphery of society, and by reconciling herself to the self-marginalisation that allows her to keep her autonomy and which fuels her desire to construct her worlds of fictional romance. She constructs her real-life identity around the cultural icon of Virginia Woolf, and in many ways she explores in this the qualities of identity that Waugh sees as being embodied in Woolf's writing: "Woolf seeks to become aware of the paralysing and alienating determinations of 
the myth of Woman, but equally to avoid embracing an identity articulated through an ideal of contained, coherent, "proportioned" subjectivity which for her expressed the dominant cultural norm of masculinity." 14 In her portrayal of Edith in this manner-her insularity and high romance-she is able to both vindicate and parody Woolf. Throughout Hotel du Lac, Edith claims to be domestic and unromantic and yet she has little sympathy for either the ultra-feminine or feminism.

Edith represents a reduced feminine version of the "Englishman abroad", no longer confident and judgemental but inhibited and timid. She represents a middle-class England which consumes images and conventions of its own cultural past. Edith's Woolfian mask is a persona for the modern female novelist; Hotel du Lac a critique of the apparatus that produces the contemporary female novel of romantic longing. The legacy of empire in Hotel du Lac is signified by the nostalgia of romantic adventure associated with the spread of empire, a nostagia that can only be experienced second hand in the ironic and self-consuming culture of its aftermath.

\section{Conclusion: Narratives of Insularity}

Something To Answer For, Offshore, and Hotel du Lac are all narratives that reflect British insularity following the break up of empire and the two world wars in Europe. The protagonists in these novels, from P.H. Newby's Townrow to Anita Brookner's Edith Hope, reflect a lack confidence in the British character abroad, a confidence that was once an accepted norm, a prerogative of empire. They reflect an inward-looking Britain retrenching its colonies and protectorates and attempting to consolidate the loss of empire with a more modest focus of its affairs in Europe and the EEC.

P.H. Newby's Something To Answer For, the first Booker winner and one which explores the loss of imperial power, is a novel which concerns itself with the Suez Canal crisis at Port Said at mid-century. Its protagonist, Townrow, is a wayward expatriate exsoldier who negotiates his way scurrulously through the disparate population of the Egyptian Port at the time of the crisis that was brought about by Nasser's nationalisation of the Canal and the British military response. Townrow is an anti-hero. He parodically 
represents the undermining of the character of the English gentleman abroad, and Newby's novel is a humorous recognition of Britain's waning influence in international affairs, the scattering of empire into a crowded and unruly collection of disparate nations and groups. The waning of empire is explored through the tragi-comic affairs of Townrow in turbulent post-colonial Egypt.

The theme of entropy is continued in Penelope Fitzgerald's Offshore, a semiautobiographical account of a river-boat community who live in houseboats moored on London's Battersea Reaches. This gathering of misfits, dwelling neither on land nor fully at sea, represents an insular community of resistance to the urban and suburban sprawl of London. They are an eccentric and marginalised group who are happily disengaged from the society for which they have a comic distrust. The protagonists of Offshore live in a kind of exile, the extent and nature of which, and their commitment to which, are not quite certain. They choose to lead lives on the periphery of society. This periphery is defined not so much in an overt social sense but literally as living between water and land, as if in a constant state of either arrival or departure, they feel they do not wholly belong to either. Their world again is one of a British restlessness, a tidal world characterised by its very indeterminacy. As such Fitzergerald's novel depicts British society in microcosm. Lively's characters dream of living on land, or putting to sea, but are rarely satisfied with their offshore current of either life. While they are exiles, they are not fully exiled. They are tied to the land, yet float apart from it.

In Anita Brookner's Hotel du Lac, Edith Hope, the novel's middle-aged unmarried writer of romantic love stories, is convalescing in a Swiss hotel by a lake after an unhappy love affair. In Edith a soft parody is invoked of the genre of female romance counterpointed by Edith's modernist Woolfian mask. Feminist and female fiction are thus juxtaposed in the character of Edith, who finds a moral strength in remaining true to her profession at the expense of a proposed marriage of middle-class pretence. The Victorian qualities of Edith, who at one point is likened to Princess Anne, become an etiolated mirror of a depleted British imperial character. In Hotel du Lac, the British presence through Edith is portrayed as retaining an inner moral strength while ostensibly enjoying 
a "continental convalescence". A further group of Booker Prize winning novels, the "post-imperials", explore Britishness from the perspective of new nationalisms in the former United Kingdom. These articulate the cultural differences between contemporary Ireland, Scotland, and Wales and are discussed in the next chapter.

\section{Notes}

${ }^{1}$ Iain Pears, "The Gentleman and the Hero: Wellington and Napoleon in the Nineteenth Century" in Myths of the English, ed., Porter, R .(Cambridge: Polity, 1992), p. 216218.

2P.H. Newby, Something To Answer For (Guernsey: Palm Books, 1993). All further quotations from this work are taken from this edition and are followed by the relevant page number in parenthesis.

${ }^{3}$ Peter Lyon, "The Commonwealth and the Suez Crisis" in Suez 1956. The Crisis and its Consequences, eds., Louis, R \& Owen, R (Oxford: Oxford University Press, 1989), p. 267.

${ }^{4}$ Lyon "The Commonwealth and the Suez Crisis", p. 273.

5Edward Said, Culture and Imperialism (London: Vintage, 1994), p. 28.

6Penelope Fitzgerald, Offshore (London: Collins, 1979), p. 10. All further quotations from this work are taken from this edition and are followed by the relevant page number in parenthesis.

${ }^{7}$ Barbara Hardy, "A Cinderella's Loneliness", Times Literary Supplement. 14 Sept. 1984, p. 1019.

${ }^{8}$ Anita Brookner, Hotel du Lac (London: Triad/Panther, 1984), p. 8. All further quotations from this work are taken from this edition and are followed by the relevant page number in parenthesis.

${ }^{9}$ Gisele M. Baxter, "Clothes, Men and Books: Cultural Experiences and Identity in the Early Novels of Anita Brookner", English 42:173 (1993), p. 126. 
${ }^{10}$ Patricia Waugh, Feminine Fictions. Revisiting the Postmodern (London: New York: Routledge, 1989), p. 140.

11Baxter, "Clothes, Men and Books", p. 135.

12Baxter, "Clothes, Men and Books", p. 137.

${ }^{13}$ Waugh, Feminine Fictions, p. 6.

${ }^{14}$ Waugh, Feminine Fictions, p. 10. 


\section{Chapter Seven \\ "Post-imperials": The British Post-colonials}

1. The British and the New Britain

2. Fakes and Originals: Kingsley Amis's The Old Devils, 1986

3. Towards an Irish Literary Post-modernism: Roddy Doyle's Paddy

Clarke Ha Ha Ha, 1993

4. Grim and Demotic: James Kelman's How Late It Was, How Late, 1994

5. "Post-Imperials": The British Post-colonials

\section{The British and the New Britain}

A group of recent Booker Prize winners share a common theme in exploring the rise of ethnic or British "tribal" nationalisms following the dissolution of empire. The Old Devils, Paddy Clarke Ha Ha Ha and How Late It Was, How Late seek, albeit sceptically, a recourse to various Celtic mythologies, for the re-discovery, often through everyday narrative and demotic language, of supposedly authentic separate British cultures at source. This occurred as the United Kingdom ceased to be properly united in 1922 when Ireland acquired its own political identity. Since then there has been a gradual rise in separatist movements in Scotland (with the establishment of the independent Scottish Parliament by referendum in 1997) and (less determinedly) in Wales. As Tony Blair's new Labour government came to power in 1996, Britain became more overtly multicultural with strong ethnic differences being celebrated among its populace in the spirit of the election victory. Being British no longer means being one of the English, Irish, Scots, or Welsh but expressing an identity among many ethnic groups that live in Great Britain. Perhaps, however, a wider sense of a multicultural British people is about to emerge from the stereotypical base of a predominantly Anglo-Celtic British phase that the novels in this chapter serve to establish. The novels discussed in this chapter register 
separate strains of nationalism emerging within Britain They articulate a sense of independent British nationalisms in the post-imperial era which no longer have the common link in identity of a share in empire.

Kingsley Amis's concern in The Old Devils is with relationships played out against a backdrop of a Wales characterised by a cultural superficiality. The Old Devils evokes a cultural bankruptcy, a nostalgic memory of an authentic Wales that never really existed, a pastiche in the present of a distillation of Celtic meanings. The authenticity of emotional lives of its protagonists is paralleled with the inauthenticity of the contemporary Welsh culture industry, satirised by Amis's comic wit.

Paddy Clarke is set in the fictitious working-class suburb of Barrytown, and the novel deals with growing up in suburban contemporary Ireland. Roddy Doyle's fiction is characterised by a prodigious humour and finely attuned sense of dialogue. Like most successful comedies, Paddy Clarke has an undertone of serious social commentary but, unusually, the ostensibly light and engaging narrative also contains an element of pathos that makes this comedy of the commonplace all the more acute.

Dark and sardonic humour forms the basis of Kelman's 1994 Booker Prize winning novel of Glaswegian under-class adversity, How Late It Was, How Late. Blackly comic, Kelman's novel is written in realist mode similar to that of Irishman Dermot Bolger. In How Late It Was, How Late Kelman explores urban myth and human determination. His novel is at once demotic epic, regionalist-realist bathos, black-satire, fierce political and social comment, and post-modern urban indictment; Sammy is at once a victim, everyman, and urban anti-hero.

Each of these novels, then, evokes something of Celtic revival. Each deals explicitly with British nationalisms after-empire, and implicitly with themes of authenticity, change, and identity, speaking for both established and underground voices in contemporary British, Scots, and Irish culture and identity. They represent the distinct literary character of the separate nationalisms of the former United Kingdom and anticipate (and to some extent both promote and resist) the ethnic and cultural diversity of the the "New Britain" of the $1990 \mathrm{~s}$. 


\section{Fakes and Originals: Kingsley Amis's The Old Devils}

"We need a few fakes to put a dent in all that bloody authenticity." Kingsley Amis, The Old Devils 1

Wales was united and annexed with England in 1536 so that all Welshmen enjoyed citizenship on the same terms as Englishmen. Although the official language became English, the object in the sixteenth century was to provide unity of administration rather than abolition of the Welsh language. Prior to this, Wales was independent of England with its own form of unity, language and folklore. The political independence of parts of Wales was dissolved in the twelfth and thirteenth centuries with Norman and English conquest. The Welsh sense of nationhood has not derived from political independence over the last five centuries but from the Welsh language. This is the language of religion and fosters a sense of the folk memory of the nation as a custodian of tradition with bards providing an enduring sense of a separate Welsh myth and reality. The idea of an elected Welsh assembly was rejected in 1979.

What is authentic and original in culture, and what is authentic in emotional, written and spoken lives become the underlying themes of Amis's contemporary Welsh comedy which feeds on the nostalgia for Welsh independence. Alun and Rhiannon's coming home after an absence of forty years during which time Alun has forged a career with the British media and $\mathrm{BBC}$ based on matters Welsh, articulates also a form of self-satire of Amis as an ageing British novelist—one of the "Angry Young Men" thirty years on. This is a world in which human frailties are traded under the largesse of mutual acceptance. Alun-famous, shallow, engaging, faithless, fun-loving, devilish-is the source of the novel's vitality and acts as a catalyst to a re-awoken sense of venomous fun among the husbands and wives of the novel's circle. Like the literary Amis, Alun is incorrigible and grumpy, with a comic petulance that simultaneously bolsters and pokes fun at his erstwhile acquaintances and their ageing middle-class society. As Barbara Everett expands on the novel in "Kingsley Amis: Devils and Others": 
One of the book's major themes is the very loss of national and racial identity: Welsh and Welshness, it is said, hardly 'exist' now except as a form of charlatanism, or a bane. Yet, just as this lament has its own moral counterpoise - what the individual does not find outside himself, he must find inside-so it offers a clue to certain of Amis's aesthetic methods. In The Old Devils, uncertainty about Wales and Welshness, and indeed about the whole characterisation of individuals, can act more as a positive than a negative, and lead the attention to where the book has its real strength and character. Amis is concerned here, as he has mostly been (and as the whole novel genre has usually been, insofar as it is a social medium), with love and friendship ...2

The novel develops according to a naturalistic pattern of social encounters which are predominantly, with the exception of the novel's double climax, relations between the more or less equal protagonists of the story. As Blake Morrison puts it: "Since the five couples drink together-or, rather, drink separately, the men in their pub, "The Bible", the women at home--knowledge or ignorance of these weavings adds tension to a plot which threatens to do no more than crawl from one pub to the next."3

From the outset the rumoured return of Alun and Rhiannon is anticipated with a certain sense of misgiving as one of the novel's couples, Gwen and Malcolm Cellan-Davies, discuss Alun in the context of Brydan and Welsh authenticity, without whom and which, they argue, Alun, whose poems are "sub-Brydan", might be nothing:

After lighting a cigarette Gwen went on in the same quirky style as before, 'I don't remember you as great believer in the integrity of Alun Weaver as an embodiment of the Welsh consciousness?'

'Well, I suppose in some ways, all the television and so on, he is a bit of a charlatan, yes, maybe.' 
'Maybe! Christ Almighty. Of course he's a charlatan and good luck to him. Who cares? He's good fun and he's unstuffy. We could do with a dozen like him in these parts to strike the fear of God into them. We need a few fakes to put a dent into all that bloody authenticity.'

'Not everybody's going to be glad to have him around,' said Malcolm, giving another section of toast the standard treatment. (12)

In The Old Devils Amis aligns the old with the desirable and authentic, and the new with the inauthentic and transitory in contemporary life, and funnels these concerns, as Dale Salwak puts it "through the microcosm of deteriorating human relationships". ${ }^{4}$ The physical ill health of the ageing drinkers is paralleled, however, with the ill-health of their failing marriages. The ever-present veil of alcohol acts as camouflage for Amis's penetration of his characters' personal defences, revealing old scars and the frailty of social relations; he probes behind the veneer of social pretence that centres on the concept of Welshness. The Wales which Rhiannon remembers after years of living in England displays the quality which all Amis's characters seek: something elusive and ephemeral, ineffable, a regional sensibility as expressed in the poetry of Brydan but frustrated in the writings of Alun and Malcolm. Rhiannon's sensitivity plays counterpoint to Alun's crassness. In her passive resignation she is able to experience the quality of Wales that the others merely talk about, an Amisian vision of nostalgia for the past and decay in the present (a quality of Amis's anti-modern stance which shares something with Evelyn Waugh):

Anyway, it was Wales all right, as Rhiannon Weaver reckoned she could have told by the look of it through the carriage window. There was no obvious giveaway, like road-signs in two languages or closeddown factories, but something was there, an extra greenness in the grass, a softness in the light, something that was very like England and yet not England at all, more a matter of feeling than seeing but not 
just feeling, something run-down and sad but simpler and freer than England all the same. (60)

Rhiannon's reflection on the train journey home is contrasted with Alun's egotistical and fatuous T.V. rhetoric in an interview filmed at Cambridge Street station:

'Tell me, what does it feel like to return to live in Wales after all these years away?'

'Many things grave and gay and multi-coloured but one above all: I'm coming home. That short rich resounding word means one simple thing to a Welshman such as I, born and bred in this land of river and hill. And that thing, that miraculous thing is-Wales. Fifty years of exile couldn't fray that stout bond. Heart is where the home is, and the heart of a Welshman ... .' (64)

Rhiannon, however, observes no bright colours, and things to her seem more or less unchanged, the station seems "incredibly typical"-"South Wales at one go", and she remembers it without Alun's infectious but puerile bravado. Alun, however, even in "semi-retirement" is restless, his return is to be " . . [a] small private voyage of discovery". 'It's all too easy for an exile come home to stay where he lands up, to cultivate his garden and never look over the hedge, to become something of a vegetable himself. That won't do for me, I'm afraid. I'll be going out, out in search of Wales, looking at things, looking at people." (81)

Alun, as chief devil, is well versed in handling his own public relations, however, and ultimately his selfishness ensures that he cares little what his friends, or anyone else, think of his claim to genuine "Welshness". Inauthenticity is evoked in the adoption of Welsh names for places that were never so named originally, the forced reading of provincialism from the metropolis: 
'Who? Fuck who?'

'The London bastards who changed all the Welsh counties about. Even my kind of Welshman resents that. And then gave them all these crappy ancient names.'

'It was done in the interests of efficiency.' Malcolm was nothing if not fair minded.

'That's where you're wrong. It was done in the interests of my bum.' (130)

Alun's shallowness is pitted against the construction of a pseudo-Welshness by the authorities, the phoney ancient customs for which "research had failed to come up with a date earlier than 1920". Even Brydan, who wrote in English, could not "understand" Welsh, despite Alun's assertion that he could in the "passion and spirit" of a true Welshman. Charlie takes Alun to task over this claim from his interview, making the distinction between bullshit and nonsense: "' . . . Stick to bullshit and we're all in the clear.'" (134)

Within the concept of a post-imperial literature, a literature in the aftermath of empire, The Old Devils examines the pretentiousness and precariousness of national or regional identities based on either a misplaced nostalgia or metropolitan interpretations of parochial living. Within this framework it explores the ideas of cultural authenticity and the authenticity of relationships, and demonstrates the ultimate impossibility of a return to an original culture. The Old Devils also articulates a frustration with the shallowness of contemporary nostalgia in which cultural identity is revived through the pastiche of historical references which were never assembled in any previous meaning beyond that of stereotype. The Old Devils plays with the notion of authentic cultural depth and its more shallow commodification in the age of the international tourist.

In this respect the novel both participates in, and mocks, the concept of a Celtic revival that is examined in different ways in much of contemporary British fiction from Roddy Doyle's "Barrytown" trilogy, Paddy Clark $\mathrm{Ha} \mathrm{Ha} \mathrm{Ha,} \mathrm{James} \mathrm{Kelman's} \mathrm{Scottish} \mathrm{realism}$ 
of A Disaffection, and How Late It Was, How Late. This revival strikes a parallel with Hulme's preoccupation in the bone people with the Maori Renaissance within a New Zealand context. Myths of nation and tribe collectively enjoy a revival in a contemporary cultures after empire, with the focus on local knowedge and representation rather than the fierce and sometimes inarticulate nationalisms associated with New Literatures during the 1970s.

\section{Towards an Irish Literary Post-modernism: Roddy Doyle's Paddy Clarke Ha Ha Ha}

Roddy Doyle won the Booker Prize in 1993 for Paddy Clarke Ha Ha Ha, a novel very much in the light-hearted satirical vein of his Barrytown trilogy of The Commitments (1991), The Snapper (1990) and The Van (1991). Like these earlier comedies, Paddy Clarke is set in the fictitious working-class suburb of Barrytown, located in North Dublin, and the novel deals with growing up in the suburban jungle of the contemporary Ireland of the mid 1960s.

The novel is unusual as a Booker Prize winner not only for its Irishness but also for its overt humour and demotic realism. While ostensibly it would seem to occupy a place at the opposite end of a contemporary "English" literary spectrum from, for example, Byatt's high-brow and metafictional romance, Possession, the novel which won the Booker prize in 1990, nevertheless the two novels share a concern with a general sense of Celtic national revivalism. They are both novels which negotiate a place for Celtic identity within the proliferate nationalisms of an international literary "English". Paddy Clarke intimates a newly articulated Irish literary engagement with post-modernism which distances itself from the legacy of Irish post-colonialism and the concomitant concerns with national identity defined in terms of colonisation. The demotic realism of Doyle's "Barrytown" trilogy demonstrates a concern with suburban pop culture which, in so far as it recognises shifts in populist influence, reflects the entry of American culture into the 
living rooms and teenage and middle-aged consciousness of late-twentieth century Ireland.

To invoke an Irish literature, as the cliche has it, is to invoke the discursive traditions of a people steeped in storytelling, myth, and an intensely rich linguistic, cultural and artistic heritage. Within the last century, the writings of Irish revivalist Yeats, modernists Joyce and Beckett, contra-modernists Flann O'Brien and (in a different way) Behan, Celtic revisionist Seamus Heaney, and metropolitan Irishman Dermot Bolger, invoke a culture whose literary stature and traditions have evolved in a direct and inverse relation to problems arising out of a fragmented, oppressed, yet always intensely courted sense of national identity.

If Paddy Clarke is to be ostensibly affiliated with any other genre or generation of Irish writing it is with the contemporary cosmopolitan social realism of the early Dermott Bolger. Doyle, while not quite a realist and certainly more comic than Bolger, nevertheless imagines an Irish writing with the same kind of narratological freedom presumed by Bolger's newly articulated Irish cosmopolitanism in which Ireland and in particular Dublin is understood as a centre rather than a city on the margin.

Much of Doyle's work centres on young protagonists, be they the youths of his early play Brownbread (1993), those in his novel The Commitments, or those who are a part of the childhood world of Paddy Clarke himself. Doyle's fictitious community is frequently, but not exclusively, portrayed through the comic-realism of a child's imagination. However, The Van and The Snapper are as much about the parents' generation as they are about Barrytown youth. While Doyle inherits a lineage of Irish writing that spans the Irish revivalism of Yeats and the latterday Celtic revivalisms of Seamus Deane and the Field Day project, he nevertheless does so through the eyes of an Irish generation belonging more to the cosmopolitanism of Bolger. As Bolger himself has suggested:

Fewer recent Irish writers can have caused more controversy in Ireland than Roddy Doyle (b. 1958), who, with his at times inflated 
comic characters, has-together with the playwright Paul Merciercreated a new and vibrant genre in Irish literature. The primary aim of any writer of quality is to create his or her own fictional universe and in Barrytown (where his trilogy of novels is set) Doyle has created his own distinctive and original set of characters who have added vitality and humour to Irish fiction. 5

Doyle's Barrytown children want to grow up, however, and they do so within a society that is dissimilar to that of the preceding generation. Gone, for example, is the Dublin of Joyce, the shell of a classical era in which the troubles of the present were played out against modernist themes of exile and fragmentation. In its stead is a spiralling metropolis in which neon, crime, gambling and drug culture replace the etiolated candle-light of the Celtic haunt. While it makes no sense to call this generation that of the "Irish post-colonial", for the terms of its identity are not strictly played out against the opposition of a post-imperial response to British colonisation of Ireland, neither are they to be defined by a return to a romantic Celtic nationalism. Rather, the writings of the contemporary generation offer articulations of a newly emerging movement of Irish post-modernism that reflects a cosmopolitanism that is in the process of disentangling itself from the historical dialectic of post-colonialism. The Irish of Doyle and Bolger live within a changing post-modern society in which the familiar problems of identity are still being articulated and negotiated in faintly echoic terms of a colonial and post-colonial past but they take place within a cosmopolitan present in which the dissociation from this historical legacy is as much a matter of course as of contrivance. This process of cultural change occurs ineluctably as Ireland opens up to the multifarious cultural and economic influences of a laissez-faire post-modernity.

Dublin has now its own metropolitan identity amid an international post-modernism. Bolger's argument centres on the notion that such a literary image was constructed not ostensibly by the Irish themselves but by an "occidental" reading, similar to that deconstructed in Said's Orientalism (1978), in which the non-Irish sought to contain the 
Irish within a false and static image of national character. Instead of Bolger's panoramic realism, however, Doyle frequently writes from the anamorphic perspective of childhood. Large, often tumultuous events are perceived through the naive emotional acuity of a child. This is the world of Barrytown adulthood in microcosm, through which Doyle variously and subtly explores the themes of reality and wonderment, cruelty and compassion, humour and pathos from the child's point of view. Despite his pervasive and witty humour, however, Doyle is not overly sentimental or nostalgic. With Paddy Clarke, Doyle continues his humorous Barrytown comic genre, but the novel is underscored by a note of poignancy engendered by the rift that develops between Paddy's parents and between Paddy and his younger brother, Francis or "Sinbad". Paddy's Barrytown world is one which simultaneously juxtaposes violence and sensitivity with humour and pathos.

Paddy Clarke is a novel of style-switching with its mix of words from different language registers. It contains both Gaelic words with translated subtitles and references to the everyday demotic world of television culture within a text that is mostly composed of dialogue with the abruptness of the child's attention span. ${ }^{6}$ Doyle's engagement with style-switching sets up a parodic structure by means of which he juxtaposes the "dead" hieratic Gaelic language of the past with that of the newly invigorated demotic language of popular and mass culture introduced largely via the media and particularly through the television screen. Whereas, for example, the pop-cultural thematic is the "Dublin soul" of his earlier novel The Commitments, in Paddy Clarke it becomes one of television culture, with Paddy's lounge becoming a playground for the adventures of "Napoleon Solo" of The Man From Uncle fame. The juxtaposition of these dichotomous elements establishes an ironic tension that is played out at both linguistic and social levels in the novel. The familiar concerns with autonomy and identity are apparent in each, but in Paddy Clarke as with the earlier play Brownbread, they take place within the context of an American cultural influence which gradually subsumes the more familiar and entrenched post-colonial concerns. Childhood fantasies and a child's consciousness are played out against a world of suburban adult problems. The anniversary of the 1916 
Proclamation of Independence is announced on a tea-towel which a nationalistic teacher brings to school. The teacher orders the children in a Gaelic to which the "walls of the prefab wobbled."7 Thus, while the novel is definitively "Irish", it has a universality that is invoked through attention to the "surface" world of demotic media culture and through child consciousness, be this the pronunciation of "Adidas", or in a game of football:

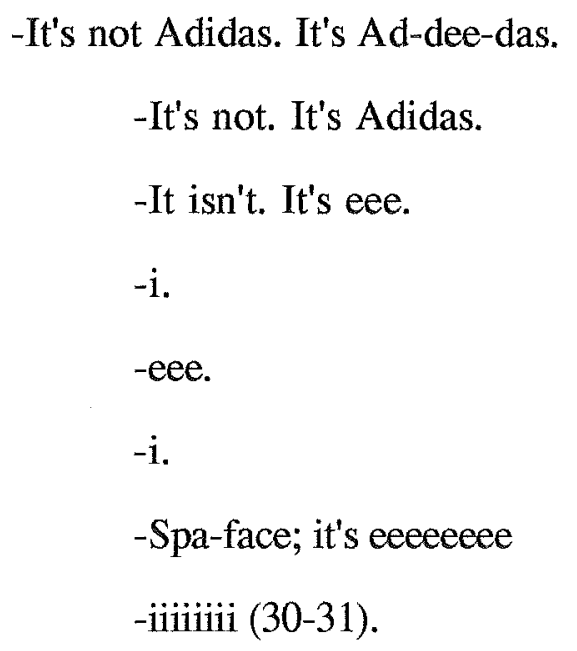

I shook hands with Kevin. We squeezed real hard. We were Northern Ireland. Kevin was Scotland. Bobby Charlton was playing for Northern Ireland because he was on his holidays there (168).

In Paddy Clarke the use of Gaelic words occurs in the context of Irish nationalism of the older generation, and amongst a faintly remembered nostalgia, but it is a sense of cultural memory that the children treat with equal irreverence. Paddy is brought before the class as a liar when he pretends his grandfather is Thomas Clarke, named on the teatowel of independence. In fact, Paddy's grandfather was not the executed freedomfighter of, amongst other things, domestic iconography, but alive and living in Clontarf. When Paddy recalls some old photographs that spilled from a side-table, he remembers his father's reaction to a request to visit grandma Clarke: "My da looked like he'd lost something, then found it, but it wasn't what he'd wanted." (23) 
Doyle demonstrates that humour is as effective as any other medium for the articulation of social concerns, and can go some way to circumvent the binary of social conflict expressed through Irish linguistic differences. In fact, while Paddy Clarke does go some way to preserve a language falling increasingly dormant in the contemporary present (admittedly the novel is set in 1966), the social topography of Doyle's Ireland is one in which, as Fintan O'Toole puts it in his introduction to Bolger's A Dublin Quartet: "New places have been born, places without history, without the accumulated resonances of centuries, places that prefigure the end of the fierce notion of Irishness that sustained the state for seventy years. Sex and drugs and rock ' $n$ ' roll are more important in the new places than the old Irish totems of Land, Nationality and Catholicism."8

As O'Toole points out, however, this loss of a sense of history offers a liberation from the past. The "new" urban and suburban Ireland is one in which history is fractured and buried beneath the synthetic jungle of the metropolis. For O'Toole the past should not be forgotten but neither should it be prioritised over the present; it should not be a burden to the forces at work in shaping a new literary Ireland. As he sees it, the product is one of a literary restlessness, not necessarily the modernist voyages of exile, but of fictions in which it is possible to step outside history, to rewrite history's familiar linear plot. Ironically, it is because Bolger and his contemporaries do not see themselves as constrained by an obvious tradition, either literary or Irish nationalistic, that they are able to do this. Gaelic language and Catholicism are two points of reference in a culture of international multiplicity. As O'Toole puts it:

The juggernauts whizzing by on the motorway carry not the burden of history but goods for export from the Most Profitable Location in Europe for American industry, as the ads in Time magazine call the new Ireland. The great tradition of Irish writing is silent on the subject of suburbs, so you can slip out from under its shadow. No one has ever mythologized this housing estate, this footbridge over the motorway, that video rental shop. It is for the writer, virgin territory. ${ }^{9}$ 
Thus, the colonial and post-colonial concern with nostalgia for Irish essentialism is supplanted by a sense of possibility in the contemporary post-modern cosmopolitan present. Doyle, through his fictitious suburban Barrytown community, has perhaps more than any other contemporary Irish writer combined a sense of the past with one of a liberated future. However, Doyle does not completely distance himself from the residual dialectic of post-colonialism-it is implicit in the minutiae of demotic details of his text from the teacher's tea-towel to Paddy's claims about his grandfather. In Doyle's work the past does not hang heavily over the hearts of Barrytown youth; theirs is not so much the Celtic revivalism of Yeats or neo-revivalism of Deane, but one in which spirit is retained in the demotic vigour of the present within a pervasive and acutely observed humour. But behind the adult generation is the grey wall of despair and this is rendered as a powerful absence in the novels. The Catholic and Protestant conflict and the dismal standard of living that have characterised Irish society for generations remain as counterpoints to the window of change and possibility reflected in Doyle's and Bolger's writing.

Participating in the genre of Doyle's familiar Barrytown comedies, Paddy Clarke isolates the humour of Doyle's previous novels underscored by a deeper social comment. His novel in many ways could be said to signify the birth of the generation of Irish literary post-modernism, and the young writers in Bolger's Picador anthology are also variously literary exemplars of this. A new generation of Irish writing-forged from a troubled past, aware not only of a history of Celtic richness but also of the familiar story of national fragmentation and dis-ease-nevertheless emerges forcefully in a cosmopolitan internationalist European era in which it is possible, and indeed presumed necessary, to step aside of history and negotiate new identities in the present. Once again it is as if Irish identity is conditioned by fragmentation and disruption, yet now is liberated by a sense of cosmopolitan post-modern multiplicity in the contemporary present. It is not too difficult to imagine Paddy as the image in Bolger's play One Last White Horse-a child drawing pictures in the steamed-up window of a bus in which his 
face is reflected. As O'Toole puts it: "The face is real; the setting is resolutely downbeat; but the image that is reflected has its own surreal logic, and the pictures that are drawn on it are the cyphers of the imagination." 10 For Doyle, this "imagination" takes shape in an all-pervasive sense of humour and pathos played out in the living rooms and suburbia of a newly post-modern Irish cultural climate.

\section{Grim and Demotic: James Kelman's How Late It Was, How Late}

Dark and sardonic humour forms the basis of James Kelman's 1994 Booker Prize winning novel of Glaswegian under-class adversity, How Late It Was, How Late. Blackly comic, Kelman's novel is written in a realist mode similar to that of Irishman Dermot Bolger. In this, his fourth novel, Kelman has honed and refined the Glaswegian demotic dialect that he has explored and developed in his earlier novels. The "story" takes the form of a week in Sammy's life, in which, after a bout of severe drinking, he wakes up to find his boots replaced by trainers, his memory impaired, and his identity in tatters as he stumbles through the early hours of a Glaswegian morning.

Conceptually, How Late It Was, How Late would seem, at first, distant from the novel of British "Victorian" post-modernism, A.S. Byatt's Possession. However, the two Booker Prize winning novels, four years apart, occupy opposite ends of the same contemporary British revivalist literary continuum. They demonstrate literary responses within the British Isles to the state of life and literature in a contemporary post-imperial setting. Where the one novel explores the world of literary-criticism in a metafictional detective fashion, the other fashions a grim realism, a demotic picture of life in a bleak and unremitting environment. Both novels are significant, albeit vastly different, points of revival for a sense of a contemporary literary Britain. Both explore the legacy of language for their particular class representations, both concern the untidy endings of empire, the sense of futility and restlessness that follows from the constant reassessment of the past. Sammy's world is immediate, and the time-frame of the novel occurs in his recent memory behind which is drawn a life of struggle and despair. With the freedom of 
the middle-classes, the world of Roland and Maud in Possession is played out with meaningfulness in the present derived from a sense of incompleteness in the past, a compulsion to finish a story begun a long time before. For both novels the past sits uneasily with the present, as if the sense of time is confused, the present providing too treacherous a standpoint from which to make regular and ordered sense of historical development.

Kelman's attempts to articulate a separate national identity are through class and language differences. Like Roddy Doyle's Ireland and Kingsley Amis's Wales, Kelman's Scotland remains a nation struggling to assert its identity independently from a country from which it is indistinguishable by colour. Furthermore, Scotland, like Ireland and Wales, is not an organic and unified culture. Throughout the body of his work since the 1960s, Kelman has been concerned with dialect, a Scottish patois and a workingclass realism. He has portrayed a disaffection for bureaucracy and what he sees as the giant and blundering stupidity of the "system". Over a ten-year period Kelman has consolidated his position among a generation of critically acclaimed Scots writers which include Agnes Owens, Alisdair Gray, and Jeff Torrington. While he has enjoyed critical success for his novels The Bus Conductor Hines (1984), A Chancer (1985) and A Disaffection (1989), which was a runner up for the Booker Prize, Kelman has also published a body of short stories, which also have received critical acclaim. Like his novels, the stories are often pithy, portraying acutely observed moments of human compromise, anxiety, or pathos within what are frequently working-class Glaswegian settings. Titles for his collections such as Not not while the giro, and other stories (1983), Greyhound for Breakfast (1987), and The Burn (1991) reflect the demotic and idiosyncratic sources of his stories.

Kelman's work is inflected with a black humour through which his protagonists grimly gaze against the world. It is this bitterness that ultimately defines both Kelman's Glasgow and the emotional register of his realism. A Scottish black humour coupled with a demotic regional, parochial dialectic provides the idiosyncratic tone and form of Kelman's writing. Kelman participates in a process which both Roddy Doyle and to 
some extent Dermot Bolger explore: the representation of a spoken tongue, an oral language in written form. Such prose has become increasingly characteristic of an attention to regional styles and codes within a rapidly expanding international sense of "English". It locates the narratives of a post-modern parochial present within a sense of a Celtic literary revival. As Edwin Morgan says of the work of Kelman and Alex Hamilton: "Without drawing extravagant conclusions, one can perhaps find from such examples how dialect prose fiction is edging its way into new territory, and at the same time is consolidating its won ground by giving - what had never been given before-a truthful account of the spoken tongue. In this it stands halfway between drama and poetry."11

How Late It Was, How Late is aptly described as being half-way between drama and poetry. However, it is the poetry of the demotic, a lyrical guttural prose style in which ellipsis and onomatopoeia provide linkages between the written form and spoken dialect. It is also a novel of the immediate: Sammy's "speech" and inner second person plural voice represents his conscious thoughts about life and provide the narrative threads of the novel.

Unlike the Gaelic in Paddy Clarke or the "Irish words" of Dermot Bolger's Night Shift, How Late It Was, How Late is written entirely in Glaswegian dialect. This becomes a thematic thrust of the novel: demotic speech is no longer counterpoint to a hieratic literary form, nor is it a celebratory form of patronage but rather the language of reality - a used tongue, which is not to say popular or popularist. Kelman achieves what few if any other Scottish authors have done in avoiding what Edwin Morgan calls a "disjunction" between realistic Glaswegian dialogue and heavy authorial English in the narrative. Contrapuntally, the reader is aware of an England not dissimilar to Sammy's world of frustration and squalor. As Adam Mars-Jones puts it: "Kelman's aim as a writer-which might be imagined expressed as no authority but in authenticity-leads him into producing something curiously unaffecting, a piling up of inarticulations." 12

How Late It Was, How Late is a novel of post-imperialism. Sammy is an indomitable but heavily oppressed character in an entropic Britain in the throws of post- 
industrial change. While Sammy is symptomatic of life as a middle-aged Glaswegian beneficiary, he is not portrayed against a backdrop other than the social forces which helped shape him and against which he constantly rebels. His context never changes. Again as Mars-Jones puts it: "Kelman's fiction . . . has a political agenda superimposed on it, which seems compatible but actually clashes: that of giving a voice to the voiceless, those whom society and literature ignore." 13

In How Late It Was, How Late Kelman articulates a language which redresses the balance between the hieratic notion of "English literature" and the demotic realism of language at source. At the same time Kelman articulates a newly acquired sense of Scottish identity within British culture. As Michael Keating puts it:

There is not a single homogeneous Scottish national culture; such would be the mark of ethnic exclusiveness rather than national maturity. There is, however, a cultural dimension to national life and a national dimension to cultural issues which was absent in the past. There is more self-confidence, less tendency to dismiss Scottish culture as second rate and a greater willingness to see it as part of the broader European scene. Culture is no longer a retreat from social and political reality but a way of viewing it and discussing it. This reality is of a pluralistic and modern society whose place within the United Kingdom and Europe is problematic and which contains within itself acute social and economic problems. This provides an important underpinning for national identity and, indirectly, since most culture is not explicitly political, for nationalist politics. Scotland, in this respect, has become a nation like others. ${ }^{14}$

Kelman's Great Britain is thus one of class structure, suppression of the poor, corruption, monopoly, internal rift and hypocrisy. However, it is also one of resistance and the possibility of redemption through honesty and dignity in the face of adversity. In 
his dedication Kelman acknowledges a camaraderie with a handful of contemporary Scottish writers who articulate a particularly angry and even counter-discursive response to the condition of a post-imperial Scotland: Alistair Gray, Tom Leonard, Agnes Owens, and Jeff Torrington. Each of these writers is concerned with various forms of contemporary post-imperial Scottish literature, poetry or criticism, each articulates a literary form which demonstrates a disaffection the canon of a hieratic modernist English literature, while establishing a particular and peculiar Scottish resonance. However, Kelman's grim and demotic realism is belied by the novel's complex and sophisticated punctuation. As Mars-Jones puts it:

For Kelman, authorial distance seems to be a form of literary imperialism. It is certainly an illusion, but so to be sure is the supersedure of the author by his creature. In the first sentence of How Late It Was, How Late for instance, Kelman uses six semi-colons and a single colon, a near exquisite piece of stopping that belongs to a different world from Sammy's. This other world is one which, among other things, would make political analysis possible. All Sammy can do is exemplify the sufferings of his region, his history and his class. The fact that this stoicism, a virtue on the personal level, is from a different point of view a guarantee that he will remain in his place, is an irony the book refuses to house. 15

How Late It Was, How Late, while unconventional and a sparsely "plotted" slice of life in demotic Glaswegian dialect of the bedraggled Sammy, is written in almost archetypal realist vein. Whereas in Roddy Doyle's Paddy Clark Ha Ha Ha there is eventual disintegration of the Barrytown family, in How Late It Was, How Late there is a kind of reconciliation (and a scene of pathos) between Sammy and his now matured but estranged son. A subtext in both regionalist novels, family disintegration aside, is a search for a father figure, for a sense of authority that is not the authority of the state, but 
one of local meaning and personal relevance. Both Doyle's and Kelman's work is concerned with the rifts between people, the problems with relationships, the search for a just and humane sense of authority and the rejection of and resistance to the established authoritarianism of government or the state. Kelman's Sammy is an incorrigible figure who has spent a life in and out of trouble with the law; while he is no angel he at least admits his numerous faults and negotiates a life of some kind of dignified resistance to the social forces which have shaped his general predicament and precipitated the drunken bender from which he has just awoken, only to find himself blind. Perhaps, again like Lowry's drunken consul in Under The Volcano, the novel articulates a dark pun on the condition of national blind-drunkenness:

And time went on. And he was sitting there in his blank sort of void, the mind going in different directions. No all nice either, no by any manner of means, cause he hadnay led the best of lives. No the worst but no the best. He had aye been a bit stupit. And there's nay cunt to blame for that except yerself. Ye aye come back to the same thing. Nay point blaming the sodjers if you've ladled into them in the first place; fuck sake man ye cannay blame them for giving ye a doing. ${ }^{16}$

Kelman's point is that the context of Sammy's life conditions both who he is and what he thinks. Sammy sums up the story in his own words: "Folk take a battering but, they do; they get born and they get brought up and they get fuckt. That's the story; the cot to the fucking funeral pyre." (16)

In How Late It Was, How Late Kelman is concerned with writing through the stereotypes endorsed by what he perceives as a hieratic "English" literature. In portraying Sammy through Sammy's own eyes, in constraining the novel to the interior monologue of a single blinded character, Kelman both reifies and subverts through realism the stereotype of the drunk Glaswegian. He portrays Sammy as a belligerent victim of an oppressive society in which the few trample on the heads of the many. 
These few, the ruling elite, are usually those who have created themselves in the image of the English elite, and who help foster and maintain the stereotypes which, whether true or false, confine the working-class Glaswegian character and provide a discursive means of control or a language of exclusivity. However, the recipient of the Booker Prize for How Late It Was, How Late, Kelman gains recognition for locating a sense of the regional, the demotic, the parochial, firmly within the canon of "English" literature; a tension between the visceral prose and an intricate and sophisticated punctuation and syntax permeates the novel. While How Late It Was, How Late is entertaining, aesthetically interesting, well written, and even lyrical in its own right; the awarding of the Booker Prize to it is significant in that it foregrounds a demotic parochial Glaswegian within a canon of predominantly British literature.

Kelman has been singled out among contemporary Scottish authors as symptomatic of a new Scottish literary revival, one that looks less in nostalgia to a romantic past, but either assembles in pastiche an imperial history in the post-imperial present (as with Gray's Poor Things (1985) and some of the poetry of Edwin Morgan), or is concerned with realism and attention to language and character at source (as, for example, with Kelman, Agnes Owens, or in the Irish context, Dermot Bolger). Running through both of these strands is the common theme of a concern with the demotic. It is as if a Scottish nationalism is negotiated between the poles of a demotic regionalism and an AngloWestern internationalism. As Kelman again says of the Glaswegian dialect and regionalism:

There is nothing about the language as used by the folk in and around Glasgow or London or Ramsgate or Liverpool or Belfast or Swansea that makes it generally distinct from any other city in the sense that it is a language composed of all sorts of particular influences, the usual industrial or post industrial situation where different cultures have intermingled for a great number of years ... All of these are at play in my work, as filtered through my own 
perspective, a perspective that, okay, is Glaswegian, but in these terms

'Glaswegian' is a late 20 th century construct. ${ }^{17}$

Kelman is thus a politically engaged author. How Late It Was, How Late demonstrates a form of counter-discourse as well as a participation in a wider movement of Anglo-Saxon and Celtic revivalism. For Kelman, society is at least as oppressive of the working class, in respect of cultural and artistic autonomy, as, for example, it is for Nadine Gordimer or J.M. Coetzee.

Kelman's novel relocates a sense of the regional and the demotic at the heart of an "English" literary canon. In so doing it subverts and undermines the notion of an exclusive hieratic "English" voice of the elite, while at the same time establishing firmly that post-imperial Britain has its own internal problems and crises of identity, as pervasive as those of the nation-states of the former Commonwealth. If the Booker Prize can be said to confer canonical status on a novel, then How Late It Was, How Late could be said to resist the totalising influence of the Prize, a resistance fundamentally to the dialectic relationship between inclusion and exclusion or the language of accommodation and hegemony that the award of such a Prize entails. The realism and regionalism of Kelman foregrounds the notion of a national identity to be negotiated between a local and parochial response on the one hand and global internationalism on the other. A national Scottish identity in the contemporary post-imperial era, like that of the Irish, is likely to be articulated by local parochial literatures distilled through the international gaze. As Michael Keating points out: "Loss of empire has eliminated one item in shared identity and exposed the weakness of British national identity." 18

\section{Conclusion: "Post-Imperials": The British Post-colonials.}

The Old Devils, Paddy Clarke Ha Ha Ha, and How Late It Was, How Late are marked among the Booker Prize winners by their articulations of specific illustrations of generalised Celtic nationalist-historical cultural types and values. The narratives of these novels engage with the problems of authenticity, ethnicity and originality, with the often 
contested idea of a re-discovery of pure or culturally authentic origins that re-emerge from within the amalgamation of identities that comprise the cosmopolitanism of contemporary Britain. Revivalisms are illustrated in the laying of claims to cultural identities eclipsed by the process of colonisation or a reverse colonialism in empire's wake.

One of the central issues that is explored in these novels is the confusion between an understanding of society as having an origin and the notion that some elusive quality is "natural" to society. A similar division occurs among the theoreticians of postcoloniality; there are those who subscribe to ethnic essentialisms and cultural nationalisms and those who adhere to the model of fluidity, hybridity and flux of globalisation. The contemporary cultural climate is evenly divided between essentialists who believe that culture is reducible to a central essence and their counterparts, like the Indian writer and intellectual Salman Rushdie and Sri Lankan Michael Ondaatje, who argue that underpinning their sense of identity is the idea that culture is multiple, indeterminate and ever-changing. However, this division is not absolute or binary because neither group is necessarily mutually exclusive. Hulme and Kelman are essentialists believing that culture has an underlying core while Doyle and Amis are non-essentialists, slyly undermining the idea of a mythical source for communal identity.

In the introduction to Nationalism, Colonialism, and Literature in the context of the Irish Field Day enterprise, Seamus Deane points out:

A society needs a system of legitimation and, in seeking for it, always looks to a point of origin from which it can derive itself and its practices. ... But the search for origin, like that for identity, is self-contradictory. Once the origin is understood to be an invention, however necessary, it can never again be thought of as something 'natural.' A culture brings itself into being by an act of cultural invention that itself depends on an anterior legitimating nature. This is not merely a paradoxical game whereby the answer to 'what came first?' is uselessly answered by 'whatever came second.'19 
It is with sense of "natural" national origin or identity that the Celtic revivalisms of Amis, Byatt, Doyle, and Kelman engage. All are haunted by pasts from which they cannot escape, and all look forward to futures always to be played out in terms of their pasts. Inherent in their localised national adumbrations is a deployment of the method but a rejection of the totalising form of post-modernism. The writers discussed here engage with the demotic, the local, the idiosyncratic. They participate in but contest the pluralism of post-modern cosmopolitanism. As Deane puts it in the context of Irish colonial history:

To remove ourselves from that condition into one in which all these lesions and occlusions are forgotton, in which the postmodernist simulacrum of pluralism supplants the search for a legitimating mode of nomination and origin, is surely to pass from one kind of colonizing experience into another. For such pluralism refuses the idea of naming; it plays with diversity and makes a mystique of it; it is the concealed imperialism of the multinational, the infinite compatibility of all cultures with one another envisaged in terms of the ultimate capacity of all computers to read one another. 20

Not only is the language frequently demotic but the focus is also on the ordinary and downbeat. While sometimes realist in mode, the product is a kind of characteristic pastiche of realism, neither distillation nor dilution, but a persistent conscious writing down, a shift in focus from the middle or high brow to the demotic, a shift of register that persistently acknowledges the spectrum of the class structure of British society after empire. The subjects of these novels have frequently been treated less well in the newly emergent cosmopolitanism after empire; they are either jaded by it (as in Amis's and A. S. Byatt's satires on academia) or they are everyday working-class people battling and attempting to beat everyday odds. These are all versions of a kind of nationalism 
engaged in the effort of questioning the idea of a national character and destiny. As David Miller suggests in On Nationality in the context of the decline of empire:

The ending of empire - not so much the formal hand-over of power as what happened thereafter-called into question a very long-standing set of beliefs about Britain's role in the world, and indeed about the intrinsic value of British institutions themselves . . . [T] he post-war experience of people in Britain has directly undermined the main elements out of which British identity was originally constructed. This accounts for the confused feelings that many experience when asked what it means to them to be British. On the one hand, there is a strong sense that the British do have a separate identity, and that this matters a good deal; on the other hand, it is far from clear what this separate identity is supposed to consist in. 21

Miller distinguishes between "cultural Englishness"-typically "English" ways of doing things - and British national identity which is more likely to contain the threads of many disparate nationalisms. Furthermore, the term "British" harbours an elision of English with "Other" in the attempt to mask English dominance over the territories with which England has enjoined in acts of colonial union. As Robert Young points out, "'British' is the name imposed by the English on the non-English."22 However, in contemporary times these "Kingdoms" are articulating something of a revival along the lines of nationalist independence. The newly articulated "nationalisms" are in part anticipated in those Booker Prize winners reflective of Celtic revivals, from Amis's comic-realist novel of Welsh ingenuousness to Kelman's novel of demotic Glaswegian adversity. These revivals emerge at the same time as the notion of English identity is changing. Geoffrey Elton has argued that historically the English experienced their largest and most traumatic change when they turned into the British. As Young again points out, "[being English] has never been successfully characterized by an essential, 
core identity from which the other is excluded." 23 Hence the inherent doubling at the centre of empire and the realisation that being British involves the elision of English with any number of its colonial affiliations. The recognition of this liminal status as "English" has empowered decolonising energies and encouraged the resistance by formerly colonised people to existing constructions of British identity. It is this ambivalence of identity that is signalled by the enigmatic Englishman of The English Patient, and sees Ondaatje's character as a metonym for a post-imperial paradigm of loss, and change. It is in defining this paradigm that the new Anglo-Celtic energies are articulated, fuelled from the deconstruction of previous myths of empire and British identity.

\section{Notes}

${ }^{1}$ Kingsley Amis, The Old Devils (London: Penguin, 1986), p. 12. All further quotations from this work are taken from this edition and are followed by the relevant page number in parenthesis.

${ }^{2}$ Barbara Everett, "Kingsley Amis: Devils and Others", inKingsley Amis in Life and Letters, ed., Dale Salwark (New York: St. Martin's Press, 1991), p. 89.

${ }^{3}$ Blake Morrison, "Not Untrue and Not Unkind", The Times Literary Supplement, Sept. 12, 1986, p. 994.

4Dale Salwak, Kingsley Amis: Modern Novelist (Maryland: Barnes \& Noble, 1992), p. 244.

5Dermot Bolger, ed., The Picador Book Of Contemporary Irish Fiction (London: Picador, 1994), p. xxiii.

${ }^{6}$ Mark Williams and Elizabeth Gordon, "Raids on the Artculate: Code-switching, Styleshifting and Post-Colonial Writing", The Journal of Commonwealth Literature. 33:2 (1998), pp. 75-96.

${ }^{7}$ Roddy Doyle, Paddy Clarke Ha Ha Ha (London: Secker \& Warburg, 1993), p. 21. All further quotations from this work are taken from this edition and are followed by the relevant page number in parenthesis. 
${ }^{8}$ Fintan O'Toole, intro., A Dublin Quartet by Dermot Bolger (London: Penguin, 1992), p. 1 .

${ }^{9}$ O'Toole, A Dublin Quartet by Dermot Bolger, pp. 1-2.

${ }^{10}$ O'Toole, A Dublin Quartet by Dermot Bolger, p. 5.

${ }^{11}$ Edwin Morgan, Crossing The Border (Manchester: Carcanet, 1990), p. 321.

${ }^{12}$ Adam Mars-Jones, "How Late It Was, How Late", The Times Literary Supplement April 1, 4748, 1994, p. 20.

${ }^{13}$ Mars-Jones, "How Late It Was, How Late", p. 20.

${ }^{14}$ Michael Keating, Nations Against the State: The New Politics of Nationalism in Quebec, Catalonia and Scotland (London: Macmillan, 1996), p. 171.

${ }^{15}$ Mars-Jones, p. 20.

16James Kelman, How Late It Was, How Late (London: Secker and Warburg, 1994), p. 16. All further quotations from this work are taken from this edition and are followed by the relevant page number in parenthesis.

${ }^{17}$ Kelman, Some Recent Attacks, p. 84.

${ }^{18}$ Keating, Nations Against the State, p. 172.

${ }^{19}$ Seamus Deane, Nationalism, Colonialism, and Literature (Minneapolis: University of Minnesota Press, 1990), p. 17.

${ }^{20}$ Seamus Deane, Nationalism, Colonialism, and Literature, pp. 18-19.

${ }^{21}$ David Miller, On Nationality (Oxford: Clarendon Press, 1995), p. 15.

${ }^{22}$ Robert J.C. Young, Colonial Desire: Hybridity in Theory, Culture and Race (London; New York: Routledge, 1995), p.3.

${ }^{23}$ Robert Young, Colonial Desire, p.3. 


\section{Conclusion}

\section{The Booker Prize and the Culture of Post-imperialism}

Edward Said's observation in Culture and Imperialism that literary history and empire are intractably entwined is the idea upon which the argument of this thesis is based, although my concern with the Booker Prize limits my analysis to the period after extensive decolonisation. Most of the major acts of decolonisation had been accomplished by the mid 1950s. By 1969, when the Booker Prize was established, Britain had ceased to be an actively imperial nation. The period covered in this study of the Booker Prize (from 1969 to 1995) encompasses nostalgia for empire in its expansive phase and anticipates the federalism of the new Britain of the late 1990s. It encompasses the compromising of British imperialism by Britain's entry into the European Community. This is the period in which the culture of post-empire takes shape, a culture reflected and influenced by the Prize.

Because all the Booker Prize winning novels, either from post-imperial or postcolonial perspectives, share in that culture of adjustment-all either directly or implicitly invoke empire or its aftermath-there is a sense in which this study participates in the discourse of post-colonialism. However, the term is not wholly apposite because, while post-colonialism claims to deal frontally with the culture of the colonised, it frequently invokes a binary retrenchment in which the past is represented in overly simplistic terms and the accommodations of post-empire and its multiple identities and subjectivities are rendered invisible. In place of post-coloniality, or conjointly with it, a culture of postimperialism arises: an expression of the culture after empire from the predominant perception of an English and more widely a "British" point of view. ${ }^{1}$ Analysis of the novels which have won the Booker Prize over this period demonstrates something of the complexity of identities in the contemporary post-colonial context. The novels collectively signal a conception of the post-colonial that resists the polarity of "for" and "against"; or one that recognises, for example, that a sense of "Britishness" may encompass any of the colonies with which empire had concerns. The post-colonial 
condition is a global development which articulates a collective re-imagination of identity among the peoples and nations of empire's wake. However, this perspective of a diffuse Britishness takes place in a world in which the local and global replace the national and the international. In terms of the increasingly complex interrelations among First, Second, and Third Worlds, being "international" now involves an anamorphism of scale, the ability to assert a local identity within a global context-the microcosmic worlds of James Kelman's Glasgow and Roddy Doyle's Barrytown Ireland, for example. In this respect Said's Culture and Imperialism isolates an area in a much more fluid context of global relations than even he imagines. What Said teaches us to "include" after a culture and history of exclusion by empire must take its place within a global context in which the boundaries of nation-states no longer securely define national differences. As Robert Wilson and Wimal Dissanaynke put it: "It is no longer adequate to map the globe into binary zones of center and periphery as an eternally Manichean space of colonial victimization nor even as Edward Said's rich culturescape of 'contrapuntal' imperialism." 2

However, it is also in this context of flexible late capitalism that the term "post-colonial studies" is becoming less meaningful in a similar fashion to the terms "Commonwealth Literature" and "New Literatures" of the 1970s and 1980s. If all nations which at some point have come under the sway of British imperialism are seen as post-colonial, then this term begins to lose its meaning; such cultures are more likely to be understood in terms of a combination of post-colonialism, post-imperialism and post-modernity, although what distinguishes these terms, apart from a concern with empire in the former two, is complex. The terms are not without a degree of self-reflexivity-it is not fully possible to step outside of them to gain an absolutely fixed picture of their meaning. As Mark Williams has written of Commonwealth studies:

From its inception, Commonwealth literature, like the Commonwealth itself, was a doomed attempt to discover links among a chaos of new 'nations', themselves the hangover of imperialism. As a means of 
making connections among the leavings of empire the new discipline raised more problems about culture, race, belonging, language and identity than it solved. The chief problem was that the concept of Commonwealth literature was fatally tied to the notion of an authoritative common tradition that was bound to conflict with the nationalist interests of the countries it sought to hold together. ${ }^{3}$

A novel which sets itself in opposition to the imperial process and which articulates a counter-discursive stance to the presence of the settler-invader would, being anti-colonial, seem to be accurately encompassed by the term "post-colonial". An example of such writing among the Booker Prize winners is Okri's The Famished Road, which narrates a lyrical and mythological response to the gradual Westernisation of a remote African village, ostensibly from the perspective of the pre-modern colonised. However, written in the language of the coloniser by an author living in contemporary cosmopolitan London and dealing with the interaction of cultures, pre-modern and modern, there is a tangible link in the conception and writing of the novel with British culture after empire. This takes the form of a tension invoked in the novel between the spectre of colonisation and the ghettoisation of the novel's indigenous peoples playing counter-part to the author's relationship with contemporary multicultural patterns of dispersion.

Timothy Brennan in Salman Rushdie and the Third World: Myths of Nation (1989), reflects on the demise of Britain as the controlling centre of the Commonwealth, and the disassembly and reformation of the Commonwealth nations into the cosmopolitanism of the contemporary world order. Brennan regards the writing of Salman Rushdie, who won the Booker Prize in 1981 for Midnight's Children, and the "Booker of Bookers" in 1994, celebrating the best of the Booker winners in its first twenty-five years, as paradigmatic of the contemporary literary internationalism that bridges the Third and First World Nations.

Brennan emphasises the pervasive nature of imperialism and its continued influence in shaping societies after empire. In doing so he recognises that this is no longer articulated 
from the perspective of a British literary tradition but from one in which Britain is seen as an "absent centre", as a nation with a lack of cohesive identity that is now defined more by writers writing about its disparate elements than by the binding notion of empire itself, which has been, as he puts it: "England's central reality for the last century and a half". As Brennan states:

Empire, after all, is not something done to others: it is a relationship, and it is in Rushdie's Britain that the effects of the relationship on the First World are most striking. The imperial leaders of the West for over two centuries have been English-speaking countries whose sense of literary tradition has avoided the global realities Rushdie forces into view. About twenty years ago, in a very widely read essay, Perry Anderson wrote of England's nullity of native intellectual traditions, its secular, insular stultification, the 'absent centre' of English intellectual life. ${ }^{4}$

The fact that Brennan is able to call the contemporary Anglo-literary climate "Rushdie's Britain" is a telling one for the perception that British literary culture is an "absent centre" both from which and against which contemporary "post-colonial" writers are writing. In essence, Rushdie's argument about centre and margin concerns "movement", translation, and hybridity — what can crudely be perceived as a writing back to the centre in London from the erstwhile colonies. However, Booker Prize winners such as Okri, Naipaul, and Rushdie are engaged in writing a form of decolonisation, by describing, among other things, the experiences of Third World immigrants to Britain, and at the same time the dissolution of the imperial presence in their native "homelands" which is often coincidental with the rise of national independencies. Such writings are not merely neat reversals of the colonial imperial process. Rather, as Australian poet Les Murray has put it: "the centre is everywhere." Empire has dispersed and scattered in its wake are new identities, nations, tribes, and selves that no longer necessarily battle from 
under the mantle of an overriding imperialism (although some may be subject to a neocolonialism). ${ }^{5}$ Neither is Brennan strictly accurate in his assertion that the literature of the imperial leaders "has avoided the global realities that Rushdie forces into view". For example, while the Booker Prize is predominantly British it has not always gone to British novelists. In fact even if Rushdie, Nigerian writer Okri, Japanese-born Ishiguro, and V.S. Naipaul are considered British, twenty "British" novelists have won the Prize over a twenty-six-year period, with the balance being made up of authors from the Commonwealth and Ireland. Thus the Prize reflects the awareness of an evolving literature from "centres" other than London. Brennan continues:

However, the spirit of Anderson's critique of 'absent centre' can be applied to the postwar British novel as a whole. Despite the brilliant work of William Golding, John Berger, Pat Barker, Alan Sillitoe, Doris Lessing and others, English novelists have managed to ignore what is really the essence of England right now-its being a colonising spirit with little to colonise but itself, an industrial nation assuming the colours of its underdeveloped former dominions, a racial and ethnic cross-section of the former Empire that is officially white-like Orwell's 'English people'. If the old-school view has been attacked by the revisionist critics, who popularised the contributions of the working classes to a common British identity ... none of them saw their way to challenging the mental (and, of course, actual) exclusion of the black communities. In fact they have had very little to say about Empire at all $\ldots 6$

In this, however, Brennan is incorrect. He cites two (English) Booker Prize winners, William Golding and John Berger, but leaves out such writers as Angela Carter, Peter Ackroyd, Martin Amis (also perhaps deserving winners), Penelope Lively, Penelope Fitzgerald, Anita Brookner, A.S. Byatt, Iris Murdoch, P. H. Newby, David Storey, and 
Barry Unsworth, all of whom articulate in their writing a particularly English response to aspects of British culture and society, empire and post-imperialism. Each of these writers is concerned with the vacuum left by imperial expansion, with the intimations of domestic change and unrest. It is not the spirit of the British novel but the subject-material of the novels themselves that reflects an "absent centre". Such writers demonstrate a tendency to look to the past, to a complex and rich British history, in order to articulate the possibility for British revivalism in the present. Brennan is mistaken when he claims that: "[t]he postwar English novel has produced almost nothing to suggest the seething energies of a specifically 'post-imperial' England, much less the 'other regions' with the hybrid characters, flooding in and out of contact with the centre." 7

The body of the Booker Prize winning novels are testament to the incompleteness of Brennan's reading. Excluding for a moment those with British citizenship, among its prize-winning authors Graham Swift, Roddy Doyle, James Kelman and Kingsley Amis could be said to have written about a specifically post-imperial England of English and Celtic "revivals", whereas there is another category of British novelists who in varying ways articulate the theme of entropy of empire and amongst whom could be counted Iris Murdoch, William Golding, P.H. Newby and Pat Barker. It is not that the British novel lacks post-imperial energies; rather, the focus is on what Brennan diagnoses as the eclipse of British literature in the light of literatures in Englishes from the post-colonial nations of the former Commonwealth. Rather than see these writing forces as independent of each other and mutually exclusive, it makes more sense to see them as operating in parallel as both are impelled by the logic of empire's demise:

... in the period following the Second World War, English society was transformed by its earlier imperial encounters. The wave of postwar immigration to imperial 'centres'-including in England the influx of large numbers of non-white peoples from Africa, South Asia and the Caribbean, and in North America from Asia and Latin America-amounted to what Gordon Lewis ironically calls a 
'colonialism in reverse': a process that has led unavoidably to a new national culture-a new sense of what it means to be 'English'. ${ }^{8}$

As Brennan persuasively argues in the context of Rushdie's fiction, English language and English literature is widely spread. We can no longer speak of an "English literature" but of "Englishes" and "English literatures". As Rushdie himself puts it, English "no longer an English language, now grows from many roots; and those whom it once colonised are carving out large territories within the language for themselves." 9

The tendencies and movements that Brennan observes as symptomatic of the shift between an Anglo-centric English literature and "World Literatures in English" are coeval with the development of the new nationalisms in the former settler-invader colonies. However, the same process is not, as Brennan observes, as readily apparent in Britain itself. The dissolution of empire coincided with the lack of self-confidence in British nationalism and even of the separate and separatist European nationalisms following the Second World War.

While the "cosmopolitan embrace" has encouraged the levelling of the hieratic canon of an "English literature" centred in Britain itself, it has simultaneously advanced the notion of a "world literature" in which the form of cultures after empire are constituted as a discipline in their own right. This discipline either takes the form of a "post-colonial" literature and the counter-discursive, decolonising literatures with which it is usually associated, or of those post-imperial literatures from within Britain itself.

Specifically English literary culture suffered something of an anxiety of confidence in the first few decades after the Second World War. The perception of Great Britain was of a nation reduced by the process of dismantling its empire. In the English novels of the post-war period, this process of entropy was marked internally even as the same process took place more visibly from without. As David Sanders puts it: "The story of the Empire "circle" after 1956 was fundamentally one of withdrawal. As the Empire became less manageable and less crucial to the preservation of Britain's vital interests, so London 
relaxed its imperial grip and progressively abandoned the 'world role' which Britain had played for almost two centuries." 10

At the same time responses from so-called "Third-World" writers from within Britain itself wrote of migrant experiences and the culture of ethnic displacement and realignment in an era of decolonisation and the diaspora of a "global" and shifting English. Resident British-Naipaul, Rushdie, Kazuo Ishiguro, and Okri-can be included among this group. As Catherine Hall observed in 1996:

The legacy of the British Empire is immediately visible in contemporary Britain, where $6.3 \%$ of the population are now classified as ethnic minorities. In urban areas such as London and Birmingham, where ethnic minorities make up over 20 per cent of the population, African-Caribbean and South-Asian people constitute the majority groupings. The decolonised peoples of Jamaica, Trinidad, Barbados, Guyana, India, Pakistan, Bangladesh and other once colonies of the Empire who have made their home in Britain, together with their children and their children's children, act as a perpetual reminder of the ways in which the once metropolis is intimately connected to its 'peripheries'. Both colonisers and colonised are linked through their histories, histories which are forgotten in the desire to throw off the embarrassing reminders of Empire, to focus instead on European future. ${ }^{11}$

Three processes affecting the novel in English took place simultaneously in the decades from the 1950s following from the collapse of empire. Many peoples from the former colonies emigrated to Britain and began to infuse British culture with that of other societies, hence the Jewish London of Rubens, and the Caribbean London of V.S. Naipaul, Wilson Harris, and George Lamming, for example. These groups were joined in the 1970s by those resident but not born in England who articulated a sense of double- 
culture, of belonging to two worlds-the so-called Third World Cosmopolitans. By the 1990s an established literary culture centred on domestic drama and the novel of morality was merely one trend among many ranging from the new novelists of Scotland and Ireland, to those trends such as magical realism and 'mimicry' among Caribbean, African, Asian, and Indian immigrants.

While an increasing number of these novels fall under the rubric of post-colonial studies they do not all express the anti-colonialism that is usually associated with that term although they all could be said to participate in a First World "Zeitgeist" that is, at least "officially", anti-colonial in its leanings. The battle for cultural dominance characterised by the imperial impulse continues to be played out within such discourse, albeit in changed form and in disparate ways. The introspection that gives rise to an awareness of the "Other" within has been transmuted into the theoretical and metaphysical complexities of the wider discourse of post-colonialism. If empire raised the awareness in pre-colonial societies of a global economy, it also raised within itself a consciousness of many and disparate identities that it sought to amalgamate. The process of empire established nationalities where none had existed before, even if these newly defined territories were characterised by their resistance to the dominant culture.

If the term "post-colonialism" is to continue to have purchase, it must signal more than the interaction of post-colonised and post-colonising cultures; it must also invoke a postmodern world in which the relations between patterns of human geography are increasingly fluid, shifting and complex. Furthermore, post-colonialism interacts with the climate of post-modernism in so far as it claims to resist its totalising narratives and binary configurations. As James Clifford's work on the "post"-cultural would suggest, the analysis of the Booker Prize winning novels takes place in, and reflects, a world in which the geography of empire is no longer meaningful in terms of a congregation of nation-states. The world is no longer divided among the nation states of the Cold War (or First and Third Worlds) era, but along the different lines of the local within the global economy where business and capital flows increasingly dissolve national sovereignty and where tourism and migration-all the strains of multiculturalism-mark increasingly 
hybrid or problematic identities. Decentred and multiple identities which span a number of cultures suggest that authenticity is relational and reconfigure a combinatory sense of selfhood within a global context. If what underpins the dispersion of peoples over geography is primarily economic in basis, then can post-colonialism be meaningfully expressive of contemporary cultural trends or does it act as cultural camouflage for its capital flows? Furthermore, as Dirlik puts it, "Now that postcoloniality has been released from the fixity of Third World location, the identity of the postcolonial is no longer structural but discursive."12 Postcolonialism may in fact label the cultural concerns of the intelligentsia of global capitalism, a group whose discourse bears only surficial relation to the movements of capital flow.

In The Predicament of Culture (1988) Clifford discusses the contemporary condition of societies in which it is increasingly difficult to attach identity, meaning, or "authenticity" to a coherent culture or language or to a discourse which seeks to do so. ${ }^{13}$ Clifford argues that the pattern of cross-cultural influences of today no longer involves the gradual absorption of non-modern cultures to modern; rather, the non-modern has an almost equally powerful effect on the modern. Clifford does not envisage the world as populated by endangered authenticities, but rather as a globalism that harbours improvisatory and combinational cultural responses in which the Third World plays itself against the First, and vice versa. If, as Clifford suggests, authenticity is relational, then identities can no longer be stable and "self-other" relationships are a matter of power, rhetoric, and discourse, rather than of cultural "essence". For Clifford, traditional cultures are without regret for their histories and are newly syncretised as part of an inevitable, ongoing, process. This process in turn highlights global interconnectedness in the legacy of imperialism. As he puts it in "The Global Issue: A Symposium":

... at least three processes are always going on. One is the disappearance of certain orders of difference. The second is a process of translating orders of difference. And the third is the creation of new orders of difference. This last, I would divide into two locally 
interconnected dimensions: first, imposed or neocolonial forms, stemming from an economic relationship to the state or the wider world system; and second, emergent orders which are invented out of historical debris, moulded from indigenous and foreign material. ${ }^{14}$

Clifford thus sees the "new global order" as challenging traditional ways of viewing cultures and effecting new and often vibrant syncretised and hybrid amalgamations. As a body of works, the Booker Prize has a tangential relation to this process. Nevertheless, examples of historiographic metafiction such as Moon Tiger are relevant in this context. Lively's novel follows the transition between empire and the post-modern world in which the axis of imperial "centre" has been displaced. From the authoritative representation of Englishness in the Raj novels of Scott and Farrell to the frangible "Englishness" of Ondaatje's The English Patient and the nostalgia of Ishiguro's The Remains of the Day, the lineaments of this process may be discerned.

It is argued that post-colonialism in its more self-reflexive conceptions can be seen as responsible for the diversion of attention away from global capitalism that remains the structuring principle of global relations. Late capitalism and flexible production have disorganised earlier conceptions of global relations especially those comprehended by binaries such as coloniser/colonised and First World/Third World in which the nation state is taken for granted as the political organising unit. As Dirlik argues:

The situation created by global capitalism helps explain certain phenomena that have become apparent over the last two or three decades, but epecially since the eighties: global motions of peoples (and, therefore, cultures), the weakening of boundaries (among societies, as well as among social categories), the replications in societies internally of inequalities and discrepancies once associated with colonial differences, simultaneous homogenization and fragmentation within and across societies, the interpenetration of the 
global and local, and the disorganization of the world conceived in terms of three worlds or nation states. What is ironic is that the managers of this world situation themselves concede that they (or their organizations) now have the power to appropriate the local for the global, to admit different cultures into the realm of the capital (only to break them down and remake them in accordance with the requirements of production and consumption), and even to reconstitute subjectivities across national boundaries to create producers and consumers more responsive to the operations of capital..$^{15}$

Empire is a bilateral relationship; the act of imperialism changes the colonising as well as the colonised power. The lines of trade, communication and discourse linking Great Britain to its colonies, while controlled and maintained by the agents of empire, simultaneously concealed a plethora of alternative stories told and retold along the same lines, and the stories of counter-cultures proliferated among lines within, across, and underneath the direct and "official" systems of communication, trade and exchange represented by the first. Thus, for example, the ominous spread of "chapatis" that portends the nativist uprising in The Siege of Krishnapur represents a pointed symbol of resistance to the enactors of the uprising while spreading alarm among the colonialists over their ambiguity of portent. As Ronald Robinson puts it in "The Excentric Idea of Imperialism":

... for all the initiating force of the metropolitan components in [these] economic and power relations, they produced such vastly different imperial effects in the different countries as to suggest that imperial wealth and power were generated substantially through the third set of linkages which ran from top to bottom of local political economies. In the last analysis, imperialism gathered its forces from the local collaborative systems which translated European economic and power 
inputs into multiplied indigenous outputs. The character of local collaboration and resistance, the extent of national unification, decided the balance of inequalities and so the degree of imperialism involved. ${ }^{16}$

Lines of communication and exchange within contemporary world cultures are now globally dispersed and complexly intertwined. This has inevitable consequences for nation formation and the way populations conceive the idea of "home". As Vijay Mishra puts it: "'Home' now signals a shift away from homogeneous nation-states based on an ideology of assimilation to a much more fluid and contradictory definition of nations as a multiplicity of diasporic identities." ${ }^{17}$

Imperialism rarely recognised the culture of the colonised and discouraged contact between races at the same time as it ensured markets for its trade and exchange. While in economic terms imperialism was about profit and in social terms the displacement of one people and their replacement with another, it was also a psychological construction. Imperialism was primarily a representation of the white European unto him or herself and to this extent can be seen as markedly shallow, be this reflected in the Rousseau's idea of the "noble savage", or in the Christian missionary project of bringing enlightenment, moral and epistemological advancement to the "indigenous heathen". However, from the perspective of the colonised, who may have no culturally embedded pre-existing notions of contact with others (the coloniser or imperialist) prior to colonisation, it could be argued that such a process is only recently being reciprocated in literatures written from that perspective. Hulme's the bone people, Okri's The Famished Road, Doyle's Paddy Clarke Ha Ha Ha, and Kelman's How Late It Was, How Late can be interpreted in this light among the Booker Prize winners.

The fundamental distinction to be made here is that between an understanding of postcolonialism as a means by which the descendants of the settler groups claim authenticity and autonomy and thus purge themselves of guilt by separating themselves as agents from the source culture, and an understanding of empire as a muted and ambiguous legacy among nations, ethnic groups, and individuals, in the culture after empire. Again 
the emphasis on a non-binary post-colonialism should be stressed-the looking no longer for a mythical balance between coloniser and colonised or locating culture at the nexus of the colonial and imperial exchange but rather for an understanding that cultures interact in complex ways in which a model of a more fluid interaction is appropriate. Cultures are neither strictly post-colonial or post-imperial but complex combinations of the two and rarely reduce to simplistic formulations. Multicultural Britain is composed of the descendants of a myriad of formerly colonised peoples. Being post-imperial stands at one end of a spectrum that encompasses being a Nigerian, Japanese, Indian, or Caribbean citizen of Britain. Ben Okri is Nigerian in a British context much as Albert Wendt is Samoan in a New Zealand context. In many cases living in another culture frees one to experience one's older culture more acutely. Amongst the Booker Prize winners Naipaul, Rushdie, Ishiguro, and Okri all describe their former cultures from within Britain. In this context the fast distinctions between post-colonialism and postimperialism give way to fragile, complex and hybrid identities.

Once the colonial-imperial process is entered into, however, and over time a relationship between coloniser and colonised is established, independence from the coloniser is inevitably compromised if one shares the same habits and means of expression as the coloniser, if not the same customs. The act of reclaiming indigeneity "damaged" by the process of colonisation, reinscribes indigeneity in changed, even hybrid, terms. Hybridity is one theme shared by Hulme's the bone people, Ondaatje's The English Patient, Rushdie's Midnight's Children and the magic- realist world of Olcri's The Famished Road. In each of these novels new identities arise from the intersection of cultures.

The climate after empire now proceeds in the negotiation of cultural identities with complex forms of corporate neo-imperialism and corresponding resistances to and complicities with them. This process rather than having a single, unitary imperative is multiple and globally diffuse. As Johannes Fabian puts it: 
A persistent myth shared by imperialists and many (Western) critics of imperialism alike has been that of a single decisive conquista, occupation, or establishment of colonial power, a myth which has its complement in similar notions of sudden decolonization and accession to independence. Both have worked against giving proper theoretical importance to overwhelming evidence for repeated acts of oppression, campaigns of pacification, and suppressions of rebellions, no matter whether these were carried out by military means, by religious and educational indoctrination, by administrative measures, or, as is more common now, by intricate monetary and economic manipulations under the cover of foreign aid. The ideological function of schemes promoting progress, advancement, and development has been to hide the temporal contingency of imperialist expansion. ${ }^{18}$

In such a context the concept of the indigenous or "native" is ascribed a temporal loading of the "primitive past" and this qualifies as justification for imperial intervention in the indigenous culture in the name of progress. This is a process which The Famished Road addresses.

As a prize for a novel written in English, the Booker is a measure of the porousness and assimilative strength of English language as an agent of cultural exchange that is currently engaged in negotiating identities beyond the binarisms of "English" and "Other", "coloniser" and "colonised". The Prize represents a British Commonwealth notion of literary response following empire. Now to be understood more in terms of an "empire of language" than of political and economic amalgamation, this empire is no longer the empire of Victorian England, nor the post-war Commonwealth of Nations. In their place are a multifarious and often hybridised group of nations or national entities, assimilated under the common aegis of written and spoken English, which articulate and negotiate the changing nature of culture and influence over the perception of other identities, which, in turn, historically have variously had their otherness defined in the 
context of a British imperial influence. There remains, however, a force of linguistic imperialism in the triumph of English over indigenous languages.

Empire was never only about British cultural dominance of its imperial subjugates, although this of course was its most conspicuous result; it also can be read as an admission of British cultural anxieties. Caribbean novelist and essayist Wilson Harris questions whether in fact the "Other" exists, and he questions the priority it is given within the field of post-colonial discourse in view of the universality with which it is invoked:

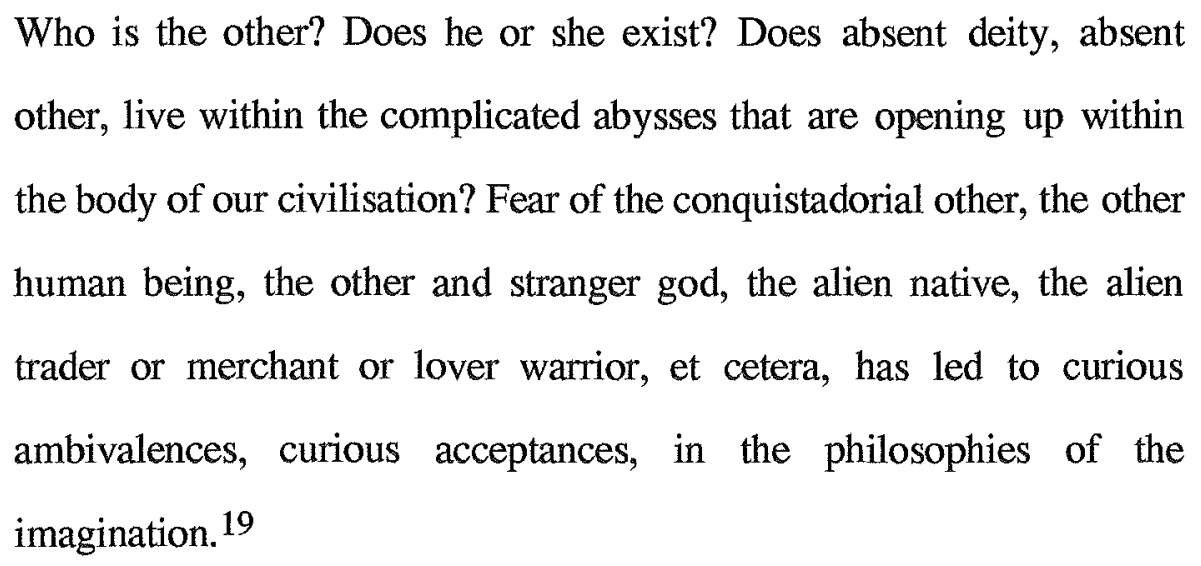

While Harris is opposed to the notion of a pure or essential culture (the loss of which is at the heart, for example, of V.S. Naipaul's post-colonial nihilism) and affirms the desire for cultural complexities, he remains ambivalent about the possibilities of identity that follow from imperialism. In the climate of post-imperial cultural relativism we are all and none of us "Others".

Over this twenty-six-year period of the Booker Prize numerous novels have articulated the concept of alteria as a feature of empire - from the culture of insanity in Rubens' The Elected Member, to the encroachment of the colonial on the African village world of Azaro in Okri's The Famished Road, and to the enigmatic identity of the burned "English" patient of Ondaatje's The English Patient. In the culture of empire, contact with the "foreign", the "Other" and even the "savage", perversely was contact with a part of the self, part of the often unacknowledged and displaced sense of "foreignness" in the 
self. As Julia Kristeva puts it, "we are foreigners to ourselves. . . "20 The degree to which this part of the self was suppressed, fostered or given means of expression is a reflection also of the success of empire in terms of its ability to exercise a positive influence over the colonised.

A nationalist phase among English speaking nations has now evolved into an expression of various indigeneities within the scattered diaspora as well as the return to mythical roots as markers of cultural revivals. In settler-invader nations such as New Zealand, Australia, and Canada, for example, the process of forming newly defined nationalisms frequently takes place at the forefront of the national consciousness. The novels from these countries which have won the Booker Prize characteristically reflect uneasy pasts, fragmentary identities and a sense of self variously struggling to come to terms with identity and meaning in a national culture.

Keri Hulme's the bone people concerns the uneasy relationship between Maori and Pakeha New Zealand. Hulme's novel explores the links between indigenous mythology and "imported" Celtic mythology, racial purity and hybridity, personified by the makeshift "family" of Joe, Kerewin and Simon and their attempts to provide one another with a kind of solace and cohesion that they lack as individuals and when apart. They are "love's wounded beings" as Anna Smith has put it, echoing in contemporary terms a potentially redemptive vision for the allegorical notion of cultural "slippage" in the colonial-imperial condition identified by Hugh Ridley and Sara Suleri. ${ }^{21}$

This "slippage" and contrapuntal negotiation of cultural identity is evident in a number of the Booker Prize winning novels. For example, Peter Carey's Australian colonial dystopia, Oscar and Lucinda, in parodic form narrates the folly of early colonial pretensions of building a "new England" in the unruly Australian outback. Schindler's Ark blurs the boundaries between fiction and fact, and through the character of the antiauthoritarian Oskar Schindler, explores contrapuntally the notion of the Australian psyche as portrayed through the actions of the flamboyant industrialist and "random-saviour" in Hitler's wartime extermination programme. Keneally's character is "Australianised" without any direct reference to Australia. The English Patient explores the fragmentation 
of identities and blurring of cultural boundaries at the close of the Second World War. It anticipates the interweaving of cultures and global restructuring that follows the aftermath of war, and through the enigmatic identity of the burned "English patient" explores the uncertainty and dissolution of stable narrative that characterises the shift from the modern to the post-modern worlds.

The Booker Prize, which focuses attention on novels from throughout the Commonwealth, more perhaps than any other current literary institution, offers for appreciation novels which reflect the process of comparing and contrasting the literatures of English-speaking nations both within an historical context and with a view to contemporary developments. Succeeding the novels of the Raj and those describing imperial expansion are novels such as Lively's Moon Tiger, Ondaatje's The English Patient, and Ishiguro's The Remains of the Day which demonstrate ways in which postwar culture has evolved from the loss of empire. Storey's Saville, Murdoch's The Sea, The Sea, and Newby's Something To Answer For in differing ways describe British insularity and the dissolution of empire. Rushdie's Midnight's Children traces the decolonising process from British rule in India to national independence from the different, but no longer neatly "opposing" perspective, of the subaltern. Hulme, Carey and Keneally explore the myths, legends and personas of an antipodean sensibility. Doyle, Kelman, and even Amis point to the uneasy federalism of the new Britain.

All these novels assembled under the rubric of "Booker Prize winners" suggest that literature in the latter half of the twentieth-century is not merely a vast dispersion of literary forces, trends and movements but also a process of negotiation by individual writers of the changing relations among nations, tribes, and cultures in the aftermath of empire. 


\section{Notes}

${ }^{1}$ Edward Said, "Introduction", Culture and Imperialism (London: Vintage, 1994). The discussion here is in general terms.

${ }^{2}$ Rob Wilson and Wimal Dissanaynke, eds., Cultural Production and the Transnational Imagery (Durham; London: Duke University Press, 1996), p. 2.

${ }^{3}$ Mark Williams, "Looking Sideways: English Studies, Tradition, and Cross-Cultural Comparisons", SPAN 28 (1989), p. 23.

${ }^{4}$ Brennan, Salman Rushdie and The Third World: Myths of Nation (London: Macmillan, 1989), p. x.

${ }^{5}$ Iain Sharp, "Interview with Les Murray", Landfall 166, 48:2 (1988), p. 160.

${ }^{6}$ Brennan, Salman Rushdie and The Third World, p. 11.

${ }^{7}$ Brennan, Salman Rushdie and The Third World, p. 11.

${ }^{8}$ Brennan, Salman Rushdie and The Third World, p. 6.

${ }^{9}$ Rushdie, "The Empire Writes Back With a Vengeance", The Times 3 July 1982, p. 8.

10 David Sanders, Losing an Empire, Finding a Role: British Foreign Policy Since $1 \overline{9} 4 \overline{5}$ (London: Macmillan, 1990), p. 131.

${ }^{1}$ Catherine Hall, "Histories, Empires and the Post-colonial Moment", in The PostColonial Question: Common Skies, Divided Horizons, eds., Iain Chambers and Lidia Curti (London: New York: Routledge, 1996), p.67.

${ }^{12}$ Arif Dirlik, "The Postcolonial Aura: Third World Criticism in the Age of Global Capitalism", in Contemporary Postcolonial Theory, ed., Padmini Mongia (London: Arnold, 1997), p. 297.

133ames Clifford, The Predicament of Culture (Massachusetts: Harvard University Press, 1988). The discussion here is in general terms.

14James Clifford, "The Global Issue: A Symposium", Art In America. 77:7 (1989), p. 87.

${ }^{15}$ Arf Dirlik, "The Postcolonial Aura: Third World Criticism in the Age of Global Capitalism"i, p. 311. 
${ }^{16}$ Ronald Robinson, "The Excentric Idea of Imperialism, with or without Empire", Imperialism and After: Continuities and Discontinuities, Ed., Wolfgang J. Mommsen \& Jurgen Osterhammel (London: Allen \& Unwin, 1986), p. 282.

${ }^{17}$ Vijay Mishra, "Postcolonial Differend: Diasporic Narratives of Salman Rushdie", Ariel 26:3 (1995), p. 7.

${ }^{18} \mathrm{~J}$ ohannes Fabian, Time and the Other. How Anthropology Makes its Object (New York: Columbia University Press, 1983), p. 149.

${ }^{19}$ Wilson Harris, "The Fabric of the Imagination", From Commonwealth to Postcolonial, ed. Anna Rutherford (Coventry: Dungaroo Press, 1992), p. 19.

${ }^{20}$ Julia Kristeva, Strangers To Ourselves, trans. Leon S. Roudiez (New York: Columbia University Press, 1991), p. 170.

${ }^{21}$ Anna Smith, "Love's Wounded Beings", in Opening the Book, eds., Mark Williams and Michelle Leggot (Auckland: Auckland University Press, 1994), p. 140. 


\section{Bibliography}

Ackroyd, Peter. Notes For a New Culture. London: Alkin Books, 1993.

Afzal-Khan, Fawzia. Cultural Imperialism and the Indo-English Novel. Pennsylvania:

The Pennsylvania State University Press, 1993.

Amis, Kingsley. The Old Devils. London: Penguin, 1986.

Arvidson, Ken. "Aspects of Contemporary Maori Writing in English." In Graham

McGregor and Mark Williams. Eds. Dirty Silence: Aspects of Language and Literature in New Zealand: Essays Arising from the University of Waikato Winter Lecture Series of 1990. Auckland: Oxford University Press, 1991.

Ashcroft, Bill, and Gareth Griffiths, and Helen Tiffin. The Empire Writes Back. Theory and Practice in Post-Colonial Literatures. London \& New York: Routledge, 1993.

Ashcroft, Bill. "Interpolation and Post-colonial Agency." New Literatures Review, 28/29, (Winter 1994 - Summer 1995), pp. 176-189.

Atwell, David. J.M Coetzee:South Africa and the Politics of Writing. Berkely: University of California Press: 1993.

Auerbach, Erich. Mimesis: The Representation of Reality in Western Literature. Trans. Willard R. Track. Princeton: Princeton University Press, 1953.

Barker, Pat. The Ghost Road. London: Viking, 1995.

Barnes, Julian. Flaubert's Parrot. London: Jonathan Cape, 1984.

Barthes, Roland. S / Z. Trans. Richard. Miller. Pref. Richard Howard. New York: Hill \& Wang 1974.

Barthes, Roland. Image, Music, Text. Ed. Stephen Heath. New York: Hill \& Wang, 1977.

Baudrillard, Jean. America. Trans. Chris Turner. London: Verso, 1993.

Baxter, Gisele. M. "Clothes, Men and Books: Cultural Experiences and Identity in the Early Novels of Anita Brookner", English 42:173 (1993), p. 126.

Berger, John. G. A Novel. London: Weidenfeld \& Nicolson, 1972. 
Berndt, Ronald and Catherine. The World of the First Australians. Aboriginal Traditional Life: Past and Present. Canberra: Aboriginal Studies Press, 1988.

Bhabha, Homi K. The Location of Culture. London: Routledge, 1994.

Billington, Rosamund, Sheelagh Strawbridge, Lenore Greensides, Annette Fitzsimons. eds. Culture and Society. London: Macmillan, 1991.

Blackwell, Michael. Clinging To Grandeur: British Attitudes and Foreign Policy in the Aftermath of the Second World War. London: Greenwood Press, 1993.

Bolger, Dermot. Internal Exiles. Poems. Portlaoise: The Dolmen Press, 1986.

Bolger, Dermot. Night Shift. London: Penguin, 1993.

Bolger, Dermot. Ed. The Picador Book Of Contemporary Irish Fiction. London: Picador, 1994.

Boyers, Robert. Atrocity and Amnesia: The Political Novel since 1945. Oxford: Oxford University Press, 1985.

Bradford, Richard. Kingsley Amis. New York: Edward Arnold, 1989.

Brennan, Timothy. Salman Rushdie and The Third World: Myths of Nation. London: Macmillan, 1989.

Brink, Andre. Rumours of Rain. London: W.H. Allen, 1987.

Brookner, Anita. Hotel du Lac. London: Triad/Panther, 1984.

Brown, Ruth. "English Heritage and Australian Culture: The Church and Literature of England in Oscar and Lucinda." Australian Literary Studies, 17:2, (1995), pp. 135140.

Byatt, A.S. Possession. A Romance. London: Vintage, 1991.

Calinescue, Martei. Five Faces of Modernity. Durham: Duke University Press, 1987.

Carey, Peter. Oscar and Lucinda. Queensland: University of Queensland Press, 1988.

Cesaire, Aime. Discourse on Colonialism. Trans. Joan Pinkam. New York: Monthly Review Press, 1972.

Chambers, Iain and Lidia Curti. Eds.The Post-Colonial Question: Common Skies, Divided Horizons. London: Routledge, 1996. 
Chandy, Amil. Magical Realism and The Fantastic: Resolved Versus Unresolved Autonomy. New York: Garland, 1985.

Clifford, James. The Predicament of Culture. Cambridge, Massachusetts: Harvard University Press, 1988.

Clifford, James. "The Global Issue: A Symposium." Art in America, 77:7 (1989), pp. 86-87.

Coetzee, J. M. Life \& Times of Michael K. London: Penguin, 1985.

Coetzee, J.M. Intro. White Writing. On the Culture and Letters of South Africa. New York: Yale University Press, 1988.

Craig, Cairns. Out of History: Narrative Paradigms in Scottish and British Culture. Edinburgh: Polygon, 1996.

Crane, Ralph. "Ruth Prawer Jhabvala's Sky: Escape from the Heat and Dust?". SPAN, 24 (1987), pp. 178-189.

Cronin, Richard. "The Hill of Devi and Heat and Dust" Essays in Criticism, 36:2 (1986), pp. 142-159.

Cudjoe, Selwyn. R. V. S. Naipaul. A Materialist Reading. Amherst: University of Massachusetts Press, 1988.

Davis, Phillip. "'Einstein in the Patent Office": Stanley Middleton at 70". Encounter, 73 (1989), pp. 57-63.

Deane, Seamus. Intro. Nationalism, Colonialism and Literature. Minnesota: University of Minnesota, 1990.

Dening, Greg. Mr Bligh's Bad Language: Passion, Power, and Theatre on the Bounty. Cambridge, England; New York: Cambridge University Press, 1992.

Derrida, Jacques. Of Grammatology. Trans. Gayatri Chakravorty Spivak. Baltimore: Johns Hopkins University Press, 1976.

Dixon, Norman. On the Psychology of Military Incompetence. London: Jonathan Cape, 1978. 
Docherty, Thomas. "Postmodern Characterization: The Ethics of Alterity." In Edmund J. Smyth. Ed. Postmodernism and Contemporary Fiction. London: Batsford, 1991, pp. 169-188.

Doyle, Roddy. The Commitments. London: Minerva, 1992.

Doyle, Roddy. Paddy Clarke Ha Ha Ha. London: Secker \& Warburg, 1993.

Elton, Geoffrey. The English. Oxford: Blackwell, 1992.

Everett, Barbara. "Kingsley Amis: Devils and Others." In Dale Salwark, Ed. Kingsley Amis in Life and Letters. New York: St. Martin's Press, 1991, pp. 89-99.

Ezekiel, Nissim. "Two Readers and Their Texts." In Guy Amirthanayagam. Ed. Asian and Western Writers in Dialogue: New Cultural Identities. London: Macmillan, 1982, pp. 137-141.

Farrell, J.G. The Siege of Krishnapur. London: Flamingo, 1985.

Fee, Margery. "Why C.K. Stead Didn't Like Keri Hulme's the bone people: Who Can Write as Other?" Australian and New Zealand Studies in Canada. 1. 1989, pp. 11-32. Ferro, Mark. Colonization: A Global History. London: Routledge, 1997.

Fitzgerald, Penelope. Offshore. London: Viking, 1993.

Forster, E.M. A Passage To India. Intro. Peter Burra. London: J.M. Dent, 1942.

Foucault, Michael. Archeology of Knowledge. Trans. A. M. Sheridan Smith. London: Tavistock, 1972.

Foucault, Michael. Power/Knowledge: Selected Interviews and Other Writings, 1972, 1977, Foucault, Michael. Ed. and Trans. by Colin Gordon [et al]. Brighton: Harvester Press, 1980.

Fuller, John. Flying to Nowhere. Hammondsworth: Penguin, 1983.

Frazer, James George. The Golden Bough. A Study in Magic and Religion. London: Macmillan, 1925.

Gallagher, Susan Vanzanten. A Story of South Africa. J.M. Coetzee's Fiction in Context. Cambridge, Massachusetts: Harvard University Press, 1991.

Gandhi, Leela. Postcolonial Theory: A Critical Introduction. St. Leonards: Allen \& Unwin, 1998. 
Gates, Henri-Louis. The Signifying Monkey. A Theory of African-American Literary Criticism. New York: Oxford University Press, 1988.

Gide, Andre. Travels in the Congo. Trans. Dorothy Bussy. London: Penguin, 1986.

Gilbert, Elliot L. "'No Originals, Only Copies': Pre-Raphaelite Images of Belatedness and Innovation." Victorian Newsletter. 81 (1992), pp.1-5.

Goff, Martyn. Ed. Prize Writing: An Original Collection of Writings by Past Winners to Celebrate 21 Years of The Booker Prize. London: Hodder \& Stoughton, 1989.

Golding, William. Rites of Passage. London: Faber \& Faber, 1982.

Goodwin, Ken. "Is a Commonwealth Literary History Possible?" SPAN 21 (1985), pp. 9-28.

Gooneratne, Yasmine. "Paul Scott's Staying On: Finale in a Minor Key," The Journal of Indian Writing in English 9:2 (1981), pp. 1-12.

Gorak, Irene. "Libertine Pastoral: Nadine Gordimer's The Conservationist." Novel 24:3 (1991), pp. 241-256.

Gordimer, Nadine. The Conservationist. New York: Penguin, 1978.

Gray, Stephen. "An Interview with Nadine Gordimer." Contemporary Literature, 22:3 (1981), pp.263-271.

Griffiths, M. "Great English Houses/New Homes in England?: Memory and Identity in Kazuo Ishiguro's The Remains of the Day and V.S. Naipaul's The Enigma of Arrival." SPAN 2 (1993), pp. 488-503.

Hardy, Barbara. "A Cinderella's Loneliness." Times Literary Supplement. 14 September, 1984. p. 1019.

Harris, Wilson. "The Fabric of the Imagination". In Anna Rutherford. Ed. From Commonwealth to Post-colonial. Coventry: Dungaroo Press, 1992.

Harrison, James. Salman Rushdie. New York: Twayne, 1992.

Harvett, Lars. "The Imprint of Recorded Events in the Narrative Form of J. G. Farrell's The Siege of Krishnapur." English Studies, 74:5 (1993), pp. 451-69.

Hassall, Anthony. Dancing on Hot Macadam: Peter Carey's Fiction. St. Lucia, Queensland: University of Queensland Press, 1994. 
Heighton, Stephen. "Approaching 'That Perfect Edge': Kenetic Techniques in the Poetry and Fiction of Michael Ondaatje." Studies in Canadian Literature, 13:2 (1988), pp. 223-243.

Heller, Agnes. Can Modernity Survive? Berkeley and Los Angeles: University of California Press, 1990.

Hewson, Kelly. "Making the 'Revolutionary Gesture': Nadine Gordimer, J.M. Coetzee and Some Variations on the Writer's Responsibility." Ariel, 19:4 (1988), pp. 55-72.

Hollinger, Robert. Postmodernism and the Social Sciences: a Thematic Approach. Thousand Oaks, California: Sage, 1994.

Hollington, Michael. "The Ned Kelly of Cracow." Meanjin. 42:1 (1983), pp. 42-46.

Huggan, Graham, "Is The (Gunter) Grass Greener On The Other Side? Oscar And Lucinda In The New World." World Literature Written in English, 30.1 (1990), pp.1-10.

Huggan, Graham, and Stephen Watson. Eds. Critical Perspectives on J.M. Coetzee. London: Macmillan, 1996.

Hughes, Robert. The Fatal Shore. London: Collins Harvill, 1987.

Hulme, Keri. the bone people. London: Picador, 1994.

Hulme, Peter. Colonial Encounters. Europe and the Native Caribbean 1493-1797. London: Methuen, 1986.

Hutchings, W. Ed. David Storey. A Casebook. New York: Garland, 1992.

Ishiguro, Kazuo. Remains of the Day. London: Faber \& Faber, 1990.

Jhabvala, Ruth Prawer. Heat and Dust. London: Penguin, 1994.

Johansen, Ib. "The Flight from the Enchanter. Reflections on Salmon Rushdie's Grimus." Kunapipi 7:1 (1985), pp. 20-33.

Johnstone, Richard. "The Rise of Faction." Quadrant, 29:4 (1985), pp. 76-78.

Johnston, Ross. W. Great Britain Great Empire: An Evaluation of the British Imperial Experience. St Lucia: University of Queensland Press, 1981.

Jones, Gareth Elwyn. Modern Wales: A Concise History c.1485-1979. Melbourne: Cambridge University Press, 1984. 
Keating, Michael. Nations Against the State. The New Politics of Nationalism in Quebec, Catalonia \& Scotland. London: Macmillan, 1996.

Kelman, James. Some Recent Attacks. Essays Cultural \& Political. Balmoral: AK Press, 1992.

Kelman, James. How Late It Was, How Late. London: Secker \& Warburg, 1994.

Keneally, Thomas. Schindler's Ark. London: Coronet, 1983.

Kiernan, V.G. Imperialism and Its Contradictions. Ed. \& Intro. Harvey J. Kaye. London and New York: Routledge, 1995.

King, Bruce. V. S. Naipaul. New York: Macmillan, 1993.

King, Anthony. Ed. Culture, Globalization and the World-System. London: Macmillan, 1991.

King, Bruce. Ed. Literatures of the World in English. London: Routledge \& Kegan Paul, 1974.

Kipling, Rudyard. Selected Poems. Ed. Peter Keating. London: Penguin, 1993.

Kossick, Shirley. "The Novels of Bernice Rubens: 1960-1992," Unisa English Studies, $31: 2$ (1993), pp. 34-40.

Kristeva, Julia. Strangers To Ourselves. Trans. Leon S. Roudiez. New York: Columbia University Press, 1991.

Kureishi, Hanif. London Kills Me. 3 Screenplays and 4 Essays. Penguin: New York, 1992.

Lamb, Jonathan. "A Sublime Moment off Poverty Bay." In G. McGregor \& M. Williams. Eds. Dirty Silence. Aspects of Language and Literature in New Zealand. Auckland: Oxford University Press, 1991. pp. 97-116.

Leggott, Michele. Dia. Auckland: Auckland University Press, 1994.

Levi, Primo. The Mirror Maker. Stories and Essays. Trans. Raymond Rosenthal. New York: Shocken Books, 1989.

Lively, Penelope. The Road to Lichfield. London: Heinemann, 1977.

Lively, Penelope. Moon Tiger. London: Penguin, 1987. 
Lyon, Peter. "The Commonwealth and the Suez Crisis." In R. Louis and R. Owen. Eds. Suez 1956. The Crisis and its Consequences. Oxford: Oxford University Press, 1989. pp. $257-274$.

Lucas, John. England and Englishness: Ideas of Nationhood in English Poetry 16881900. (Iowa: University of Iowa Press, 1990.

Maja-Pearce, Adewale. "The Naipauls on Africa: An African View." The Journal of Commonwealth Literature, 20:1 (1985), pp. 111-117.

Macaskill, Brian. "Interrupting the Hegemonic: Textual Critique and Mythological Recuperation from the White Margins of South African Writing." Novel, $23: 2$ (1990), pp. 156-181.

McDiarmid, Hugh. Selected Poetry. Alan Riach \& Michael Grieve. Eds. Exeter: Carcanet, 1992.

Maxwell, Anne. "Revisionist Histories and Settler Colonial Societies". Southern Review, 27:4 (1994), pp. 383-402

McMahon, Joseph H. "Marxist Fictions: The Novels of John Berger." Contemporary Literature, 23:2 (1982), pp. 202-224.

McNeil, Elton B. The Psychoses. Englewood Cliffs, New Jersey: Prentice-Hall, 1970.

Maxwell, Ann. "Revisionist Histories and Settler Colonial Societies." Southern Review, 27:4 (1994), pp. 383-401.

Middleton, Stanley. Holiday. London: Penguin, 1974.

Mill, John Stuart. "Chapter V. A Crisis in Mental History. One Stage Onward." Autobiography. New York: Columbia University Press, 1960. pp. 132-183.

Miller, David. On Nationality. New York: Oxford University Press, 1995.

Miller, James. Koori: A Will To Win. The Heroic Resistance Survival and Triumph of Black Australia. London: Angus \& Robertson, 1986.

Mo, Timothy. Sour Sweet. London: Hodder \& Stoughton, 1990.

Mongia, Padmini. Ed. Contemporary Postcolonial Theory: A Reader. London: Arnold, 1996. 
Morgan, Edwin. "Glasgow Speech in Recent Scottish Literature." Crossing The Border. Manchester: Carcanet, 1990. pp. 312-330.

Murdoch, Iris. The Sea, The Sea. Frogmore: Triad / Panther Books, 1980.

Murray, Stuart. Ed. Not On Any Map. Exeter: University of Exeter Press, 1997.

Naipaul, V.S. In A Free State. London: Andre Deutsch, 1972.

Naipaul, V.S. India: A Wounded Civilization. New York: Knopf, 1977.

Naipaul, V.S. A Bend in the River. London: Deutsch, 1979.

Nayder, Lillian. "Agents of Empire in The Woman in White." The Victorian Newsletter, 83 (1993), pp. 1-7.

Neich, Roger. Painted Histories: Early Maori Figurative Painting. Auckland: Auckland University Press, 1993.

Nelson, William. "The Grotesque in Darkness Visible and Rites of Passage." Twentieth Century Literature, 28:2 (1982), pp. 181-194.

Newby, P.H. Something to Answer For. Guernsey: Palm Books, 1993.

Newman, Judie. "Gordimer's The Conservationist: "That Book of Unknown Signs." Critique, 22:3 (1981), pp. 31-44.

Newman, Judie. The Ballistic Bard. Postcolonial Fictions. London: Arnold, 1995.

Nightingale, Peggy. Journey Through Darkness. The Writing of. V. S. Naipaul. Queensland, University of Queensland Press, 1987.

Nixon, Rob. London Calling: V.S. Naipaul Postcolonial Madarin. New York: Oxford University Press, 1992.

O'Toole, Fintan. Intro. A Dublin Quartet by Dermot Bolger. London: Penguin, 1992.

Okri, Ben. The Famished Road. London: Vintage, 1992.

Okri, Ben. Songs of Enchantment. New York: Nan. A. Talese, 1993.

Ondaatje, Michael. In The Skin of a Lion. London: Picador, 1988.

Ondaatje, Michael.The English Patient. London: Picador, 1992.

Owen, Wilfred. "Anthem for Doomed Youth." Collected Poems. London: Chatto \& Windus, 1963. 
Penner, Dick. Countries of the Mind. The Fiction of J.M. Coetzee. Westport, Connecticut, Greenwood Press, 1989.

Petterson, Rose. Nadine Gordimer's One Story of a State Apart. Stockholm: Uppsala Univeristy Press, 1995.

Petersson, Irmtraud. "'White Ravens' in a World of Violence: German Connections in Thomas Keneally's Fiction." Australian Literary Studies, 14:2 (1989), pp. 160-173. Pipes, Daniel. The Rushdie Affair: The Novel, the Ayatollah, and the West. New York: Carol, 1990.

Porter, Roy. Ed. Myths of English. Cambridge: Polity Press, 1992.

Priebe, Richard. Myth, Realism and the West African Writer. Trenton, N.J.: Africa World Press, 1988.

Rajan, Gita and Radhika Mohanram. Eds. Postcolonial Discourse and Changing Cultural Contexts. Westport, Connecticut: Greenwood Press, 1995.

Ramanathan, Suguna. Iris Murdoch. Figures of Good. London: Macmillan, 1990.

Rao, Krishna A.V. "History and the Art of Fiction: J. G. Farrell's Example: The Siege of Krishnapur. " The Literary Criterion. 23:3 (1988), pp. 38-47.

Raschke, Deborah. "Penelope Lively's 'Moon Tiger': Re-envisioning a 'history of the world.'" Ariel, 26:4 (1995), pp. 115-132.

Reinelt, Janet. "Storey's Novels and Plays: Fragile Fictions." In William Hutching. Ed. David Storey a Casebook. New York: Garland, 1992. pp. 53-72.

Ridley, Hugh. Images of Imperial Rule. London: Croom Helm, 1983.

Robinson, Ronald. "The Excentric Idea of Imperialism, with or without Empire." In Wolfgang Mommsen and Jurgen Osterhammel. Eds. Imperialism and After Continuities and Discontinuities. London: Allen \& Unwin, 1986.

Rosenau, Pauline. Post-Modernism and the Social Sciences: Insights, Inroads, and Intrusions. Princeton: Princeton University Press, 1992.

Rossetti, Christina. Poems of Christina Rossetti. William M. Rossetti. Ed. New York: The Macmillan Company, 1904. 
Rossetti, Dante Gabriel. Poems by Dante Gabriel Rossetti. Vol 2. Elizabeth Luther Cary. Ed. New York: The Knickerbocker Press, 1903.

Rubin, David. "Ruth Jhabvala In India", Modern Fiction Studies. 30:4 (1984), pp. 669683.

Rubin, David. After The Raj: British Novels of India Since 1947. Hanover: University Press of New England, 1986.

Rubens, Bernice. The Elected Member. London: Hamish Hamilton, 1983.

Rushdie. Salman. Midnight's Children. London: Picador, 1982.

Rushdie, Salman. Shame. London: Jonathan Cape, 1983.

Rushdie, Salman. Imaginary Homelands. New York: Penguin, 1991.

Sanders, David. Losing an Empire Finding a Role. British Foreign Policy since 1945. London: Macmillan, 1990.

Sahib, Geetha Ganapathy-Dore. "The Novel of the Nowhere Man: Michael Ondaatje's The English Patient." Commonwealth Essays and Studies. 16:2 (1993), pp. 96-100.

Said, Edward. Orientalism. London: Routledge \& Kegan Paul, 1978.

Said, Edward. Culture and Imperialism. New York: Alfred A. Knopf, 1993.

Salwak, Dale. Kingsley Amis: Modern Novelist. Maryland: Barnes \& Noble, 1992.

Sartre, Jean-Paul. "Materialism and Revolution." Literary and Philosophical Essays. New York: Macmillan, 1967.

Sartre, Jean-Paul. "Orphee noir." In L. Senghor. Ed. Anthologie de la ouvelle poesie negre et malgache de la langue francais. Paris: Presses Universitaires de France, 1972.

Sealy, I. Allan. The Trotter-Nama: A Chronicle. New York: Knopf, 1988.

Scott, Paul. Staying On. London: Panther, 1978.

Shelley, Mary. Frankenstein. London: J.M. Dent, 1960.

Slemon, Stephen and Helen Tiffin. After Europe. Sydney: Dangaroo Press, 1992.

Soyinka, Wole. Art, Dialogue \& Outrage: Essays in Literature and Culture. Isadan: New Horn Press, 1988. 
Stape, J.H. "Fiction in the Wild, Modern Manner": Metanarrative Gesture in William Golding's To the End of the Earth Trilogy." Twentieth Century Literature. 38:2, pp. 226-239.

Stead, C. K. "Keri Hulme's 'The Bone People' and the Pegasus Award for Maori Literature." Ariel. 16:4 (1985), pp. 101-106.

Stead, C.K. Answering To The Language. Essays on Modern Writers. Auckland: Auckland University Press, 1989.

Stead, C. K. The Singing Whakapapa. Auckland: Penguin, 1994.

Stokes, E. The Political Ideas of English Imperialism. London: Oxford University Press, 1960.

Storey, David. Saville. London: Jonathan Cape, 1993.

Suleri, Sarah. The Rhetoric of English India. Chicago: University of Chicago Press, 1992.

Taylor, J.R. David Storey. Edinburgh: Longman, 1974.

Tedesco, Janis. "Staying On: The Final Connection." Western Humanities Review. 39: 3. 1985. pp. 195-211.

Thomas, Dylan. Dylan Thomas: The Poems. Daniel Jones. Ed. London: J.M. Dent, 1978.

Tiffin, Helen. "V.S. Naipaul's 'Outposts of Progress'". World Literatures Written in English. 22:2 (1983), pp. 309-319.

Todd, Richard. Consuming Fictions: The Booker Prize and Fiction in Britain Today. London: Bloomsbury, 1996.

Totuola, Amos. The Palm Wine Drinkard: And His Dead Palm-Wine Tapster in the Dead's Town. London: Faber, 1961.

Tucker, Lyndsey. "Released From Bands: Iris Murdoch's Two Prosperos in The Sea, The Sea." Contemporary Literature. 27:3 (1986), pp. 378-395.

Unsworth, Barry. Sacred Hunger. London: Penguin, 1992.

Van Gennep, Arnold. The Rites of Passage. Trans. Monika B. Vizedom and Gabrielle L. Caffee. Chicago: University of Chicago Press, 1972. 
Viswanathan, Gauri. Masks of Conquest. Literary Study and British Rule in India. London: Faber and Faber, 1989.

Wall, Kathleen. "The Remains of the Day And Its Challenges to Theories of Unreliable Narration." The Journal of Narrative Technique. 24:1 (1994), pp. 18-42

Watson, Stephen. "Colonialism and the Novels of J. M. Coetzee." Research in African Literatures. 17:3 (1986), pp. 370-392.

Waugh, Patricia. Feminine Fictions. Revisiting the Postmodern. London: New York: Routledge, 1989.

Waugh, Evelyn. Decline and Fall. London: Penguin, 1953.

Waugh, Evelyn. A Handfall of Dust. London: Penguin, 1955.

West, Shearer. Ed. The Victorians and Race. Aldershot: Scolar Press, 1997.

White, Jonathan. Ed. Recasting the World: Writing After Colonisation. Baltimore: Johns Hopkins University Press, 1993.

White, Richard. Intro. Inventing Australia. Sydney: George Allen \& Unwin, 1981.

Williams, Haydn M. "Mad Seekers, Doomed Lovers, and Cemeteries in India: On R.P. Jhabvala's Heat and Dust and A New Dominion." New Literature Review. 15 (1988), pp. 11-20.

Williams, Mark. "Looking Sideways: English Studies, Tradition, and Cross-Cultural Comparisons." SPAN 28 (1989), pp. 22-39.

Williams, Mark. "C.K. Stead and The New Literary Order." Meanjin. 53:4 (1994), pp. 695-703.

Williams, Mark and Michele Leggott. Eds. Opening The Book: New Essays on New Zealand Writing. Auckland: Auckland University Press, 1995.

Williams, Raymond. The Country and the City. London: The Hogarth Press, 1993.

Wright, Derek. "Black Earth, White Myth: Coetzee's Michael K." Modern Fiction Studies. 38:2 (1992), pp. 435-444.

Young, Robert. Colonial Desire: Hybridity in Theory, Culture and Race. New York: Routledge, 1995. 
Zamora, Lois Parkinson \& Wendy B. Farris. Eds. Magical Realism: Theory, History, Community. Durham: Duke University Press, 1995. 